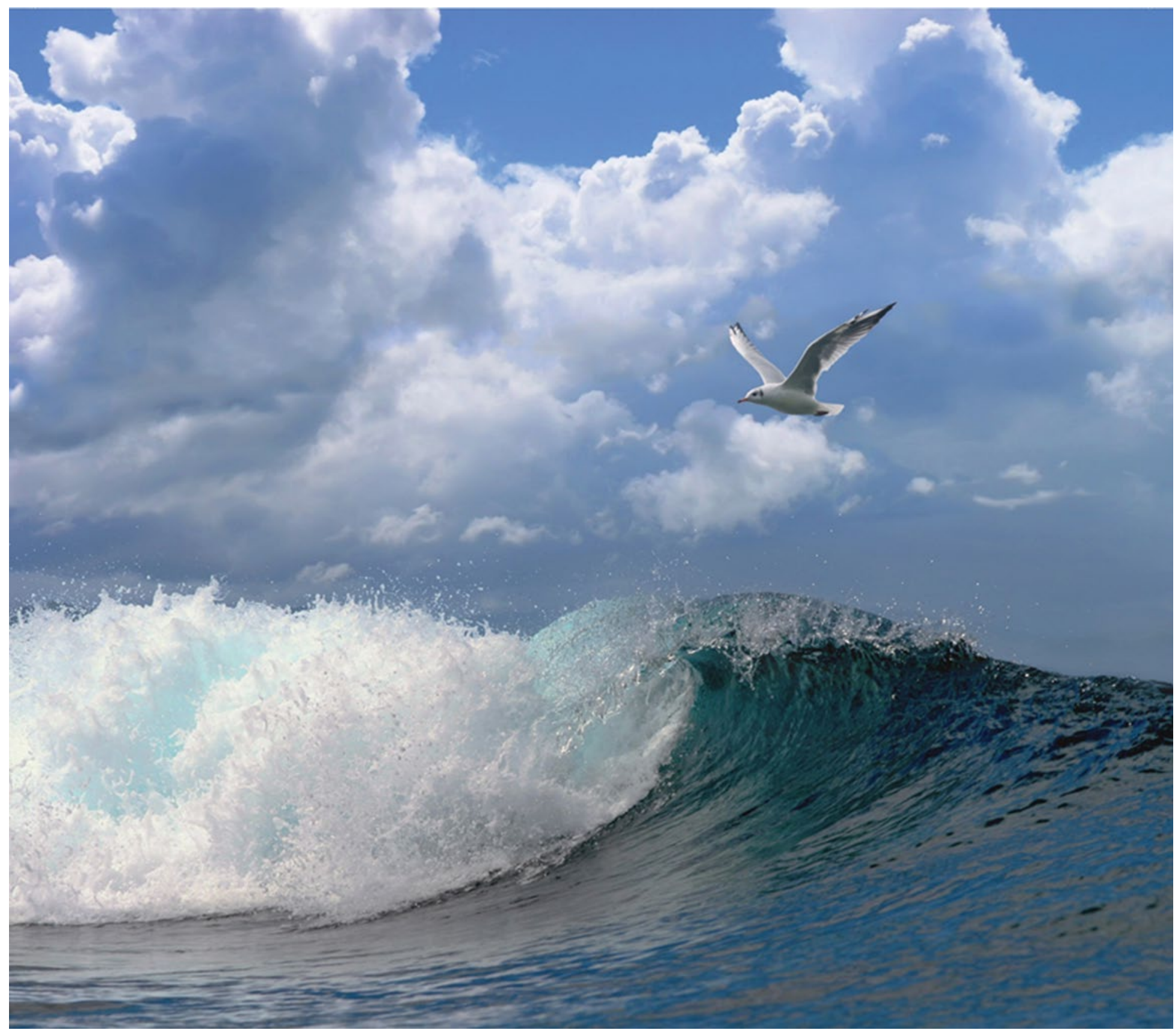

\title{
NatuurBalans Noordzee
}

Voorbeeld uitwerking van een Noordzee bijdrage aan de Balans van de

\section{Leefomgeving}




\section{NatuurBalans Noordzee}

\section{Voorbeeld uitwerking van een Noordzee bijdrage aan de Balans van de Leefomgeving}

Auteur(s): $\quad$ J.E. Tamis, R.H. Jongbloed, A. Asjes, P. de Vries, G.J. Piet

Dit onderzoek is uitgevoerd door Wageningen Marine Research in opdracht van PBL op verzoek van en gefinancierd door het Ministerie van Landbouw, Natuur en Voedselkwaliteit, in het kader van Beleidsondersteunend onderzoekthema 'Additionele kennisbasismiddelen 2018' (projectnummer KB-33-001-028)

Wageningen Marine Research

IJmuiden, april 2019 
Keywords: Balans voor de leefomgeving, Kaderrichtlijn Marien

Opdrachtgever: Planbureau voor de Leefomgeving

T.a.v.: dr. P. Vugteveen

Bezuidenhoutseweg 30

2594 AV Den Haag

Op verzoek van het Ministerie van Landbouw, Natuur en Voedselkwaliteit

KB-33-001-028

Dit rapport is gratis te downloaden van https://doi.org/10.18174/474503

Wageningen Marine Research verstrekt geen gedrukte exemplaren van rapporten.

Wageningen Marine Research is ISO 9001:2015 gecertificeerd.

(C) 2018 Wageningen Marine Research

Wageningen Marine Research, instituut binnen de rechtspersoon Stichting

Wageningen Research, hierbij

vertegenwoordigt door Dr. M.C.Th.

Scholten, Algemeen directeur

KvK nr. 09098104,

WMR BTW nr. NL 8113.83.696.B16.

Code BIC/SWIFT address: RABONL2U

IBAN code: NL 73 RABO 0373599285
Wageningen Marine Research aanvaardt geen aansprakelijkheid voor gevolgschade, noch voor schade welke voortvloeit uit toepassingen van de resultaten van werkzaamheden of andere gegevens verkregen van Wageningen Marine Research opdrachtgever vrijwaart Wageningen Marine Research van aanspraken van derden in verband met deze toepassing.

Alle rechten voorbehouden. Niets uit deze uitgave mag weergegeven en/of gepubliceerd worden, gefotokopieerd of op enige andere manier gebruikt worden zonder schriftelijke toestemming van de uitgever of auteur. 


\section{Inhoud}

Samenvatting

Inleiding

1.1 Achtergrond $\quad 8$

1.2 Kennisvraag $\quad 9$

$\begin{array}{llr}1.3 & \text { Leeswijzer } & 9\end{array}$

$2 \quad$ Aanpak voor de beoordeling huidige toestand $\quad 10$

$\begin{array}{ll}2.1 & \text { Inleiding } \\ 2.2 & 10\end{array}$

$\begin{array}{ll}2.2 & \text { Indicatoren } \\ 2.3 & 10\end{array}$

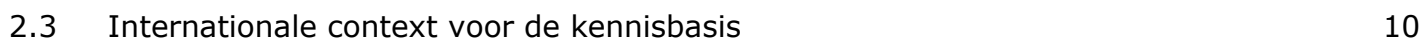

2.4 DPSIR 11

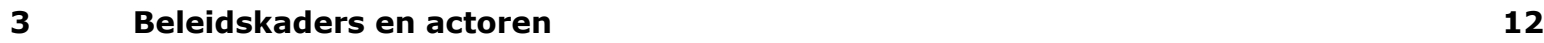

3.1 Begrenzing beleidskaders 12

$\begin{array}{lll}3.2 & \text { Kaderrichtlijn Mariene Strategie (KRM) } & 14\end{array}$

$\begin{array}{ll}3.3 & \text { Kaderrichtlijn Water (KRW) } \\ 3.47\end{array}$

$\begin{array}{lll}3.4 & \text { Vogel- en Habitatrichtlijn (VHR) } & 18\end{array}$

$\begin{array}{lll}3.5 & \text { Gemeenschappelijk visserijbeleid (GVB) } & 21\end{array}$

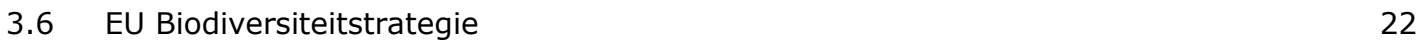

$\begin{array}{lll}3.7 & \text { (Inter)nationale actoren } & 23\end{array}$

$\begin{array}{lll}3.8 & \text { Beleidskaders voor de NatuurBalans Noordzee } & 24\end{array}$

$4 \quad$ Beschrijving toestand van de Noordzee $\quad 25$

$\begin{array}{lll}4.1 & \text { Inleiding } & 25\end{array}$

4.2 Natuur: Structuur en functioneren $\quad 26$

4.2.1 Zeezoogdieren $\quad 26$

4.2.2 Zeevogels

$\begin{array}{lll}4.2 .3 & \text { Vissen } & 37\end{array}$

$\begin{array}{lll}4.2 .4 & \text { Zeebodem } & 42\end{array}$

4.2.5 Waterkolom $\quad 46$

$\begin{array}{lll}4.3 & \text { Menselijke activiteiten en hun drukfactoren } & 50\end{array}$

$\begin{array}{lll}\text { 4.3.1 Niet-inheemse soorten } & 50\end{array}$

4.3.2 Visserij: vangst en bijvangst $\quad 53$

$\begin{array}{lll}4.3 .3 & \text { Eutrofiëring } & 58\end{array}$

4.3.4 Verstoring en verlies zeebodem $\quad 63$

$\begin{array}{lll}\text { 4.3.5 Hydrografische eigenschappen } & 68\end{array}$

$\begin{array}{lll}4.3 .6 & \text { Vervuilende stoffen } & 70\end{array}$

$\begin{array}{lll}4.3 .7 & \text { Zwerfvuil } & 74\end{array}$

$\begin{array}{lll}\text { 4.3.8 Onderwatergeluid } & 78\end{array}$

$\begin{array}{lll}4.4 & \text { Ecosysteemdiensten } & 82\end{array}$

$\begin{array}{llr}5 & \text { Integrale beoordeling } & 84\end{array}$

$\begin{array}{llc}5.1 & \text { Introductie } & 84\end{array}$

$\begin{array}{llr}5.2 & \text { Evaluatie per KRM Descriptor } & 88\end{array}$

$\begin{array}{lll}5.3 & \text { Relevantie voor beheer } & 96\end{array}$

$\begin{array}{lll}\text { 5.3.1 Risico versus status } & 96\end{array}$

$\begin{array}{ll}\text { 5.3.2 Belangrijkste drukfactoren en activiteiten } & 98\end{array}$ 
$\begin{array}{llr}6.1 & \text { Beoordeling KRM } & 100\end{array}$

6.2 Programma van Maatregelen $\quad 101$

6.3 Kennisvragen 102

$\begin{array}{ll}6.4 & \text { Beleidsdoelen voor de leefomgeving } \\ \end{array}$

$\begin{array}{llr}7 & \text { Discussie en aanbevelingen } & 108\end{array}$

$\begin{array}{llr}7.1 & \text { Toestandsbeschrijving } & 108\end{array}$

$\begin{array}{llr}7.2 & \text { Evaluatie beleid } & 108\end{array}$

$\begin{array}{llr}7.3 & \text { Evaluatie van maatregelen } & 109\end{array}$

$8 \quad$ Kwaliteitsborging $r 110$

$\begin{array}{lr}\text { Literatuur } & 111\end{array}$

$\begin{array}{lr}\text { Verantwoording } & 115\end{array}$

$\begin{array}{llr}\text { Bijlage } 1 & \text { Relatie CLO indicatoren en KRM } & 116\end{array}$

$\begin{array}{llr}\text { Bijlage } 2 & \text { Relevantie AQUACROSS voor Nederlandse Noordzee } & 118\end{array}$

$\begin{array}{llr}\text { Bijlage } 3 \quad \text { KRM indicatoren: initiële opzet } & 121\end{array}$

$\begin{array}{llr}\text { Bijlage } 4 & \text { KRM indicatoren: geactualiseerd } & 123\end{array}$

$\begin{array}{llr}\text { Bijlage } 5 & \text { KRM indicatoren: parameters en drempelwaarden } & 124\end{array}$

$\begin{array}{llr}\text { Bijlage } 6 & \text { Habitatrichtlijnsoorten } & 128\end{array}$

$\begin{array}{llr}\text { Bijlage } 7 & \text { OSPAR biodiversity indicators } & 130\end{array}$

$\begin{array}{llr}\text { Bijlage } 8 & \text { Bow tie analyses } & 131\end{array}$ 


\section{Samenvatting}

Dit is een voorbeeld uitwerking van de toestand van de natuur in de Noordzee in relatie tot de verschillende beleidsdoelstellingen als mogelijke bijdrage aan de Balans van de Leefomgeving. De Balans van de Leefomgeving is een tweejaarlijkse publicatie van het Planbureau voor de Leefomgeving $(\mathrm{PBL})$ waarin het rijksbeleid voor milieu, natuur en ruimte wordt geëvalueerd. De Balans van de Leefomgeving geeft een onderbouwd inzicht in de huidige kwaliteit van de fysieke leefomgeving en in hoeverre de gestelde beleidsdoelen worden gehaald, inclusief mogelijke verklaringen. Tot nog toe was de Noordzee geen onderdeel van de Balans van de Leefomgeving maar dit gaat mogelijk in de toekomst veranderen.

Deze verkennende NatuurBalans Noordzee is bedoeld om hier invulling aan te geven, waarbij de beschikbare informatie voor een toestandbeoordeling van de natuur in de Noordzee gepresenteerd wordt en gerelateerd aan de meest relevante specifiek mariene beleidskaders zoals met name de Kaderrichtlijn Marien (KRM). Maar ook gerelateerd aan verschillende vormen van menselijk gebruik van de zee (visserij en aansluitend op de verdere ontwikkeling van een Blauwe Economie) en aan beleidsdoelen die voortkomen uit de balans voor de leefomgeving of aansluiten bij biodiversiteit en ecosysteemdiensten (bijvoorbeeld de Biodiversiteitstrategie 2020 relevant voor LNV). In de Balans van de Leefomgeving is het gebruikelijk om de toestand van de natuur te beschrijven aan de hand van de indicatoren uit het Compendium voor de Leefomgeving (CLO). In voorliggende rapportage is vaak afgeweken van die CLO indicatoren omdat voor de meest relevante mariene beleidskaders (met name $\mathrm{KRM}$ ) reeds indicatoren bestaan die in een internationale context afgestemd zijn en dus ook het meest beleidsrelevant zijn.

De opzet van deze NatuurBalans Noordzee is gebaseerd op de zogenoemde DPSIR-cyclus, waarbij een activiteit (driver), middels een drukfactor (pressure), de toestand (status) beïnvloedt en een verandering veroorzaakt (impact) welke middels een of meerdere maatregelen (respons) kan worden voorkomen of tenietgedaan waarmee de cyclus weer rond is. De DPSIR-cyclus is leidend in het marien ecosysteem-gericht beheer en de elementen zijn dan ook terug te vinden in de verschillende beleidskaders. De milieutoestand volgens de KRM is gebaseerd op elf descriptoren (D1-D11) waarvan vier de toestand van het mariene ecosysteem beschrijven: D1 Biodiversiteit, D3 Commerciële visbestanden, D4 Voedselweb en D6 Integriteit van de zeebodem. De overige betreffen verstoringen ('drukfactoren') van het mariene ecosysteem als gevolg van menselijke activiteiten. Er zijn voor iedere descriptor meerdere criteria vastgesteld om te beoordelen of de beleidsdoelstelling, een goede milieutoestand (GMT), is bereikt. Voor ieder criterium kunnen één of meerdere indicatoren gebruikt worden om dit te beoordelen. Verschillende descriptoren komen terug in de overige beleidskaders zoals bijvoorbeeld voor de voornaamste natuur-gerelateerde doelstellingen van het Gemeenschappelijk Visserij Beleid (KRM D3) of die van de Vogel \& Habitat Richtlijn (KRM D1). De verschillende descriptoren en elementen van de DPSIR-cyclus waarop dit rapport gebaseerd is staan geordend in de onderstaande figuur. 


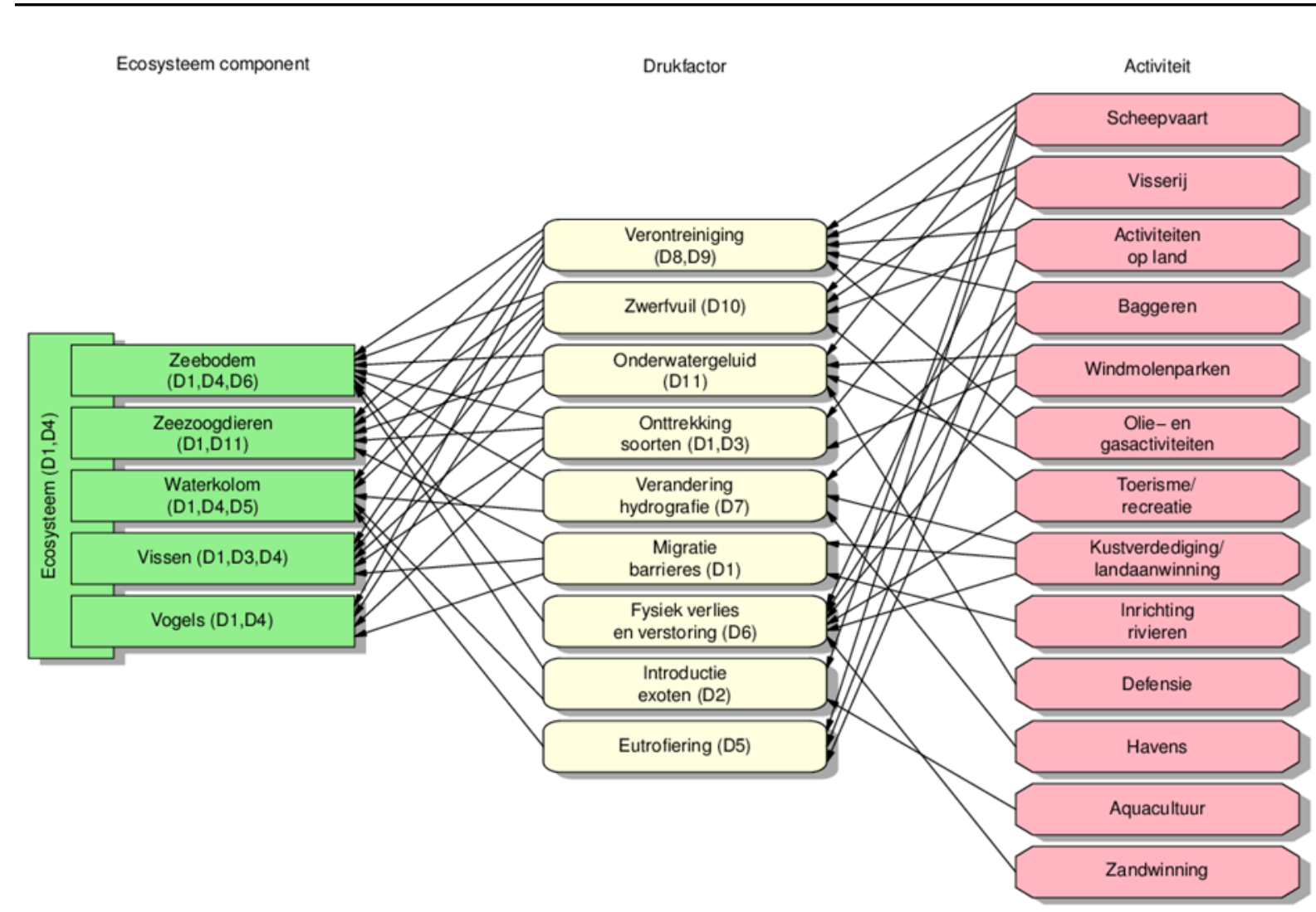

Voor de ecosysteemcomponenten (soorten en habitats) en drukfactoren gerelateerd aan de gestelde beleidsdoelen is de beschikbare informatie beschreven en vervolgens verwerkt tot een integrale beoordeling. Hierbij is gekozen voor verschillende perspectieven:

(1) Gericht op wat beschouwd wordt als het meest relevante beleidskader, de KRM, waarvoor per descriptor en criteria wordt aangegeven in hoeverre GMT behaald is. Die laat zien dat voor 22 criteria de GMT is gehaald en voor 14 criteria (nog) niet is gehaald. Voor 16 criteria is het nog onbekend is, bijvoorbeeld vanwege het gebrek aan een beoordelingsmethodiek en/of grenswaarden. Momenteel is slechts voor 2 descriptoren (D9: vervuilende stoffen in vis en D7: hydrografische eigenschappen) de GMT gehaald.

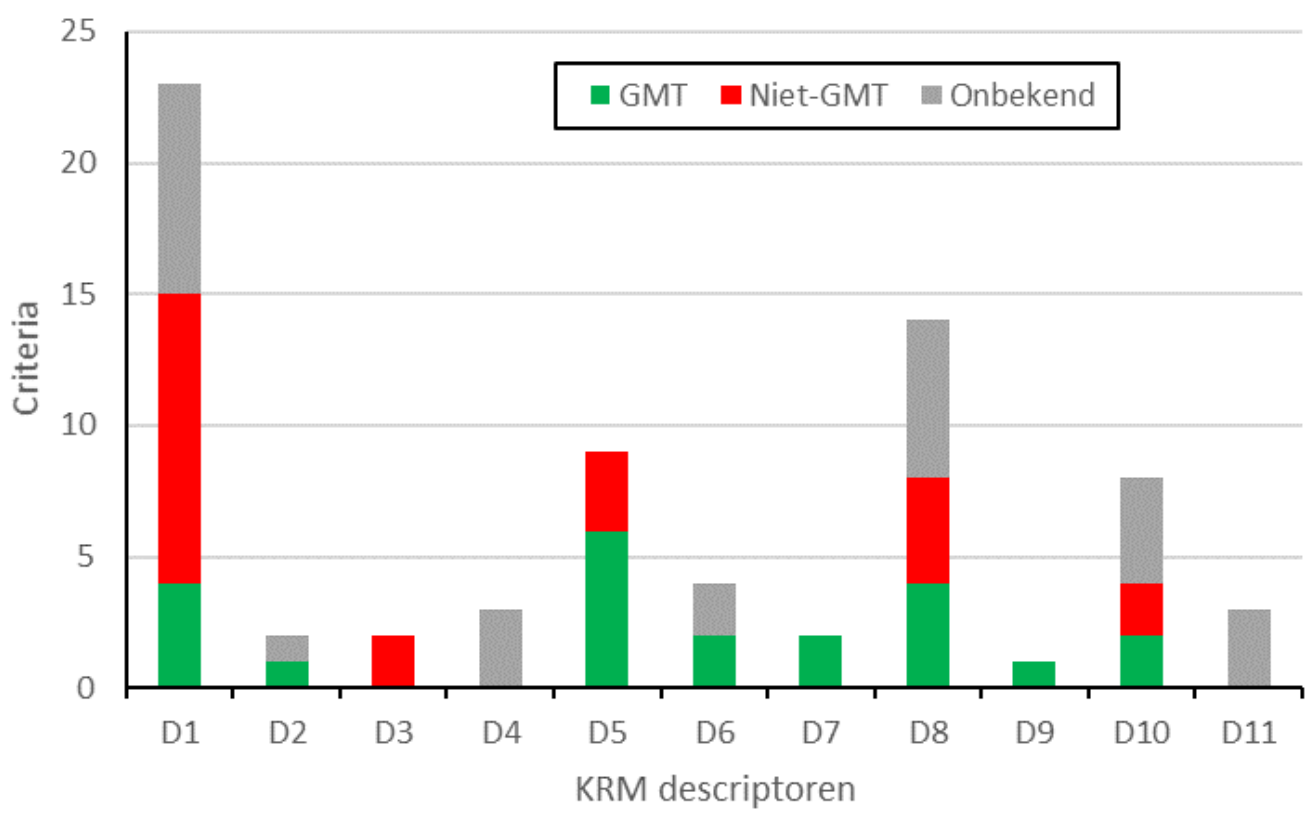

(2) Gericht op de relevantie voor beheer waarbij de toestandbeoordeling per ecosysteemcomponent (status) en drukfactor is gecombineerd met een risicobeoordeling (risico) op grond van een cumulatieve effecten analyse (CEA). Dit onderscheidt drie klassen voor wat betreft de prioriteit voor beheer: 
- Hoge prioriteit (Status slecht \& Risico hoog). Vereist maximale inzet van maatregelen en nader onderzoek naar risico's en oorzaken van de slechte status. Visserij, zwerfvuil en vervuilende stoffen zijn de drukfactoren met het hoogste risico op het Noordzee ecosysteem en waarvoor de GMT niet bereikt is. Tezamen met deze drukfactoren geldt dat de cumulatieve effecten van alle menselijke activiteiten tezamen een hoog risico met zich meebrengen en ertoe geleid hebben dat de ecosysteem componenten nog geen GMT bereikt hebben.

- Gemiddelde prioriteit (Status goed \& Risico hoog of Status slecht \& Risico laag). Vereist een focus op monitoring, 'hand aan de kraan-principe' en onderzoek naar risico's, met eventuele herstelmaatregelen. Dit geldt voor bijvoorbeeld onderwatergeluid en de zeezoogdieren. De kans bestaat namelijk dat de toestand van de zeezoogdieren (en andere ecosysteem componenten) verder onder druk komt te staan als gevolg van de energietransitie op zee. Daarom is er een kennisopgave met betrekking tot cumulatie specifiek voor wind op zee.

- $\quad$ Lage prioriteit (Status goed \& Risico laag). Vereist geen directe actie, monitoring voldoet. Het bestaand beleid voldoet om de GMT van de drukfactoren eutrofiëring en niet-inheemse soorten te bereiken. Wel is er een kennisopgave met betrekking tot de toename van hard substraat (exoten) en de verhouding fosfaat-stikstof (eutrofiëring).

Een evaluatie van het huidige beleid laat zien dat dit niet lijkt te voldoen voor het behalen van in ieder geval de beleidsdoelen met betrekking tot biodiversiteit van zeebodem, vis en zeevogels alsook zwerfvuil. Verwacht mag worden dat dit ook geldt voor het functioneren van de voedselwebben wanneer dit aspect verder ontwikkeld wordt. 


\section{Inleiding}

\subsection{Achtergrond}

Wageningen Marine Research (WMR) is gevraagd in deze rapportage een voorbeeld uit te werken over de toestand van de natuur in de Noordzee als mogelijke bijdrage aan de Balans van de Leefomgeving (en tussen-balans). De Balans van de Leefomgeving is een tweejaarlijkse publicatie van het Planbureau voor de Leefomgeving (PBL) waarin het rijksbeleid voor milieu, natuur en ruimte wordt geëvalueerd. De Balans geeft een onderbouwd inzicht in de huidige kwaliteit van de fysieke leefomgeving en in hoeverre de gestelde beleidsdoelen worden gehaald, inclusief mogelijke verklaringen.

Hiertoe worden een aantal indicatoren uit het Compendium voor de Leefomgeving (CLO) verwerkt tot een stoplichttabel (symbolen in groen, oranje en rood om aan te geven in hoeverre beleidsdoelen worden gehaald). Alhoewel er verschillende indicatoren voor de Noordzee beschikbaar zijn, is de Balans van de Leefomgeving voornamelijk gericht op de land- en zoetwaternatuur en is een evaluatie van de Noordzee momenteel niet beschikbaar. Deze rapportage is bedoeld om hier invulling aan te geven, met indicatoren en stoplichten specifiek gericht op de Noordzee. Als focus voor relevante beleidskaders is gekozen voor de Kaderrichtlijn Marien (KRM), met doelen die aansluiten bij biodiversiteit en ecosysteemdiensten (bv de Biodiversiteitstrategie 2020 relevant voor LNV), milieucondities (relevant voor I\&W) en gerelateerd aan verschillende vormen van menselijk gebruik (visserij en aansluitend op de verdere ontwikkeling van een Blauwe Economie). Dit wordt dan de basis voor een concept CLO-factsheets/natuurbalans-achtergronddocument wat dan weer de basis wordt voor een aanzet tot een eerste NatuurBalans Noordzee. Tenslotte wordt een doorkijk geboden naar de mogelijkheden voor eventuele toekomstige rapportages NatuurBalans Noordzee.

Naast deze invulling voor mogelijke bijdrage aan de (tussen) Balans voor de Leefomgeving is ook gevraagd om een bijdrage te leveren aan de Natuurverkenning, wat afzonderlijk wordt gerapporteerd (Jongbloed et al., in prep.). Deze beide producten zijn vervolgens de basis voor een modellenvisie (Piet et al., in prep.) die er specifiek op gericht is de benodigde kennis te borgen voor de continuering en verdere ontwikkeling van die producten. Alhoewel deze drie producten afzonderlijk worden gerapporteerd zijn ze wel aan elkaar gerelateerd, zoals schematisch is weergegeven in Figuur 1.

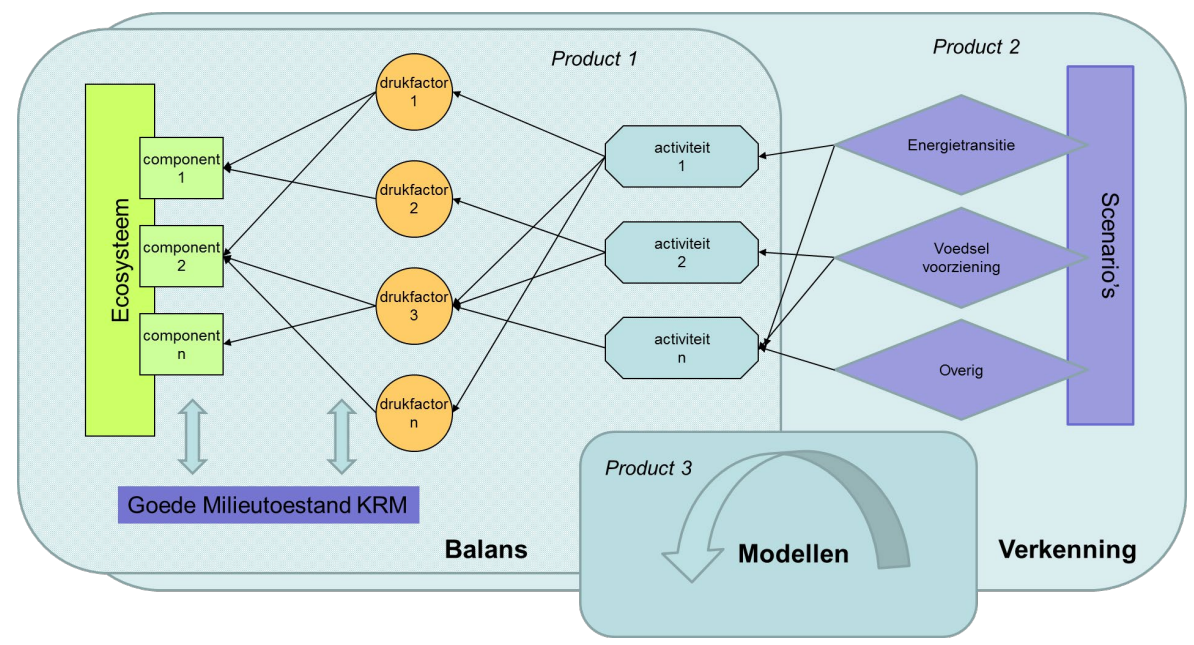

Figuur 1 Schematische weergave van de (mogelijke) relaties tussen de drie afzonderlijke producten (balans; verkenning; modellenvisie) voor het PBL. 


\subsection{Kennisvraag}

Twee vragen staan centraal voor deze rapportage voor de NatuurBalans Noordzee (tweejaarlijks product):

- Hoe staat het ervoor met natuur in de Noordzee?

- Hoe is dit gerelateerd aan het huidige natuurbeleid voor de Noordzee? Dit gaat zowel om de actuele ontwikkelingen, de effectiviteit als ook de mogelijke uitkomst van ingezet beleid.

\subsection{Leeswijzer}

In hoofdstuk 2 wordt beschreven op welke wijze invulling is gegeven om voor de Noordzee een bijdrage te leveren aan de Balans van de Leefomgeving. Een belangrijk onderdeel daarbij zijn de verschillende beleidskaders en actoren die voor de Noordzee relevant zijn, welke in hoofdstuk 3 worden beschreven.

Hoofdstuk 4 geeft een overzicht van de beschikbare informatie en beschrijft de toestand voor ieder van de ecosysteemcomponenten (soorten en habitats, paragraaf 4.2) en drukfactoren (paragraaf 4.3) gerelateerd aan de gestelde doelen. Ook wordt hier een eerste doorkijk gegeven naar de ecosysteemdiensten die (mogelijk) door de Noordzee geleverd kunnen worden (paragraaf 4.4). Die informatie wordt vervolgens in Hoofdstuk 5 geaggregeerd tot een integrale beoordeling. Hierbij is gekozen voor verschillende perspectieven:

- Gericht op wat beschouwd wordt als het meest relevante beleidskader, de Kaderrichtlijn Marien (KRM), en beschrijft de toestand op basis van de elf descriptoren van de KRM (zie paragraaf 3.2). Dit is dus direct beleidsrelevant maar toegespitst op een specifiek beleidskader.

- Gericht op de relevantie voor beheer met een beoordeling per ecosysteemcomponent en drukfactor.

In Hoofdstuk 6 wordt dit afgerond met een evaluatie van huidig beleid en beheer waarbij de Noordzee informatie specifiek gerelateerd wordt aan de beleidsdoelen voor de leefomgeving. Discussie en aanbevelingen staan tenslotte beschreven in hoofdstuk 7. 


\section{Aanpak voor de beoordeling huidige toestand}

\subsection{Inleiding}

Voor de beoordeling van de huidige toestand van de natuur in de Balans van de Leefomgeving gebruikt het PBL indicatoren (zie paragraaf 2.22). Voor deze eerste beschrijving van de huidige toestand van de mariene natuur hebben we ons laten leiden door verschillende beleidsdoelen die voor de Noordzee gesteld zijn in de verschillende beleidskaders: Kaderrichtlijn Marien (KRM); Kaderrichtlijn Water (KRW), Vogel- en Habitatrichtlijn (VHR); Gemeenschappelijk Visserijbeleid (GVB); en EU Biodiversiteitsstrategie. Hierbij is de KRM, die specifiek gericht is op het mariene milieu, centraal gesteld. De verschillende beleidskaders en actoren worden in hoofdstuk 3 nader besproken.

\subsection{Indicatoren}

Het PBL beschrijft de toestand van de natuur aan de hand van indicatoren. Deze indicatoren worden op het Compendium voor de Leefomgeving (CLO, https://www.clo.nl/) gepresenteerd, samen met indicatoren van het Centraal Bureau voor de Statistiek (CBS), het Rijksinstituut voor Volksgezondheid en Milieu (RIVM) en Wageningen UR. Gezamenlijk geven deze indicatoren de stand van milieu, natuur en ruimte in Nederland weer in feiten en cijfers. Deze indicatoren noemen wij hier 'CLO indicatoren'.

Voor de beoordeling van de toestand van het mariene milieu bestaan reeds veel indicatoren die uit verplichtingen te rapporteren voor diverse (internationale) beleidskaders. Veel daarvan zijn ontwikkeld en/of in gebruik genomen nadat de CLO indicatoren gekozen waren. Bijvoorbeeld voor de Kaderrichtlijn Marien (KRM, zie Hoofdstuk 3) wordt inmiddels een uitgebreide set indicatoren gehanteerd (hier genoemd 'KRM indicatoren'). De KRM indicatoren hebben als voordeel dat ze: direct beleidsrelevant zijn; de volledige milieutoestand van de Noordzee omvatten; veelal regionaal (met andere Noordzeelanden, meestal door OSPAR) zijn afgestemd; in monitoringprogramma's zijn of worden opgenomen. We hebben in dit rapport daarom de KRM indicatoren als uitgangspunt gekozen om gebruikt te worden in de Balans van de Leefomgeving. Waar relevant zullen deze aangevuld worden met de huidige CLO indicatoren. De relatie tussen de twee sets van indicatoren staat weergegeven in Bijlage 1.

\subsection{Internationale context voor de kennisbasis}

Voor de beoordeling van de toestand van de Noordzee is de internationale context van belang. OSPAR is het platform dat de afstemming tussen de Noordzee lidstaten coördineert. Andere relevante organisaties zijn ICES en de European Environment Agency (EEA). Een belangrijk deel van de kennisbasis voor afzonderlijke onderdelen (specifieke sectoren of ecosysteem componenten) is voor specifieke beleidsvragen ontwikkeld (vaak in internationaal kader). Tenslotte zijn er recent enkele internationale projecten geweest om die kennisbasis verder te vergroten zodat ook een meer integraal perspectief ontwikkeld kan worden. Binnen het Europese KP7 project ODEMM is de basis gelegd voor een cumulatieve effecten analyse (CEA) waarbij het risico op impact door activiteiten op onderdelen van het marine ecosysteem wordt ingeschat (Knights et al., 2015). Deze CEA methodiek is binnen het Europese $\mathrm{H} 2020$ project AQUACROSS verder ontwikkeld en toegepast voor o.a. de (internationale) Noordzee (Piet et al., 2018; Borgwardt et al., 2019). Deze CEA methodiek is gebruikt om invulling te geven aan toestandsbeoordelingen en beleidsevaluaties voor het PBL. In de beschrijving van de huidige toestand van de Noordzee (hoofdstuk 4) zijn enkele resultaten gebaseerd op de CEA 
methodiek meegenomen. De relevantie van een CEA voor de Nederlandse Noordzee is beknopt weergegeven in Bijlage 2. In een eerder stadium is door Piet et al. (2014) de CEA methodiek toegepast voor een evaluatie van het Nederlandse KRM Programma van Maatregelen. De resultaten van deze studie zijn in hoofdstuk 6.1.2 meegenomen.

\subsection{DPSIR}

De opzet van deze verkennende NatuurBalans Noordzee is gebaseerd op de zogenoemde DPSIR-cyclus van activiteiten (driver), die middels een drukfactor (pressure), de toestand (status) beïnvloed en een verandering veroorzaakt (impact) welke middels een of meerdere maatregelen (respons) kan worden voorkomen of tenietgedaan waarmee de cyclus weer rond is (Figuur 2 en Tabel 1). De DPSIR cyclus is leidend in het marien ecosysteem-gericht beheer en de elementen zijn dan ook terug te vinden in de verschillende beleidskaders. Dit geldt met name voor de KRM (zie Tabel 1 en Hoofdstuk 3).

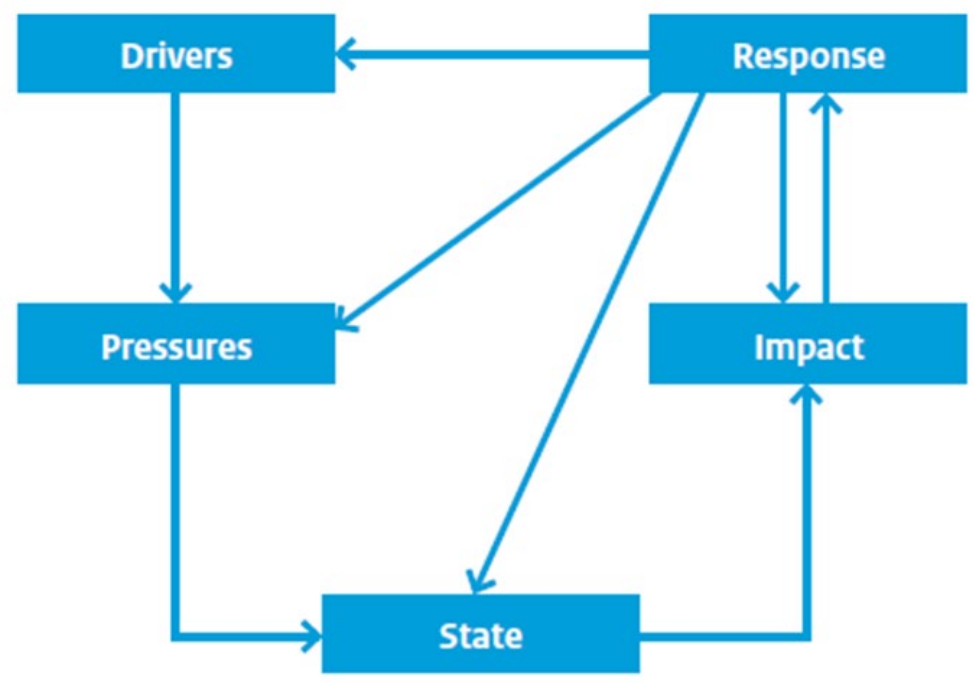

Figuur 2 Drivers, Pressure, State, Impact en Respons-model (Ministerie van IenW \& LNV, 2018).

Tabel 1 Toelichting DPSIR-cyclus en relatie met de KRM (Ministerie van IenW \& LNV, 2018)

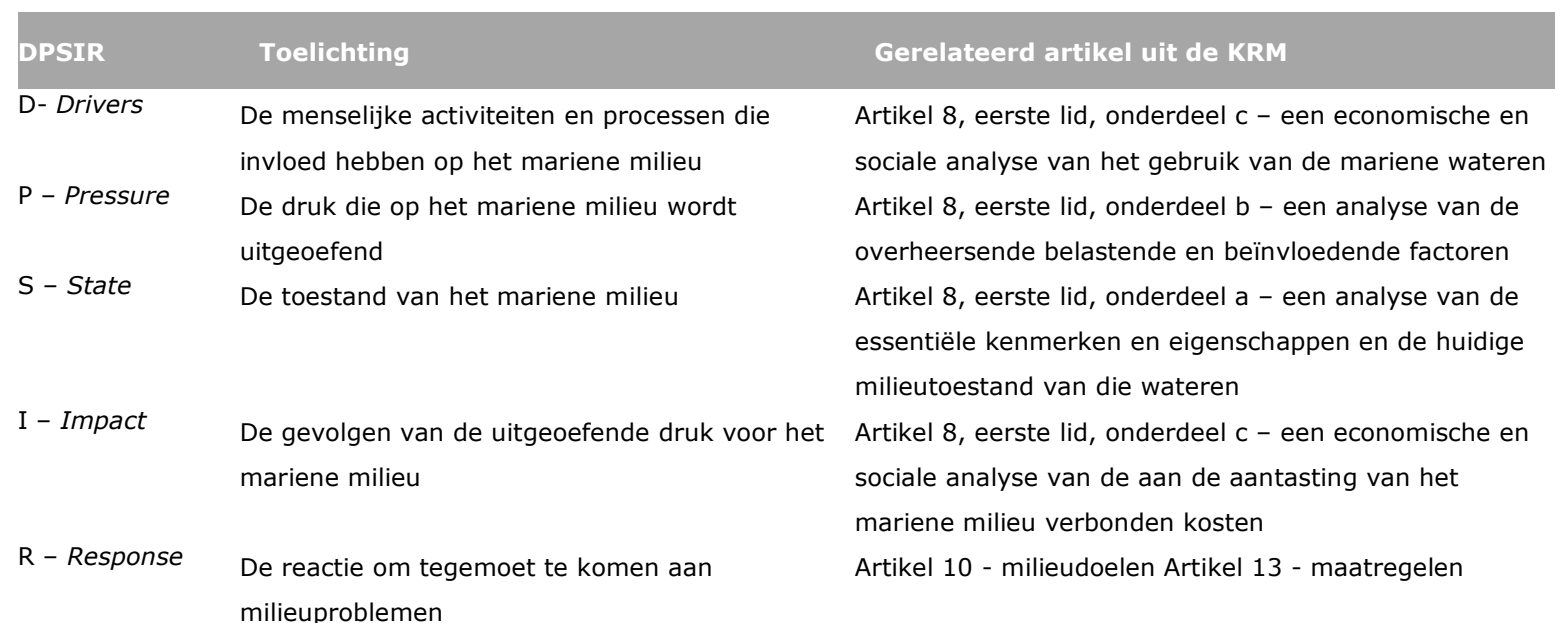




\section{Beleidskaders en actoren}

\subsection{Begrenzing beleidskaders}

Diverse beleidskaders zijn voor de Noordzee relevant: de Kaderrichtlijn Marien (KRM), de Kaderrichtlijn Water (KRW), de Vogel- en Habitatrichtlijn (VHR), het gemeenschappelijk Visserijbeleid (GVB) en de EU-Biodiversiteit Strategie.

De Noordzee kent per beleidskader specifieke begrenzingen. De Noordzee is vanaf circa één kilometer uit de kust niet gemeentelijk of provinciaal ingedeeld. Daar is alleen het rijk verantwoordelijk. De territoriale zee, die zich uitstrekt tot 12 zeemijl gemeten vanaf de laaglaagwaterlijn, is het gebied waar de Nederlandse wetgeving geldt. De minister van IenW is coördinerend bewindspersoon voor het integrale Noordzeebeleid en -beheer. De minister van IenW deelt deze verantwoordelijkheid met de minister van LNV, vanwege diens verantwoordelijkheid voor de beleidsterreinen biodiversiteit, natuur en visserij (Ministerie van IenW \& LNV, 2018).

De KRM heeft betrekking op het Nederlandse deel van de Noordzee (Figuur 3). Dit toepassingsgebied betreft het water, de zeebodem en de ondergrond zeewaarts van de basiskustlijn vanwaar de breedte van de territoriale zee wordt gemeten (artikel 3 van de KRM). De internationale grenzen van het Nederlandse Continentaal Plat (NCP) vormen de buitengrens van het toepassingsgebied. Dit is tevens de grens van de Exclusieve Economische Zone, de EEZ (Ministerie van IenW \& LNV, 2018). Het Nederlandse deel van de Noordzee maakt onderdeel uit van OSPAR regio II (the Greater North Sea), zie de inzet in Figuur 3. Bij de internationale/regionale afstemming van het beleid van de Noordzee speelt OSPAR een belangrijke rol.

De KRW geldt niet in de gehele Noordzee maar alleen in de 'kustwateren' ofwel de territoriale zee. Dit is de zone tot 12 zeemijl vanaf de basiskustlijn (de zogenoemde). In dit gebied geldt in de zone tot 1 zeemijl de Ecologische Toestand en tot 12 zeemijl de Chemische Toestand van de KRW. Het toepassingsgebied van de KRW overlapt dus gedeeltelijk met dat van de KRM. De KRM is hier alleen van toepassing op elementen die van belang zijn voor de bescherming van het mariene milieu en die niet vallen onder de KRW (Ministerie van IenW \& LNV, 2018).

De VHR is in Nederland geïmplementeerd in de Wet natuurbescherming die van kracht is binnen de EEZ. De VHR vereist dat lidstaten speciale beschermingszones aanwijzen ten behoeve van het Europese Natura 2000-netwerk. Op de Noordzee zijn 6 Natura2000-gebieden aangewezen: de Voordelta en de Noordzeekustzone (VHR-gebieden), de Vlakte van de Raan, de Doggersbank en de Klaverbank (HR-gebieden), en het Friese Front (VR-gebied), zie paragraaf 3.4.

Het GVB en de EU Biodiversiteit Strategie is Europees beleid en omvat daarmee de vier Europese zeeën: de Middellandse Zee, Zwarte Zee, Oostzee en Noord-Atlantische Oceaan, waartoe ook de Noordzee behoort. Voor Nederland gelden hierbij verder geen specifieke begrenzingen. 


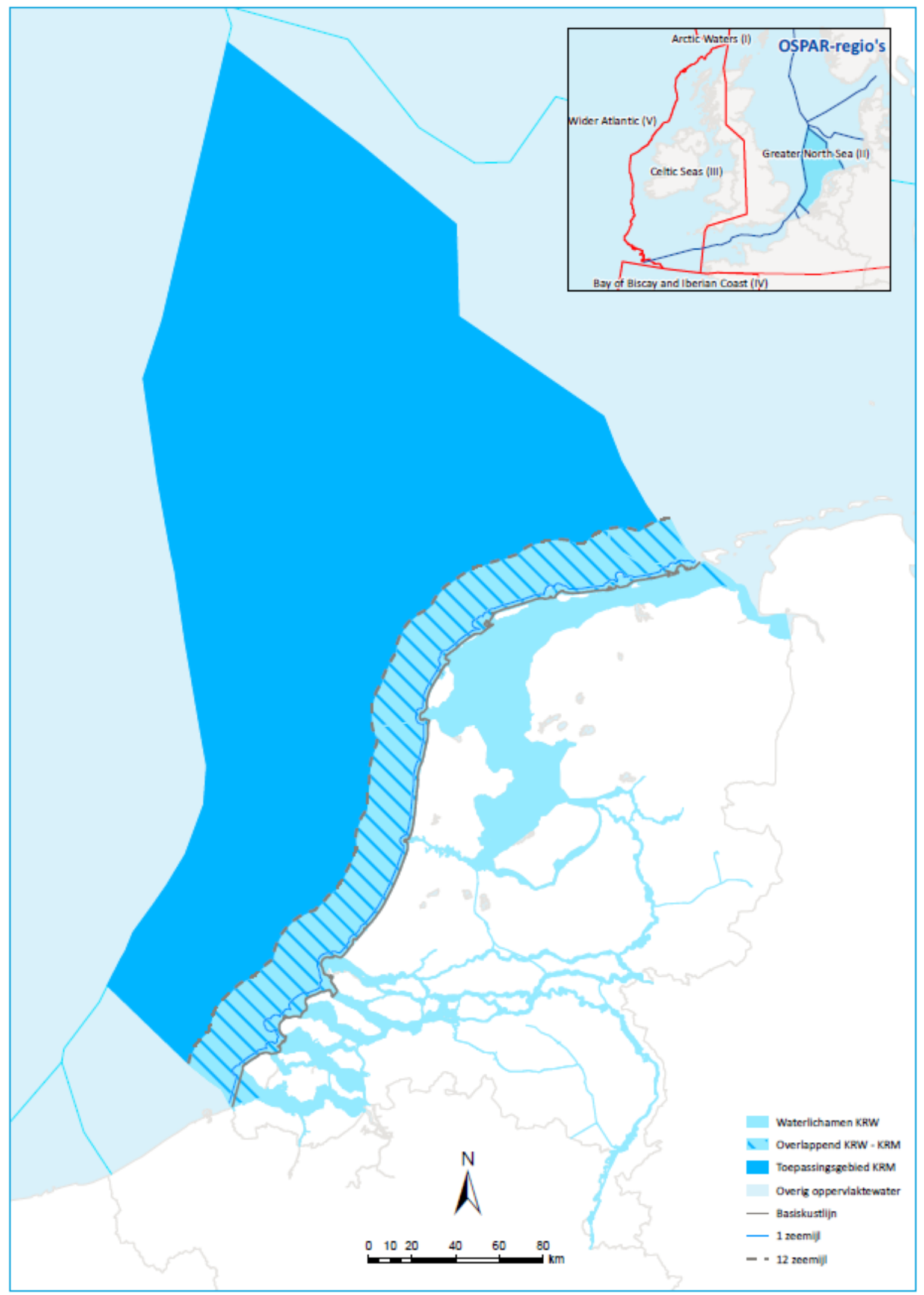

Figuur 3 Toepassingsgebied KRM, KRW-waterlichamen en OSPAR-gebieden (Ministerie van IenW \& $L N V, 2018)$. 


\subsection{Kaderrichtlijn Mariene Strategie (KRM)}

De Europese Kaderrichtlijn Mariene Strategie (KRM), die in 2008 van kracht is geworden, stelt een kader vast waarbinnen de lidstaten de nodige maatregelen nemen om uiterlijk in 2020 een goede milieutoestand (GMT, in het Engels GES: Good Environmental Status) van het mariene milieu te bereiken of te behouden. Daartoe worden zogenaamde mariene strategieën ontwikkeld en uitgevoerd om:

- $\quad$ het mariene milieu te beschermen en in stand te houden, de verslechtering ervan te voorkomen of, waar uitvoerbaar, mariene ecosystemen in de gebieden waar deze schade hebben geleden te herstellen;

- $\quad$ inbreng in het mariene milieu te voorkomen en te verminderen, teneinde geleidelijk aan de verontreiniging zoals gedefinieerd in artikel 3, lid 8, weg te nemen zodat zij geen gevolgen van betekenis heeft of een significant risico vormt voor de mariene biodiversiteit, de mariene ecosystemen, de volksgezondheid of het rechtmatig gebruik van de zee.

Nederland moet rapporteren voor de mariene subregio: "Noordzee in ruime zin, met inbegrip van het Kattegat en het Kanaal" als onderdeel van de regio "Noordoostelijk deel van de Atlantische Oceaan". De KRM is in 2010 opgenomen in het Waterbesluit onder de Waterwet.

Een mariene strategie bestaat uit:

1) Een initiële beoordeling van de huidige milieutoestand van de betrokken wateren en de milieueffecten van menselijke activiteiten (Artikel 8); een omschrijving van de goede milieutoestand van de betrokken wateren (Artikel 9) aan de hand van een reeks milieudoelen en daarmee samenhangende indicatoren (Artikel 10)

2) Een monitoringprogramma voor de voortgaande beoordeling en periodieke actualisering van de doelen (Artikel 11)

3) Een programma van maatregelen dat gericht is op het bereiken of behouden van een goede milieutoestand (Artikel 13).

De milieutoestand is gebaseerd op elf descriptoren (Figuur 4), waarvan vier de toestand van het mariene ecosysteem beschrijven: biodiversiteit, commerciële visbestanden, voedselweb en integriteit van de zeebodem. Deze zijn, gezien vanuit de ecosysteembenadering, cruciaal voor de milieutoestand. De andere descriptoren betreffen verstoringen ('drukfactoren') van het mariene ecosysteem als gevolg van menselijke activiteiten (EC, 2011). De elf descriptoren (met daarbij aangegeven of het een weergave van status en/of drukfactor is) zijn:

- D1 Biodiversiteit (status ecosysteem);

- D2 Niet-inheemse soorten (drukfactor);

- $\quad$ D3 Commerciële visbestanden (status ecosysteem en drukfactor);

- D4 Voedselweb (status ecosysteem);

- $\quad$ D5 Eutrofiering (status ecosysteem en drukfactor);

- D6 Integriteit van de zeebodem (status ecosysteem en drukfactor);

- $\quad$ D7 Hydrografische eigenschappen (drukfactor);

- $\quad$ D8 Vervuilende stoffen (drukfactor);

- $\quad$ D9 Vervuilende stoffen in vis (drukfactor);

- D10 Zwerfvuil (drukfactor);

- D11 Energietoevoer, o.m. onderwatergeluid (drukfactor). 


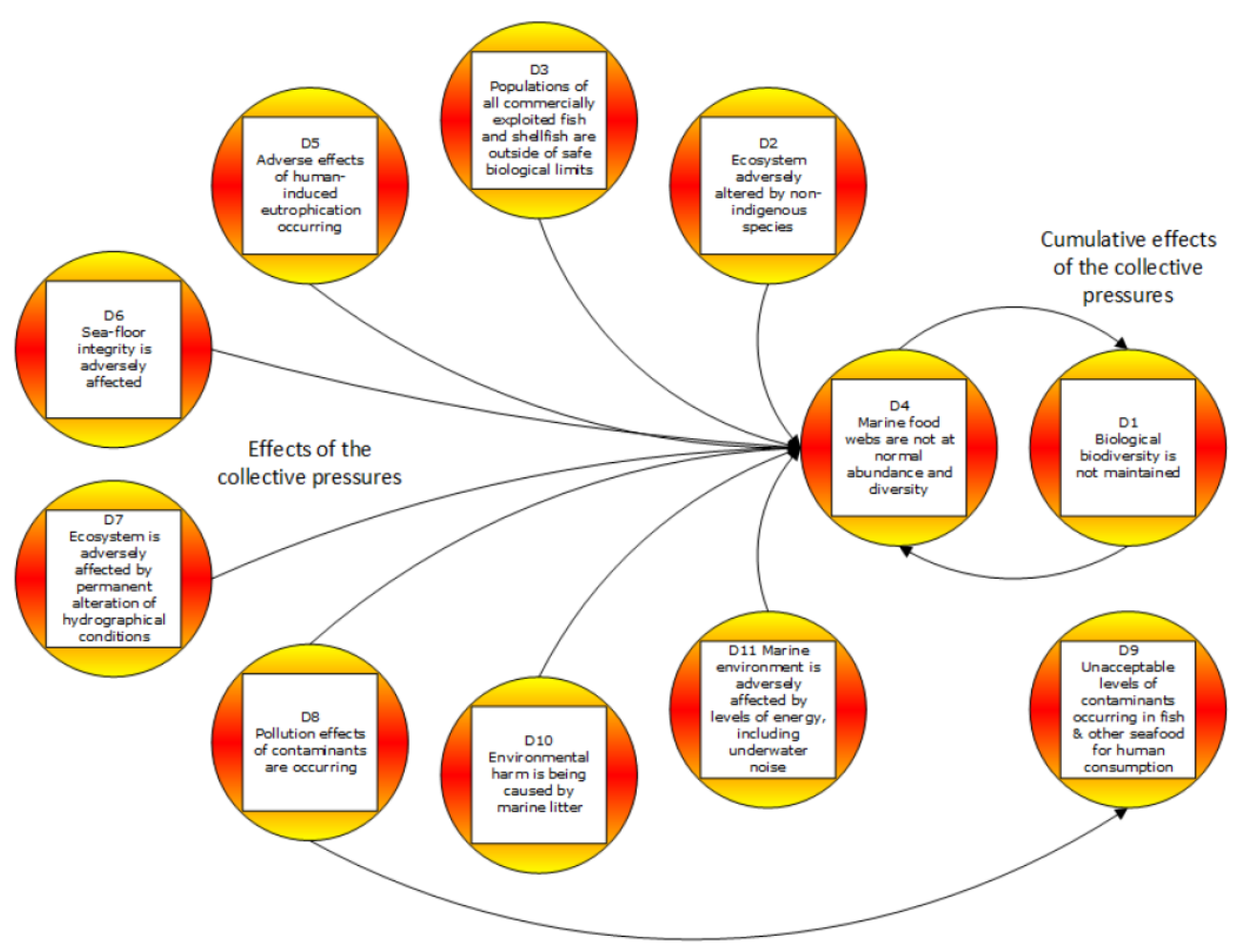

Figuur 4 Gevolgen van het niet halen van de goede milieutoestand (GMT) van de descriptoren (Cormier et al., 2018). Bij elke Descriptor (D) staat wanneer GMT niet bereikt wordt en is aangegeven welke andere Descriptoren wordt beïnvloed. D1 (biodiversiteit) en D4 (voedselweb) ondervinden gevolgen van elkaar en van alle andere descriptoren die (deels) gerelateerd zijn aan een specifieke drukfactor (D2: niet-inheemse soorten; D3: visserij; D5: eutrofiëring; D6: fysiek verlies en verstoring van de zeebodem; D7: aantasting van hydrografische condities; D8: vervuilende stoffen (welke ook direct invloed heeft op D9: vervuilende stoffen in vis(producten)); D10: zwerfvuil; D11: energie, inclusief onderwatergeluid).

Mariene Strategie Deel 1: Huidige milieutoestand, goede milieutoestand, milieudoelen en indicatoren In 2012 is de Mariene Strategie voor het Nederlandse deel van de Noordzee 2012-2020, Deel 1 vastgesteld en aan de Europese Commissie gerapporteerd (Ministerie van IenM \& ELenI, 2012). Hierin zijn de initiële beoordeling van het mariene milieu voor 2012, de goede milieutoestand voor 2020 en daarbij behorende milieudoelen en indicatoren (32 in totaal, zie Bijlage 3) voor het Nederlandse deel van de Noordzee omschreven en gerangschikt naar de elf milieudescriptoren van de richtlijn. Er zijn voor iedere descriptor meerdere criteria vastgesteld om te beoordelen of de beleidsdoelstelling, een goede milieutoestand (GMT), is bereikt. Voor ieder criterium kunnen daarvoor een of meerdere indicatoren gebruikt worden. De milieudoelen dienen de voortgang tot GMT te begeleiden en met behulp van de indicatoren is af te meten in welke mate de actuele toestand van de goede toestand verschilt (zie Figuur 5). 
Descriptoren D1 t/m D11

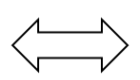

GMT Criteria D1C1 t/m D11C2

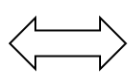

Milieudoelen D1CT1 t/m D11T3

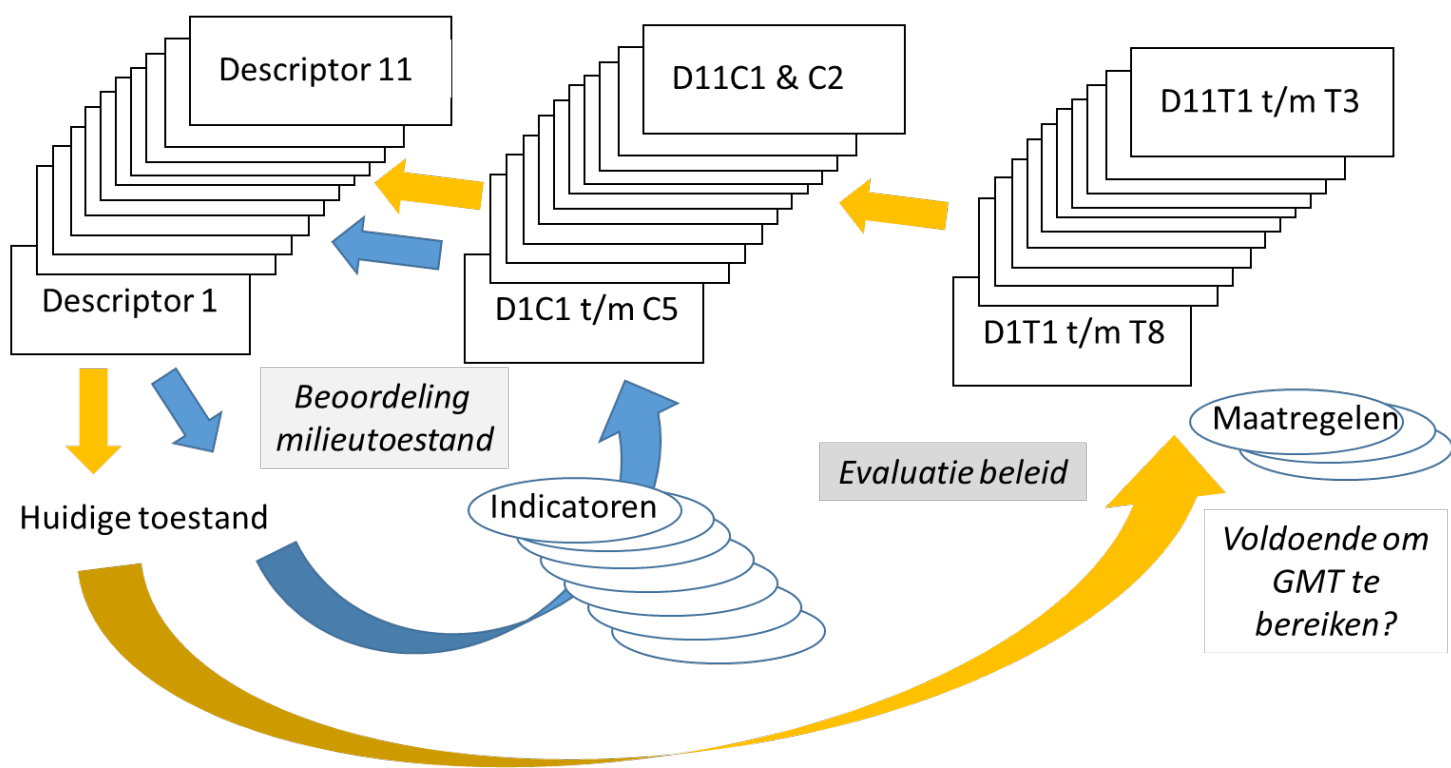

Figuur 5 Schematische weergave van de kaderrichtlijn mariene strategie (KRM), waarbij de goede milieutoestand (GMT) is vastgesteld in criteria per descriptor. Met behulp van de indicatoren is af te meten of aan de GMT wordt voldaan (beoordeling milieutoestand: blauwe pijlen). De milieudoelen dienen de voortgang tot GMT te begeleiden en maken onderdeel uit van de beleidsevaluatie (gele pijlen).

In 2018 is de Mariene Strategie Deel 1 herzien voor de periode 2018-2024 (Ministerie van IenW \& LNV, 2018). Dit betreft een actualisatie van de huidige milieutoestand, goede milieutoestand, milieudoelen en indicatoren. De geactualiseerde lijst van indicatoren is opgenomen in Bijlage 4 en Bijlage 5 (inclusief eventuele parameters en drempelwaarden). In de actualisatie van deel 1 is de beoordeling van de huidige milieutoestand gebaseerd op de voorgeschreven criteria en uitgevoerd met de informatie uit het KRM-monitoringprogramma. Daarbij is, omwille van een internationaal consistente aanpak, zoveel mogelijk aangesloten bij de in OSPAR-kader ontwikkelde beoordelingsmethoden en is niet langer vastgehouden aan de 32 indicatoren zoals opgesteld in 2012. De KRM verplicht de EU-lidstaten tot een regionale aanpak met nadrukkelijk een coördinerende rol voor de bestaande regionale zeeconventies. Voor de Noordzee is dat OSPAR (zie 'Internationale verdragen'). OSPAR heeft als regionaal platform een belangrijke rol gehad bij de internationale samenwerking met betrekking tot de actualisatie van de Mariene Strategie deel 1 (Ministerie van IenW \& LNV, 2018), onder andere door het ontwikkelen van gemeenschappelijke indicatoren en het uitvoeren van de Intermediate Assessment (OSPAR, 2017).

Daarnaast is bij het actualiseren van de Mariene Strategie deel 1 rekening gehouden met beleid, randvoorwaarden en ambities vanuit verschillende beleidsvelden die relevant zijn voor de goede milieutoestand, met name het Gemeenschappelijk Visserijbeleid (GVB), de Kaderrichtlijn Water (KRW), de Vogelrichtlijn (VR), Habitatrichtlijn (HR), en het Biodiversiteitsverdrag (CBD) (Ministerie van IenW \& LNV, 2018). Deze beleidskaders worden verderop in dit hoofdstuk kort toegelicht.

Mariene Strategie Deel 2: Monitoringprogramma

In Deel 2 van de Mariene Strategie voor het Nederlandse deel van de Noordzee 2012-2020 (Ministerie van IenM \& EZ, 2014) wordt het monitoringprogramma beschreven. Het KRM-monitoringprogramma is opgesteld conform artikel 11 van de richtlijn en werkt de concrete monitoring van de 32 indicatoren 
uit de Mariene Strategie Deel 1 in detail uit. Het monitoringprogramma geeft op basis van meetgegevens inzicht in (Ministerie van IenM \& EZ, 2014):

1. de status van de indicatoren en daarmee in de mate waarin een milieudoel wordt bereikt (KRM, art. 10). Dit ten behoeve van voortgaande beoordeling en periodieke actualisering van de milieudoelen (KRM, art. 5)

2. de effectiviteit van het onder de KRM uit te voeren programma van maatregelen.

Mariene Strategie Deel 3: Programma van maatregelen

Eind 2015 is het eerste programma van maatregelen vastgesteld (Ministerie van IenM \& EZ, 2015). Voor een deel van de maatregelen is het nog te vroeg om te kunnen bepalen of ze het gewenste effect hebben. Wanneer uit de huidige toestand blijkt dat er nieuwe of grotere opgaven zijn, overweegt het kabinet aanvullend beleid. Dat gebeurt in 2021 bij de actualisatie van Mariene Strategie deel 3 (het programma van maatregelen).

\section{Beleidsnota Noordzee 2016-2021}

Het nationale beleidsmatige kader voor de Mariene Strategie, inclusief deel 3 het programma van maatregelen (Ministerie van IenM \& EZ, 2015) is vastgelegd in de Beleidsnota Noordzee 2016-2021. (Ministerie van IenM, 2015a). De Beleidsnota Noordzee 2016-2021 is onderdeel van het Nationaal Waterplan 2016-2021 (Ministerie van I\&M, 2015b) en wordt vanaf 2016 uitgevoerd. Het Nederlands Noordzeebeleid is integraal. Het omvat alle doelen en ambities voor het Nederlandse deel van de Noordzee. De ecosysteembenadering en het voorzorgbeginsel zijn belangrijke uitgangspunten van het integrale beleid.

\section{Strategische Agenda Noordzee 2030}

Het kabinet is gestart met het ontwikkelen van een Strategische Agenda Noordzee 2030 voor de periode na 2020. De beleidsmatige aangrijpingspunten hiervoor zijn ontleend aan de lange termijn scenario's van het Planbureau voor de Leefomgeving (PBL) (Matthijsen et al., 2018). De Strategische Agenda Noordzee 2030 is een bouwsteen voor de Nationale Omgevingsvisie die in 2019 wordt vastgesteld. De Mariene Strategie stelt hierbij de kaders voor een gezonde zee met een duurzaam gebruik (Ministerie van I\&W en Ministerie van LNV, 2018). De strategische opgaven zijn:

- Bereiken van een gezonde zee met een duurzaam en verantwoord gebruik;

- In balans realiseren van de energietransitie, natuurherstel en voedselvoorziening, in samenhang met de ontwikkeling van andere sectoren en kustregio's;

- Bevorderen van een innovatieve en concurrerende Blauwe Economie.

\subsection{Kaderrichtlijn Water (KRW)}

Sinds 22 december 2000 is in de hele EU de Europese Kaderrichtlijn Water (KRW) van kracht. Doel van de richtlijn is om binnen vijftien jaar (dus in 2015) alle oppervlaktewateren en grondwatersystemen in 'een goede ecologische en chemische toestand' te brengen en zo 'natte' natuur te beschermen en te verbeteren. Naast het zoete water geldt dit ook voor het zoute water in kust- en overgangsgebieden.

De KRW gaat uit van een stroomgebiedbenadering. Alle vier de Nederlandse stroomgebieden (Rijn, Maas, Eems en Schelde) omvatten een stukje Noordzee (Figuur 6); zo omvat het Rijnstroomgebied de Noord-Hollandse kust en het westelijke deel van de Wadden. Voor ecologische doelstellingen kijkt men tot $1 \mathrm{mijl}$ uit de kust, voor chemische doelstellingen tot $12 \mathrm{mijl}$.

In Nederland vertaalt de rijksoverheid de KRW in landelijke beleidsuitgangspunten, kaders en instrumenten. De minister van Infrastructuur en Milieu is eindverantwoordelijk voor de implementatie van de KRW. Zij overlegt met andere ministeries en de (koepelorganisaties van) provincies, waterschappen en gemeenten. Ook zullen de waterkwaliteitsbeheerders van de Noordzee ervoor moeten zorgen dat het bestaande milieubeleid voor de Noordzee uit het OSPAR-verdrag op de KRW aansluit. 
Het KRW beoordelingssysteem om de ontwikkeling van de kwaliteit in kaart te brengen is onder andere gebaseerd op kwaliteitselementen zoals fytoplankton, bodemdieren en hydromorfologie.

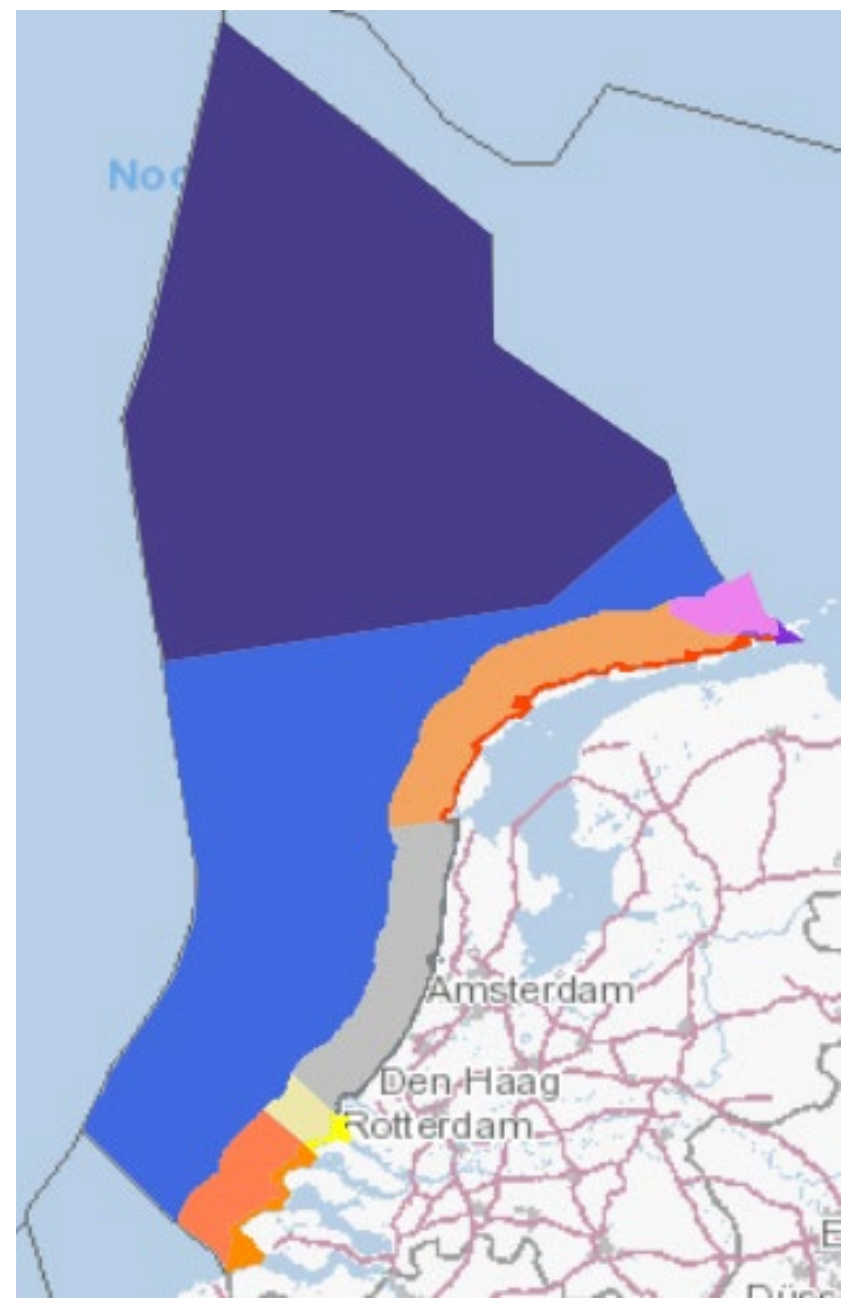

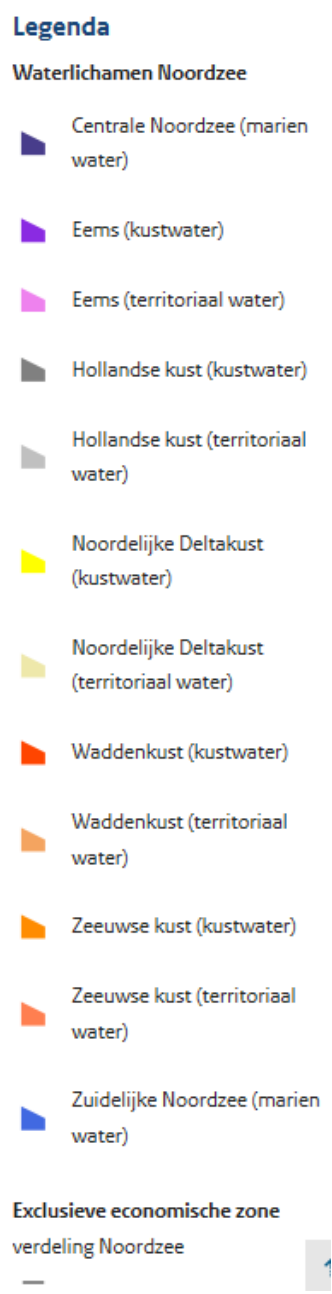

-

Figuur 6 Waterlichamen Noordzee (https://www.noordzeeloket.nl/beheer/noordzeeatlas/deel-iiibeleid-0/kaderrichtlijn-water/).

\subsection{Vogel- en Habitatrichtlijn (VHR)}

De Vogel- en Habitatrichtlijn is specifiek voor respectievelijk het behoud van de vogelstand en instandhouding van de natuurlijke habitats. Natura 2000 is het Europese netwerk van beschermde natuurgebieden onder de Habitatrichtlijn (1992) en de Vogelrichtlijn (1979). Doel is het beschermen en behouden van Europa's meest waardevolle en bedreigde dier- en plantensoorten en leefgebieden. De Europese Commissie raadt aan tenminste 20 tot 60 procent van de oppervlaktes van de kwalificerende habitattypen te beschermen. De soorten die door de Habitatrichtlijn beschermd worden (Bijlage 6) zijn in bijlagen van de richtlijn genoemd:

- Bijlage II: Voor soorten van Bijlage II die geregeld in ons land voorkomen, moet Nederland beschermde gebieden aanwijzen;

- Bijlage IV: Nederland moet voor soorten en hun voortplantings- of rustplaatsen van bijlage IV, waarvoor ons land tot het natuurlijke verspreidingsgebied behoort, beschermingsmaatregelen nemen. Alle soorten die na 1900 in het wild in Nederland zijn waargenomen en in bijlage IV zijn opgenomen, vallen onder deze bescherming;

- Bijlage V: Voor soorten van Bijlage V kunnen de lidstaten, indien nodig, maatregelen treffen om te zorgen dat het aan de natuur onttrekken en de exploitatie van deze soorten niet ten koste gaat van hun behoud. 
De bescherming van soorten door de Habitatrichtlijn is verwerkt in de Wet natuurbescherming en is voor soorten in bijlage II alleen van kracht in de aangewezen beschermde gebieden. De bescherming van soorten in bijlage IV zijn strikt beschermd (artikel 3.5) en de soorten in bijlage $V$ zijn beschermd tegen onttrekking en exploitatie (artikel 3.7).

De Vogelrichtlijn kent verschillende categorieën van soorten:

- Geregeld voorkomende trekvogel (artikel 4.2 Vogelrichtlijn)

- Bijlage I: bedreigde soorten en trekvogels (artikel 4.1 Vogelrichtlijn;)

- Bijlage II: jacht toegestaan, onder bepaalde condities (artikel 7 Vogelrichtlijn)

- Bijlage III: handel toegestaan, onder bepaalde condities (artikel 6 Vogelrichtlijn)

Alle vogels die van nature in het wild in Nederland voorkomen zijn beschermd op grond van de Europese Vogelrichtlijn.

In de Vogel- en Habitatrichtlijn (Natura 2000), in de KRM en in het OSPAR-verdrag is bepaald dat gebieden met bijzondere ecologische waarden op zee moeten worden beschermd. De Nederlandse overheid heeft onder andere besloten om bepaalde vormen van gebruik uit bepaalde gebieden te weren. Een aantal al bestaande (Natura 2000) gebieden valt hieronder, maar er is ook een voorstel gedaan voor aanvullende gebieden. Uiteindelijk heeft de overheid zichzelf als doel gesteld om in 2020 10 tot 15 procent van de Nederlandse Noordzeebodem te beschermen tegen 'noemenswaardige' beroering. Een beschermd gebied sluit niet per se uit dat er menselijke activiteiten plaats kunnen vinden; dat hangt af van het type gebied, het type gebruik en de verstoringsgevoeligheid. Wat onder een 'beschermd gebied' wordt verstaan kan dus variëren, afhankelijk van het doel van de implementatie en de te beschermen natuurwaarden.

Op termijn moet bescherming van de individuele gebieden ertoe leiden dat er een samenhangend netwerk van beschermde gebieden op zee ontstaat (Ministerie van Infrastructuur en Milieu en Ministerie van Economische Zaken, 2014). In Tabel 2 en Figuur 7 wordt een overzicht gegeven van gebieden op de Noordzee die (mogelijk) beschermd worden. Voor aangewezen gebieden moeten binnen drie jaar na aanwijzing de beheerplannen zijn afgerond met hierin de instandhoudingsdoelstellingen, de uitwerking daarvan in omvang ruimte en tijd, hoe deze doelen behaald zullen worden en wat dit betekent voor bestaande en nieuwe activiteiten (Ministerie van Infrastructuur en Milieu en Ministerie van Economische Zaken, 2014). De beschermde natuurwaarden (soorten en habitats) van de aangewezen gebieden staan weergegeven in Tabel 3.

Tabel 2 Overzicht (mogelijk) beschermde gebieden op de Noordzee

\begin{tabular}{|c|c|c|}
\hline Gebieden & Toelichting & Status \\
\hline Voordelta & Vogel- en Habitatrichtlijngebied & Aangewezen (24/03/2000). \\
\hline Vlakte van de Raan & Habitatrichtlijngebied & Aangewezen (14/03/2011). \\
\hline Noordzeekustzone & Vogel- en Habitatrichtlijngebied & $\begin{array}{l}\text { Aangewezen }(26 / 02 / 2009) \text {. Wijzigingsbesluiten }(27 / 12 / 2010 ; \\
04 / 10 / 2012 ; 18 / 10 / 2012)\end{array}$ \\
\hline Doggersbank & Habitatrichtlijngebied & Aangewezen (ontwerpbesluit 12/09/2014) \\
\hline Klaverbank & Habitatrichtlijngebied & Aangewezen (ontwerpbesluit 12/09/2014) \\
\hline \multirow[t]{2}{*}{ Friese Front } & Vogelrichtlijngebied & Aangewezen (ontwerpbesluit 12/09/2014) \\
\hline & Bodembescherming KRM* & Voorgesteld (Schultz van Haegen-Maas Geesteranus, 2016) \\
\hline Gasfonteinen & Habitatrichtlijngebied & Afgewezen \\
\hline Zeeuwse banken & Habitatrichtlijngebied & Afgewezen \\
\hline Borkumse Stenen & Habitatrichtlijngebied & Lopend onderzoek \\
\hline Bruine Bank & Vogelrichtlijngebied & Lopend onderzoek \\
\hline Centrale Oestergronden & Bodembescherming KRM* & Voorgesteld (Schultz van Haegen-Maas Geesteranus, 2016) \\
\hline
\end{tabular}




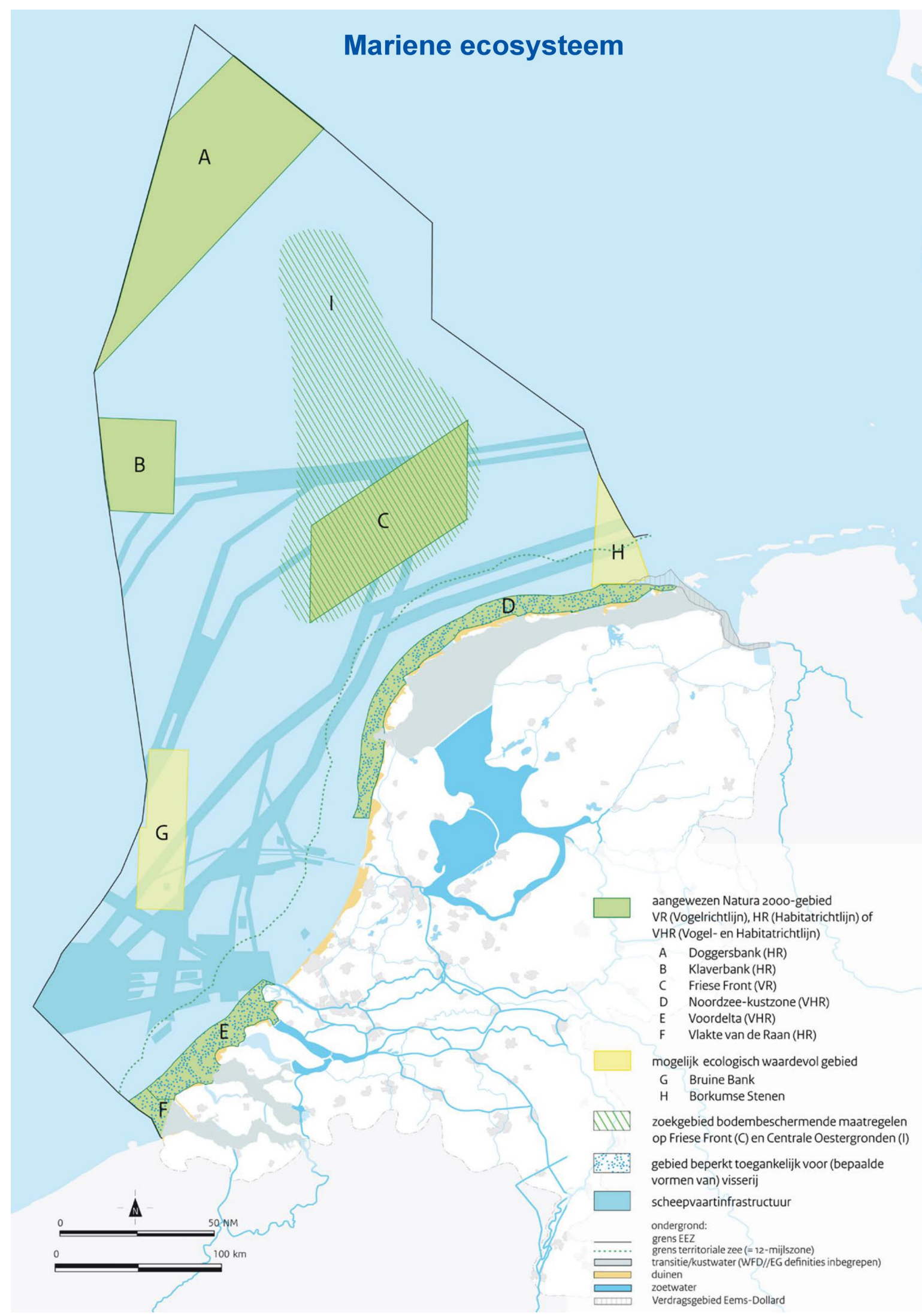

Figuur 7 Beschermde gebieden binnen de EEZ (https://www.noordzeeloket.nl/functiesgebruik/natuur/). 
Tabel 3 Overzicht van de doelen van de Natura 2000-gebieden in de territoriale zee en de Exclusieve Economische Zone (EEZ). Per gebied is aangegeven welke doelen (habitats en soorten) zijn aangemeld, volgens het aanwijzingsbesluit van het betreffende gebied en de website

http://www.noordzeenatura2000.nl/

\begin{tabular}{|c|c|c|c|c|c|c|c|}
\hline \multicolumn{3}{|c|}{ Doelen voor habitattypen en soorten } & \multicolumn{5}{|c|}{ Gebiedsdoelen } \\
\hline & Code & Omschrijving & 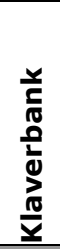 & 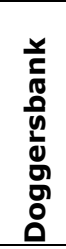 & 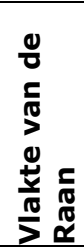 & 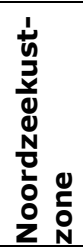 & 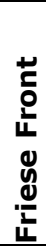 \\
\hline \multirow[t]{8}{*}{ Habitattype } & $\mathrm{H} 1170$ & Riffen & & & & & \\
\hline & H1110_B & $\begin{array}{l}\text { Permanent overstroomde zandbanken } \\
\text { (Noordzeekustzone) }\end{array}$ & & & & & \\
\hline & H1110_C & Permanent overstroomde zandbanken (Doggersbank) & & & & & \\
\hline & H1140_B & Slik- en zandplaten (Noordzeekustzone) & & & & & \\
\hline & $\mathrm{H} 1310$ & Zilte pionierbegroeiingen & & & & & \\
\hline & $\mathrm{H} 1330$ & Schorren en zilte graslanden & & & & & \\
\hline & $\mathrm{H} 2110$ & Embryonale duinen & & & & & \\
\hline & $\mathrm{H} 2190$ & Vochtige duinvalleien & & & & & \\
\hline \multirow[t]{3}{*}{ Vissen } & $\mathrm{H} 1095$ & Zeeprik & & & & & \\
\hline & H1099 & Rivierprik & & & & & \\
\hline & $\mathrm{H} 1103$ & Fint & & & & & \\
\hline \multirow[t]{3}{*}{ Zoogdieren } & $\mathrm{H} 1351$ & Bruinvis & & & & & \\
\hline & $\mathrm{H} 1364$ & Grijze zeehond & & & & & \\
\hline & H1365 & Gewone zeehond & & & & & \\
\hline \multirow[t]{21}{*}{ Vogels } & $\mathrm{A} 001$ & Roodkeelduiker & & & & & \\
\hline & $\mathrm{A} 002$ & Parelduiker & & & & & \\
\hline & $\mathrm{A} 017$ & Aalscholver & & & & & \\
\hline & $\mathrm{A} 048$ & Bergeend & & & & & \\
\hline & A062 & Topper & & & & & \\
\hline & $\mathrm{A} 063$ & Eider & & & & & \\
\hline & A065 & Zwarte zee-eend & & & & & \\
\hline & $\mathrm{A} 130$ & Scholekster & & & & & \\
\hline & $\mathrm{A} 132$ & Kluut & & & & & \\
\hline & A137 & Bontbekplevier & & & & & \\
\hline & A138 & Strandplevier & & & & & \\
\hline & $\mathrm{A} 141$ & Zilverplevier & & & & & \\
\hline & A143 & Kanoet & & & & & \\
\hline & $\mathrm{A} 144$ & Drieteenstrandloper & & & & & \\
\hline & A149 & Bonte strandloper & & & & & \\
\hline & A157 & Rosse grutto & & & & & \\
\hline & $\mathrm{A} 160$ & Wulp & & & & & \\
\hline & A169 & Steenloper & & & & & \\
\hline & A177 & Dwergmeeuw & & & & & \\
\hline & A195 & Dwergstern & & & & & \\
\hline & A199 & Zeekoet & & & & & \\
\hline
\end{tabular}

\subsection{Gemeenschappelijk visserijbeleid (GVB)}

Het Gemeenschappelijk visserijbeleid (GVB) is een regeling voor het beheer van de Europese vissersvloten en voor het behoud van de visbestanden. Het GVB zet in op een ecologisch, economisch en maatschappelijk duurzame visserij. Voornaamste ijkpunten voor het beheer van de bestanden zijn "maximale duurzame opbrengst" (Maximum Sustainable Yield, MSY) en wetenschappelijk advies (EU, 2016). Maatregelen met betrekking tot de visserij buiten de territoriale zee (tot 12 zeemijl gemeten 
vanaf de laaglaagwaterlijn, het gebied waar de Nederlandse wetgeving geldt, zie ook paragraaf 3.5) vallen onder de exclusieve competentie van de Europese Commissie in het kader van GVB. In 2013 is het Gemeenschappelijke Visserijbeleid hervormd en is besloten om een aanlandplicht in te stellen. Daarvoor moesten de vissers vis waarvoor ze geen quotum (meer) hadden of ondermaatse vis juist terugzetten in zee (discarden). De Europese aanlandplicht betekent dat vissers alle commerciële soorten (vissoorten die onder een vangstquotum vallen of waarvoor een minimummaat geldt) aan land moeten brengen (https://ec.europa.eu/fisheries/cfp/fishing_rules/discards_en). De aanlandplicht wordt stapsgewijs tussen 2015 en 2019 ingevoerd voor verschillende soorten en visserijen (Steins et al., 2018).

\subsection{EU Biodiversiteitstrategie}

In mei 2011 heeft de Europese Commissie een nieuwe strategie voor de biodiversiteit aangenomen om het hoofdstreefdoel voor de biodiversiteit te halen. De strategie geeft het kader voor de maatregelen die de EU de volgende tien jaar zal nemen dat. Hoofdstreefdoel voor de EU voor 2020 is: Het biodiversiteitsverlies en de aantasting van ecosysteemdiensten in de EU uiterlijk tegen 2020 stoppen en, voor zover dit haalbaar is, ongedaan maken, en tevens de bijdrage van de EU tot het ombuigen van wereldwijd biodiversiteitsverlies opvoeren.

De strategie is opgebouwd rond zes elkaar ondersteunende streefdoelen die gericht zijn op de voornaamste oorzaken van het biodiversiteitsverlies en tot doel hebben de invloed van de belangrijkste factoren die de natuur en de ecosystemen in de EU onder druk zetten, te reduceren. Elk streefdoel wordt opgesplitst in een aantal termijn gebonden acties en andere begeleidende maatregelen. De voor de Noordzee relevante streefdoelen staan hieronder vermeld.

\section{STREEFDOEL 1: DE HABITAT- EN DE VOGELRICHTLIJN VOLLEDIG UITVOEREN}

De achteruitgang in de staat van alle onder de natuurwetgeving van de EU vallende soorten en habitats stoppen en een aanzienlijke en meetbare verbetering van hun staat realiseren zodat tegen 2020, vergeleken met huidige beoordelingen: (i) $100 \%$ meer habitatbeoordelingen en $50 \%$ meer soortbeoordelingen in het kader van de habitatrichtlijn een gunstige of verbeterde staat van instandhouding laten zien en (ii) uit 50 \% meer soortenbeoordelingen in het kader van de vogelrichtlijn een veilige of verbeterde staat van instandhouding blijkt.

\section{STREEFDOEL 2: ECOSYSTEMEN EN ECOSYSTEEMDIENSTEN HANDHAVEN EN HERSTELLEN}

Tegen 2020 zullen ecosystemen en ecosysteemdiensten worden gehandhaafd en verbeterd door groene infrastructuur op te zetten en ten minste $15 \%$ van de aangetaste ecosystemen te herstellen.

\section{STREEFDOEL 4: DUURZAAM GEBRUIK VAN VISBESTANDEN VERZEKEREN}

Tegen 2015 maximale duurzame opbrengsten (MDO's) realiseren. Ervoor zorgen dat de populaties een leeftijdsopbouw en grootteverdeling bereiken die duiden op een gezond bestand, door een visserijbeheer te voeren dat geen significante nadelige effecten op andere bestanden, soorten en ecosystemen heeft, met als doel tegen 2020 een goede milieutoestand te bereiken, zoals de kaderrichtlijn mariene strategie voorschrijft.

\section{STREEFDOEL 5: INVASIEVE UITHEEMSE SOORTEN BESTRIJDEN}

Tegen 2020 zullen invasieve uitheemse soorten en hun introductieroutes in kaart worden gebracht en geprioriteerd, zullen prioritaire soorten in de hand worden gehouden of worden uitgeroeid en zullen hun routes worden beheerd om de introductie en vestiging van nieuwe invasieve uitheemse soorten te voorkomen.

\section{De EU 2050-visie}

Tegen 2050 moet de biodiversiteit van de Europese Unie en de ecosysteemdiensten die daardoor worden geleverd - het natuurlijk kapitaal van de Unie - vanwege de intrinsieke waarde van de 
biodiversiteit en de essentiële bijdrage ervan aan het welzijn van de mens en de economische welvaart, worden beschermd, gewaardeerd en naar behoren hersteld, en wel zo dat catastrofale veranderingen ten gevolge van het biodiversiteitsverlies worden voorkomen (Europese Unie, 2011).

\section{7 (Inter)nationale actoren}

\section{Europees Milieuagentschap (EEA)}

Het EEA (European Environment Agency) is een agentschap van de Europese Unie. Het heeft als taak betrouwbare en onafhankelijke informatie over het milieu te verstrekken. Het EEA ijvert voor duurzame ontwikkeling door het milieu in Europa beduidend en meetbaar beter te helpen maken. Het EEA doet dit door gerichte, relevante en betrouwbare informatie te verstrekken aan beleidsmakers en het grote publiek (https://www.eea.europa.eu/).

\section{Internationale Raad voor Onderzoek der Zee (ICES)}

ICES (International Council for the Exploration of the Sea) coördineert en bevordert het mariene onderzoek op het gebied van oceanografie, het zeemilieu, het ecosysteem en de (exploitatie van de) visbestanden in de Noordelijke Atlantische Oceaan. ICES is een netwerk van meer dan 1.600 wetenschappers van tweehonderd instituten. Die zijn door een intergouvernementele overeenkomst met elkaar verbonden en geven daarmee een meerwaarde aan de afzonderlijke nationale onderzoeksinspanningen.

\section{OSPAR}

Het OSPAR-Verdrag vormt een overkoepelend juridisch kader voor de bescherming van het mariene milieu in het noordoostelijke deel van de Atlantische oceaan, hetgeen tevens de Noordzee omvat. Er zijn 16 OSPAR lidstaten langs de westkust en binnenzeeën van Europa en de EU die samenwerken om de Noordoostelijke Atlantische oceaan te beschermen waarbij het voorzorgsprincipe en de ecosysteembenadering centraal staan. Zo wordt bijvoorbeeld monitoring en beoordeling van de Noordzee door de verschillende lidstaten afgestemd onder de OSPAR werkgroep JAMP (Joint Assessment \& Monitoring Programme). Ook is in 2000 (OSPAR, 2000), 2010 (OSPAR, 2010) en 2017 (OSPAR 2017) de toestand van de Noordoost Atlantische oceaan, waaronder de Noordzee, gerapporteerd.

\section{Internationale Maritieme Organisatie (IMO)}

De IMO is een organisatie van de Verenigde Naties met als voornaamste taak het ontwikkelen en onderhouden van een duidelijk regulerend kader binnen de scheepvaartindustrie, onder meer voor veiligheids- en milieuaangelegenheden, wettelijke aangelegenheden, technische samenwerking, maritieme veiligheid en voor de bevordering van de efficiëntie in de scheepvaart. Maatregelen met betrekking tot de scheepvaart vallen binnen het kader van de IMO.

\section{Interdepartementaal Directeuren Overleg Noordzee (IDON)}

Alle ministeries met taken en verantwoordelijkheden op de Noordzee werken samen in het Interdepartementaal Directeuren Overleg Noordzee (IDON). Dit orgaan coördineert de ontwikkeling van beleid en bereidt besluiten voor over het beheer van de Noordzee. De coördinerende rol van IDON zorgt ervoor dat de ministeries beleid maken vanuit één gezamenlijke visie op de toestand, het gebruik en de verdere ontwikkeling van het Noordzeegebied. De opgaven die daaruit voortkomen voor het beheer van de Noordzee stemmen zij in IDON af. Zo kan het rijk als één overheid zijn rol waarmaken in het duurzaam vormgeven van het huidig en toekomstig gebruik van de Noordzee. In IDON werken samen: de ministeries van Infrastructuur en Milieu (voorzitter), Economische Zaken, Defensie, Financiën, Onderwijs, Cultuur en Wetenschap en de uitvoeringsorganisaties Rijkswaterstaat en Kustwacht (www.noordzeeloket.nl). 


\subsection{Beleidskaders voor de NatuurBalans Noordzee}

Voor de invulling van deze NatuurBalans Noordzee is ervoor gekozen dat de KRM leidend is. Reden is dat de KRM geacht wordt het meest complete beeld van de toestand van de Noordzee te geven met daarbij aandacht voor zowel de natuur zelf als ook de menselijke activiteiten en hun drukfactoren die die natuur beïnvloeden. Verder geldt dat verschillende elementen van de overige beleidskaders ook in de KRM terugkomen. Dit geldt bijvoorbeeld voor de voornaamste natuur-gerelateerde doelstellingen van het GVB (in KRM Descriptor 3-visbestanden) of die van de VHR (in KRM Descriptor 1Biodiversiteit). Ecosysteemdiensten krijgen in de KRM weinig aandacht maar omdat ze in de Biodiversiteit strategie en in het CLO wel expliciet genoemd worden is ervoor gekozen ze onderdeel te maken van de NatuurBalans Noordzee. 


\section{Beschrijving toestand van de Noordzee}

\subsection{Inleiding}

Zoals aangegeven is de KRM leidend geweest voor de structuur van deze NatuurBalans Noordzee. Dat betekent dat deze NatuurBalans Noordzee grotendeels is gebaseerd op KRM indicatoren. Het is zo opgezet dat de informatie die betrekking heeft op ieder van de KRM Descriptoren en criteria nog duidelijk als zodanig herkenbaar is. Waar relevant zijn ook CLO indicatoren opgenomen. Voor deze NatuurBalans Noordzee is de informatie opnieuw geordend in een structuur die duidelijk onderscheid maakt tussen de toestand van de natuur in het Noordzee ecosysteem en de menselijke activiteiten en hun drukfactoren (Tabel 4). Deze informatie wordt in dit hoofdstuk (Hoofdstuk 4) voor ieder van de ecosysteemcomponenten en drukfactoren apart beschreven waarna later (Hoofdstuk 5) die informatie weer op verschillende manieren geaggregeerd kan worden om zo tot het integraal perspectief voor de NatuurBalans Noordzee te komen. In Tabel 4 zijn de ecosysteemcomponenten en drukfactoren gecombineerd met activiteiten volgens het principe van de DPSIR-cyclus.

Tabel 4 De onderdelen van het Noordzee ecosysteem en de corresponderende KRM Descriptoren en Criteria. Deze zijn de basis voor de verschillende aggregaties waarop de integrale evaluatie (Hoofdstuk 5) voor de NatuurBalans Noordzee gebaseerd is. De elf descriptoren zijn: D1 Biodiversiteit; D2 Nietinheemse soorten; D3 Commerciële visbestanden; D4 Voedselweb; D5 Eutrofiering; D6 Bodemintegriteit; D7 Hydrografische eigenschappen; D8 Vervuilende stoffen; D9 Vervuilende stoffen in vis; D10 Zwerfvuil; D11 Energietoevoer, o.m. onderwatergeluid.

\begin{tabular}{|c|c|c|}
\hline \multicolumn{2}{|r|}{ Noordzee Ecosysteem } & KRM (Descriptoren en Criteria) \\
\hline \multirow{5}{*}{$\begin{array}{c}\text { Natuur: } \\
\text { Structuur en } \\
\text { functioneren }\end{array}$} & Zeezoogdieren & $\begin{array}{c}\text { D1C1，D1C2，D1C3，D1C4，D1C5， } \\
\text { D11C1 }\end{array}$ \\
\hline & Zeevogels & $\mathrm{D} 1 \mathrm{C} 2, \mathrm{D} 1 \mathrm{C} 3$ \\
\hline & $\begin{array}{l}\text { Vissen: Commerciële soorten en aspecten } \\
\text { van de vis gemeenschap }\end{array}$ & $\begin{array}{l}\mathrm{D} 1 \mathrm{C2}, \mathrm{D} 1 \mathrm{C} 3, \mathrm{D} 1 \mathrm{C} 4, \mathrm{D} 1 \mathrm{C} 5 \\
\mathrm{D} 3 \mathrm{C} 1, \mathrm{D} 3 \mathrm{C} 2, \mathrm{D} 4 \mathrm{C} 3\end{array}$ \\
\hline & $\begin{array}{l}\text { Zeebodem: Indicator soorten en aspecten } \\
\text { van de benthische gemeenschap }\end{array}$ & D4C1, D6C4, D6C5 \\
\hline & $\begin{array}{l}\text { Waterkolom: Aspecten van de zoöplankton } \\
\text { en fytoplankton gemeenschap }\end{array}$ & D1C6, D4C1, D4C2, D5C2 \\
\hline \multirow{8}{*}{$\begin{array}{c}\text { Menselijke } \\
\text { activiteiten } \\
\text { en hun } \\
\text { Drukfactoren }\end{array}$} & Niet-inheemse soorten & $\mathrm{D} 2 \mathrm{C} 1$ \\
\hline & Visserij: vangst en bijvangst & $\mathrm{D} 1 \mathrm{C} 1, \mathrm{D} 3 \mathrm{C} 1, \mathrm{D} 3 \mathrm{C} 2$ \\
\hline & Eutrofiering & D5C1, D5C2, D5C3, D5C5 \\
\hline & Verstoring en verlies zeebodem & $\mathrm{D} 6 \mathrm{C} 1, \mathrm{D} 6 \mathrm{C} 2, \mathrm{D} 6 \mathrm{C3}$ \\
\hline & Hydrografische eigenschappen & D7C1, D7C2 \\
\hline & Vervuilende stoffen & D8C1, D8C2, D8C3, D9C1 \\
\hline & Zwerfvuil & D10C1, D10C2, D10C3 \\
\hline & Onderwater geluid & $\mathrm{D} 11 \mathrm{C} 1, \mathrm{D} 11 \mathrm{C} 2$ \\
\hline
\end{tabular}

Per onderdeel worden steeds drie punten beschreven:

- Huidige toestand en trend;

- Belangrijke drukfactoren en activiteiten;

- Milieudoelen en beleidsmaatregelen.

De beschrijving van de huidige toestand is grotendeels gebaseerd op de KRM beoordeling, indien relevant aangevuld met informatie vanuit het CLO en overige relevante bronnen. Ook de milieudoelen en beleidsmaatregelen zijn gebaseerd op de KRM. De milieudoelen dienen de voortgang tot GMT te begeleiden en de maatregelen geven daar uitvoering aan.

Voor de belangrijkste drukfactoren en activiteiten is gebruik gemaakt van de risico scores die zijn geschat voor de internationale Noordzee (Piet et al., 2018; Borgwardt et al., 2019). Hierbij zijn de 
drukfactoren en activiteiten met de hoogste risico scores als belangrijkste geselecteerd. Daarbij moet worden opgemerkt dat wijdverspreide, continue en veelvoorkomende activiteiten zoals visserij en scheepvaart, relatief hoog scoren in de analyse van Piet et al. (2018) en Borgwardt et al. (2019). Dit is een mogelijk artefact in de analyse dat door betere modellen (zie ModellenVisie Noordzee: Piet et al., in prep.) waarschijnlijk geëlimineerd kan worden. Voor de toepassing in deze studie zijn er wel alvast enige aanpassingen gedaan om de risicoschatting meer geschikt te maken voor deze rapportage (o.a. meer specifiek gericht op de Nederlandse Noordzee met betrekking tot de ruimtelijke omvang en intensiteit).

Voor de belangrijkste drukfactoren en activiteiten is ook gebruik gemaakt van bijlage 4 uit het KRM rapport deel II (monitoringprogramma: Ministerie van IenM en EZ, 2014). Hierin staat met welke drukfactoren en daaraan gerelateerd gebruik rekening moet worden gehouden bij de beoordeling van de gegevens uit het monitoringprogramma. Aan de hand daarvan is een schematisch overzicht gemaakt van de relaties tussen de onderdelen van het Noordzee ecosysteem en de drukfactoren en activiteiten (Figuur 8). De relevante relaties worden steeds per onderdeel aan de hand van een selectie uit het onderstaand schema getoond.

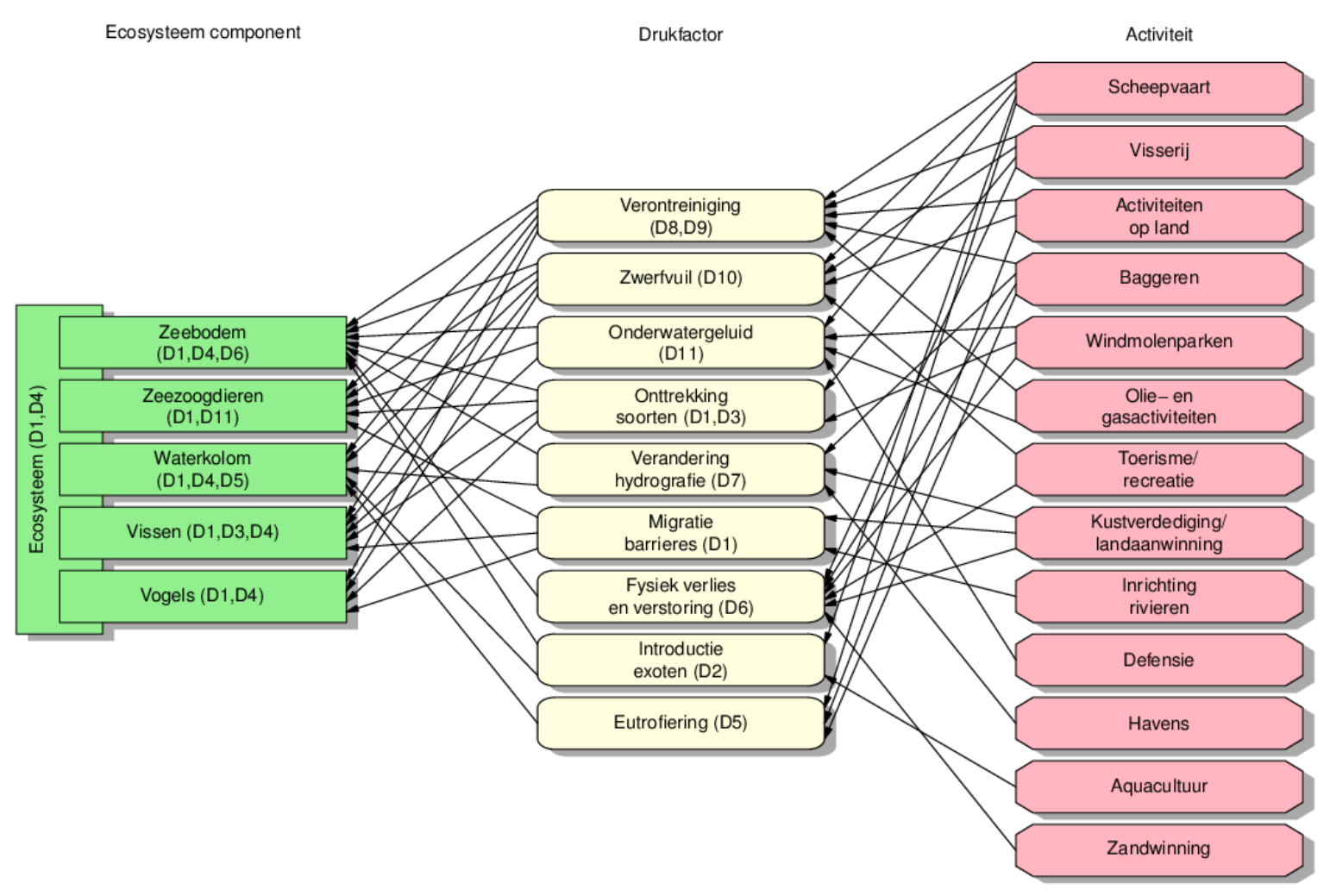

Figuur 8 De onderdelen van het Noordzee ecosysteem en de corresponderende KRM Descriptoren die worden beïnvloed door diverse menselijke activiteiten. De relaties zijn zoveel mogelijk gebaseerd op informatie vanuit de Nederlandse KRM (Ministerie van IenM en EZ, 2014; Ministerie van I\&W en LNV, 2018). D1 Biodiversiteit; D2 Niet-inheemse soorten; D3 Commerciële visbestanden; D4 Voedselweb; D5 Eutrofiering; D6 Bodemintegriteit; D7 Hydrografische eigenschappen; D8 Gevaarlijke stoffen; D9 Gevaarlijke stoffen in vis; D10 Zwerfvuil; D11 Energietoevoer, o.m. onderwatergeluid.

\subsection{Natuur: Structuur en functioneren}

\subsubsection{Zeezoogdieren}

\section{Huidige toestand en trend}

De Goede Milieu Toestand (GMT) voor zeezoogdieren is bereikt wanneer populatiedichtheden en demografie van populaties van zeezoogdieren duiden op gezonde populaties. Dit is uitgewerkt in 6 
criteria, die betrekking hebben op: de populatieomvang van de grijze- en gewone zeehond en bruinvis; de verspreiding van gewone zeehond en bruinvis; limiet voor bijvangst; limiet voor impulsgeluid; limiet voor reproductieafname grijze zeehond; en de mate waarin het areaal en de kwaliteit van leefgebieden (Habitatrichtlijn (HR)) van zeezoogdieren zich ontwikkelen (zie Tabel 5).

De GMT voor zeezoogdieren is nog niet gehaald. Wel is er een verbetering van de toestand waarneembaar (Ministerie van I\&W en LNV, 2018). Onder de tabel wordt meer toelichting gegeven.

Tabel 5 Toestandsbeoordeling zeezoogdieren (gebaseerd op de KRM beoordeling door Ministerie van I\&W en LNV, 2018). De status geeft aan of de goede milieutoestand (GMT) is gehaald (goed), niet gehaald (niet goed), nog niet bekend is vanwege bijvoorbeeld het ontbreken van vastgestelde grenswaarden/streefwaarden (onbekend). Voor sommige criteria is geen status gerapporteerd (-)

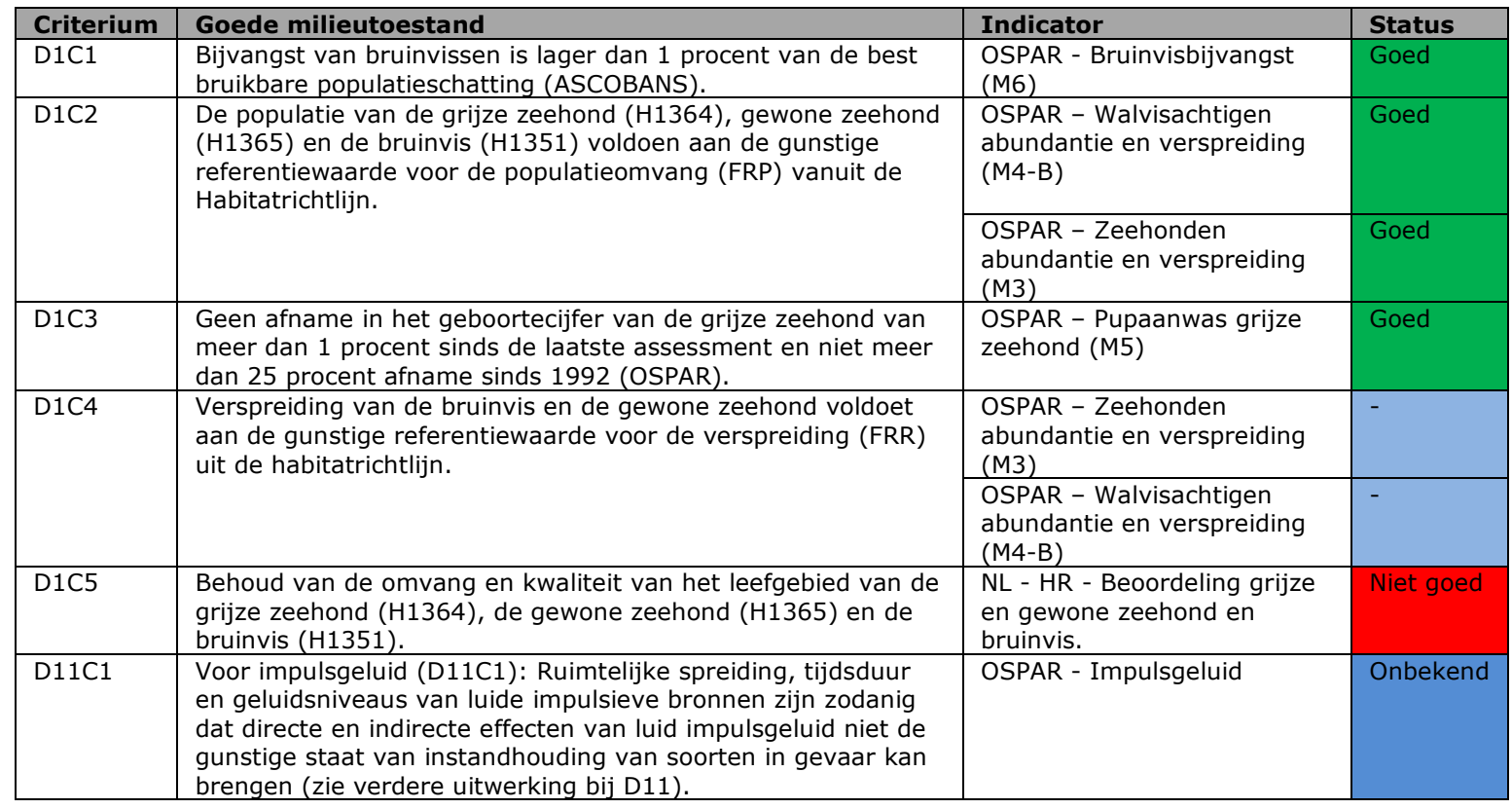

De geschatte jaarlijkse bijvangst van bruinvis in de Noordzee ligt onder de gestelde limiet van $1 \%$ van de populatie (Tabel 6). Dit is een schatting gebaseerd op waarnemingen uit 2013 (bijvangst) en 2016 (omvang populatie).

Tabel 6 OSPAR indicator bijvangst bruinvis: Schattingen bijvangst bruinvis in de Noordzee (OSPAR, 2017). cv: coefficient of variation (de relatieve standaard deviatie)

\begin{tabular}{ll} 
Parameter & Waarde \\
\hline Totaal aantal jaarlijkse bruinvis bijvangst (95\% zekerheidsgrens) & $1.235-1.990(2013)$ \\
Bruinvis abundantie obv SCANS-III survey & $345.400(\mathrm{cv} 0,18)(2016)$ \\
Jaarlijkse bijvangst als percentage van de abundantie & $0,36-0,58 \%$
\end{tabular}

Het aantal bruinvissen in de Noordzee is stabiel (OSPAR, 2017; Ministerie van I\&W en LNV, 2018). De verspreiding van de bruinvis is aanzienlijk verschoven sinds 1994 (Figuur 9). De data van de SCANS III survey (2016) zijn nog niet geanalyseerd maar de resultaten laten een soortgelijke verspreiding zien als in 2005 waaruit blijkt dat de verschuiving zich lijkt te handhaven (Figuur 10). 

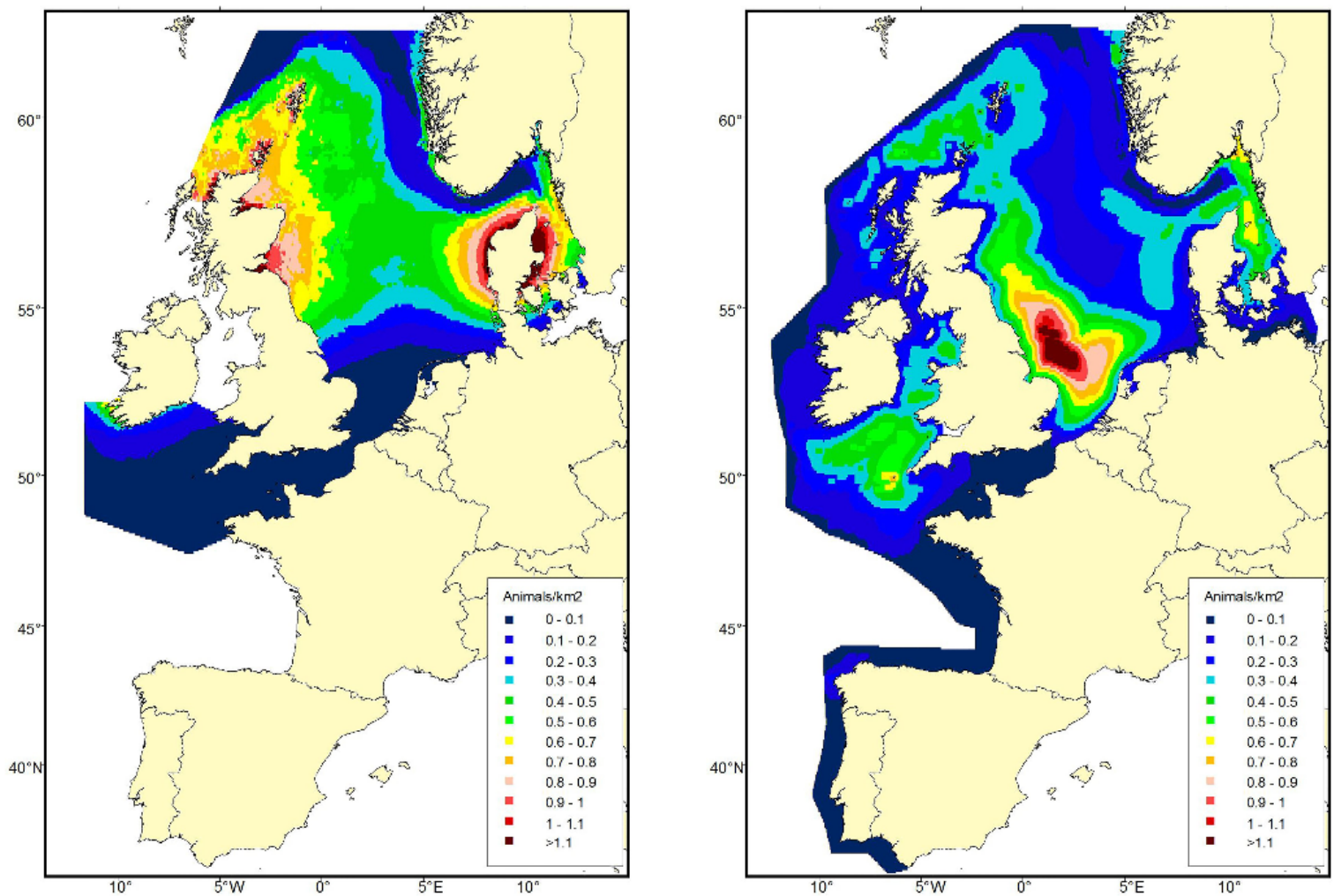

Figuur 9 OSPAR indicator verspreiding cetaceans; de voorspelde dichtheid van bruinvissen gebaseerd op de SCANS data uit 1994 (links) en op de SCANS II data uit 2005 (rechts) (OSPAR, 2017). 


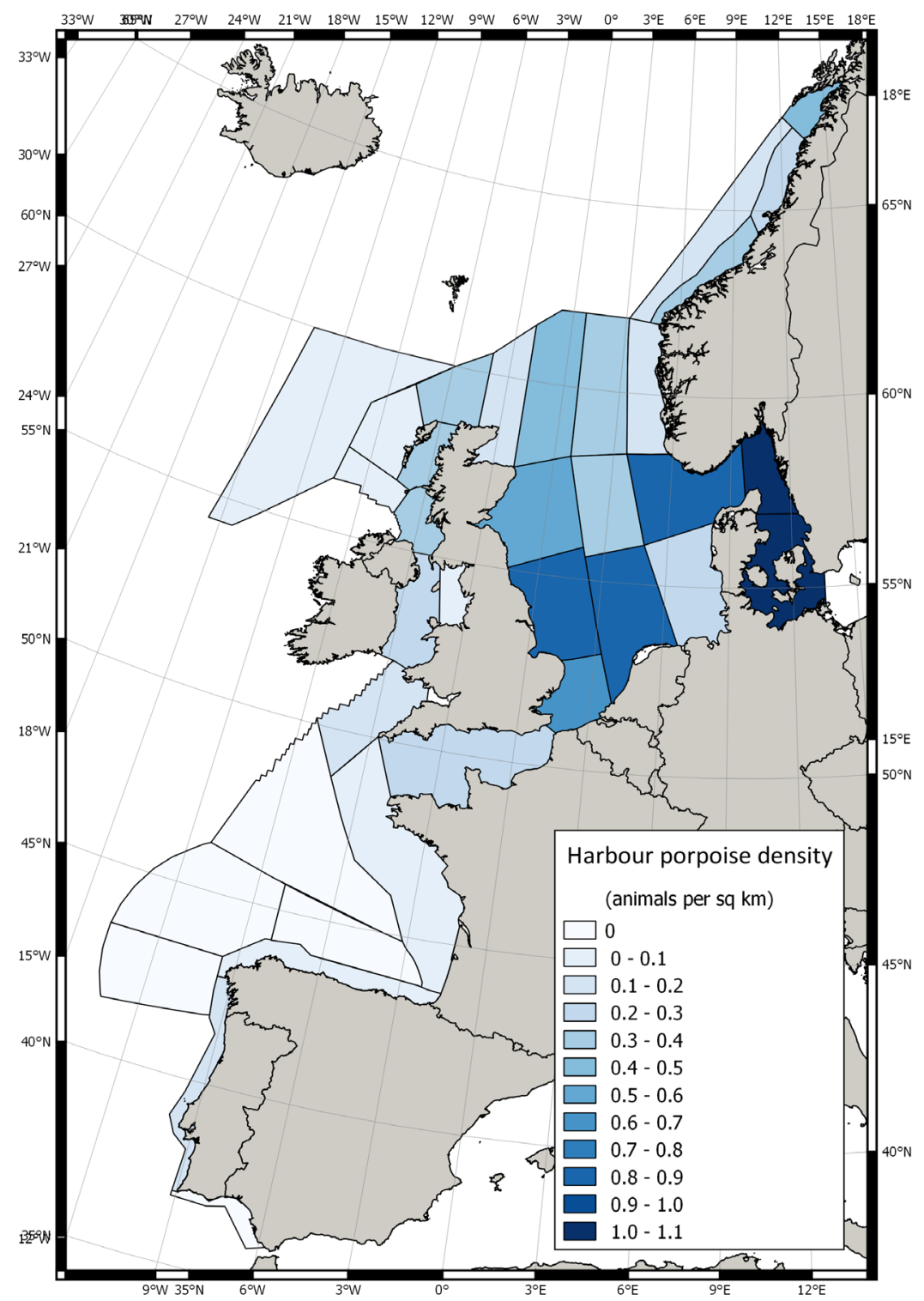

Figuur 10 Voorspelde dichtheid van bruinvissen gebaseerd op de SCANS III data uit 2016 (https://synergy.st-andrews.ac.uk/scans3/2017/05/01/first-results-are-in/).

Het aantal grijze- en gewone zeehonden is toegenomen (OSPAR, 2017 en Figuur 11). Ook is er een stijging van het jaarlijks aantal pups van de grijze zeehond (Figuur 12). Door het stoppen van de jacht op zeehonden groeien de populaties. Het is niet bekend wat de draagkracht van de Noordoost Atlantische Oceaan is voor zeehonden. Verwacht wordt dat de groei van de populaties zal afnemen naarmate de maximale draagkracht wordt benaderd. Door toename van grijze zeehonden kan de populatie gewone zeehonden door competitie onder druk komen te staan. Ook kan de abundantie en verspreiding mogelijk negatief worden beïnvloed door antropogene drukfactoren zoals verontreiniging en onderwatergeluid (OSPAR, 2017). 


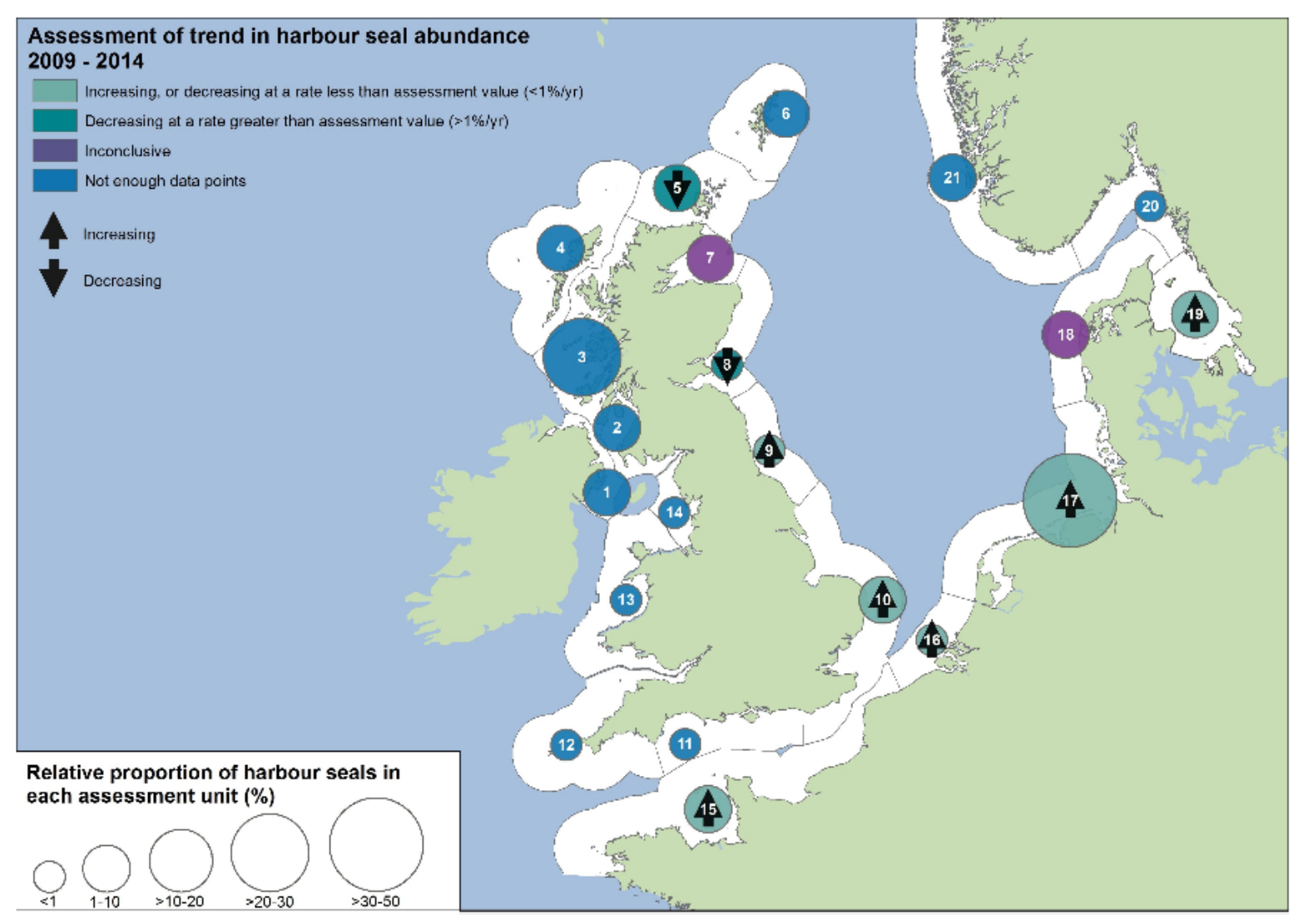

Figuur 11 OSPAR indicator Zeehonden abundantie en verspreiding; beoordeling van de recente verandering (2009-2014) in abundantie van de gewone zeehond (OSPAR, 2017). Het getal in elke cirkel refereert naar de beoordelingseenheid (Assessment Unit: AU). Het referentiejaar is 1992, maar in een aantal AUs is een later jaar gebruikt wat tussen haakjes staat aangegeven: 1. Northern Ireland (2002), 2. South-West Scotland (1996), 3. West Scotland (1997), 4. Western Isles, 5. North Coast \& Orkney (1993), 6. Shetland (1993), 7. Moray Firth (1994), 8. East Scotland (1997), 9. North-East England (1994), 10. South-East England (1995), 11. South England (1997), 12. South-West England (1997), 13. Wales (1997), 14. North-West England (1997), 15. French North Sea \& Channel Coast, 16. Belgium Coast and Dutch Delta (2003), 17. Wadden Sea, 18. Limfjorden, 19. Kattegat, 20. Northern Skagerrak and Oslo Fjord (1999), 21. Norwegian West Coast, south of 62N (1999). 


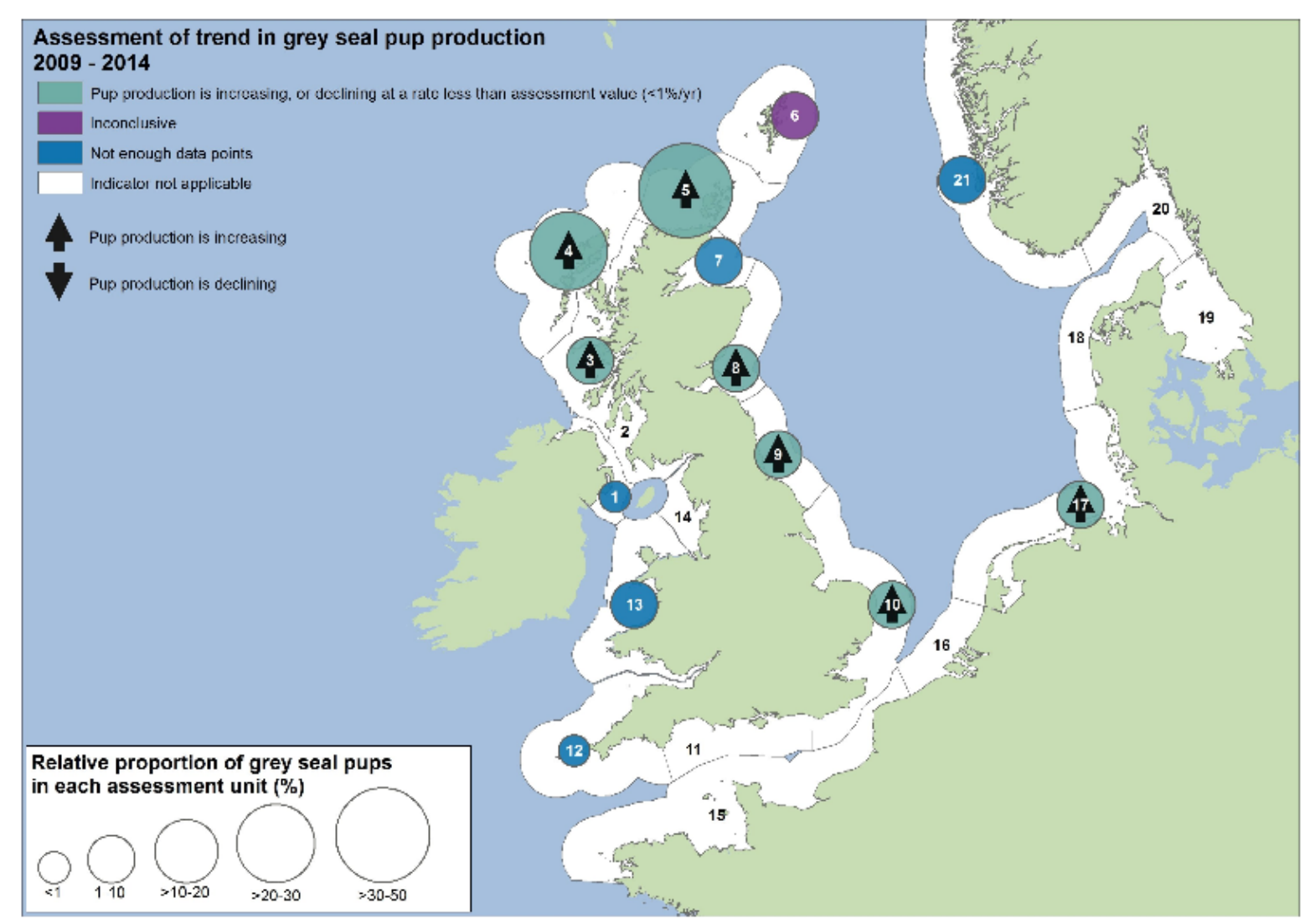

Figuur 12 OSPAR indicator pup productie grijze zeehond: de verandering in pup productie tijdens de periode 2009-2014, beoordeeld ten opzichte van een maximale afname van 1\% per jaar (OSPAR, 2017). Het getal in elke cirkel refereert naar de beoordelingseenheid (Assessment Unit: $A U$ ), zie Figuur 11.

Om de GMT voor zeezoogdieren te bereiken moet ook worden gezorgd dat de blootstelling aan onderwatergeluid binnen acceptabele grenzen blijft. Daarvoor wordt de OSPAR indicator voor impulsgeluid gehanteerd. Er is echter nog geen limiet ontwikkeld zodat het nog onbekend is of het criterium is gehaald. Er wordt in OSPAR verband nog gewerkt aan het verder ontwikkelen van deze indicator. Onderwatergeluid wordt niet alleen met betrekking tot D1 (Biodiversiteit) beoordeeld, wat hier wordt beschreven in relatie tot de mogelijke verstoring van zeezoogdieren, maar wordt ook als drukfactor beoordeeld binnen de KRM onder D11 (Energietoevoer), zie paragraaf 4.3.8.

Ook wordt gekeken naar de beoordeling van de zeezoogdieren (grijze- en gewone zeehond en bruinvis) in het kader van de HR. De staat van instandhouding van de grijze zeehond en de bruinvis is matig ongunstig vanwege de kwaliteit van het leefgebied (Ministerie van I\&W en LNV, 2018). Dit betreft echter nog de HR rapportage uit 2013 (http://cdr.eionet.europa.eu/Converters/nl/eu/art17/). Voor de grijze zeehond is de matige kwaliteit van het leefgebied gerelateerd aan onvoldoende ligplaatsen langs de kust voor jongen die nog niet kunnen zwemmen. Menselijke verstoring heeft een negatieve invloed op het aantal dieren op een ligplaats. Door het sluiten van gebieden kunnen de belangrijkste ligplaatsen voor het jongen en verharen worden beschermd. Ondanks de groei van de populatie grijze zeehonden is de totale oppervlakte aan beschermde gebieden in de Waddenzee sinds omstreeks 2009 vrijwel onveranderd gebleven (Cremer et al., 2017). De situatie lijkt dus nog niet verbeterd. Onderzoek naar de factoren die de ligplaatskeuze van de zeehonden voor verharing en reproductie bepalen, zou de bescherming van de beide zeehondensoorten kunnen verbeteren en efficiënter maken (Cremer et al., 2017).

Voor de bruinvis was de matige kwaliteit van het leefgebied voornamelijk gerelateerd aan visserij (bijvangst). Inmiddels is onderzoek naar bijvangst van bruinvissen door de Nederlandse commerciële staandwant visserij (een van de belangrijkste aanbevelingen van het soortbeschermingsplan) afgerond (Scheidat et al., 2018). De bijvangst door de Nederlandse commerciële staandwant visserij blijkt gering, met een jaarlijkse sterfte van 0.05 tot $0.07 \%$ van de Nederlandse bruinvispopulatie (Scheidat et al., 2018). 


\section{Belangrijke drukfactoren en activiteiten}

De belangrijkste drukfactoren en activiteiten die bijdragen aan het totaal risico voor zeezoogdieren, die zijn geïdentificeerd aan de hand van de CEA, zijn:

- Zwerfvuil door o.a. visserij (o.a. spooknetten), toerisme en recreatie;

- Toevoer van stoffen door o.a. scheepvaart, havens, toerisme en recreatie, activiteiten op land (waterzuivering), olie- en gasactiviteiten;

- Botsing door o.a. scheepvaart, toerisme en recreatie en visserij;

- Barrière voor soortsbewegingen door o.a. windparken, militaire activiteiten, sluizen, staandwantvisserij.

Bij de Nederlandse KRM wordt ook uitgegaan van zwerfvuil, de toevoer van stoffen (verontreiniging) en onttrekking van soorten als belangrijke drukfactoren, terwijl botsing niet is geïdentificeerd als belangrijke drukfactor, zie Figuur 13. Het omgekeerde geldt voor onderwatergeluid. De belangrijkste activiteiten vanuit de KRM komen grotendeels overeen met de activiteiten die zijn geïdentificeerd aan de hand van de CEA.

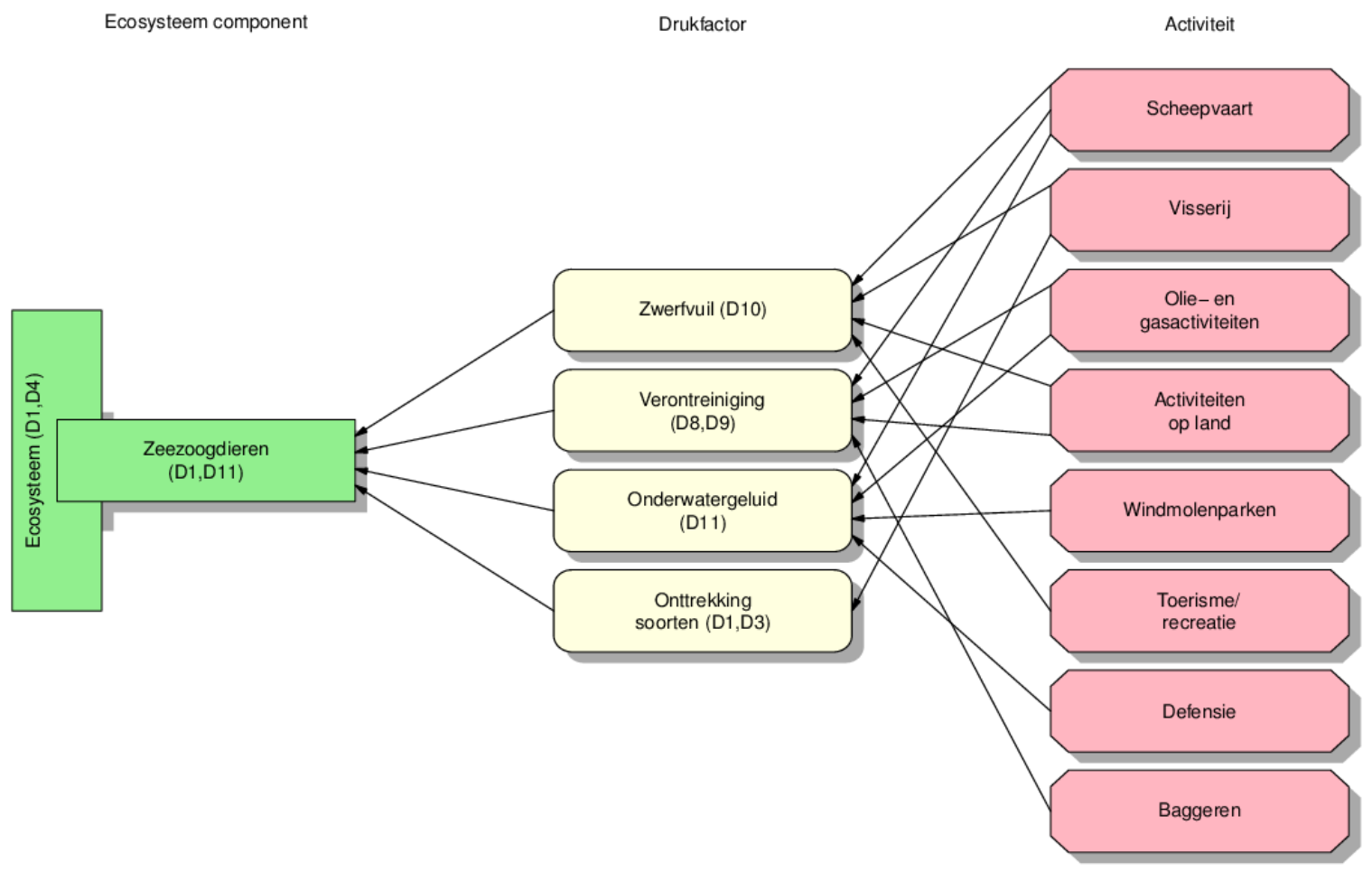

Figuur 13 Zeezoogdieren als onderdeel van het Noordzee ecosysteem en de belangrijkste drukfactoren en activiteiten die invloed daarop hebben. De relaties zijn zoveel mogelijk gebaseerd op informatie vanuit de Nederlandse KRM (Ministerie van IenM en EZ, 2014; Ministerie van I\&W en LNV, 2018). D1 Biodiversiteit; D2 Niet-inheemse soorten; D3 Commerciële visbestanden; D4 Voedselweb; D5 Eutrofiering; D6 Bodemintegriteit; D7 Hydrografische eigenschappen; D8 Gevaarlijke stoffen; D9 Gevaarlijke stoffen in vis; D10 Zwerfvuil; D11 Energietoevoer, o.m. onderwatergeluid.

\section{Milieudoelen en beleidsmaatregelen}

De milieudoelen om de voortgang tot GMT voor zeezoogdieren te begeleiden zijn (Ministerie van I\&W en LNV, 2018):

- D1T2: herstel van rust voor zeezoogdieren en vogels door vermindering van visserij op de Vlakte van de Raan en in de Noordzeekustzone (in het kader van het VIBEG-akkoord).

- D1T3: realiseren van instandhoudingsdoelstellingen voor habitattypen en soorten in de Natura 2000-gebieden op zee (VHR).

- D1T4: uitvoering van mitigerende maatregelen in kader van het Bruinvisbeschermingsplan van 2012, waaronder:

○ bijvangstmonitoring en onderzoek naar toepassing mitigerende maatregelen (pingers) 
- voorkomen of verminderen van schadelijke effecten van onderwatergeluid op bruinvispopulaties (Wet natuurbescherming, mede op basis van het Kader Ecologie en Cumulatie).

- verder onderzoek naar de effecten rond bouw en exploitatie van windparken op zee op de bruinvispopulaties (in kader van Wozep).

- D1T8: verder onderzoek naar cumulatieve effecten in OSPAR-verband.

- D4T1: ontwikkelen en testen van regionale beoordelingsmethoden die in de toekomst gebruikt kunnen worden voor een beoordeling van de status van voedselwebben (ook relevant voor de andere ecosysteem onderdelen).

Selectie van maatregelen uit het programma van maatregelen (2015), zoals aangegeven door het Ministerie van I\&W en LNV (2018):

- $\quad$ uitvoeren Bruinvisbeschermingsplan;

- beperken bijvangst en andere activiteiten in Natura 2000-gebieden;

- implementatie OSPAR-lijst bedreigde soorten;

- $\quad$ vergunningvereisten bij grootschalige ingrepen; zie paragraaf 0 'Energietoevoer'.

In de Mariene Strategie (Ministerie van I\&W en LNV, 2018) is geconcludeerd dat het bestaand beleid mogelijk niet voldoet om de GMT voor de biodiversiteit van zeezoogdieren te behalen. Dit betekent dat er mogelijk aanvullend beleid noodzakelijk is. Ook is er een kennisopgave met betrekking tot cumulatieve effecten (Ministerie van I\&W en LNV, 2018).

\subsubsection{Zeevogels}

\section{Huidige toestand en trend}

De GMT voor vogels is bereikt wanneer populatiedichtheden en demografie van populaties van vogels duiden op gezonde populaties. Dit is uitgewerkt in 3 verschillende criteria, waarbij getoetst wordt aan de populatieomvang, het broedsucces en de EU Vogelrichtlijn (VR), zie Tabel 7. De GMT voor vogels is nog niet gehaald. Voor broedvogels en broedsucces is er zelfs sprake van achteruitgang (Ministerie van I\&W en LNV, 2018). Voor wat betreft het behalen van de VR doelstelling wordt door het Ministerie van I\&W en LNV (2018) geen uitspraak gedaan, aangezien er in 2019 zal worden gerapporteerd over de mate van doelbereik over de periode $2013-2018^{1}$.

Tabel 7 Toestandsbeoordeling zeevogels (gebaseerd op de KRM beoordeling door Ministerie van I\&W en LNV, 2018). De status geeft aan of de goede milieutoestand is gehaald (goed), niet gehaald (niet goed), nog niet bekend is vanwege bijvoorbeeld het ontbreken van vastgestelde grenswaarden/streefwaarden (onbekend). Voor sommige criteria is geen status gerapporteerd (-)

\begin{tabular}{|l|l|l|l|}
\hline Criteria & Goede milieutoestand & Indicator & Status \\
\hline D1C2 & $\begin{array}{l}\text { Voor elke functionele groep is de populatieomvang van ten } \\
\text { minste 75 procent van de soorten boven de drempelwaarde van } \\
1992 \text { (OSPAR beoordelingswaarde). }\end{array}$ & $\begin{array}{l}\text { OSPAR - Abundantie } \\
\text { zeevogels (Marine Bird } \\
\text { Abundance) }\end{array}$ & $\begin{array}{l}\text { Niet goed } \\
\text { Nopulaties van zeevogels moeten voldoen aan de landelijke } \\
\text { doelen vanuit de VR. }\end{array}$ \\
\hline D1C2 & $\begin{array}{l}\text { Voor iedere soort mag een gebrek aan broedsucces in niet meer } \\
\text { dan drie van zes jaar optreden (OSPAR-beoordelingswaarde) }\end{array}$ & $\begin{array}{l}\text { OSPAR - Broedsucces of } \\
\text { broedfalen zeevogels (Marine } \\
\text { Bird breeding success or } \\
\text { failure) }\end{array}$ \\
\hline
\end{tabular}

De populatieomvang van zeevogels in de Noordzee voldoet aan het gestelde doel, met uitzondering van de benthisch foeragerende groep (Tabel 8). Het broedsucces van zeevogels in de Zuidelijke Noordzee ligt onder het doel (zie Figuur 14). Alle soorten die regelmatig broedfalen vertoonden foerageren op kleine vis in oppervlaktewater terwijl soorten die in diepere wateren of nabij de zeebodem foerageren veel minder vaak broedfalen vertoonden. Dit verschil kan worden gerelateerd aan de beschikbaarheid van kleine vis dicht op het wateroppervlak (zoals zandspiering en sprot) die

\footnotetext{
${ }^{1}$ De Europese lidstaten zijn verplicht om eens in de zes jaar op grond van artikel 12 van de Europese Vogelrichtlijn en artikel 17 van de Europese Habitatrichtlijn te rapporteren over de maatregelen die zijn genomen en over de mate van doelbereik. Dit laatste is voor de Vogelrichtlijn de omvang en verspreiding van de populaties van inheemse vogelsoorten en voor de Habitatrichtlijn de staat van instandhouding van soorten (Annex II, IV en V van de Habitatrichtlijn) en habitattypen (Annex I van de Habitatrichtlijn). In 2019 moet worden gerapporteerd over de periode 2013-2018.
} 
typische prooien vormen voor verschillende oppervlaktewater-foeragerende vogelsoorten (OSPAR, 2017).

Tabel 8 OSPAR Marine Bird Abundance. Percentage van de beoordeelde soorten die een relatieve abundantie boven de drempelwaarde (abundantie in het jaar 1992) hadden per functionele groep in het Noorse deel van de Arctische wateren en de Keltische zee regio's in 2015 en in de internationale Noordzee in 2014 (OSPAR Intermediate Assessment 2017)

\begin{tabular}{|l|l|l|l|l|l|l|}
\hline \multicolumn{7}{|c|}{ Above assessment value $(\geq 75 \%)$} \\
\hline \multicolumn{7}{|c|}{ Below assessment value (<75\%) }
\end{tabular}

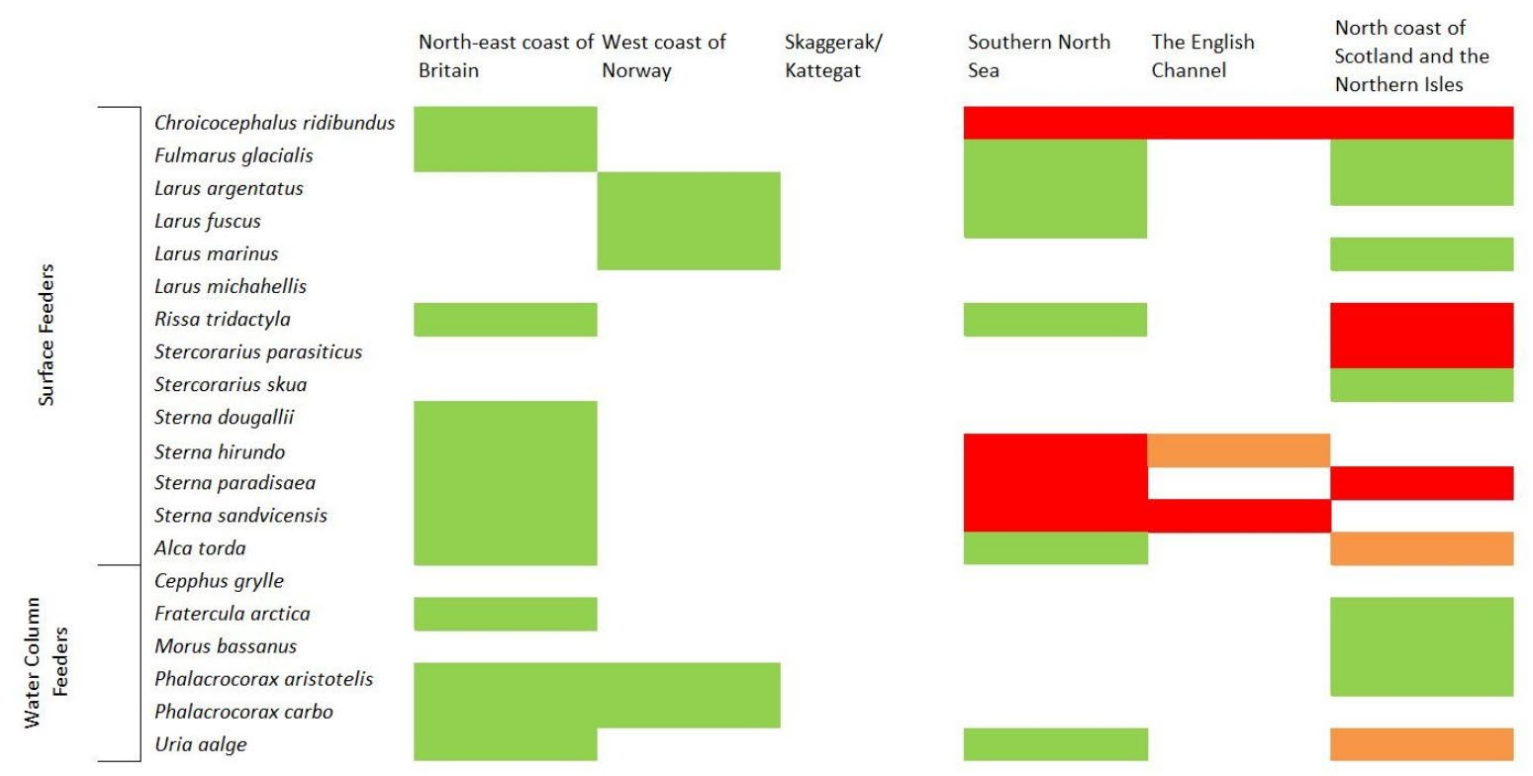

Figuur 14 OSPAR Marine Bird Breeding Success / Failure. Soort specifieke beoordeling van jaarlijks falen van broedkolonies in subdivisies van de internationale Noordzee (OSPAR Intermediate Assessment 2017). De soorten zijn gerangschikt per functionele groep. De kleuren geven het aantal jaar van wijdverspreid broedfalen aan, binnen de beoordeelde periode van 6 jaar (2010 tot 2015): groen = twee jaar of minder; oranje = drie jaar; rood = vier jaar of meer (OSPAR Intermediate Assessment 2017). 
Het CLO heeft twee indicatoren beschikbaar die informatie geven over zeevogelpopulaties (voornamelijk op basis van gegevens vanuit het MWTL-meetprogramma (vliegtuigtellingen), aangevuld met zeetrektellingen en het telprogramma van Sovon Vogelonderzoek Nederland):

- Aantallen zeevogels in de Noordzee kustzone;

- Aantallen zeevogels in de open Noordzee.

Waar de OSPAR indicatoren de gehele Noordzee beslaan, geven de CLO indicatoren de toestand binnen het Nederlandse deel van de Noordzee. Ook is er verschil tussen de groepen vogels: OSPAR maakt onderscheid tussen functionele groepen terwijl het CLO onderscheid maakt tussen soorten binnen- en buiten de kustzone. Binnen het Nederlandse deel van de Noordzee is een verschil tussen de populaties van de kustzone en de open Noordzee. Populaties van zeevogels in de Noordzee kustzone zijn gemiddeld stabiel gebleven (Figuur 15), terwijl populaties van zeevogels in de open Noordzee gemiddeld afnemen (Figuur 16).

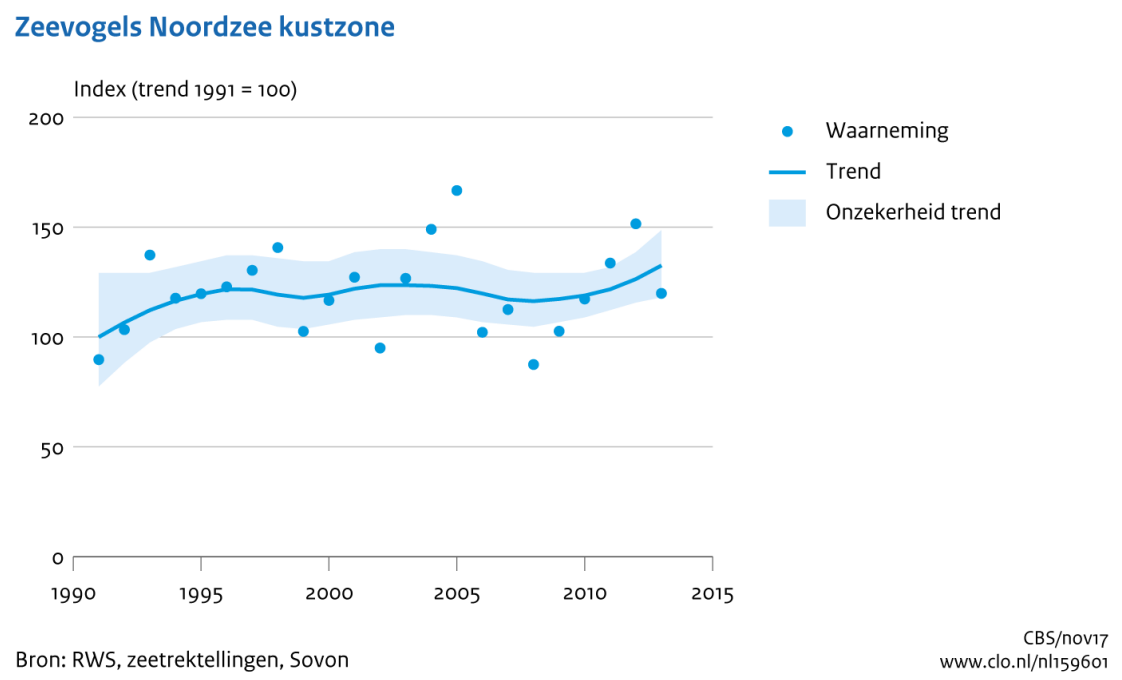

Figuur 15 Aantallen zeevogels in de Noordzee kustzone. Dit betreft een geïndexeerde waarde, waarbij het aantal in het jaar 1992 als referentiewaarde is genomen (CBS et al., 2017a).

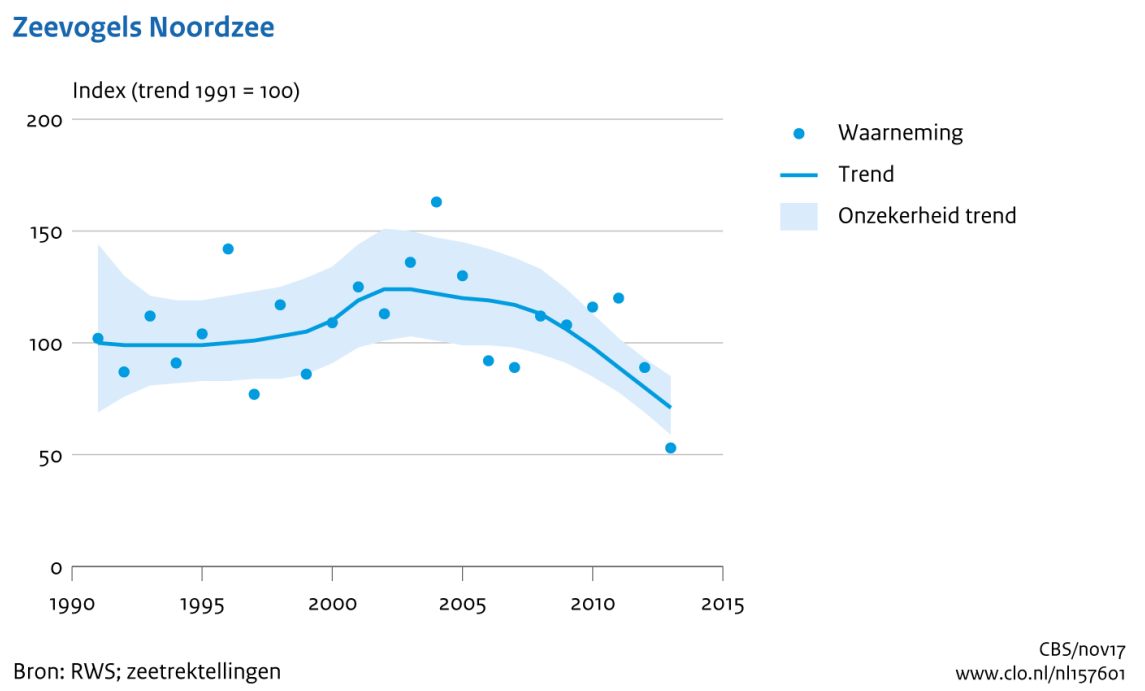

Figuur 16 Aantallen zeevogels in de Noordzee. Dit betreft een geïndexeerde waarde, waarbij het aantal in het jaar 1992 als referentiewaarde is genomen (CBS et al., 2017b).

Zeevogels (vooral meeuwensoorten) zullen waarschijnlijk in aantallen afnemen door het terugdringen van de discards in de visserij (Gemeenschappelijk Visserij Beleid) (Ministerie van I\&W en LNV, 2018).

\section{Belangrijke drukfactoren en activiteiten}

De belangrijkste drukfactoren en activiteiten die bijdragen aan het totaal risico voor zeevogels, die zijn geïdentificeerd aan de hand van de CEA, zijn: 
- Toevoer van stoffen door o.a. scheepvaart, havens, activiteiten op land (waterzuivering), toerisme en recreatie (sportvisserij), olie- en gasactiviteiten;

- Zwerfvuil door o.a. toerisme en recreatie en visserij;

- Onttrekking van soorten door o.a. visserij (bijvangst);

- Barrière voor soortsbewegingen door o.a. windparken, sluizen, staandwantvisserij;

- Introductie van microbiële pathogenen door o.a. visserij, havens, toerisme en recreatie.

Bij de Nederlandse KRM wordt ook uitgegaan van de toevoer van stoffen (verontreiniging) en onttrekking van soorten (inclusief sterfte door botsing) als belangrijke drukfactoren, terwijl verstoring niet is geïdentificeerd als belangrijke drukfactoren, zie Figuur 17. Het omgekeerde geldt voor zwerfvuil. De belangrijkste activiteiten vanuit de KRM komen grotendeels overeen met de activiteiten die zijn geïdentificeerd aan de hand van de CEA,

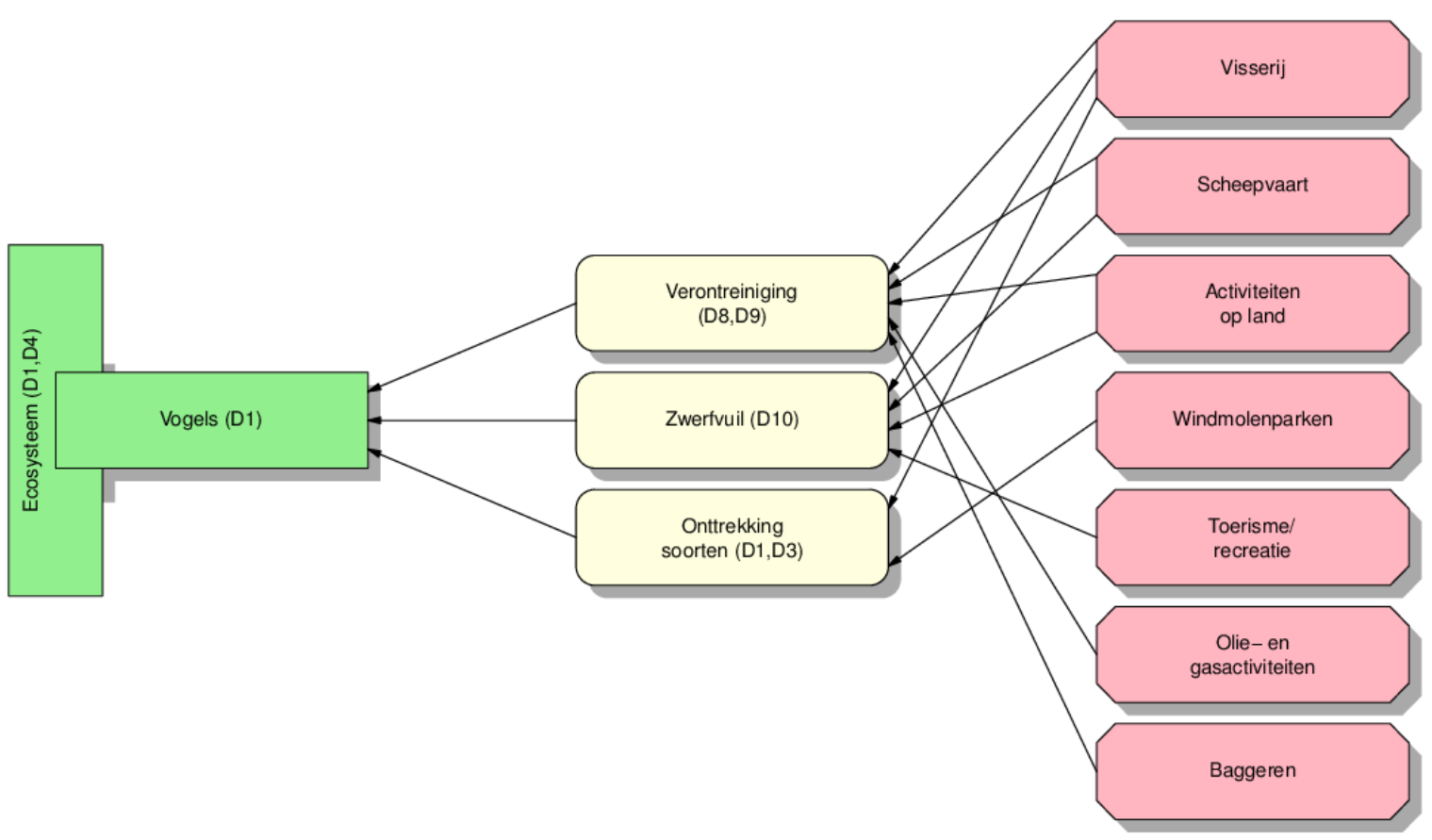

Figuur 17 Zeevogels als onderdeel van het Noordzee ecosysteem en de belangrijkste drukfactoren en activiteiten die invloed daarop hebben. De relaties zijn zoveel mogelijk gebaseerd op informatie vanuit de Nederlandse KRM (Ministerie van IenM en EZ, 2014; Ministerie van I\&W en LNV, 2018). D1 Biodiversiteit; D2 Niet-inheemse soorten; D3 Commerciële visbestanden; D4 Voedselweb; D5 Eutrofiering; D6 Bodemintegriteit; D7 Hydrografische eigenschappen; D8 Vervuilende stoffen; D9 Vervuilende stoffen in vis; D10 Zwerfvuil; D11 Energietoevoer, o.m. onderwatergeluid.

\section{Milieudoelen en beleidsmaatregelen}

De milieudoelen om de voortgang tot GMT voor vogels te begeleiden zijn (Ministerie van I\&W en LNV, 2018):

- D1T1: bijdragen aan de verdere ontwikkeling van de beoordeling van vogelpopulaties en het identificeren van de belangrijkste drukfactoren op regionaal niveau (OSPAR).

- D1T2: herstel van rust voor zeezoogdieren en vogels door vermindering van visserij op de Vlakte van de Raan en in de Noordzeekustzone (in het kader van het VIBEG-akkoord).

- D1T3: realiseren van instandhoudingdoelstellingen voor habitattypen en soorten in de Natura 2000-gebieden op zee (VHR).

- D1T7: monitoring vogelaanvaringen met windturbines in het kader van Wozep.

- D4T1: ontwikkelen en testen van regionale beoordelingsmethoden die in de toekomst gebruikt kunnen worden voor een beoordeling van de status van voedselwebben (ook relevant voor de andere ecosysteem onderdelen). 
Selectie van maatregelen uit het programma van maatregelen (2015), zoals aangegeven door het Ministerie van I\&W en LNV (2018):

- $\quad$ uitvoeren Bruinvisbeschermingsplan;

- beperken bijvangst en andere activiteiten in Natura 2000-gebieden;

- $\quad$ implementatie OSPAR-lijst bedreigde soorten. Vogelsoorten die relevant zijn voor Nederland op deze lijst is alleen de Drieteenmeeuw;

- $\quad$ vergunningvereisten bij grootschalige ingrepen zoals het Kader Ecologie en Cumulatie voor windenergie op zee.

In de Mariene Strategie (Ministerie van I\&W en LNV, 2018) is geconcludeerd dat het bestaand beleid mogelijk niet voldoet om de GMT voor de biodiversiteit van vogels te behalen. Dit betekent dat er mogelijk aanvullend beleid noodzakelijk is. Ook is er een kennisopgave met betrekking tot oorzaken achteruitgang en cumulatie en mogelijk mitigatie van effecten van windparken (Ministerie van I\&W en LNV, 2018).

\subsubsection{Vissen}

\section{Huidige toestand en trend}

Voor de beoordeling van de toestand van vissen zijn zowel commerciële soorten als aspecten van de gemeenschap van belang. De GMT voor vissen is bereikt wanneer de populatiedichtheden en demografie van populaties van vissen duiden op gezonde populaties. Dit is uitgewerkt in verschillende criteria, zie Tabel 9. De GMT voor vissen is niet nog gehaald.

Tabel 9 Toestandsbeoordeling vissen (gebaseerd op de KRM beoordeling door Ministerie van I\&W en $L N V$, 2018). De status geeft aan of de goede milieutoestand is gehaald (goed), niet gehaald (niet goed), nog niet bekend is vanwege bijvoorbeeld het ontbreken van vastgestelde grenswaarden/streefwaarden (onbekend).

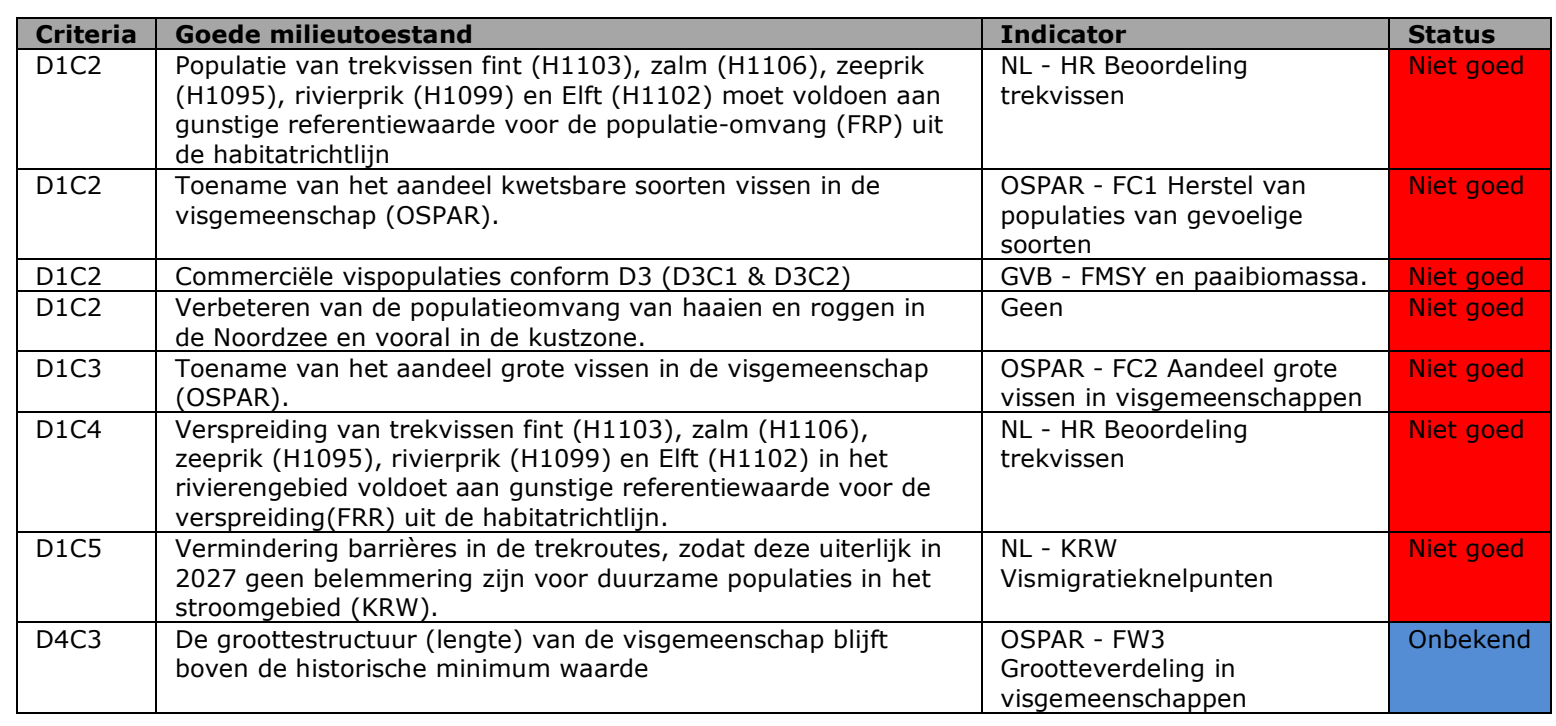

$\mathrm{Er}$ is nog geen herstel van populaties van gevoelige soorten en het aandeel grote vis is voor de Noordzee nog onder de grenswaarde (Figuur 18 en Figuur 19, respectievelijk). De afname van de abundantie van gevoelige vissoorten is gestopt, maar de grenswaarde is in de Noordzee nog niet bereikt (Figuur 18). Het aandeel grote vis neemt toe in de Noordzee (Figuur 19). Er is dus wel een verbetering van de toestand waarneembaar. 


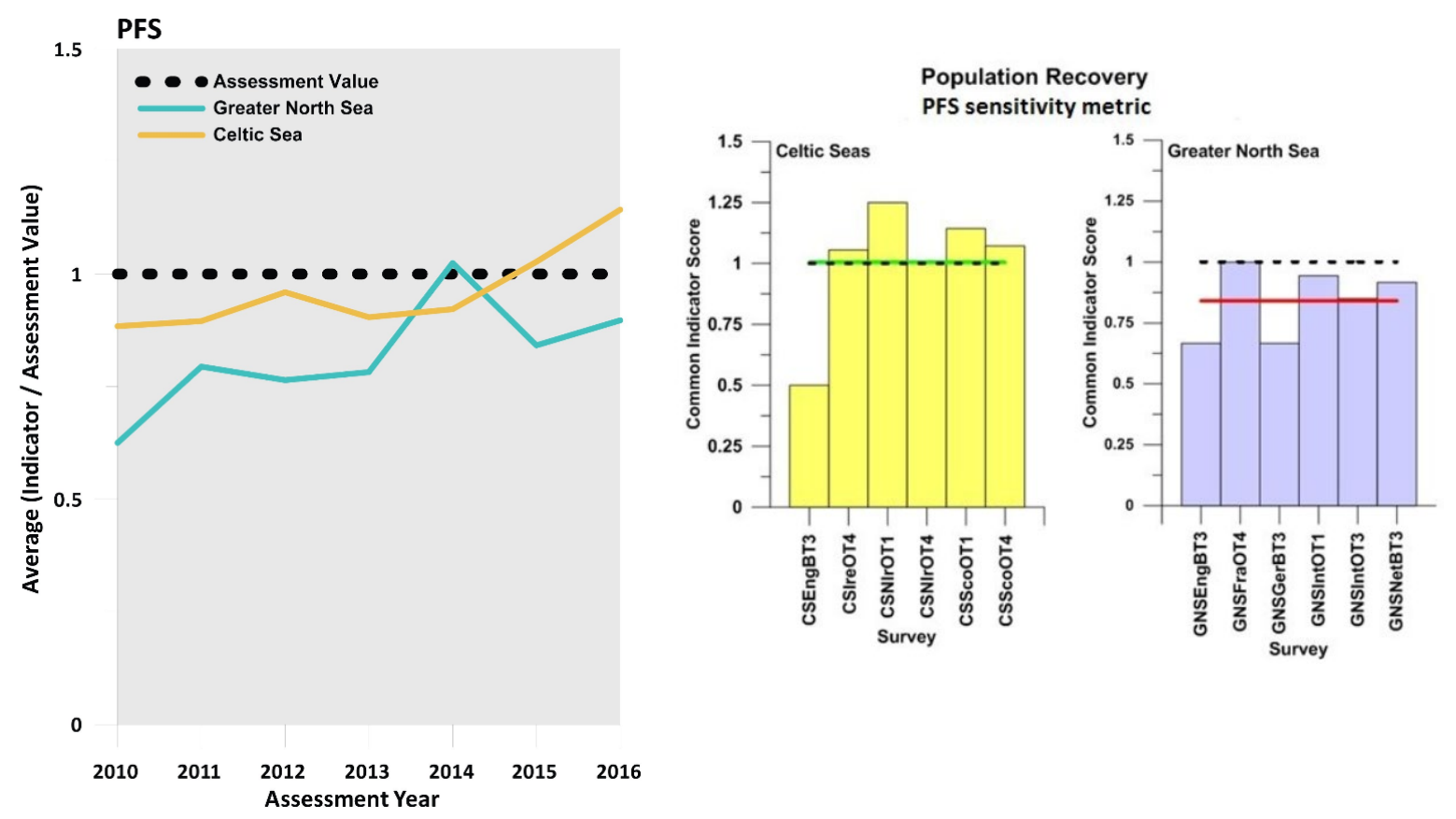

Figuur 18 OSPAR indicator FC1 Herstel van populaties van gevoelige soorten. Links een geïntegreerde waarde en rechts de scores per individuele vangstmethodiek. Bij een waarde groter dan 1 wordt voldaan aan het criterium (OSPAR, 2017).

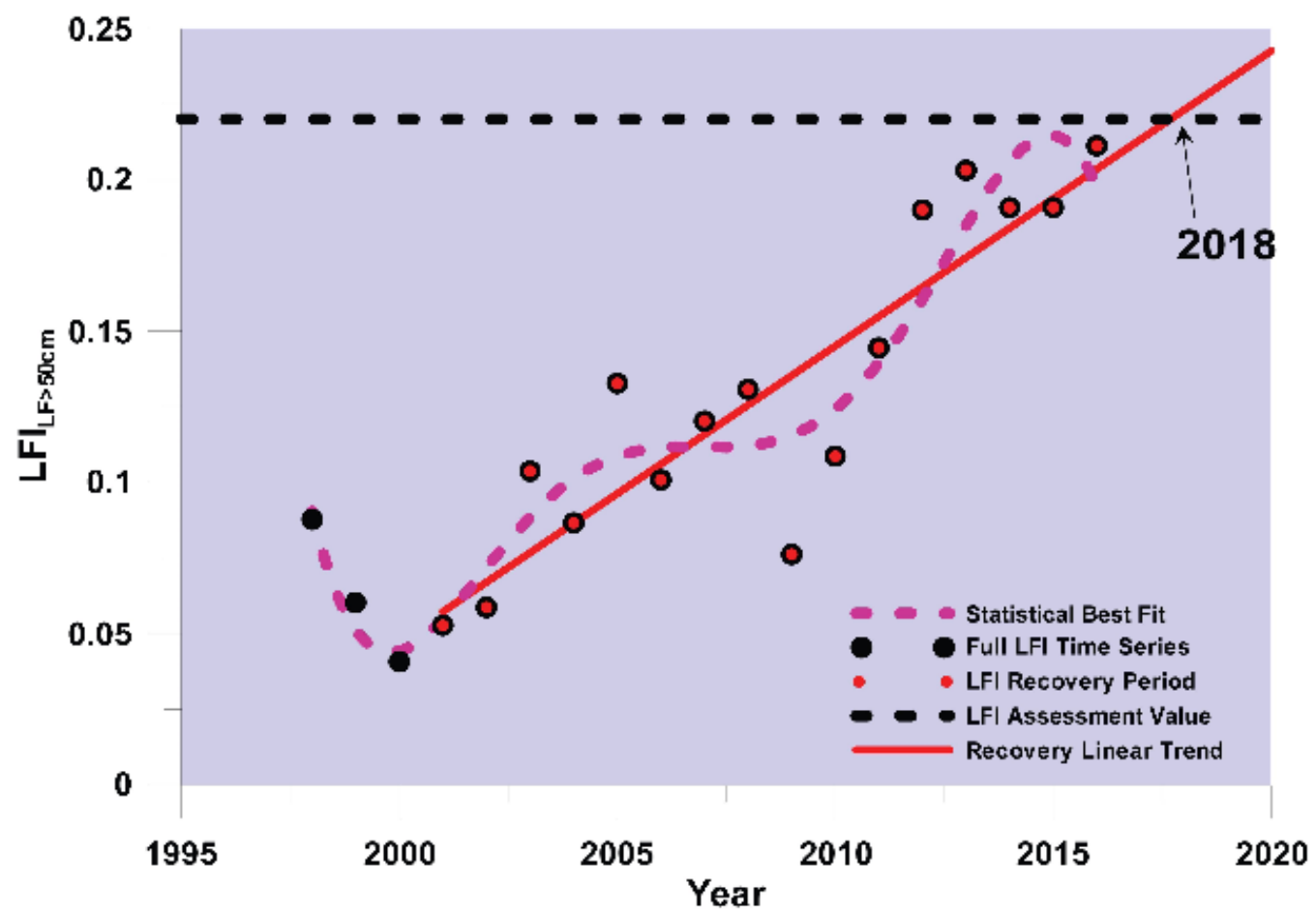

Figuur 19 OSPAR indicator voor het aandeel grote vis (Large Fish Index (LFI)). Deze LFI is gebaseerd op het derde kwartaal (juli tot september) internationale otter trawl survey in de gehele Noordzee. De LFI voldoet nog niet aan de grenswaarde, maar de trendanalyse suggereert dat deze in 2018 wel gehaald zou moeten worden (OSPAR, 2017).

In 2016 is het KRM haaien actieplan uitgebracht (Ministerie van EZ, 2016). (NB. Met 'haaien' wordt in het actieplan alle kraakbeenvissen bedoeld, inclusief roggen). De stand van haaien en roggen is nog steeds zorgelijk, maar laat wel eerste tekenen van herstel zien (Ministerie van I\&W en LNV, 2018; 
Figuur 20). De CLO indicator Roggen en haaien (Figuur 20) is gebaseerd op gegevens van de International Bottom Trawl Survey (IBTS) en de Beam Trawl survey (BTS), beschikbaar via de DATRAS database van ICES, van vijf inheemse soorten roggen en haaien (gevlekte rog, stekelrog, sterrog, hondshaai en doornhaai). De goede milieutoestand is als gevolg van kennisleemten niet te bepalen (Ministerie van I\&W en LNV, 2018).

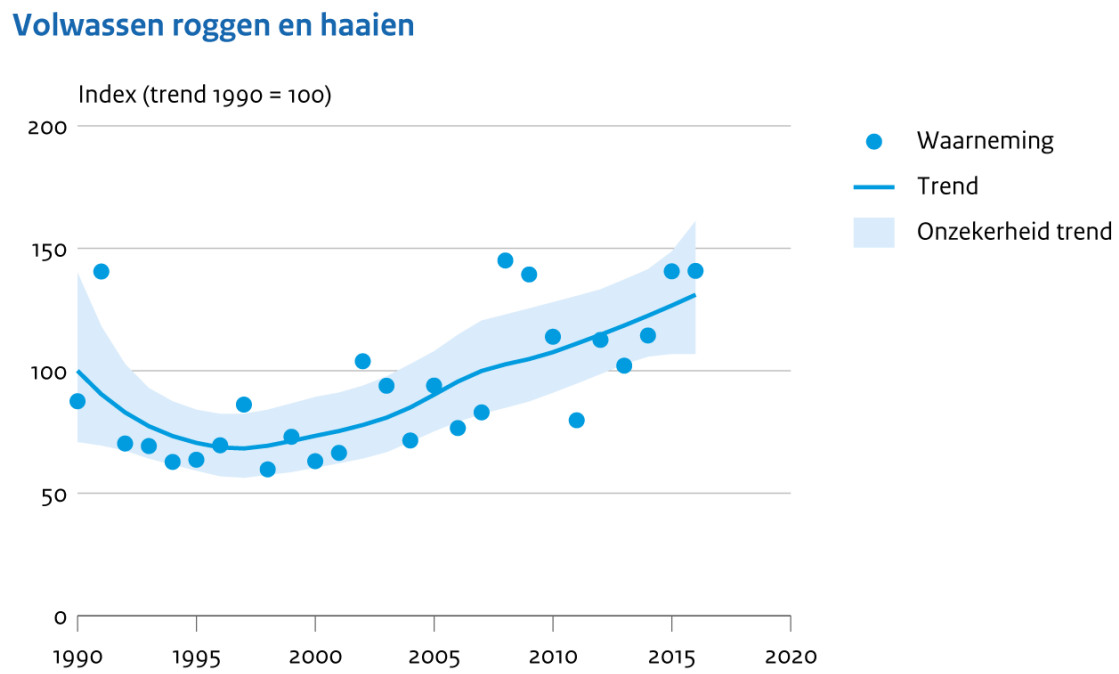

Bron: ICES; WMR

CBS/novi7 www.clo.nl/nl124910

Figuur 20 CLO indicator Roggen en haaien (CBS et al., 2017c).

De vismigratieknelpunten zijn nog niet opgelost (Figuur 21). Binnen de KRM is een doel gesteld om de resterende vismigratieknelpunten in Nederland aan te pakken om de connectiviteit tussen watersystemen te herstellen waarbij wordt aangesloten bij de KRW (Ministerie van I\&W en LNV, 2018). 


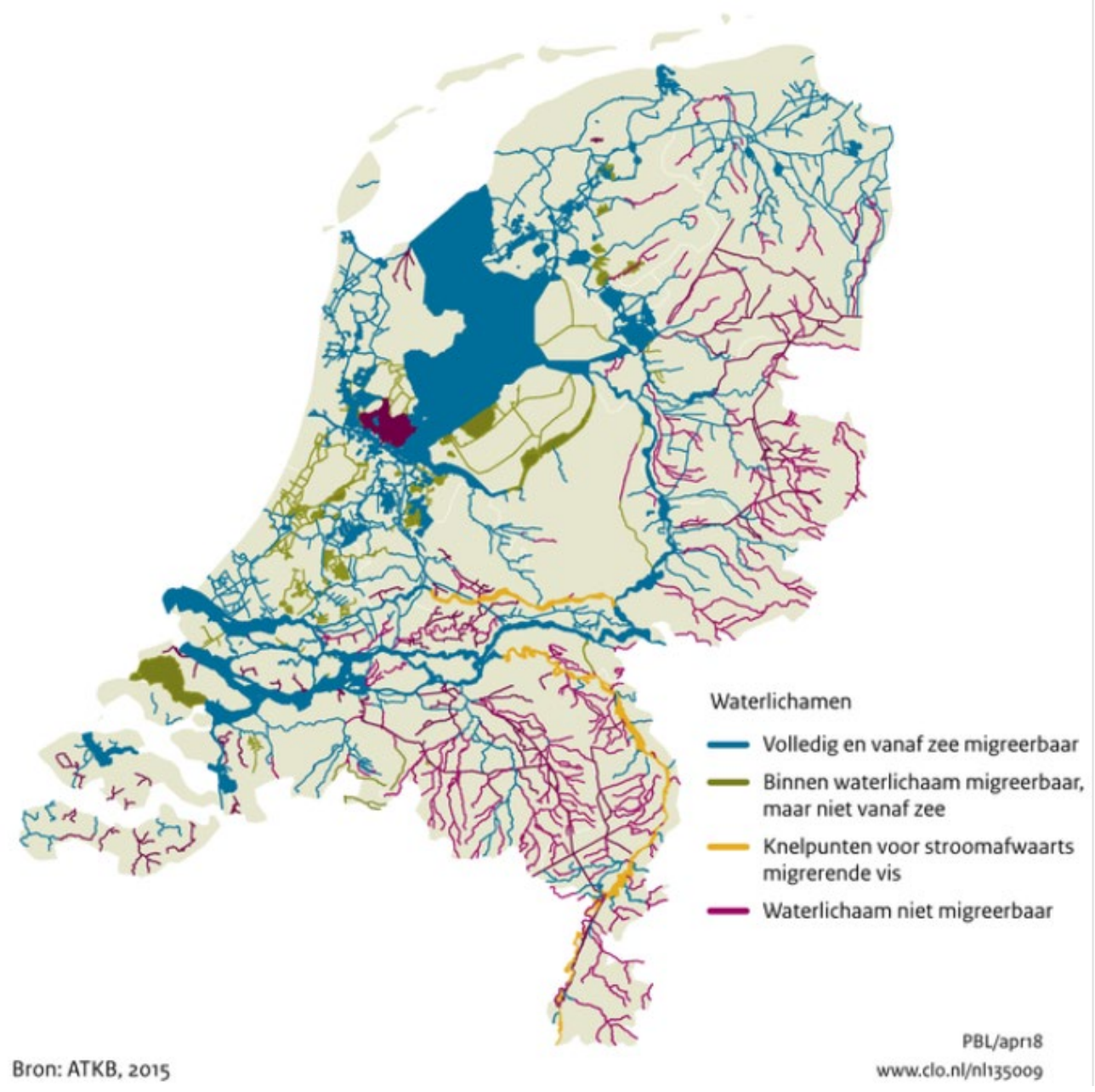

Figuur 21 CLO indicator Migratiemogelijkheden voor trekvissen (CBS et al., 2018).

De toestand van de commerciële visbestanden wordt onder visserij beschreven (paragraaf 4.3.2).

\section{Belangrijke drukfactoren en activiteiten}

De belangrijkste drukfactoren en activiteiten die bijdragen aan het totaal risico voor vissen, die zijn geïdentificeerd aan de hand van de CEA, zijn:

- Toevoer van stoffen door o.a. scheepvaart, havens, activiteiten op land (waterzuivering en landbouw), toerisme en recreatie, olie- en gasactiviteiten;

- Onttrekking van soorten door o.a. visserij;

- Botsingen door o.a. visserij, scheepvaart en recreatievaart met motoren;

- Verandering van habitatstructuur door o.a. visserij, delfstofwinning en baggeren.

Bij de Nederlandse KRM wordt ook uitgegaan van zwerfvuil, de toevoer van stoffen (verontreiniging) en onttrekking van soorten als belangrijke drukfactoren, zie Figuur 22. Daarnaast zijn ook onderwatergeluid en migratie barrières genoemd. De belangrijkste activiteiten vanuit de KRM komen grotendeels overeen met de activiteiten die zijn geïdentificeerd aan de hand van de CEA, 


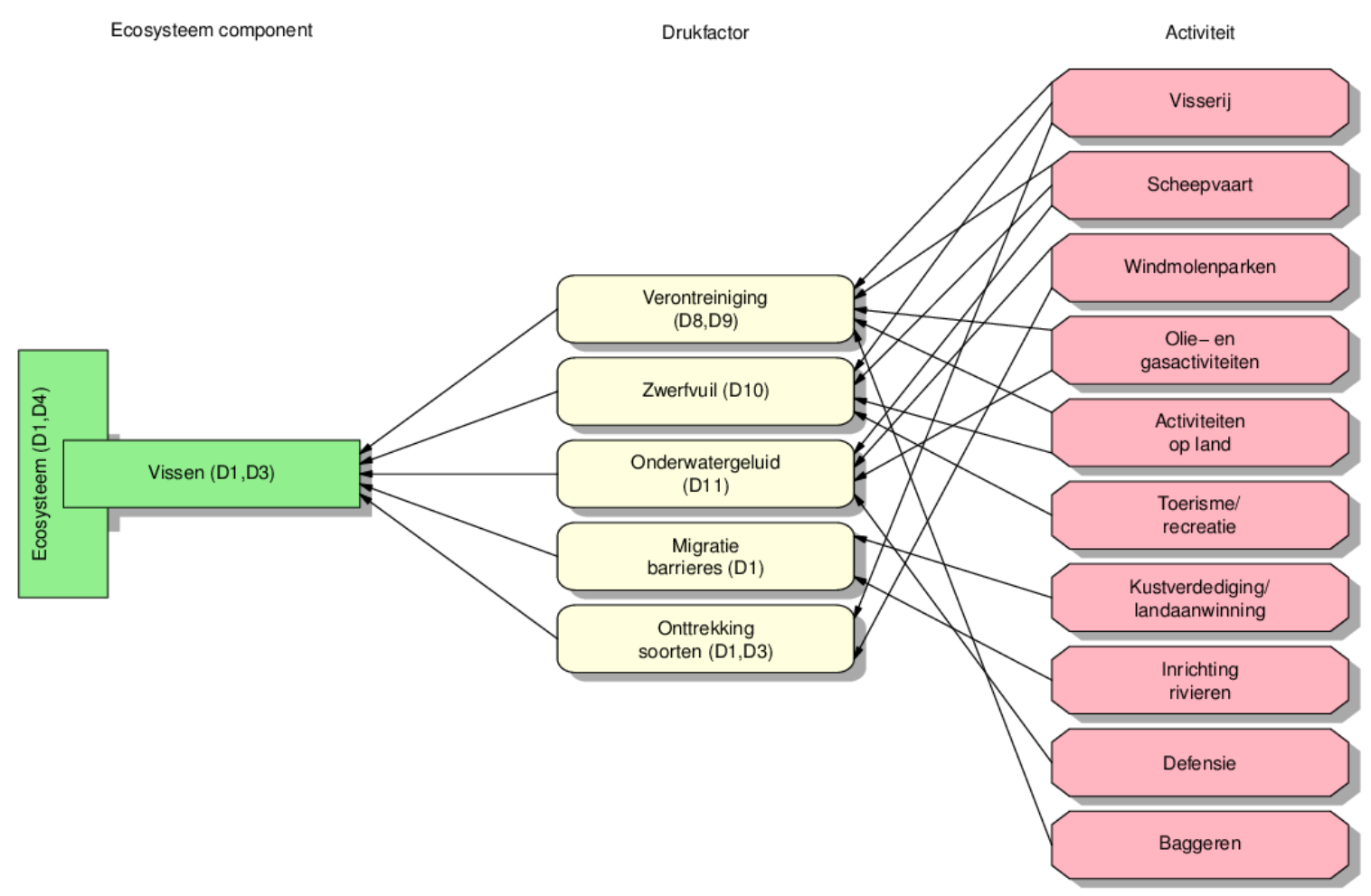

Figuur 22 Vissen als onderdeel van het Noordzee ecosysteem en de drukfactoren en activiteiten die invloed daarop hebben. De relaties zijn zoveel mogelijk gebaseerd op informatie vanuit de Nederlandse KRM (Ministerie van IenM en EZ, 2014; Ministerie van I\&W en LNV, 2018). D1 Biodiversiteit; D2 Niet-inheemse soorten; D3 Commerciële visbestanden; D4 Voedselweb; D5 Eutrofiering; D6 Bodemintegriteit; D7 Hydrografische eigenschappen; D8 Vervuilende stoffen; D9 Vervuilende stoffen in vis; D10 Zwerfvuil; D11 Energietoevoer, o.m. onderwatergeluid.

\section{Beleidsmaatregelen}

De milieudoelen om de voortgang tot GMT voor vissen te begeleiden zijn (Ministerie van I\&W en LNV, 2018):

- D1T5: onderzoek naar haaien en roggen in combinatie met het nemen van mitigerende maatregelen zoals vastgelegd in Actieplan Haaien en roggen:

- communicatie en educatie

○ vermindering ongewenste bijvangsten

○ verhogen overleving.

- D1T6: aanpakken van de resterende vismigratieknelpunten in Nederland om de connectiviteit tussen watersystemen te herstellen (KRW).

- D1T8: onderzoek naar de noodzaak van visserijvrije zones rondom kunstwerken ter bevordering van de migratiemogelijkheden voor trekvissen (KRW).

- D3T1: het beheer van alle commercieel beviste bestanden voldoet aan F $\leq$ Fmsy en een paaibiomassa boven het voorzorgniveau MSY Btrigger.

- D1T3: realiseren van instandhoudingsdoelstellingen voor habitattypen en soorten in de Natura 2000-gebieden op zee (VHR).

- D4T1: ontwikkelen en testen van regionale beoordelingsmethoden die in de toekomst gebruikt kunnen worden voor een beoordeling van de status van voedselwebben (ook relevant voor de andere ecosysteem onderdelen).

Selectie van maatregelen uit het programma van maatregelen (2015), zoals aangegeven door het Ministerie van I\&W en LNV (2018):

- beperken visserij en andere activiteiten in Natura 2000-gebieden;

- implementatie OSPAR-lijst bedreigde soorten;

- vergunningvereisten bij grootschalige ingrepen; 
- gedeeltelijke openstelling Haringvlietsluizen;

- $\quad$ maatregelen m.b.t. D3 (commerciële visbestanden), zie 0

In de Mariene Strategie (Ministerie van I\&W en LNV, 2018) is geconcludeerd dat het bestaand beleid voldoet om de GMT voor de biodiversiteit van de visgemeenschap, inclusief commerciële vissoorten te behalen (Ministerie van I\&W en LNV, 2018).

\subsubsection{Zeebodem}

\section{Huidige toestand en trend}

De GMT voor zeebodem habitats is een verbetering van de omvang, conditie en globale verspreiding van de benthische gemeenschap en specifieke benthische soorten. Dit is uitgewerkt in de volgende criteria (Tabel 10):

- D6C3: Voor de habitats die in het kader van de habitatrichtlijn zijn beschreven, gelden de instandhoudingsdoelen voor deze habitats (NL - HR beoordeling $\mathrm{H} 1110$ en H1170); Verbetering van de kwaliteit van de beoordeelde gebieden en habitats op het Nederlandse deel van de Noordzee (Benthische Indicator Soorten Index).

- D6C5: de diversiteit van benthos vertoont geen afnemende trend in de beoordeelde gebieden (OSPAR- beoordelingswaarde).

Deze criteria maken ook deel uit van de beoordeling van de verstoring van de zeebodem (zie paragraaf 4.3.4). De GMT voor zeebodem habitats is niet gehaald en deels onbekend (Ministerie van I\&W en LNV, 2018).

Onder de descriptor 'voedselweb' (D4) is het doel gesteld dat het effect van menselijke interventies op interacties tussen verschillende trofische niveaus in het voedselweb wordt verminderd. Deze descriptor is nog niet volledig uitgewerkt. Criterium D4C1 vereist dat de diversiteit (soortsamenstelling en de abundantie) van ten minste drie geselecteerde trofische gildes (waaronder ook de benthische gemeenschap) op een niveau is of binnen een normale bandbreedte die duidt op een goede milieutoestand. De te gebruiken trofische gildes en de niveaus en bandbreedtes moeten in de tweede cyclus nog regionaal worden vastgesteld. De Europese Commissie (DG Environment) heeft ICES verzocht om indicatoren te benoemen waarmee de druk en de impact van de bodemberoerende visserij op de zeebodem kunnen worden bepaald en ook de wisselwerking tussen de vangst en de waarde van de aan land gebrachte vis (ICES, 2017). Fysiek verlies van de zeebodem door o.a. infrastructurele activiteiten wordt ook nog verder ontwikkeld.

Tabel 10 Toestandsbeoordeling van zeebodem habitats (gebaseerd op de KRM beoordeling door Ministerie van I\&W en LNV, 2018). De status geeft aan of de goede milieutoestand is gehaald (goed), niet gehaald (niet goed), nog niet bekend is vanwege bijvoorbeeld het ontbreken van vastgestelde grenswaarden/streefwaarden (onbekend). Voor sommige criteria is geen status gerapporteerd (-)

\begin{tabular}{|c|c|c|c|}
\hline Criteria & Goede milieutoestand & Indicator & Status \\
\hline D6C3 & $\begin{array}{l}\text { Voor de habitats die in het kader van de habitatrichtlijn zijn } \\
\text { beschreven, gelden de instandhoudingsdoelen voor deze } \\
\text { habitats. }\end{array}$ & $\begin{array}{l}\mathrm{NL}-\mathrm{HR} \text { beoordeling } \mathrm{H} 1110 \\
\text { en } \mathrm{H} 1170\end{array}$ & $\begin{array}{l}\text { Niet } \\
\text { goed* }\end{array}$ \\
\hline D6C3 & $\begin{array}{l}\text { Verbetering kwaliteit van de beoordeelde gebieden en habitats } \\
\text { op het NL deel van de Noordzee }\end{array}$ & $\begin{array}{l}\text { NL - Benthische Indicator } \\
\text { Soorten Index (BISI) }\end{array}$ & Onbekend \\
\hline D6C5 & $\begin{array}{l}\text { De diversiteit van benthos vertoont geen afnemende trend in } \\
\text { de beoordeelde gebieden (OSPAR) }\end{array}$ & $\begin{array}{l}\text { OSPAR - Conditie van } \\
\text { benthische gemeenschappen } \\
\text { (MMI) }\end{array}$ & Onbekend \\
\hline
\end{tabular}

In 2019 zal voor de EU Habitatrichtlijn de status van de habitattypen over de periode 2013-2018 worden gerapporteerd. Volgens eerdere resultaten uit 2013

(http://cdr.eionet.europa.eu/Converters/nl/eu/art17/envukhtvq/NL_habitats_reports_2013-12-10T1334-58.xml/manage_document) is de verspreiding en het oppervlak van $\mathrm{H} 1110$ (permanent overstroomde zandbanken) en $\mathrm{H} 1170$ (riffen) gunstig. De structuur en functies van beide habitattypen waren echter onvoldoende waardoor de status ongunstig is.

De Nederlandse Benthische Indicator Soorten Index (BISI) is als nationale indicator ontwikkeld om de habitat-kwaliteitstoestand van de zeebodem voor onder andere de KRM en HR te kunnen beoordelen 
(Wijnhoven \& Bos, 2017; Ministerie van I\&W en LNV, 2018). In Tabel 11 staan de resultaten voor de gebieden met bijzondere ecologische waarden weergegeven. Resultaten zijn ook beschikbaar per EUNIS 3 type en per HR habitattype. Uit de nationale beoordeling van de benthische gemeenschappen blijkt dat vooral de langlevende, gevoelige soorten duidelijk minder voorkomen dan is gewenst en ook dat de biodiversiteit nog onvoldoende is (Ministerie van I\&W en LNV, 2018). De status voor 2018 is echter nog niet bekend doordat een verbetering ten opzichte van de T0 (situatie in 2015) moet worden vastgesteld. Voor deze trend beoordeling zijn nu nog geen gegevens beschikbaar (het eerstvolgende jaar met benthos monitoring is 2018). Momenteel is het dus onbekend of aan de GMT voor dit criterium wordt voldaan. Op basis van indicatieve trends lijkt het er echter erop dat in 2018 nog niet voldaan wordt aan GMT (Ministerie van I\&W en LNV, 2018).

Tabel 11 Samenvatting huidige kwaliteitstoestand (2015) en ontwikkeling ten opzichte van de recent historische ontwikkeling (indicatief 1995-2014) op basis van de BISI voor de te evalueren gebieden van de Nederlandse Noordzee. Alle gepresenteerde BISI-scores (kwaliteitstoestand relatief ten opzichte van de interne referentie die gelijk is aan ' 1 ') weergegeven \pm standaarddeviatie, zijn significant afwijkend van de interne referentie met $p<0,05$ (Ecoauthor, 2018)

\begin{tabular}{|c|c|c|c|}
\hline $\begin{array}{l}\text { Te beoordelen } \\
\text { Gebieden }\end{array}$ & $\begin{array}{l}\text { Recent historische } \\
\text { ontwikkeling } \\
\text { kwaliteitstoestand (trend) }\end{array}$ & $\begin{array}{l}\text { Huidige } \\
\text { kwaliteitstoe- } \\
\text { stand (BISI- } \\
\text { score 2015) }\end{array}$ & $\begin{array}{l}\text { Toestand } 2015 \text { ten opzichte } \\
\text { van trend }\end{array}$ \\
\hline \multicolumn{4}{|c|}{ Gebieden met bijzondere ecologische waarden (ASEVs): } \\
\hline Centrale Oestergronden & Toenemend (echter afvlakkend) & $0,370 \pm 0,433$ & Verslechtering \\
\hline Friese Front & $\begin{array}{l}\text { Veranderend van toenemend } \\
\text { naar afnemend }\end{array}$ & $0,410 \pm 0,479$ & Verslechtering \\
\hline Doggersbank & Afnemend & $0,564 \pm 0,460$ & Mogelijk lichte verbetering \\
\hline Voordelta & Fluctuerend op laag niveau & $0,324 \pm 0,494$ & $\begin{array}{l}\text { Vergelijkbaar tot mogelijk lichte } \\
\text { verbetering }\end{array}$ \\
\hline Noordzeekustzone & Fluctuerend op laag niveau & $0,307 \pm 0,429$ & Mogelijk lichte verbetering \\
\hline Vlakte van de Raan & Constant laag niveau & $0,350 \pm 0,460$ & Vergelijkbaar \\
\hline Klaverbank & $\begin{array}{l}\text { Onduidelijk door gebrek aan } \\
\text { data }\end{array}$ & $0,475 \pm 0,654$ & $\begin{array}{l}\text { Vergelijkbaar tot mogelijk lichte } \\
\text { verbetering }\end{array}$ \\
\hline Bruine Bank & Constant laag niveau & $0,274 \pm 0,308$ & Vergelijkbaar \\
\hline
\end{tabular}

De OSPAR indicator laat zien dat in de ondiepe kustgebieden van Nederland, maar ook van België en Duitsland, de benthische gemeenschappen een relatief lage kwaliteit hebben ten opzichte van de diepere offshore gebieden (Figuur 23). Dit is deels te relateren aan de hogere visserijintensiteit in de kustgebieden (OSPAR, 2017). Aangezien een beoordelingswaarde nog ontbreekt kunnen er geen uitspraken worden gedaan of de benthische gemeenschappen van voldoende kwaliteit zijn voor een GMT. 


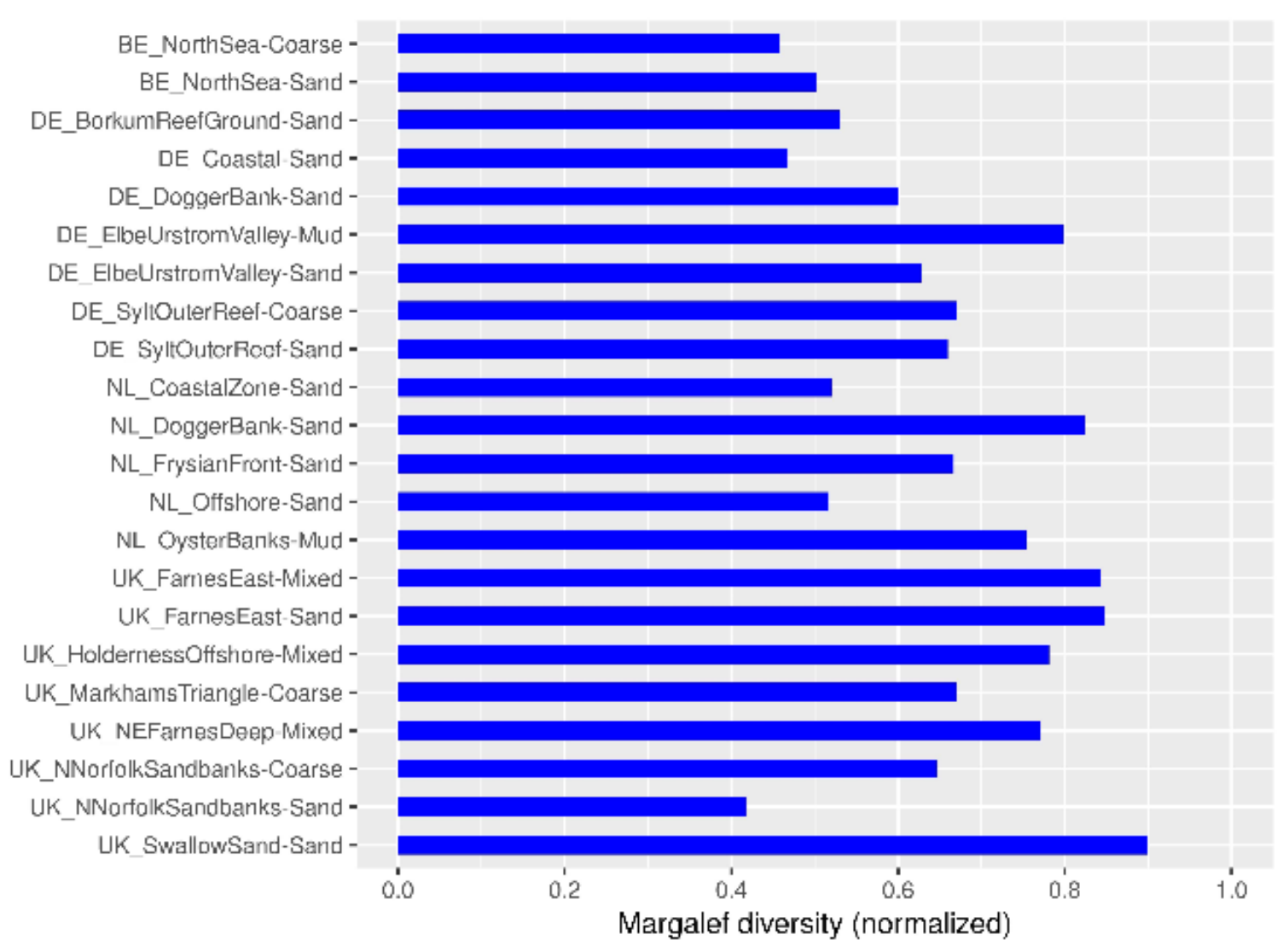

Figuur 23 OSPAR indicator Conditie van benthische gemeenschappen (MMI); beoordelingsresultaten voor de Zuidelijke Noordzee beoordelingsgebieden (habitat typen) op basis van de Margalef diversity scores (range 0-1) gemiddeld over de periode 2010-2015. Een hogere score geeft een betere kwaliteit aan (OSPAR, 2017).

\section{Belangrijke drukfactoren en activiteiten}

De belangrijkste drukfactoren en activiteiten die bijdragen aan het totaal risico voor de zeebodem, die zijn geïdentificeerd aan de hand van de CEA, zijn:

- Onttrekking van soorten door o.a. visserij, toerisme en recreatie en delfstoffenwinning;

- Toevoer van stoffen door o.a. scheepvaart, activiteiten op land (industrie en waterzuivering), havens, olie- en gasactiviteiten;

- Verandering aan habitat structuur/morfologie (o.a. bodemberoerende visserij, zandsuppletie, delfstoffenwinning);

- Zwerfvuil door o.a. visserij, toerisme en recreatie.

Bij de Nederlandse KRM wordt ook uitgegaan van zwerfvuil, de toevoer van stoffen (verontreiniging) en onttrekking van soorten als belangrijke drukfactoren, zie Figuur 24. Veranderingen aan de structuur en morfologie van het habitat zijn dat ook, maar worden in het kader van de KRM beoordeeld onder de descriptoren D6: zeebodemintegriteit (fysiek verlies en fysieke verstoring) en D7: Hydrografische eigenschappen. 


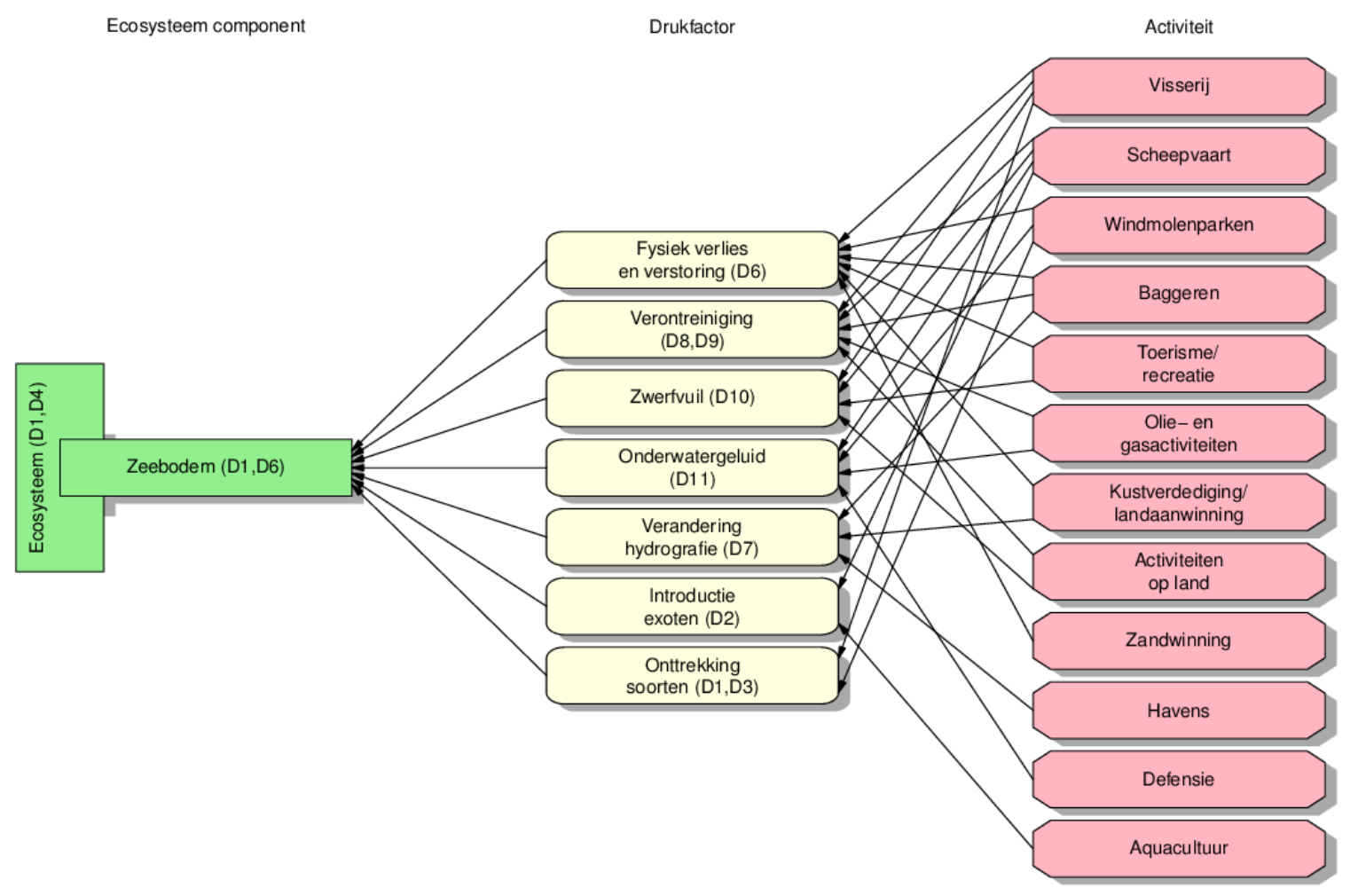

Figuur 24 Zeebodem als onderdeel van het Noordzee ecosysteem en de belangrijkste drukfactoren en activiteiten die invloed daarop hebben. De relaties zijn zoveel mogelijk gebaseerd op informatie vanuit de Nederlandse KRM (Ministerie van IenM en EZ, 2014; Ministerie van I\&W en LNV, 2018). D1 Biodiversiteit; D2 Niet-inheemse soorten; D3 Commerciële visbestanden; D4 Voedselweb; D5 Eutrofiering; D6 Bodemintegriteit; D7 Hydrografische eigenschappen; D8 Vervuilende stoffen; D9 Vervuilende stoffen in vis; D10 Zwerfvuil; D11 Energietoevoer, o.m. onderwatergeluid.

\section{Milieudoelen en beleidsmaatregelen}

De milieudoelen om de voortgang tot GMT voor benthische habitats te begeleiden zijn (Ministerie van I\&W en LNV, 2018):

- D6T1: 10-15 procent van het oppervlak van het Nederlandse deel van de Noordzee wordt niet noemenswaardig beroerd door menselijke activiteiten.

- D6T2: verbetering kwaliteit van de beoordeelde gebieden en habitats.

- D6T4: verder ontwikkelen en testen van regionale beoordelingsmethoden (OSPAR en ICES) die in de toekomst gebruikt kunnen worden voor een beoordeling van benthische en pelagische habitats.

- D6T5: terugkeer en herstel van biogene riffen, waaronder platte oesterbanken

- D1T3: realiseren instandhoudingsdoelstellingen voor habitattypen en soorten in de Natura 2000-gebieden op zee (VHR).

- D4T1: ontwikkelen en testen van regionale beoordelingsmethoden die in de toekomst gebruikt kunnen worden voor een beoordeling van de status van voedselwebben (ook relevant voor de andere ecosysteem onderdelen).

Selectie van maatregelen uit het programma van maatregelen (2015), zoals aangegeven door het Ministerie van I\&W en LNV (2018):

- Bodembescherming in de Kustzone en op Vlakte van de Raan, Doggersbank, Klaverbank, Friese Front en Centrale Oestergronden;

- voorwaarden aan vergunningverlening zandwinning en -suppletie;

- stimulering alternatieve vistuigen. 
In de Mariene Strategie (Ministerie van I\&W en LNV, 2018) is geconcludeerd dat het aanvullend beleid wat in 2012 is ingezet om de GMT voor benthische habitats te behalen moet worden voortgezet (Ministerie van I\&W en LNV, 2018). Dit betreft de aanvullende bodembescherming in het Friese Front en Centrale Oestergronden. In de loop van 2017 is een voorstel gedaan om op drie gebieden met een totale omvang van $2000 \mathrm{~km}^{2}$ geen bodemberoerende visserij toe te staan (Figuur 25). De Commissie zal de bodembeschermingsmaatregel vervolgens in het Europese Gemeenschappelijk Visserij Beleid verankeren. Verder is er een kennisopgave vastgesteld met betrekking tot beoordelingsmethode, cumulatie en hard substraat (Ministerie van I\&W en LNV, 2018).

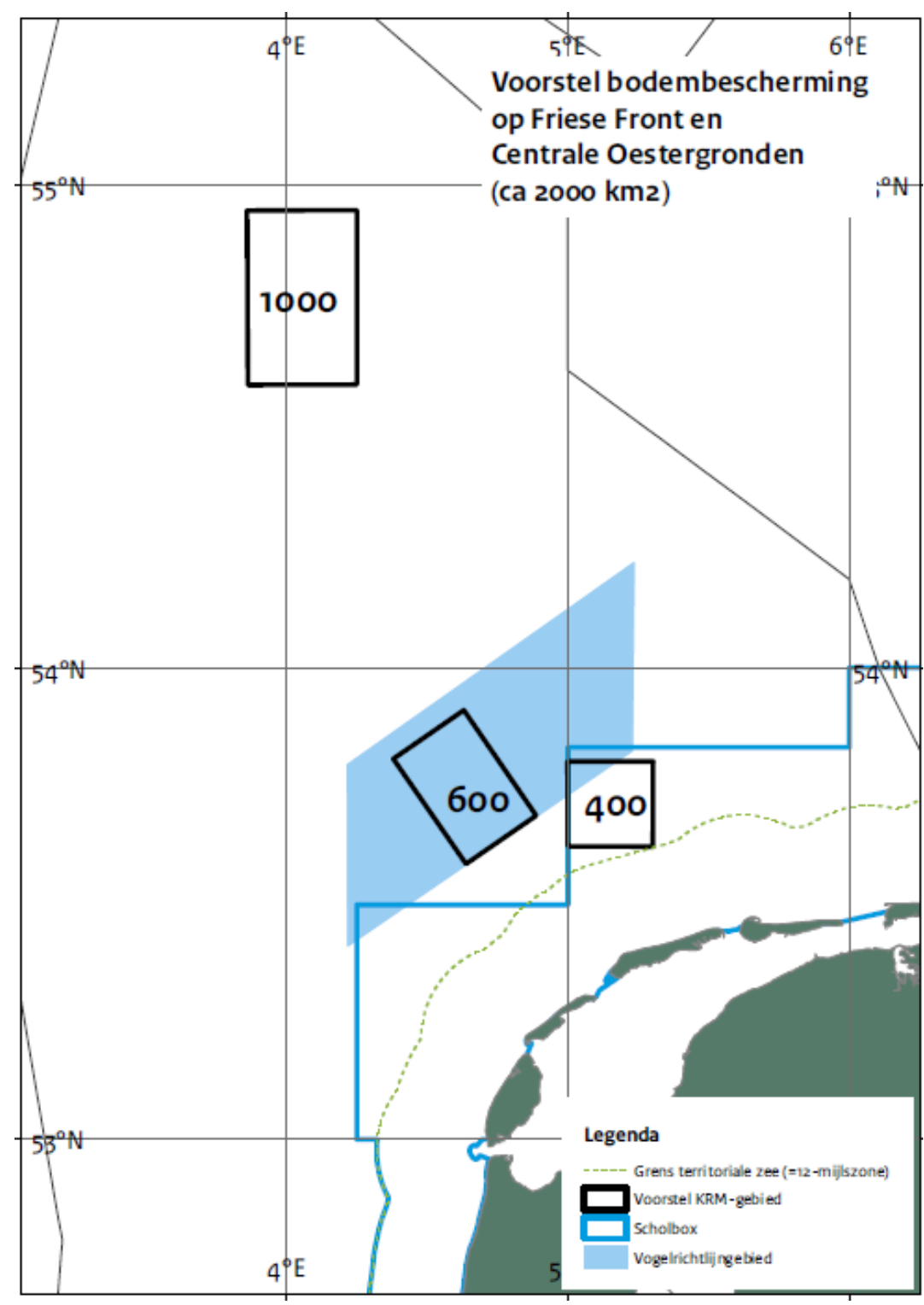

Figuur 25 Voorstel bodembescherming op het Friese Front en de Centrale Oestergronden (https://www.noordzeeloket.nl/beleid/europese/nationaal-niveau/bodembescherming/).

\subsubsection{Waterkolom}

\section{Huidige toestand en trend}

Voor pelagische habitats is de GMT bereikt wanneer de ruimtelijke en temporele variatie in de planktongemeenschap binnen een bandbreedte blijft die duidt op een goede milieutoestand. Dit is vastgelegd in criterium D1C6 (Tabel 12, Ministerie van I\&W en LNV, 2018). De te gebruiken bandbreedtes moeten in de tweede cyclus van de KRM regionaal nog worden vastgesteld, waardoor de huidige toestand momenteel nog onbekend is. De indicatoren voor de biodiversiteit van pelagische habitats worden binnen OSPAR verder ontwikkeld. Er zijn wel veranderingen waarneembaar in zowel de structuur van de planktongemeenschappen (Figuur 26) als de biomassa en abundantie (Figuur 27). De veranderingen die zichtbaar zijn in de planktongemeenschappen doet vermoeden dat er 
veranderingen optreden in de interactie tussen benthische en pelagische componenten van het ecosysteem en in de samenstelling van het voedselweb of van energiestromen (OSPAR, 2017). Het is momenteel niet mogelijk veranderingen in planktongemeenschappen aan specifieke menselijke bedreigingen te koppelen (OSPAR, 2017). Planktongemeenschappen maken ook onderdeel uit van de beoordeling van het voedselweb: soortensamenstelling en relatieve dichtheid van trofische gilden (D4C1) en evenwicht tussen de trofische gilden (D4C2). Deze criteria met bijbehorende indicatoren zijn nog niet volledig ontwikkeld (zie ook paragraaf 5.2 onder het kopje 'D4 voedselweb').

De algenbiomassa wordt ook beoordeeld onder de drukfactor eutrofiëring (D5C2, zie paragraaf 4.3.3).

Tabel 12 Toestandsbeoordeling waterkolom (gebaseerd op de KRM beoordeling door Ministerie van I\&W en LNV, 2018). De status geeft aan of de goede milieutoestand is gehaald (goed), niet gehaald (niet goed), nog niet bekend is vanwege bijvoorbeeld het ontbreken van vastgestelde grenswaarden/streefwaarden (onbekend).

\begin{tabular}{|l|l|l|l|}
\hline Criteria & Goede milieutoestand & Indicator \\
\hline D1C6 & $\begin{array}{l}\text { Voor pelagische habitats is de goede milieutoestand bereikt } \\
\text { wanneer de ruimtelijke en temporele variatie in de plankton } \\
\text { gemeenschap binnen de een langjarige bandbreedte blijt die } \\
\text { duidt op een goede milieutoestand. De te gebruiken } \\
\text { bandbreedtes moeten in de tweede cyclus nog regionaal } \\
\text { worden vastgesteld }\end{array}$ & $\begin{array}{l}\text { OSPAR PH1/FW5 - } \\
\text { Veranderingen in } \\
\text { fytoplankton- en } \\
\text { zoöplanktongemeenschappen. }\end{array}$ & $\begin{array}{l}\text { OSPAR PH2 - Veranderingen } \\
\text { in biomassa van fytoplankton } \\
\text { en abundantie van } \\
\text { zoöplankton }\end{array}$ \\
\hline
\end{tabular}

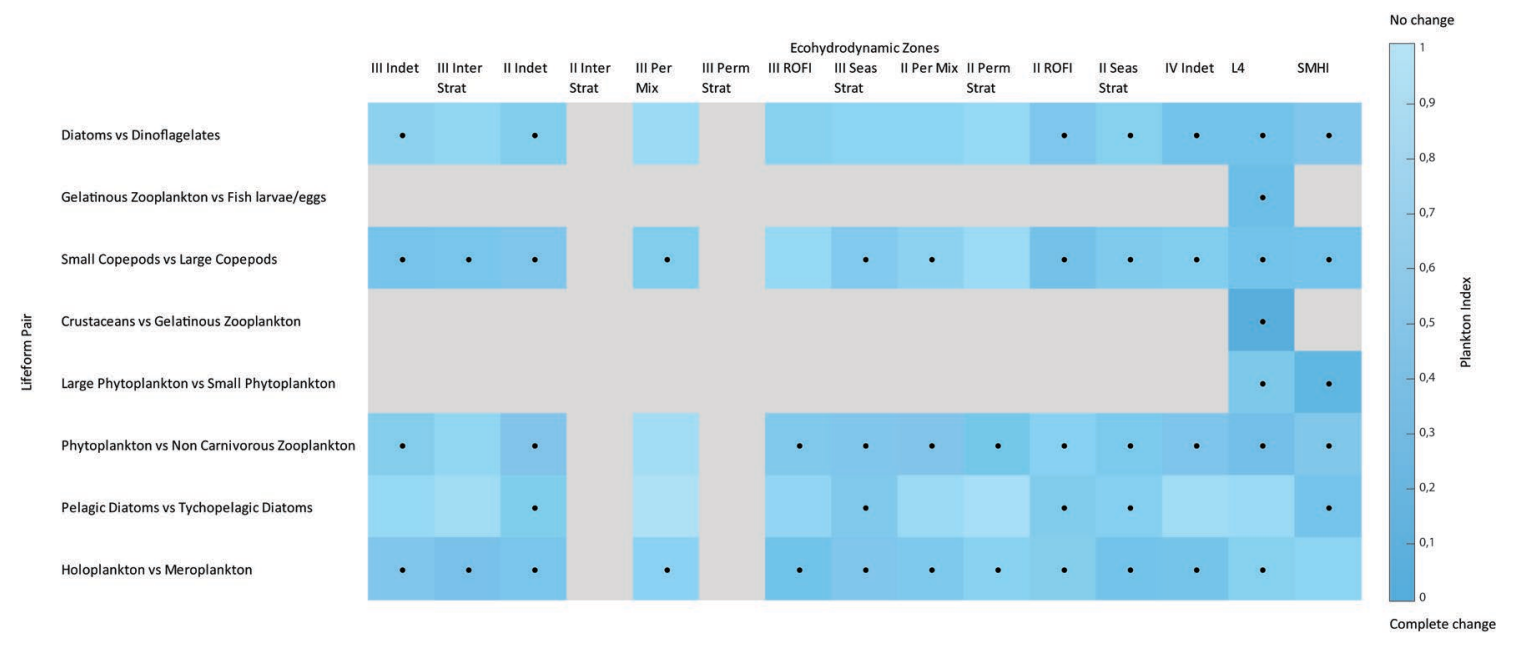

Figuur 26 OSPAR indicator Veranderingen in de planktonindex per levensvormpaar van 2004 tot 2008 en van 2009 tot 2014 (OSPAR, 2017). Hoe donkerder de kleur blauw, des te groter de verandering. Als de gegevens onvoldoende of te fragmentarisch waren om de planktonindex te kunnen vaststellen, zijn de desbetreffende velden grijs gearceerd. Stippen duiden op een significante verandering $(p<0,01)$ sinds het tijdvak 2004-2008. Het feit dat er veranderingen in de planktonindex optreden, duidt niet automatisch op een achteruitgang in milieuomstandigheden. Het wijst wel op veranderingen ten opzichte van de uitgangssituatie. 
PH2 PHYTO North Sea intermittently stratified waters

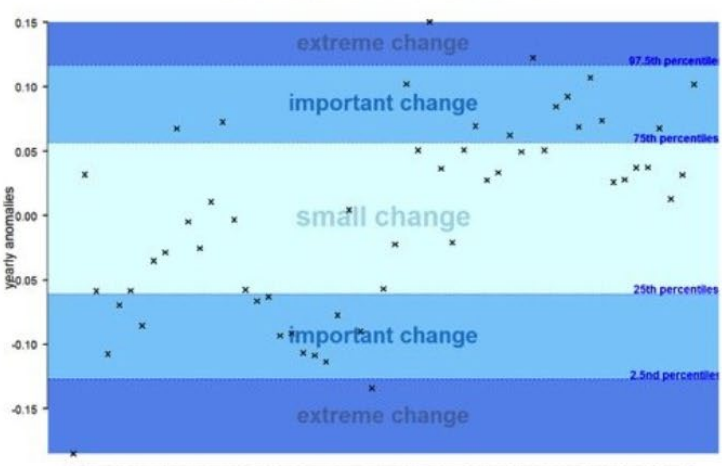

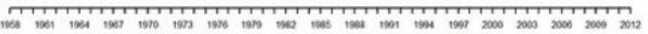

PH2 Zoo North Sea intermittenty stratfied waters

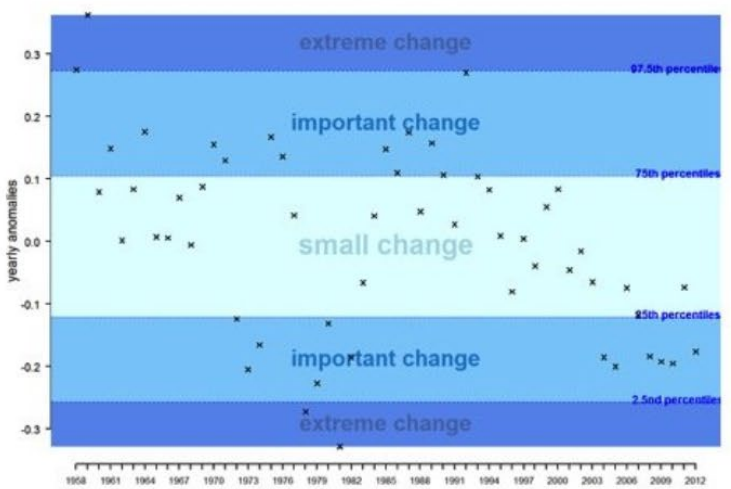

Figuur 27 OSPAR indicator Veranderingen in biomassa van fytoplankton (links) en abundantie van zoöplankton (rechts) (OSPAR, 2017).

\section{Belangrijke drukfactoren en activiteiten}

De belangrijkste drukfactoren en activiteiten die bijdragen aan het totaal risico voor de waterkolom, die zijn geïdentificeerd aan de hand van de CEA, zijn:

- Onttrekking van soorten door o.a. visserij en delfstoffenwinning;

- Introductie van microbiële pathogenen door o.a. visserij, toerisme en recreatie.

- Zwerfvuil door o.a. visserij, toerisme en recreatie;

- Toevoer van stoffen door o.a. scheepvaart, activiteiten op land (industrie en landbouw), olieen gasactiviteiten, havens.

Bij de Nederlandse KRM wordt naast zwerfvuil uitgegaan van andere belangrijke drukfactoren dan hierboven genoemd, zie Figuur 28. De belangrijkste activiteiten vanuit de KRM komen grotendeels wel overeen met de activiteiten die zijn geïdentificeerd aan de hand van de CEA, 


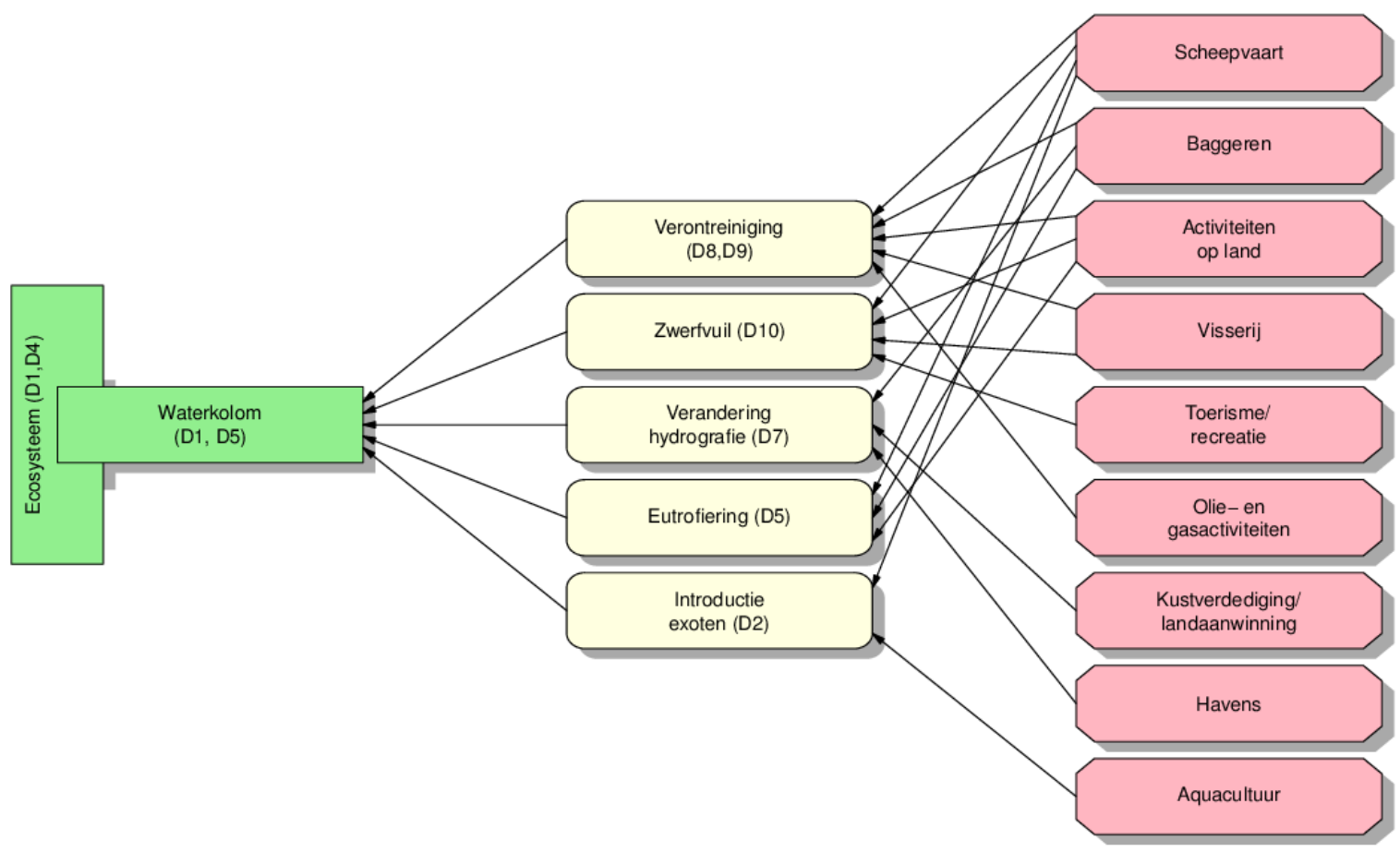

Figuur 28 Waterkolom als onderdeel van het Noordzee ecosysteem en de belangrijkste drukfactoren en activiteiten die invloed daarop hebben. De relaties zijn zoveel mogelijk gebaseerd op informatie vanuit de Nederlandse KRM (Ministerie van IenM en EZ, 2014; Ministerie van I\&W en LNV, 2018). D1 Biodiversiteit; D2 Niet-inheemse soorten; D3 Commerciële visbestanden; D4 Voedse/web; D5 Eutrofiering; D6 Bodemintegriteit; D7 Hydrografische eigenschappen; D8 Vervuilende stoffen; 99 Vervuilende stoffen in vis; D10 Zwerfvuil; D11 Energietoevoer, o.m. onderwatergeluid.

\section{Milieudoelen en beleidsmaatregelen}

De milieudoelen om de voortgang tot GMT voor pelagische habitats te begeleiden zijn (Ministerie van I\&W en LNV, 2018):

- D6T4: verder ontwikkelen en testen van regionale beoordelingsmethoden die in de toekomst kunnen worden gebruikt voor een beoordeling van benthische en pelagische habitats.

- D4T1: ontwikkelen en testen van regionale beoordelingsmethoden voor de plankton gemeenschap die in de toekomst gebruikt kunnen worden voor een beoordeling van de status van voedselwebben (ook relevant voor de andere ecosysteem onderdelen).

De selectie van maatregelen uit het programma van maatregelen (2015), zoals aangegeven door het Ministerie van I\&W en LNV (2018), staat beschreven onder 4.3.3 (eutrofiëring).

In de Mariene Strategie (Ministerie van I\&W en LNV, 2018) is geconcludeerd dat het onbekend is of het bestaand beleid voldoet om de GMT voor de biodiversiteit van pelagische habitats te behalen. Wel ligt er een kennisopgave met betrekking tot het ontwikkelen van een beoordelingsmethode (Ministerie van I\&W en LNV, 2018). 


\subsection{Menselijke activiteiten en hun drukfactoren}

\subsubsection{Niet-inheemse soorten}

\section{Huidige toestand en trend}

Aangezien het niet mogelijk is om eenmaal gevestigde niet-inheemse soorten kosteneffectief en zonder aanzienlijke schade aan het ecosysteem te bestrijden wordt de aanwezigheid van reeds gevestigde niet-inheemse soorten als onomkeerbaar beschouwd en is het bereiken van de GMT gelijk aan het streven om het huidige ecosysteem niet verder te laten veranderen als gevolg van nieuwe introducties (Ministerie van I\&W en LNV, 2018). De KRM doelstelling voor de introductie of verspreiding van niet-inheemse soorten lijkt gehaald (Tabel 13).

Tabel 13 Toestandsbeoordeling KRM descriptor 2, niet-inheemse soorten (gebaseerd op Ministerie van I\&W en LNV, 2018). De status geeft aan of de goede milieutoestand is gehaald (goed), niet gehaald (niet goed), nog niet bekend is vanwege bijvoorbeeld het ontbreken van vastgestelde grenswaarden/streefwaarden (onbekend).

\begin{tabular}{|l|l|l|}
\hline Criteria & Goede milieutoestand & Indicator \\
\hline D2C1 & $\begin{array}{l}\text { Dalende trend in het aantal introducties van niet-inheemse } \\
\text { soorten per beleidsperiode (6 jaar). }\end{array}$ & $\begin{array}{l}\text { OSPAR - Trends in nieuwe } \\
\text { gegevens over niet-inheemse } \\
\text { soorten (NIS) die zijn } \\
\text { geïntroduceerd door } \\
\text { menselijke activiteiten. }\end{array}$ \\
\cline { 3 - 4 } & $\begin{array}{l}\text { D2: Periodiek overzicht van } \\
\text { vastgestelde niet-inheemse } \\
\text { soorten van het Nederlandse } \\
\text { deel van de Noordzee en hun } \\
\text { transportvectoren; op basis } \\
\text { van de best beschikbare } \\
\text { kennis. }\end{array}$ \\
\hline
\end{tabular}

De toestand is beoordeeld op basis van een beschrijving voor het Nederlands deel van de Noordzee (Gittenberger et al. 2017a en 2017b). Gittenberger et al. (2017a en 2017b) rapporteert de nietinheemse mariene soorten in Nederland, waaronder o.a. wieren, geleedpotigen, wormen, weekdieren, nematoden en vissen. De afgelopen 6 jaar (2012-2018) is er slechts 1 nieuwe introductie waargenomen in de Nederlandse Noordzee terwijl dit aantal in de perioden daarvoor vele malen hoger was (Figuur 29). De toestand op basis van de indicator voor de internationale Noordzee (OSPAR indicator) is onduidelijk. Voor de internationale Noordzee is het aantal niet-inheemse soorten toegenomen (Figuur 30). Het gemiddeld aantal nieuwe introducties is wel afgenomen maar door de grote jaarlijkse variatie is er geen trend vast te stellen: In de periode 2003-2008 was het gemiddeld aantal nieuwe introducties 10.17 en in de periode 2009-2014 was dat 7.67, waarvan het verschil niet statistisch significant is (OSPAR, 2017). 


\section{Uitheemse soorten waargenomen in de Nederlandse Noordzee}

9

8

7

6

5

4

3

2

1

o

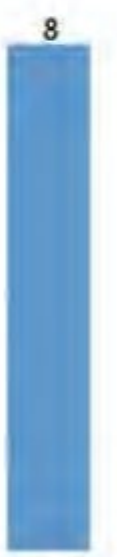

2000-2005

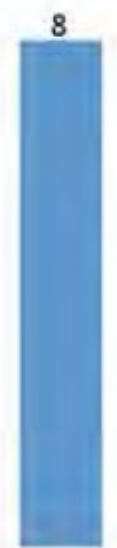

2006-2011

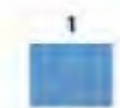

2012-2018

Figuur 29 Het aantal soorten dat voor het eerst in Nederland is waargenomen, sinds 1994, binnen perioden van zes jaar. Betreft alleen niet-inheemse soorten die zijn waargenomen in de Nederlandse Noordzee en hun oorspronkelijke verspreidingsgebied buiten Noordwest-Europa hebben (Gittenberger et al. 2017a).

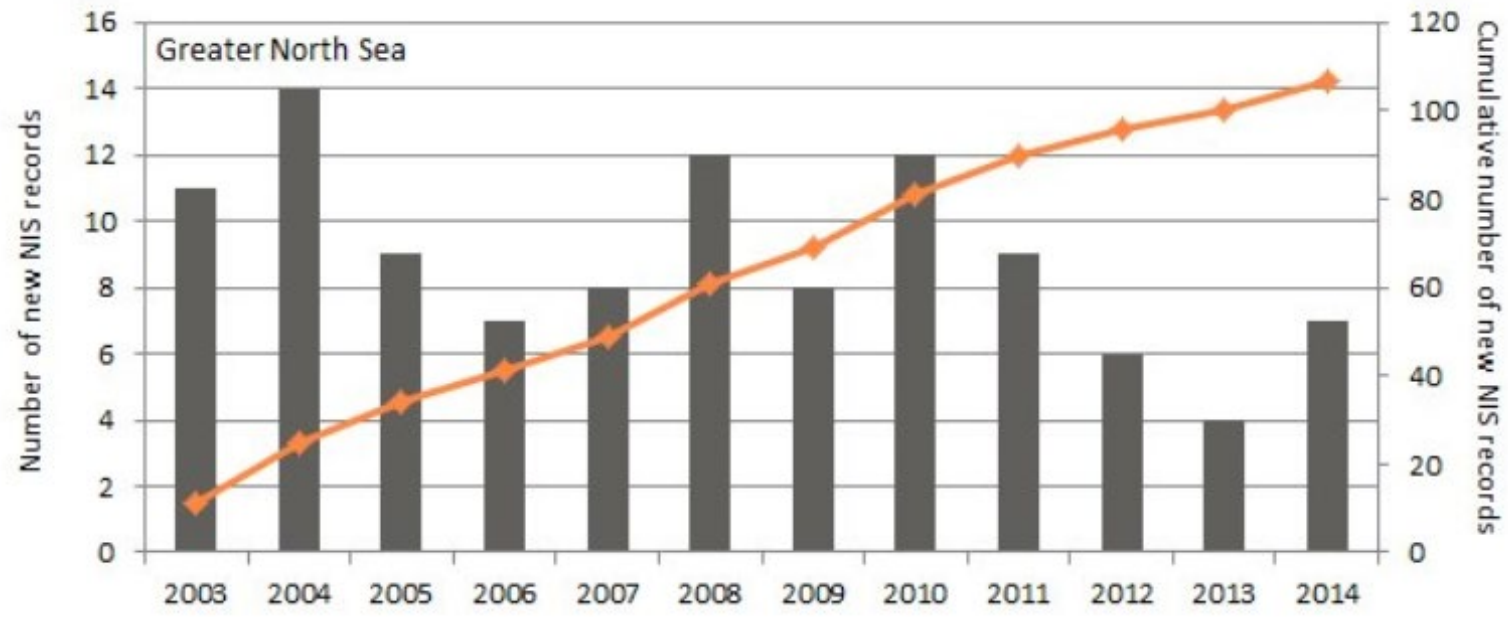

Figuur 30 Het aantal nieuwe introducties van niet-inheemse soorten in de internationale Noordzee (OSPAR, 2017). De lijn laat het gecumuleerde aantal zien.

\section{Belangrijke activiteiten en drukfactoren}

De belangrijkste activiteiten die bijdragen aan het totaal risico op de introductie van niet-inheemse soorten (in volgorde van hoog tot laag risico) die zijn geïdentificeerd aan de hand van de CEA, zijn: scheepvaart; toerisme en recreatie; militaire operaties en pelagische visserij.

De Mariene Strategie (Ministerie van I\&W en LNV, 2018) gaat uit van slechts twee belangrijke activiteiten waarbij naast scheepvaart de import van mosselzaad voor schelpdierkweek (beschouwd als aquacultuur) is genoemd. De analyse van Gittenberger et al. (2017a en 2017b), waar de KRM beoordeling grotendeels op is gebaseerd, geeft namelijk aan dat de drie belangrijkste primaire vectoren waarmee uitheemse soorten die gevestigd zijn in de Noordzee, oorspronkelijk in Noordwest Europese wateren werden geïntroduceerd, ballastwater, scheepshuidaangroei en schelpdiertransporten zijn. De belangrijkste secundaire verspreidingsvector waarmee deze soorten zich na hun introductie in Noordwest Europa verder hebben verspreid betreft natuurlijke verspreiding (Gittenberger et al., 2017a en 2017b).

$\mathrm{Er}$ is logischerwijze maar één drukfactor die bijdraagt aan het risico voor deze descriptor: de introductie van niet-inheemse soorten. 


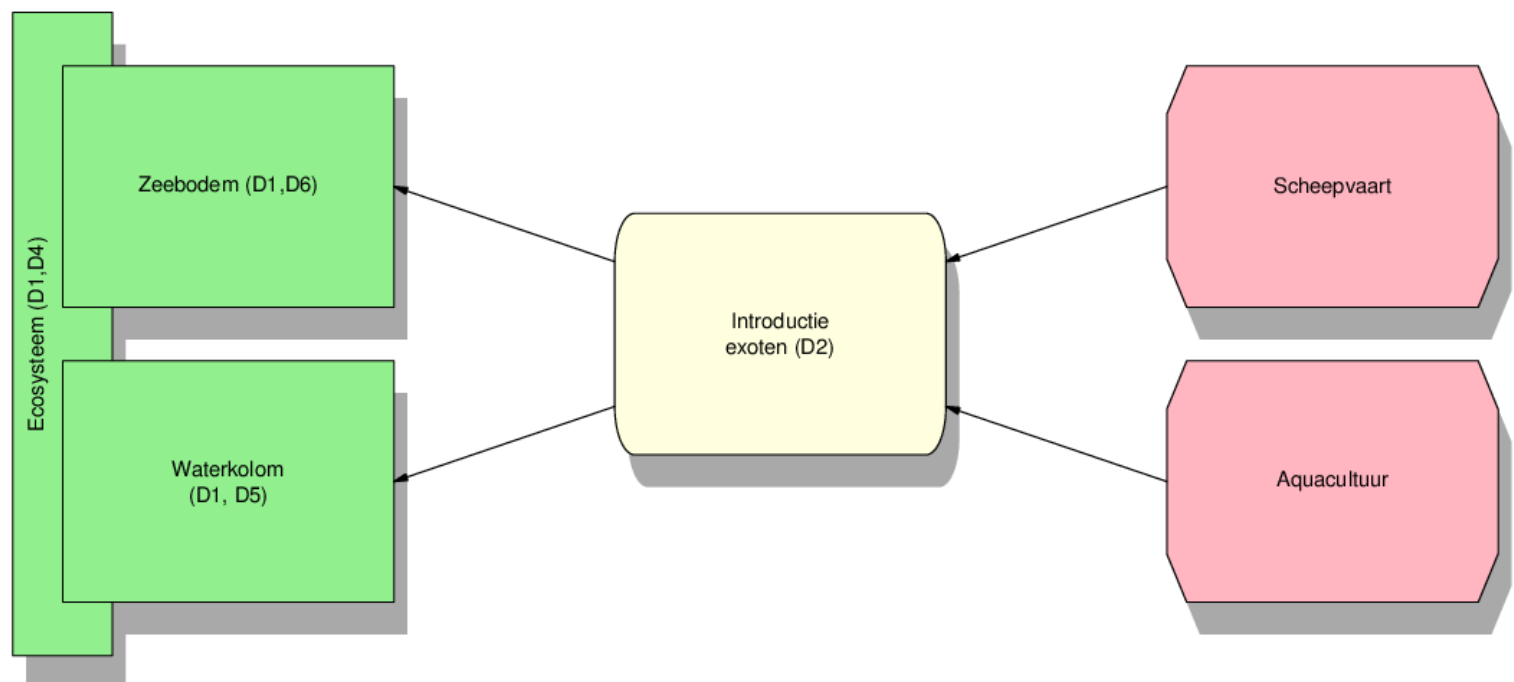

Figuur 31 De drukfactor 'introductie van niet-inheemse soorten', de activiteiten die daar invloed op hebben en de gerelateerde onderdelen van het Noordzee ecosysteem. De relaties zijn zoveel mogelijk gebaseerd op informatie vanuit de Nederlandse KRM (Ministerie van IenM en EZ, 2014; Ministerie van I\&W en LNV, 2018). D1 Biodiversiteit; D2 Niet-inheemse soorten; D3 Commerciële visbestanden; D4 Voedselweb; D5 Eutrofiering; D6 Bodemintegriteit; D7 Hydrografische eigenschappen; D8 Vervuilende stoffen; D9 Vervuilende stoffen in vis; D10 Zwerfvuil; D11 Energietoevoer, o.m. onderwatergeluid.

\section{Milieudoelen en beleidsmaatregelen}

De milieudoelen om de voortgang tot GMT voor niet-inheemse soorten te begeleiden zijn (Ministerie van I\&W en LNV, 2018):

- D2T1: minimaliseren van het risico van nieuwe introducties van niet-inheemse soorten via schelpdiertransporten, ballastwater en scheepshuidaangroei.

De selectie van maatregelen uit het programma van maatregelen (2015), zoals aangegeven door het Ministerie van I\&W en LNV (2018):

- verdere implementatie van het Internationaal verdrag voor de controle en het beheer van ballastwater en sediment van schepen;

- $\quad$ streven naar internationale afspraken over antifouling;

- voorwaarden aan vergunningverlening schelpdiertransport naar Natura 2000-gebieden.

In de Mariene Strategie (Ministerie van I\&W en LNV, 2018) is geconcludeerd dat het risico op de introductie van niet-inheemse soorten met het huidige beleid in 2020 naar verwachting voldoende is afgenomen en dat het bestaand beleid dus voldoet om de GMT voor niet-inheemse soorten te behalen. Wel is genoemd dat het inbrengen van gebiedsvreemd hard substraat in de Noordzee (voor bijvoorbeeld erosiebeschermende bestorting van windparken) een aandachtspunt is, met als risico de primaire of secundaire introductie van niet-inheemse soorten in de Noordzee. Daarom is er een kennisopgave met betrekking tot de toename van hard substraat (Ministerie van I\&W en LNV, 2018).

De belangrijkste routes waardoor niet-inheemse soorten zijn geïntroduceerd zijn via ballastwater, aangroei op scheepshuid en transport van schelpdieren (Ministerie van I\&W en LNV, 2018). De afgelopen periode zijn diverse maatregelen genomen, zoals de implementatie van het IMOBallastwaterverdrag in nationale wet- en regelgeving in 2017 en het stellen van voorwaarden aan de vergunningen voor schelpdiertransport. 


\subsubsection{Visserij: vangst en bijvangst}

\section{Huidige toestand en trend}

De beoordeling van de gevolgen van visserij voor vis is binnen de KRM uitgewerkt in Descriptor D3 (commerciële vis, schaal- en schelpdieren). Voor deze Descriptor gelden criteria gericht op visserijsterfte (D3C1) en paaibestanden (D3C2), zie Tabel 14. In het commissiebesluit 2017/848 (EC, 2017) staat nog een derde criterium voor deze descriptor: D3C3 De leeftijdsopbouw en grootteverdeling van individuele exemplaren in de populaties van commercieel geëxploiteerde soorten duiden op een gezonde populatie. Dit betekent onder meer een hoog percentage oude/grote exemplaren en een beperkte negatieve invloed van de exploitatie op de genetische diversiteit. $\mathrm{Er}$ bestaan echter nog onduidelijkheden en strijdigheid tussen de doelstelling omtrent MSY (GVB, D3C1 en D3C2) enerzijds en de soort-specifieke leeftijds- en grootteverdeling (D3C3) anderzijds. ICES heeft daarom geconcludeerd dat dit criterium nog verdere uitwerking behoeft en Nederland zal in dit stadium D3C3 niet implementeren (Ministerie van I\&W en LNV, 2018). De doelstelling voor commerciële visbestanden is niet gehaald (Tabel 14). Wel wordt voldaan aan de gestelde limiet voor de geschatte jaarlijkse bijvangst van bruinvis in de Noordzee (D1C1), zie ook paragraaf 4.2.1 (zeezoogdieren).

Tabel 14 Toestandsbeoordeling KRM descriptor 3, commerciële vis, schaal- en schelpdieren (gebaseerd op Ministerie van I\&W en LNV, 2018). De status geeft aan of de goede milieutoestand is gehaald (goed), niet gehaald (niet goed), nog niet bekend is vanwege bijvoorbeeld het ontbreken van vastgestelde grenswaarden/streefwaarden (onbekend).

\begin{tabular}{|l|l|l|l|}
\hline Criteria & Goede milieutoestand & Indicator & Status \\
\hline D3C1 & $\begin{array}{l}\text { Voor ieder commercieel bevist visbestand geldt dat de sterfte } \\
\text { door visserij (F) op de waarde of kleiner dan de waarde blijft } \\
\text { die behoort bij een maximale duurzame oogst (Maximum } \\
\text { Sustainable Yield, MSY): F SFmsy (CFP). }\end{array}$ & Visserij mortaliteit \\
\hline D3C2 & $\begin{array}{l}\text { De biomassa van paaibestanden (Spawning Stock Biomass of } \\
\text { SSB) van commercieel beviste vis, schaal- of schelpdieren } \\
\text { ligt boven het voorzorgniveau MSY Btrigger (in lijn met ICES- } \\
\text { vangstadviezen; CFP). }\end{array}$ & Paai biomassa \\
\hline D3C3* & $\begin{array}{l}\text { De leeftijdsopbouw en grootteverdeling van individuele } \\
\text { exemplaren in de populaties van commercieel geëxploiteerde } \\
\text { soorten duiden op een gezonde populatie }\end{array}$ & $*$ & \\
\hline D1C1 & $\begin{array}{l}\text { Bijvangst van bruinvissen is lager dan 1 procent van de best } \\
\text { bruikbare populatieschatting (ASCOBANS). }\end{array}$ & $\begin{array}{l}\text { OSPAR - Bruinvisbijvangst } \\
\text { (M6) }\end{array}$ & Goed \\
\hline
\end{tabular}

* dit criterium behoeft nog verdere uitwerking en Nederland heeft in dit stadium D3C3 niet geïmplementeerd

Internationaal is afgesproken dat de goede milieutoestand voor commerciële vissoorten is verwezenlijkt wanneer voor elk commercieel bevist bestand aan deze beide criteria (visserijmortaliteit ( $F \leq F M S Y$ ) en paaibiomassa (SSB $\geq S S B M S Y)$ ) wordt voldaan. Als dat niet het geval is, verkeert de soort niet in de goede toestand. Momenteel voldoen slechts $26 \%$ van de soorten aan beide criteria (Figuur 32), zodat de GMT nog niet is bereikt (Ministerie van I\&W en LNV, 2018, Tabel 14). Over de tijd is er sinds de mid-90er jaren wel een herstel te zien waarbij de visserijmortaliteit omlaag is gegaan waardoor de bestanden geleidelijk weer zijn gaan herstellen (zie Figuur 33). 


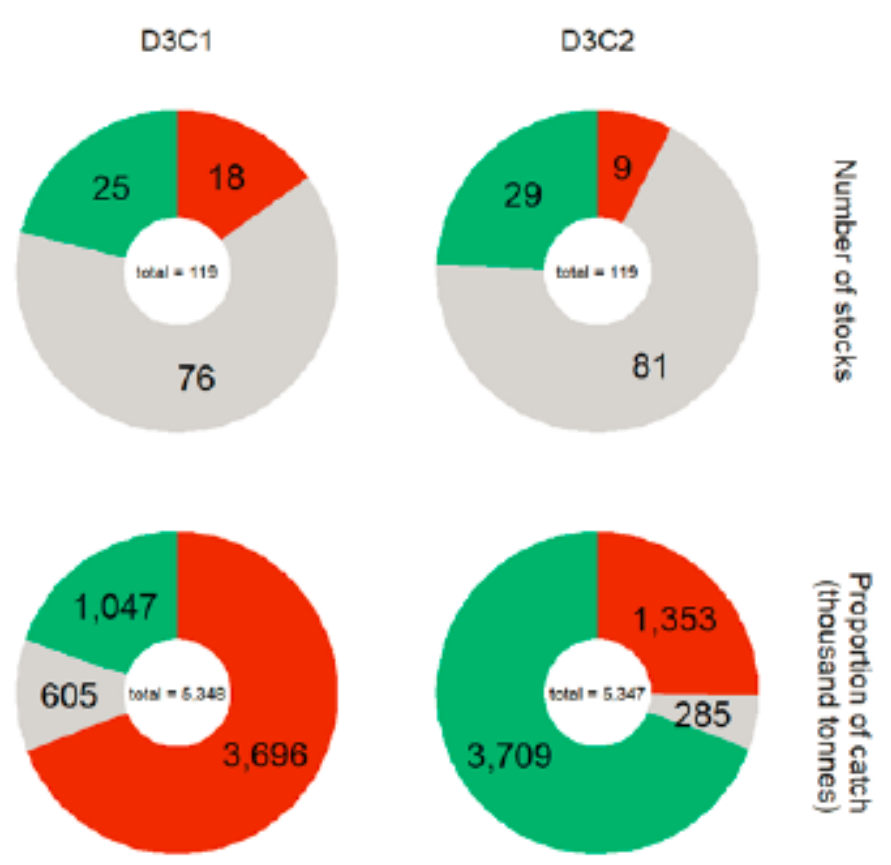

ICES Stock Assessment Database, 2018November. ICES, Copenhagen

Figuur 32 Samenvatting van de status van visbestanden in de gehele Noordzee in relatie tot de GMT criteria voor visserijdruk (D3C1) en paaibiomassa (D3C2). De mate waarin aan de criteria wordt voldaan (per fractie van de soorten) is aangegeven door middel van kleuren, waarbij groen aan de criteria wordt voldaan, rood wordt niet voldaan aan de criteria en grijs is onbekend (ICES, 2018).

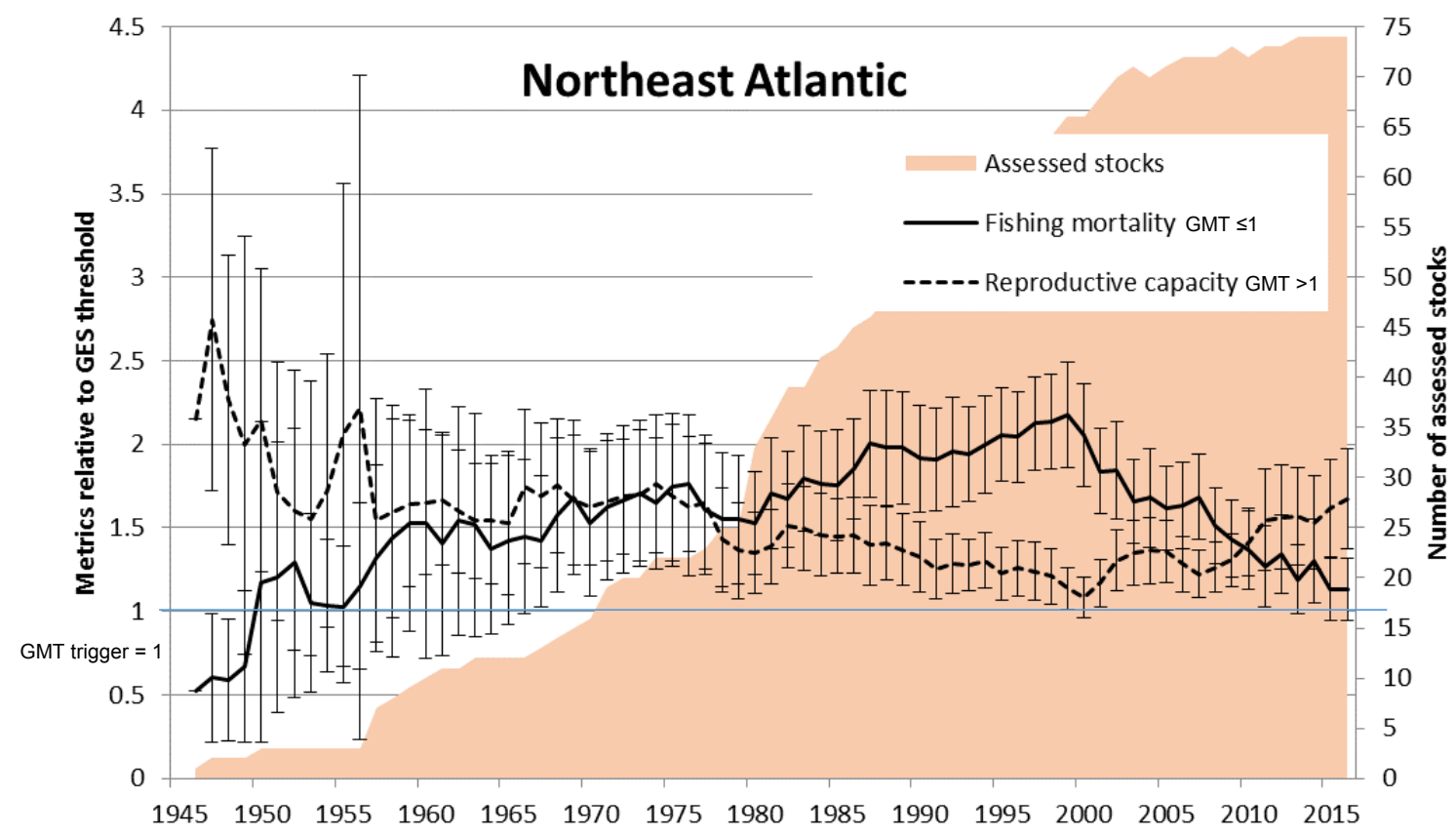

Figuur 33 Tijdserie van het gemiddelde over alle commerciële visbestanden van de twee indicatoren die de GMT bepalen: visserij mortaliteit en paaibiomassa relatief t.o.v. het niveau dat hoort bij de doelstelling van maximale duurzame oogst. Om de GMT te bereiken moet visserijmortaliteit $\leq 1$ (liefst=1) zijn terwijl de paaibiomassa > 1 (liefst zoveel mogelijk) moet zijn. 


\section{Belangrijke activiteiten en drukfactoren}

Activiteiten die een risico vormen voor commerciële visbestanden (op basis van alleen directe relaties) zijn logischerwijze alle visserijvormen (Figuur 34). De CEA onderscheidt drie typen visserij, hier genoemd in volgorde van afnemend risico op impact: benthische visserij (incl. mechanische schelpdiervisserij), staandwant visserij (netten, korven, manden) en pelagische visserij (incl. lange lijnvisserij). De GMT is gericht op soorten en niet op visserijmethoden. Wel kan er aan de hand van de status van de doelsoorten een indicatie van de belangrijkste visserijvormen worden gegeven (Figuur 35 en Tabel 15). Voor bentische soorten zijn er relatief meer soorten die GES hebben bereikt ten opzichte van soorten die nog geen GMT hebben bereikt (Figuur 35). Voor pelagische soorten geldt het omgekeerde. Op basis van de GMT analyse per soort en de Nederlandse visserij waarbij die soorten (kunnen) worden gevangen (Tabel 15), lijkt er geen visserijvorm te zijn die uitsluitend vissoorten vangt die een GMT hebben bereikt.

Naast de onttrekking van doelsoorten (vangst) heeft ook bijvangst gevolgen voor de natuur (o.a. Röckmann et al., 2011). Met bijvangst wordt bedoeld de vangst van soorten die niet tot de doelsoorten behoren of niet aan bepaalde vangstcriteria voldoen. Bijvangst kan dus bestaan uit andere soorten dan de doelsoorten, welke ook worden aangeland. $\mathrm{Er}$ is ook ongewenste bijvangst en dat is alles wat gevangen wordt maar niet gewenst is en vervolgens terug overboord wordt gezet. Dit laatste wordt discards, of teruggooi, genoemd. Bijvoorbeeld in de boomkor- en bordenvisserij met 80-99 mm maaswijdte bestaat de vangst van schol uit ongeveer de helft aanlandingen en de andere helft uit discards (van Helmond \& Steins, 2016). Maatregelen zijn dan ook, naast het reguleren van de vangst, met name gericht op het terugdringen van bijvangst en daarmee de discards, zie beleidsmaatregelen hieronder.

Bijvangst speelt niet alleen een rol voor vis, maar ook voor benthos, zeezoogdieren en vogels. In geval van de bijvangst van zeezoogdieren en vogels gaat het vooral om het gevaar van verdrinking in vaste vistuigen zoals staand want en fuiken (Polet et al., 2010; Polet \& Depestele, 2010).

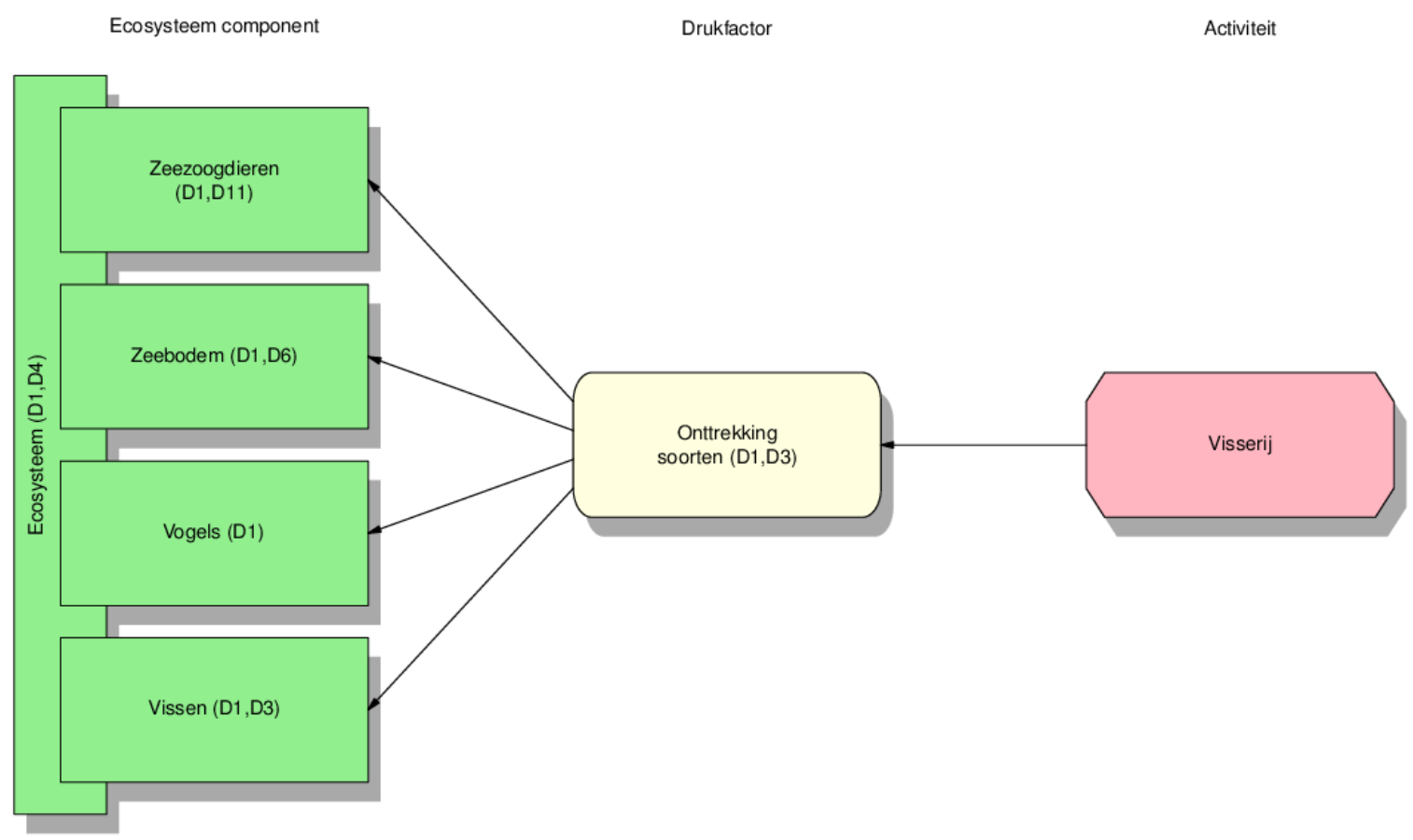

Figuur 34 De drukfactor 'onttrekking van soorten', de activiteiten die daar invloed op hebben en de gerelateerde onderdelen van het Noordzee ecosysteem. De relaties zijn zoveel mogelijk gebaseerd op informatie vanuit de Nederlandse KRM (Ministerie van IenM en EZ, 2014; Ministerie van I\&W en LNV, 2018). D1 Biodiversiteit; D2 Niet-inheemse soorten; D3 Commerciële visbestanden; D4 Voedselweb; D5 Eutrofiering; D6 Bodemintegriteit; D7 Hydrografische eigenschappen; D8 Vervuilende stoffen; D9 Vervuilende stoffen in vis; D10 Zwerfvuil; D11 Energietoevoer, o.m. onderwatergeluid. 


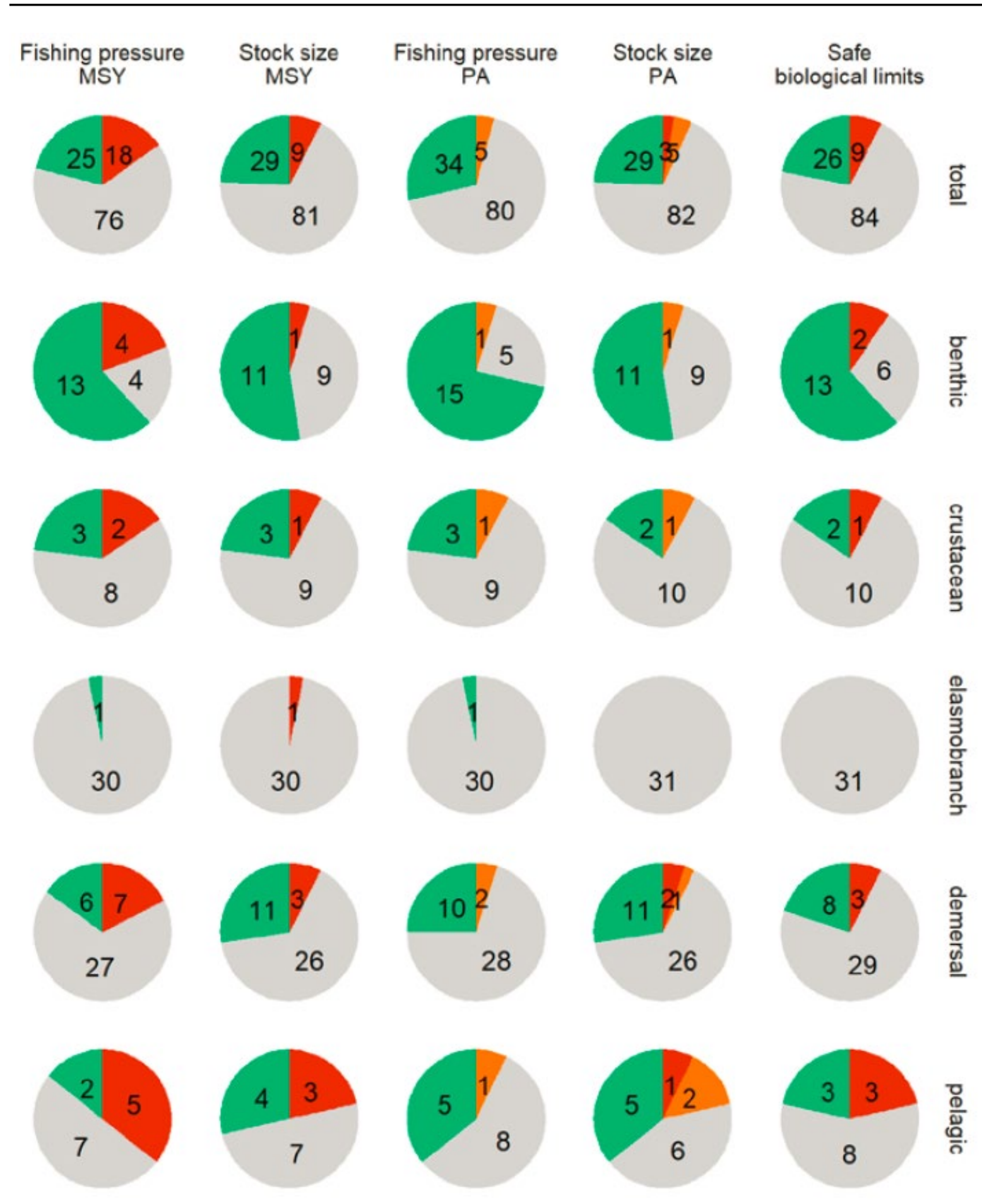

ICES Stock Assessment Database, November 2018. ICES, Copenhagen

Figuur 35 Samenvatting van de status van visbestanden in de gehele Noordzee in relatie tot de GMT criteria voor visserijdruk (D3C1) en paaibiomassa (D3C2). Hierbij is onderscheid gemaakt tussen de verschillende soortgroepen. De mate warin aan de criteria wordt voldaan (per fractie van de soorten) is aangegeven door middel van kleuren, waarbij groen aan de criteria wordt voldaan, rood wordt niet voldaan aan de criteria en grijs is onbekend (ICES, 2018). 
Tabel 15 Vissoorten die op het Nederlandse deel van de Noordzee (ICES gebied 4 ( $b$ en $c)$ ) door ICES zijn beoordeeld op de twee afzonderlijke KRM criteria ( $D 3 C 1$ : visserijmortaliteit ( $F \leq F M S Y)$ en D3C2: paaibiomassa (SSB $\geq S S B M S Y$ )) en de uiteindelijke GES (Good Environmental Status, ofwel GMT) (ICES, 2018). Voor elke soort zijn de visserijvormen genoemd op basis van de gemiddelde vangstsamenstelling van de Nederlandse zeevisserij per tuigcategorie (van Helmond \& Steins, 2016). NB. een soort kan ook slechts een zeer klein deel (<1\%) van de totale vangst zijn

\begin{tabular}{|c|c|c|c|c|}
\hline Soort & Visserijvormen & D3C1 & D3C2 & GES \\
\hline Blauwe wijting & Pelagisch & $x$ & $\sqrt{ }$ & $x$ \\
\hline Bot & Boomkor, staand want & $\sqrt{ }$ & $?$ & $?$ \\
\hline Doornhaai & - & $\sqrt{ }$ & $\mathrm{x}$ & $\mathrm{x}$ \\
\hline Europese aal & Korven & $?$ & $x$ & $?$ \\
\hline Griet & Boomkor, borden, staand want & $\sqrt{ }$ & $\sqrt{ }$ & $\sqrt{ }$ \\
\hline Haring & Pelagisch, garnalen, flyshoot & $\sqrt{ }$ & $\sqrt{ }$ & $\sqrt{ }$ \\
\hline Heek & Pelagisch & $\sqrt{ }$ & $\sqrt{ }$ & $\sqrt{ }$ \\
\hline Horsmakreel & Pelagisch, flyshoot, borden & $\mathrm{x}$ & $?$ & $?$ \\
\hline Kabeljauw & Boomkor, borden, flyshoot, staand want, handlijnen & $x$ & $x$ & $x$ \\
\hline Koolvis & Flyshoot, handlijnen & $\sqrt{ }$ & $\sqrt{ }$ & $\sqrt{ }$ \\
\hline Leng & - & $\sqrt{ }$ & $?$ & $?$ \\
\hline Lom & - & $\sqrt{ }$ & $\sqrt{ }$ & $\sqrt{ }$ \\
\hline Makreel & Jiggen, pelagisch, flyshoot, handlijnen, borden & $\mathrm{x}$ & $\mathrm{x}$ & $x$ \\
\hline Mul & Flyshoot & $\mathrm{x}$ & $?$ & $?$ \\
\hline Noorse kreeft & Borden, flyshoot & $\mathrm{x}$ & $\sqrt{ }$ & $?$ \\
\hline Schar & Boomkor, borden, flyshoot & $\sqrt{ }$ & $\sqrt{ }$ & $\sqrt{ }$ \\
\hline Schelvis & Flyshoot & $x$ & $\sqrt{ }$ & $x$ \\
\hline Schol & Boomkor, borden, flyshoot, garnalen, staand want & $\sqrt{ }$ & $\sqrt{ }$ & $\sqrt{ }$ \\
\hline Sprot & Garnalenvisserij & $\mathrm{x}$ & $\sqrt{ }$ & $\mathrm{x}$ \\
\hline Tarbot & Boomkor, borden & $\sqrt{ }$ & $\sqrt{ }$ & $\sqrt{ }$ \\
\hline Tong & Boomkor, staand want, borden & $\sqrt{ }$ & $\sqrt{ }$ & $\sqrt{ }$ \\
\hline Tongschar & Boomkor, borden, flyshoot & $\sqrt{ }$ & $\sqrt{ }$ & $\sqrt{ }$ \\
\hline Wijting & Boomkor, borden, flyshoot, staand want, garnalen & $x$ & $\sqrt{ }$ & $x$ \\
\hline Witje (aalbot) & Flyshoot & $\sqrt{ }$ & $\sqrt{ }$ & $\sqrt{ }$ \\
\hline Zandspiering & - & $?$ & $\sqrt{ }$ & $?$ \\
\hline Zeebaars & Flyshoot, staand want, jiggen, handlijnen & $\sqrt{ }$ & $\mathrm{x}$ & $\mathrm{x}$ \\
\hline
\end{tabular}

\section{Milieudoelen en beleidsmaatregelen}

Het milieudoel om de voortgang tot GMT voor commerciële visbestanden te begeleiden is (Ministerie van I\&W en LNV, 2018):

- D3T1: het beheer van alle commercieel beviste bestanden voldoet aan een visserijsterfte F $\leq$ Fmsy en een paaibiomassa boven het voorzorgniveau MSY Btrigger.

De selectie van maatregelen uit het programma van maatregelen (2015), zoals aangegeven door het Ministerie van I\&W en LNV (2018):

- $\quad$ vangstbeheer commerciële visserij;

- aanlandplicht;

- $\quad$ stimulering alternatieve vistuigen (zoals puls-techniek);

- certificering.

In de Mariene Strategie (Ministerie van I\&W en LNV, 2018) is geconcludeerd dat het bestaand beleid zou moeten voldoen om de GMT voor commerciële visbestanden te behalen. Volgens het GVB van de Europese Unie moeten de visbestanden bevist worden volgens het idee van "maximaal duurzame oogst" (Maximum Sustainable Yield, MSY) (Europese Commissie, 2014). Het streeft naar een duurzaam voortbestaan van de visbestanden en naar een evenwichtige exploitatie door de visserij. De beleidsmaatregelen omvatten vooral de toepassing van toegestane jaarlijkse vangsthoeveelheden (total allowable catch- TAC's) en beperkingen aan de capaciteit en de inzet van de visserijvloot. Ook wordt teruggooi (discarding) gereguleerd door middel van de aanlandplicht, die stapsgewijs tussen 2015 en 2019 wordt ingevoerd voor verschillende soorten en visserijen (Steins et al., 2018).

Nederland is een van de landen die het meest getroffen zal worden door de aanlandplicht (Catchpole et al., 2017). Dit geldt met name voor de metiers met hoge bijvangst percentages, te weten boomkor 80-99 mm maaswijdte (doelsoort tong) en bordenvisserij 80-99 mm (doelsoort Noorse kreeft) (van Helmond \& Steins, 2016). Het belangrijkste doel van de aanlandplicht is om (voedsel)verspilling tegen te gaan door een verbod op de praktijk van het overboord gooien van ongewenste bijvangsten van ondermaatse gequoteerde vis, of van vis waarvoor de visser geen quotum heeft (Steins et al., 2018). Er bestaat echter ook een kans dat de maatregel niet goed wordt geïmplementeerd en dus niet tot minder bijvangst zal leiden (dwz. dat de visserij gewoon zal doorgaan en dat de vangst boven de 
quota komt en de minst waardevolle maten overboord gaan) (Batsleer et al., 2016). Een ander mogelijk gevolg is een toename van visserijsterfte voor niet-doelsoorten, zoals bijvoorbeeld voor schar (van Helmond \& Steins, 2016). Innovatieve vistuigen zouden de selectiviteit van de visserij moeten kunnen verbeteren (Catchpole et al., 2017).

\subsubsection{Eutrofiëring}

\section{Huidige toestand en trend}

Het overkoepelend doel voor eutrofiëring is drieledig:

1. de concentraties van winter DIN (Dissolved Inorganic Nitrogen: opgelost anorganisch stikstof) en DIP (Dissolved Inorganic Phosphate: opgelost anorganisch fosfaat) liggen onder het niveau dat wijst op schadelijke eutrofiëringseffecten (D5C1);

2. algenbiomassa (vastgesteld op basis van chlorofyl-a-metingen) ligt niet op een niveau dat wijst op schadelijke effecten van verrijking met nutriënten, conform de beoordeling volgens de KRW en OSPAR (D5C2).

3. geen zuurstofgebrek ten gevolge van eutrofiëring in onderste waterlaag (gestratificeerde wateren) of in de oppervlaktelaag van gemengde wateren (D5C5).

Nederland heeft besloten om het vóórkomen van Phaeocystis-bloeien (D5C3) niet meer te gebruiken voor de beoordeling van eutrofiering, omdat dit geen goede indicator is voor eutrofiering.

De KRM doelstelling voor eutrofiëring is grotendeels gehaald (Tabel 16). Alleen de nutriëntenconcentraties in de kustzone voldoen nog niet aan de normen van de KRW en OSPAR. Ook voldoen niet alle waterlichamen in de kustwateren volgens de KRW aan de chlorofyl-a norm. Op schaal van de zuidelijke Noordzee (de OSPAR beoordeling) voldoet de algenbiomassa aan de norm, zowel offshore als aan de kust. Voor eutrofiëring is een KRM Artikel $14^{2}$ uitzondering gerapporteerd (Ministerie van I\&W en LNV, 2018).

Tabel 16 Toestandsbeoordeling KRM descriptor 5, eutrofiëring (gebaseerd op Ministerie van I\&W en $L N V, 2018$ ). De status geeft aan of de goede milieutoestand is gehaald (goed), niet gehaald (niet goed), nog niet bekend is vanwege bijvoorbeeld het ontbreken van vastgestelde grenswaarden/streefwaarden (onbekend).

\begin{tabular}{|c|c|c|c|}
\hline Criteria & Goede milieutoestand & Indicator & Status \\
\hline \multicolumn{4}{|c|}{ Kustwateren } \\
\hline D5C1 & $\begin{array}{l}\text { De nutriëntenconcentraties in de winter voldoen in de } \\
\text { kustwateren aan de normen van de KRW }\end{array}$ & $\mathrm{NL}-\mathrm{KRW}$-beoordeling & Niet goed \\
\hline D5C2 & $\begin{array}{l}\text { Algenbiomassa (vastgesteld op basis van chlorofyl-a metingen) } \\
\text { in de kustwateren is niet hoger dan de goede toestand conform } \\
\text { de KRW voor de desbetreffende kustwatertypen }\end{array}$ & $\mathrm{NL}-\mathrm{KRW}$-beoordeling & Niet goed \\
\hline \multirow[t]{2}{*}{ D5C5 } & $\begin{array}{l}\text { De onderste waterlaag (gestratificeerde wateren) of de } \\
\text { oppervlaktelaag van gemengde wateren in de kustwateren is } \\
\text { ten minste met } 60 \text { procent zuurstof verzadigd }\end{array}$ & $\mathrm{NL}-\mathrm{KRW}$-beoordeling & Goed \\
\hline & $\begin{array}{l}\text { In de kustwateren wordt in de onderste waterlaag (stratified } \\
\text { waters) of in de oppervlaktelaag van gemengde wateren ten } \\
\text { minste } 6 \mathrm{mg} / \mathrm{l} \text { zuurstof gevonden }\end{array}$ & $\begin{array}{l}\text { OSPAR Opgeloste } \\
\text { zuurstofconcentraties }\end{array}$ & Goed \\
\hline D5C2 & $\begin{array}{l}\text { Algenbiomassa (vastgesteld op basis van chlorofyl-a metingen) } \\
\text { in de offshore wateren voldoen aan de beoordelingswaarden } \\
\text { van OSPAR. }\end{array}$ & OSPAR Chlorofylconcentraties & Goed \\
\hline D5C5 & $\begin{array}{l}\text { In de offshore wateren wordt in de onderste waterlaag } \\
\text { (gestratificeerde wateren) of in de oppervlaktelaag van } \\
\text { gemengde wateren ten minste } 6 \mathrm{mg} / \mathrm{l} \text { zuurstof gevonden. }\end{array}$ & $\begin{array}{l}\text { OSPAR Opgeloste } \\
\text { zuurstofconcentraties }\end{array}$ & Goed \\
\hline
\end{tabular}

\footnotetext{
${ }^{2}$ De Kaderrichtlijn mariene strategie bevat een aantal uitzonderingen waarop lidstaten zich kunnen beroepen wanneer niet in alle opzichten aan de richtlijn kan worden voldaan. Het kan daarbij gaan om (het uitblijven van) maatregelen waarvoor de lidstaat niet verantwoordelijk is; natuurlijke oorzaken; overmacht; redenen van dwingend openbaar belang; en natuurlijke omstandigheden (artikel 14 lid 1). Daarnaast is er een uitzondering voor het ontwikkelen van (bepaalde) elementen van de mariene strategieën in situaties waarbij er geen significant risico is voor het mariene milieu of wanneer de kosten onevenredig zijn, onder de voorwaarde dat er geen verdere achteruitgang is (artikel 14 lid 4).
} 
Door een breed internationaal / regionaal pakket aan maatregelen met betrekking tot beperking van de toevoer van nutriënten zijn de concentraties van stikstof (Figuur 36) en fosfaat (Figuur 37) in het Noordzeewater significant lager dan in 1990, met als gevolg dat ook de hoeveelheid algenbiomassa over de periode 2006-2014 significant is afgenomen (Figuur 38).

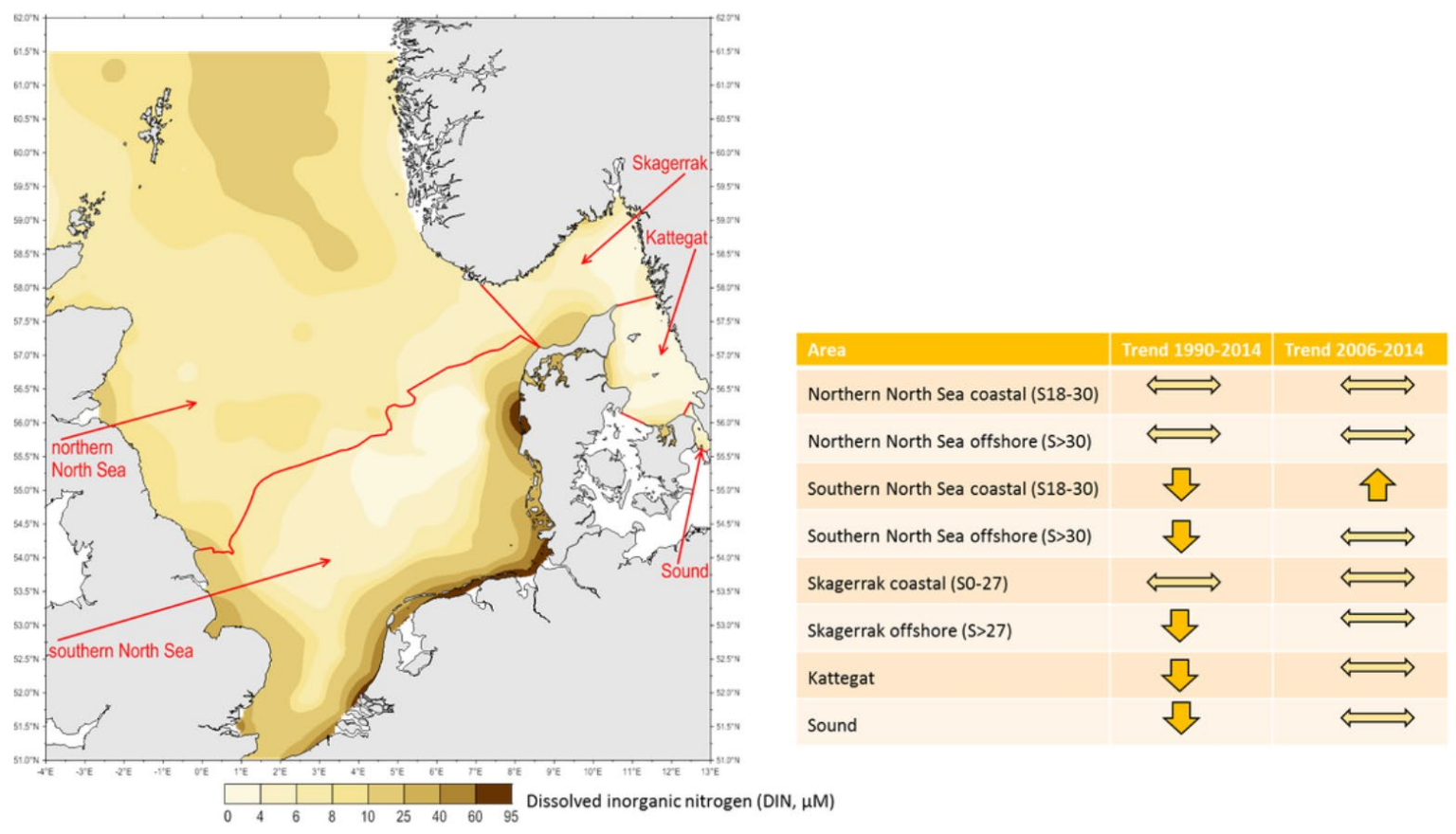

Figuur 36 OSPAR Indicator Nutriëntconcentraties: Verspreiding van gemiddelde concentraties (20062014) opgelost anorganisch stikstof $(\mu M)$ in de winter in de Noordelijke Noordzee, de Zuidelijke Noordzee, het Skagerrak, het Kattegat en de Sound (OSPAR, 2017). Witte gebieden zijn niet meegenomen in de beoordeling. De bijbehorende tabel geeft de resultaten van de trendanalyses weer voor de periode 1990-2014 en 2006-2014. Een neerwaartse pijl geeft een significant afnemende trend aan, een opwaartse pijl een significant toenemende trend en een horizontale pijl geeft aan dat er geen statisch significante trend is vastgesteld. 


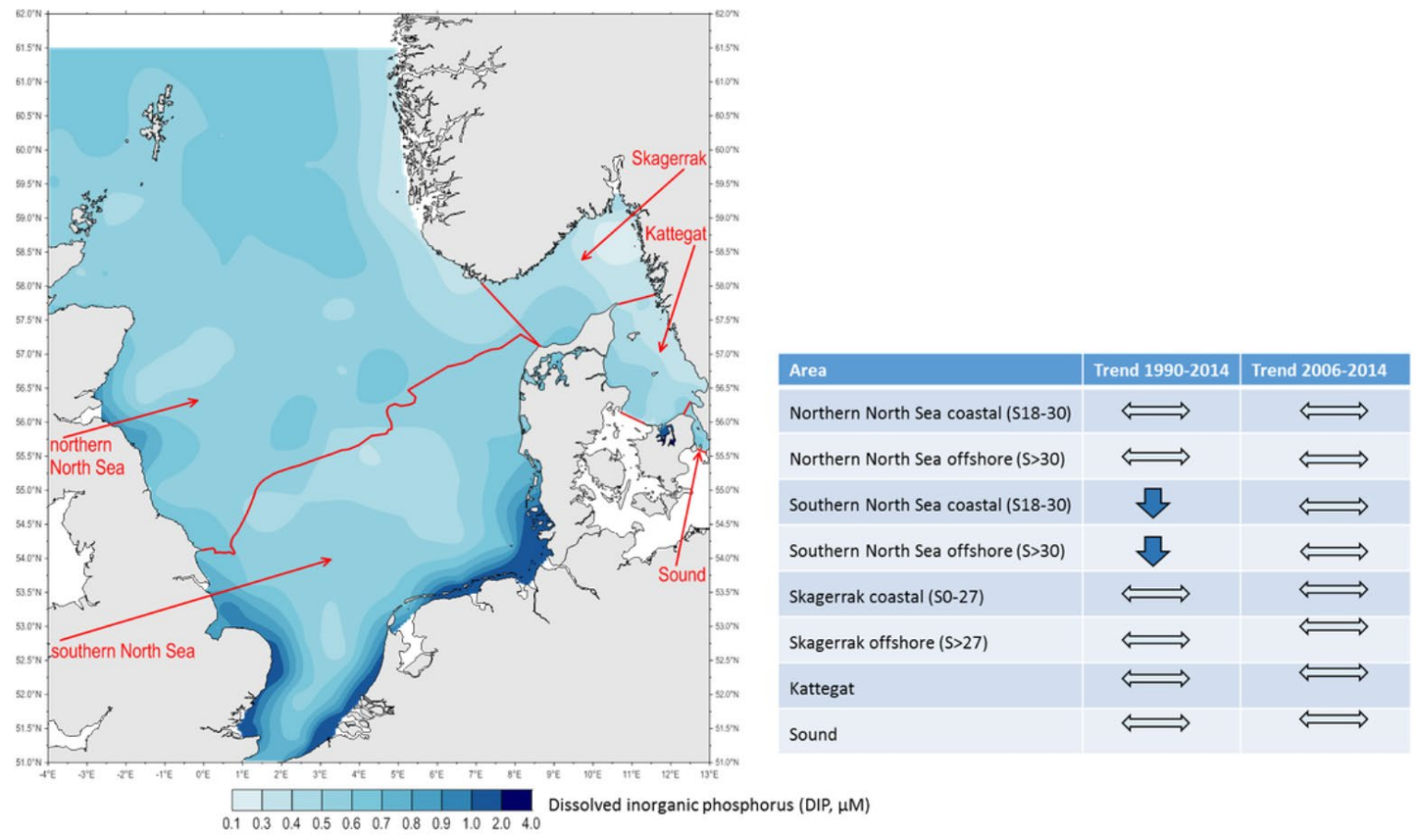

Figuur 37 OSPAR Indicator Nutriëntconcentraties: Verspreiding van gemiddelde concentraties (20062014) opgelost anorganisch fosfaat $(\mu M)$ in de winter in de Noordelijke Noordzee, de Zuidelijke Noordzee, het Skagerrak, het Kattegat en de Sound (OSPAR, 2017). Witte gebieden zijn niet meegenomen in de beoordeling. De bijbehorende tabel geeft de resultaten van de trendanalyses weer voor de periode 1990-2014 en 2006-2014. Een neerwaartse pijl geeft een significant afnemende trend aan, een opwaartse pijl een significant toenemende trend en een horizontale pijl geeft aan dat er geen statisch significante trend is vastgesteld.
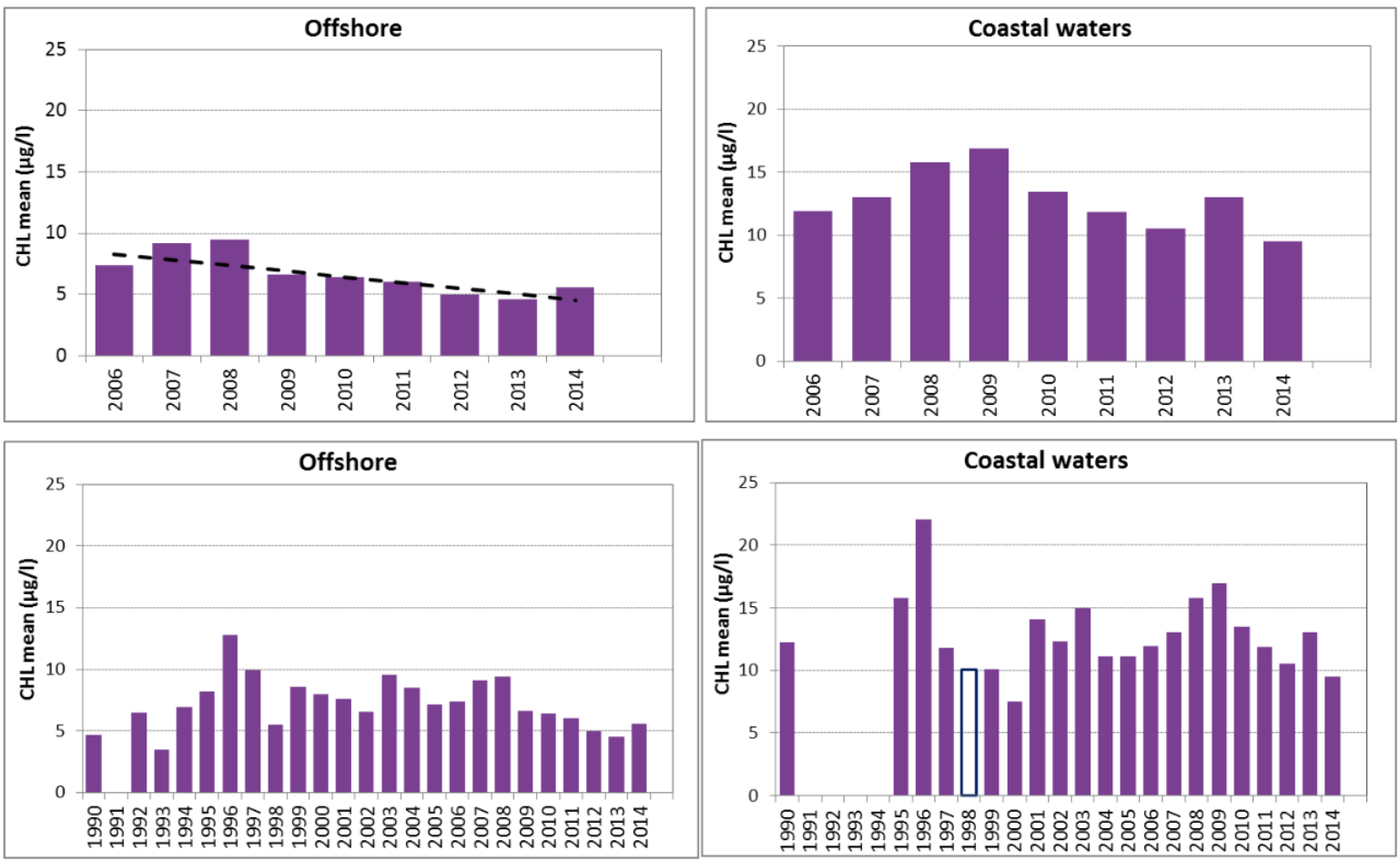

Figuur 38 OSPAR Indicator Chlorofylconcentraties: De 90-percentiel groeiseizoen (maart-september) chlorofyl-a concentraties in de OSPAR sub-gebieden van de zuidelijke Noordzee offshore (saliniteit $\geq 30$ ) en kustzone (coastal waters) (saliniteit 18 tot <30) over de gehele periode 1990-2014 (onderste figuren) en de periode 2006-2014 (bovenste figuur). Gekleurde balken zijn gebaseerd op jaren met tenminste 5 observatiemaanden; witte balken zijn jaren met 3 of 4 observatiemaanden. De stippellijn geeft een statisch significante lineaire trend $(p<0.05)$ aan $($ OSPAR, 2017). 
Er worden in Nederland regelmatig bloeien waargenomen van de plaagalg Phaeocystis (Figuur 39) waardoor het Nederlandse deel van de Noordzee in de OSPAR-beoordeling als 'probleemgebied' is aangeduid. Phaeocystis veroorzaakt schuimvorming aan het einde van een bloei. Alhoewel OSPAR de bloei van deze alg als indicator voor eutrofiëring hanteert, neemt Nederland deze niet mee in de beoordeling omdat het niet als een goede en betrouwbare indicator voor eutrofiëringseffecten wordt beschouwd (Ministerie van I\&W en LNV, 2018).

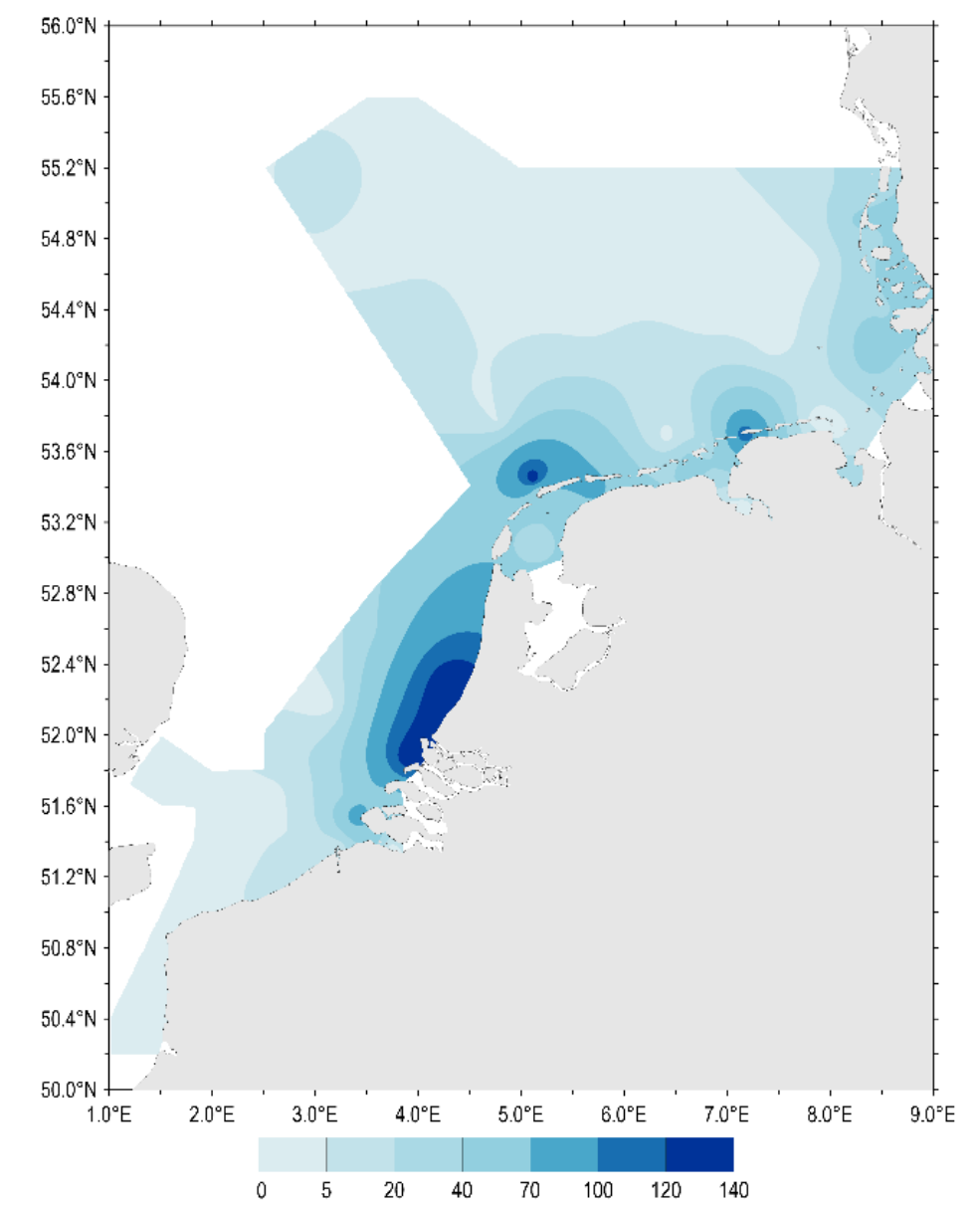

Figuur 39 Gradiënten van maximale Phaeocystis concentraties (miljoen cellen per liter) in de periode april-augustus (alle beschikbare jaren en monitoring locaties 1990-2014) (OSPAR, 2017).

\section{Belangrijke activiteiten en drukfactoren}

De belangrijkste activiteiten die bijdragen aan de toevoer van stikstof en fosfaat (het risico voor eutrofiëring) die zijn geïdentificeerd aan de hand van de CEA zijn activiteiten op land (landbouw en waterzuivering), bodemberoerende visserij (die zorgt voor resuspensie van sediment), toerisme en recreatie, en scheepvaart. Bij de Nederlandse KRM wordt uitgegaan van grotendeels dezelfde activiteiten (Figuur 40). 


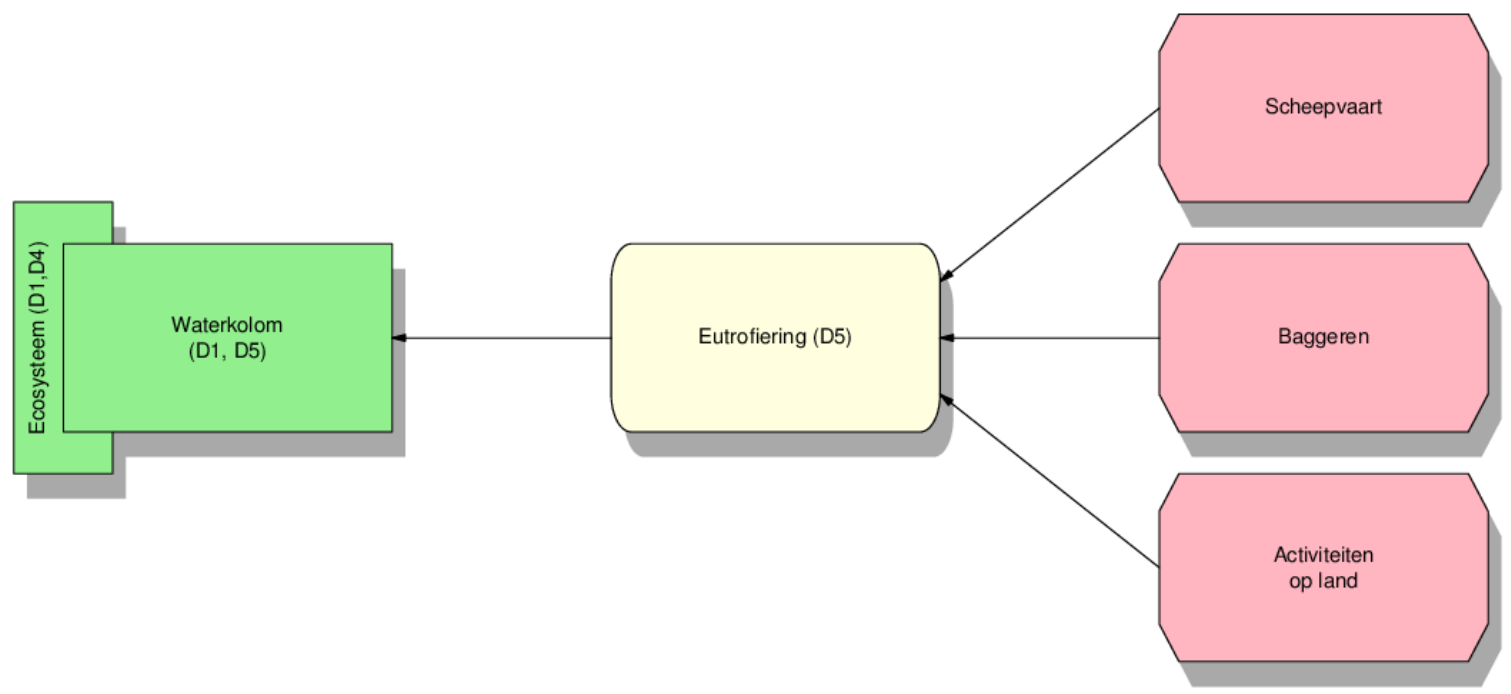

Figuur 40 De drukfactor 'eutrofiëring', de activiteiten die daar invloed op hebben en de gerelateerde onderdelen van het Noordzee ecosysteem. De relaties zijn zoveel mogelijk gebaseerd op informatie vanuit de Nederlandse KRM (Ministerie van IenM en EZ, 2014; Ministerie van I\&W en LNV, 2018). D1 Biodiversiteit; D2 Niet-inheemse soorten; D3 Commerciële visbestanden; D4 Voedselweb; D5 Eutrofiering; D6 Bodemintegriteit; D7 Hydrografische eigenschappen; D8 Vervuilende stoffen; D9 Vervuilende stoffen in vis; D10 Zwerfvuil; D11 Energietoevoer, o.m. onderwatergeluid.

\section{Milieudoelen en beleidsmaatregelen}

De milieudoelen om de voortgang tot GMT voor eutrofiëring te begeleiden zijn (Ministerie van I\&W en LNV, 2018):

- D5T1: lagere toevoer van nutriënten waar deze niet aan de doelen van de KRW voldoen conform het tijdspad van de stroomgebied-beheerplannen.

- D5T2: concentraties van nutriënten die al voldoen aan de KRW-normen, niet laten toenemen en de toevoer ervan zo mogelijk verder verlagen.

De selectie van maatregelen uit het programma van maatregelen (2015), zoals aangegeven door het Ministerie van I\&W en LNV (2018):

- uitvoering Annex V MARPOL, reductie emissies;

- maatregelen op grond van Kaderrichtlijn Water met betrekking tot de landbouw, stedelijk afvalwater en rioolwaterzuiveringsinstallaties

Om stagnatie te voorkomen is het verder terugdringen van nutriënten ook een van de prioriteiten van de Delta-aanpak waterkwaliteit en zoetwater (Ministerie van I\&W en LNV (2018).

In de Mariene Strategie (Ministerie van I\&W en LNV, 2018) is geconcludeerd dat het bestaand beleid voldoet om de GMT voor eutrofiëring te behalen, naar verwachting bereikbaar in de jaren na 2020. Wel is er een kennisopgave met betrekking tot de verhouding fosfaat-stikstof (Ministerie van I\&W en LNV, 2018). 


\subsubsection{Verstoring en verlies zeebodem}

\section{Huidige toestand en trend}

De twee onderdelen fysiek verlies en fysieke verstoring bepalen samen de KRM Descriptor D6 (zeebodemintegriteit). Of de KRM doelstelling voor zeebodemintegriteit is gehaald is door ontbreken van geschikte grenswaarden vooralsnog niet vast te stellen (Tabel 17). Onder deze tabel wordt nader ingegaan op de status van de criteria.

Tabel 17 Toestandsbeoordeling KRM descriptor 6, Zeebodemintegriteit (gebaseerd op Ministerie van I\&W en LNV, 2018). De status geeft aan of de goede milieutoestand is gehaald (goed), niet gehaald (niet goed), nog niet bekend is vanwege bijvoorbeeld het ontbreken van vastgestelde grenswaarden/streefwaarden (onbekend).

\begin{tabular}{|c|c|c|c|}
\hline Criteria & Goede milieutoestand & Indicator & Status \\
\hline D6C4 & $\begin{array}{l}\text { Geen significant verlies als gevolg van menselijke activiteiten } \\
\text { van de habitats die in het kader van de KRM beschreven zijn. }\end{array}$ & $\begin{array}{l}\mathrm{NL} \text { - D6 - Spreiding en } \\
\text { ruimtelijke omvang fysiek } \\
\text { verlies. }\end{array}$ & $\begin{array}{l}\text { Waarschijnlijk } \\
\text { goed }\end{array}$ \\
\hline D6C3 & $\begin{array}{l}\text { Geen toename in de fysieke verstoring in de tijd over de } \\
\text { habitats die in het kader van de KRM zijn beschreven. }\end{array}$ & $\begin{array}{l}\text { ICES/NLD6 - } \\
\text { Visserijdrukindicator. }\end{array}$ & Onbekend \\
\hline D6C3\# & $\begin{array}{l}\text { Voor de habitats die in het kader van de habitatrichtlijn zijn } \\
\text { beschreven, gelden de instandhoudingsdoelen voor deze } \\
\text { habitats. }\end{array}$ & $\begin{array}{l}\mathrm{NL}-\mathrm{HR} \text { beoordeling } \\
\mathrm{H} 1110 \text { en } \mathrm{H} 1170\end{array}$ & Niet goed* \\
\hline
\end{tabular}

* Op basis van voorlopige resultaten EU Habitatrichtlijn beoordeling over de periode 2013-2018

** Status nog niet vast te stellen doordat de evaluatie van de BISI bemonstering van 2018 nog niet is uitgevoerd. Op basis van indicatieve

trends lijkt het er echter erop dat in 2018 nog niet voldaan wordt aan GMT (Ministerie van I\&W en LNV, 2018).

\# Dit criterium staat beschreven onder de toestand van de zeebodem (paragraaf 4.2.4)

\section{Fysiek verlies}

Het verlies aan natuurlijke zeebodem door landaanwinning, de aanleg van platforms voor olie- en gaswinning, windparken en kruisingen van kabels en leidingen sinds 2012 is 0,55 km² (zie ook de tekst onder het kopje 'belangrijke activiteiten en drukfactoren', verderop in deze paragraaf). Dit is $0,001 \%$ van de totale Nederlandse Noordzee $\left(58.000 \mathrm{~km}^{2}\right)$. Hieruit volgt dat er geen significant verlies van de natuurlijke zeebodem is opgetreden sinds 2012. Er is geen berekening gedaan van het verlies per habitattype. Wel wordt in de Mariene Strategie (Ministerie van I\&W en LNV, 2018) aangegeven dat het onwaarschijnlijk lijkt dat er sprake is van significant verlies voor een specifiek habitattype (Ministerie van I\&W en LNV, 2018). Het deel van de Noordzee waar het verlies plaatsvindt bestaat grotendeels uit zandbodems, wat ook het habitat met het grootste oppervlak is. Het oorspronkelijk habitat wordt in alle gevallen vervangen door hard substraat (windturbines, platforms, steenstort bij kruisingen van kabels en leidingen). In de Mariene Strategie (Ministerie van I\&W en LNV, 2018) is geconcludeerd dat de GMT met betrekking tot fysiek verlies is gehaald (Ministerie van I\&W en LNV, 2018).

\section{Fysieke verstoring}

Om aan de GMT voor zeebodemintegriteit te voldoen zijn er vijf criteria voor fysieke verstoring, waarvan er drie gericht zijn op de kwaliteit van de zeebodem en twee op de intensiteit van de verstoring. De drie kwaliteitscriteria staan beschreven onder de toestand van de zeebodem (paragraaf 4.2.4). Hier wordt ingegaan op de mate van fysieke verstoring waarvoor de ICES visserijdruk indicator wordt gehanteerd (ICES, 2017). De ICES visserijdruk indicator drukt impact uit als het relatieve verlies aan benthische biomassa ten opzichte van een onverstoord systeem. Deze methode schat de impact van de bodemberoerende visserij en de resulterende staat van het benthische ecosysteem op 
basis van de Swept Area Ratio (aantal keer per jaar dat een gebied wordt bevist), de sterfte na een keer bevissen en de herstelduur van het benthos. Om te voldoen aan GMT mag de impact niet toenemen in de tijd. De impact op de zeebodem in 2015 was 0,24, enigszins vergelijkbaar met voorgaande jaren (Figuur 41). De impact varieert per habitat en is het hoogst in modderige bodems $(0,33)$ en gemengd sediment $(0,31)$ en het laagst in grof sediment $(0,26)$ en zand $(0,22)$.
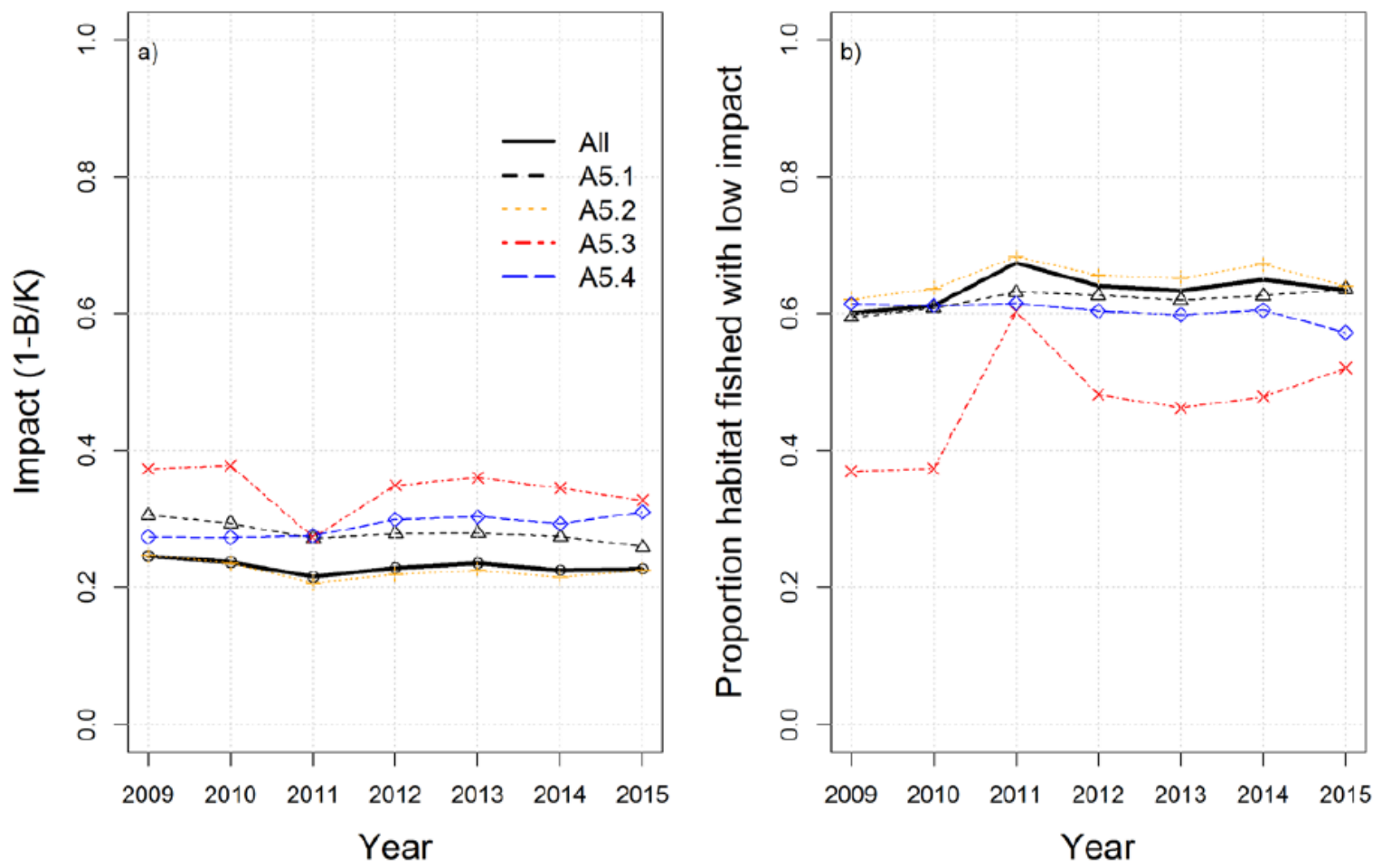

Figuur 41 ICES Indicator visserijdruk: De gemiddelde impact van 2009 tot 2015 door bodemberoerende visserij op vier EUNIS habitattypen (A5.1 -sublitoraal grof sediment, A5.2 sublitoraal zand, A5.3 -sublitoraal modder, en A5.4 - sublitoraal gemengd sediment) bij waterdieptes minder dan 200 meter in de gehele Noordzee op basis van a) de populatiedynamica methode (PD2 methode) en b) het deel van het beviste gebied met een impact van minder dan 0,2 (ICES, 2017). De waarde van 0,2 heeft geen specifieke betekenis en dient alleen ter illustratie van de benadering.

Enkele gebieden in de Internationale Noordzee hebben een lage status (zijn sterk beïnvloed), waaronder de Noorse trog, het Oost-Engelse Kanaal, de zuidelijke Noordzee, delen van de continentale kust van de Noordzee en gebieden rond de Doggersbank (Ministerie van I\&W en LNV, 2018). In CLO wordt de Indicator Intensiteit bodemvisserij uitgedrukt als het gemiddeld aantal uren per gridcel, over de periode 2011-2015. In deze periode werd de zuidelijke Noordzee door de Nederlandse visserij het meest intensief bevist door de boomkorvisserij (Figuur 42), waarbij met name de kustzone intensief is bevist. 

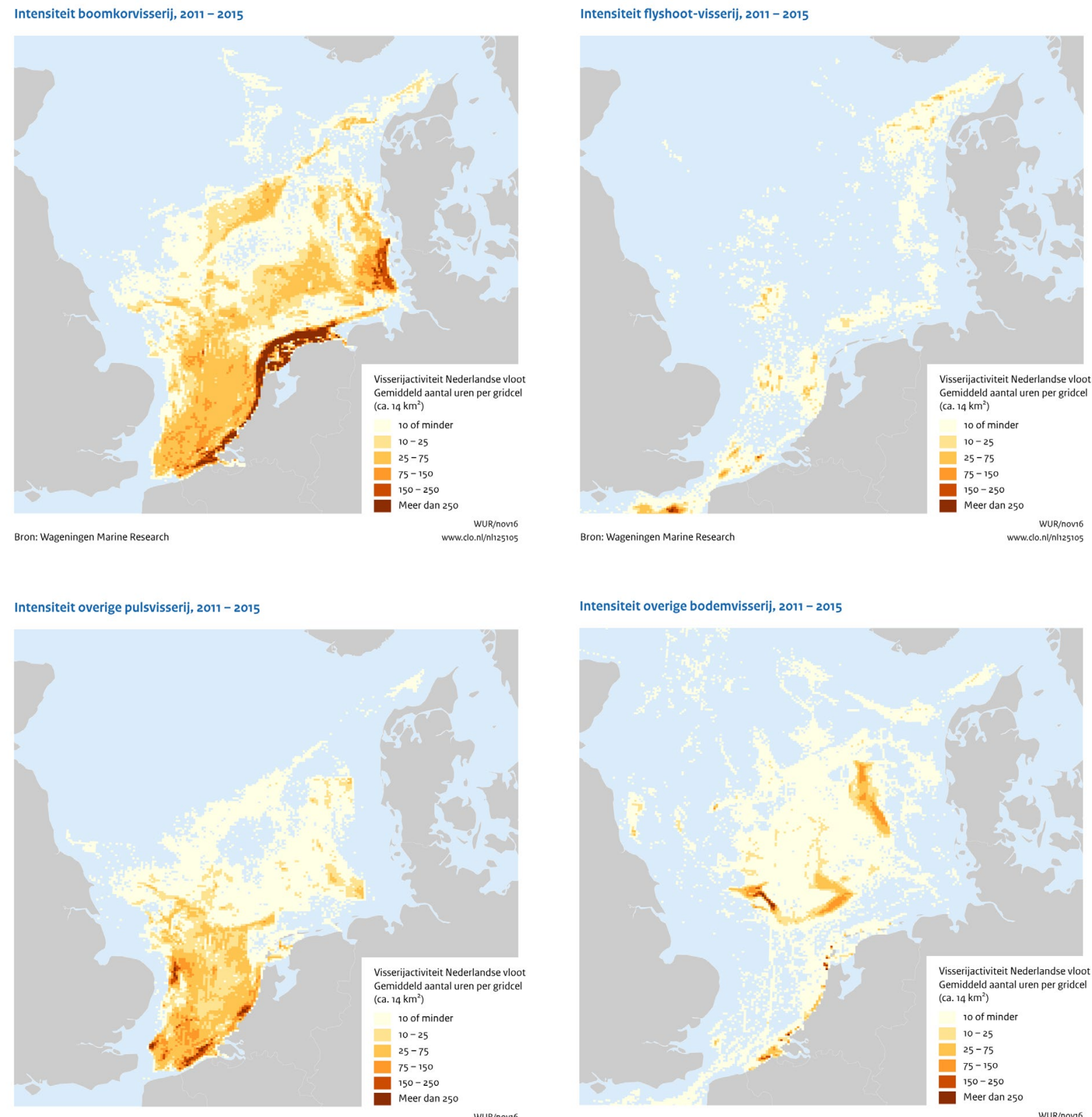

Figuur 42 CLO Indicator Intensiteit bodemvisserij: De visintensiteit door de Nederlandse visserij (gemiddeld aantal uren per gridcel) over de periode 2011-2015 voor boomkorvisserij (linksboven), flyshootvisserij (rechtsboven), overige pulsvisserij (linksonder) en overige bodemvisserij (rechtsonder) (CBS et al., 2017d).

\section{Belangrijke activiteiten en drukfactoren}

De drukfactoren die bijdragen aan het risico voor zeebodemintegriteit (verstoring en verlies van de zeebodem), geïdentificeerd aan de hand van de CEA, zijn:

- verandering van de structuur/morfologie van het habitat door o.a. bodemberoerende visserij, zandsuppletie, delfstoffenwinning;

- bodemberoering door o.a. bodemberoerende visserij, zandsuppletie en delfstoffenwinning;

- habitat verlies door o.a. windmolenparken, kustverdediging, olie- en gasactiviteiten;

- bedekking door o.a. bodemberoerende visserij, zandsuppletie, baggeren, havens.

- verkunstmatiging van habitat door o.a. kustverdediging, havens, kunstmatige riffen, landaanwinning en olie- en gasactiviteiten.

De Nederlandse KRM gaat uit van grotendeels dezelfde activiteiten (Figuur 43), waarbij de verschillende drukfactoren zijn samengevat onder de descriptor D6 'fysiek verlies en verstoring'. 


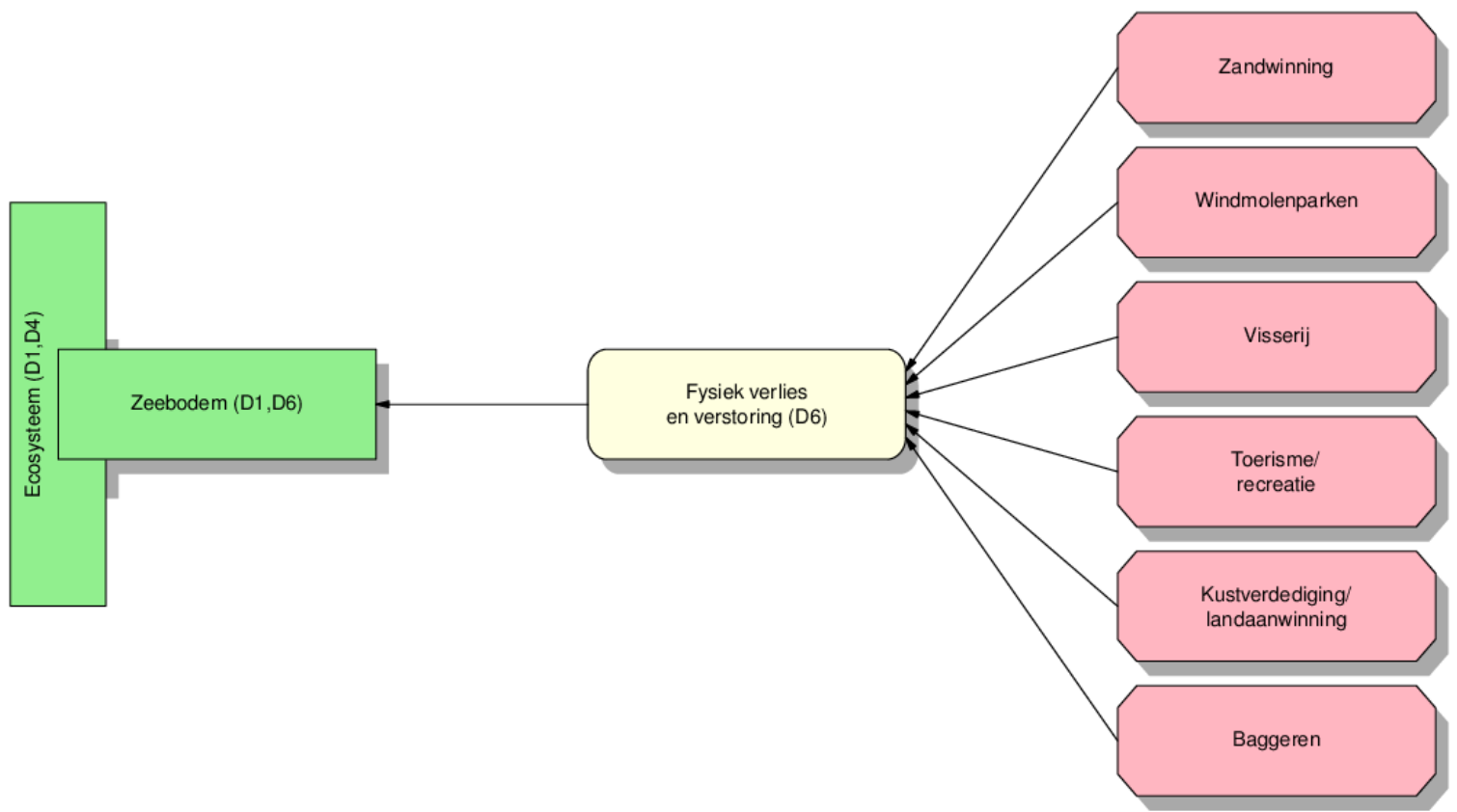

Figuur 43 De drukfactor 'fysiek verlies en verstoring', de activiteiten die daar invloed op hebben en de gerelateerde onderdelen van het Noordzee ecosysteem. De relaties zijn zoveel mogelijk gebaseerd op informatie vanuit de Nederlandse KRM (Ministerie van IenM en EZ, 2014; Ministerie van I\&W en LNV, 2018). D1 Biodiversiteit; D2 Niet-inheemse soorten; D3 Commerciële visbestanden; D4 Voedselweb; D5 Eutrofiering; D6 Bodemintegriteit; D7 Hydrografische eigenschappen; D8 Vervuilende stoffen; D9 Vervuilende stoffen in vis; D10 Zwerfvuil; D11 Energietoevoer, o.m. onderwatergeluid.

De verschillende gebruiksfuncties op de Nederlandse Noordzee gebruiken allemaal een bepaald deel van de ruimte op zee (Tabel 18). Dit ruimtegebruik is inclusief de veiligheidszones rondom een gebruiksfunctie (bijvoorbeeld $500 \mathrm{~m}$ rondom een platform) en is dus geen weergave van het oppervlak dat daadwerkelijk fysiek wordt ingenomen. De grootste bijdrage aan het fysiek verlies is in de afgelopen periode veroorzaakt door olie- en gaswinningsactiviteiten (Tabel 19). De belangrijkste activiteiten die in Nederlandse mariene wateren fysiek verlies tot gevolg kunnen hebben zijn landaanwinning, de aanleg van platforms voor olie- en gaswinning en de aanleg van nieuwe windparken (Ministerie van I\&W en LNV, 2018). Landaanwinning heeft sinds 2012 geen fysiek verlies veroorzaakt. De tweede Maasvlakte, met een oppervlakte van $20 \mathrm{~km}^{2}$, is tussen 2008 en 2013 gebouwd en in gebruik genomen en is in zijn geheel toegeschreven aan de periode voor 2012 (Ministerie van I\&W en LNV, 2018). Voor platforms voor olie- en gaswinning is uitgegaan van een verlies van 100 meter rondom een platform voor standaard productieplatforms en $50 \mathrm{~m}$ voor subsea completion (Tabel 19). Kabels en leidingen worden over het algemeen ingegraven en veroorzaken dus geen verlies, alleen bij kruisingen met andere kabels en leidingen wordt een steenbestorting toegepast. Daarvoor is uitgegaan van een oppervlakte van $500 \mathrm{~m}^{2}$ per kruising. Het totaal verlies aan natuurlijke zeebodem sinds 2012 is $0,55 \mathrm{~km}^{2}$, dit is $0,001 \%$ van de totale Nederlandse Noordzee $\left(58.000 \mathrm{~km}^{2}\right)$, zoals eerder vermeld onder de huidige toestand en trend. 
Tabel 18 Ruimtebeslag van gebruiksfuncties op de Nederlandse (Ministerie van I\&W en LNV, 2018)

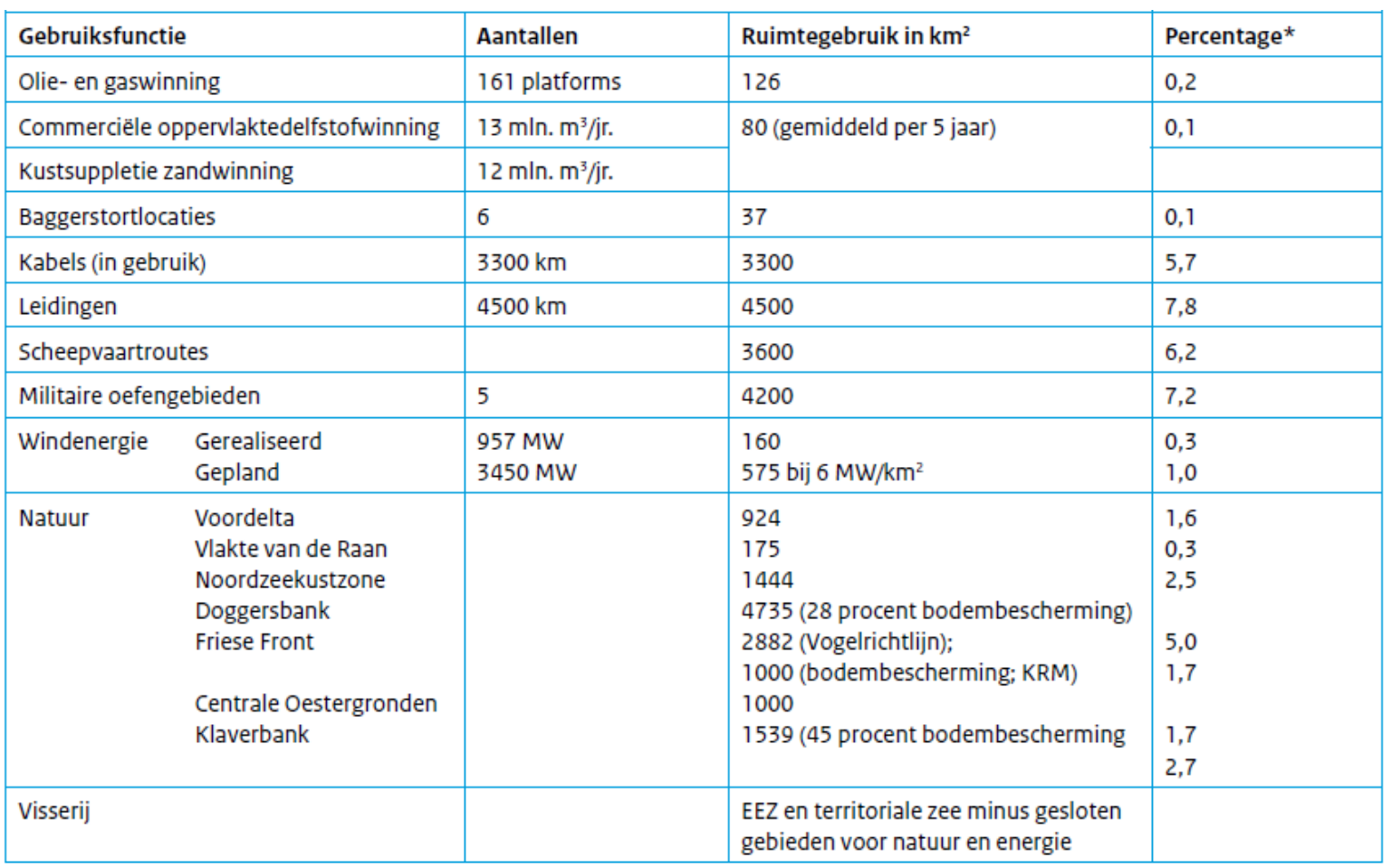

* percentage van het $\mathrm{NCP}\left(58.000 \mathrm{~km}^{2}\right)$

Tabel 19 Fysiek verlies van de natuurlijke zeebodem in de Nederlandse Noordzee sinds het referentiejaar 2012 (Ministerie van I\&W en LNV, 2018)

\begin{tabular}{|c|c|c|c|c|}
\hline Activiteit & Aantal & Fysiek verlies & $\begin{array}{l}\text { Verlies } \\
\text { per stuk }\end{array}$ & $\begin{array}{l}\text { Totaal } \\
\text { verlies }\end{array}$ \\
\hline \multicolumn{5}{|l|}{ Windparken } \\
\hline Luchterduinen & 43 turbinepalen & $12,5 \mathrm{~m}$ rondom paal & $491 \mathrm{~m}^{2}$ & $0,02 \mathrm{~km}^{2}$ \\
\hline Gemini & 150 turbinepalen & 15 m rondom paal & $706,5 \mathrm{~m}^{2}$ & $0,11 \mathrm{~km}^{2}$ \\
\hline \multicolumn{5}{|l|}{ Olie- en gasactiviteiten } \\
\hline Platform voor olie- en gaswinning & 12 platforms & $100 \mathrm{~m}$ rondom platform & $0,03 \mathrm{~km}^{2}$ & $0,38 \mathrm{~km}^{2}$ \\
\hline Subsea completion & 5 platforms & $50 \mathrm{~m}$ rondom platform & $0,01 \mathrm{~km}^{2}$ & $0,04 \mathrm{~km}^{2}$ \\
\hline \multicolumn{5}{|l|}{ Kabels en leidingen } \\
\hline Kruisingen van kabels en leidingen & 20 kruisingen & $5 \mathrm{~m} \times 100 \mathrm{~m}$ & $500 \mathrm{~m}^{2}$ & $0,01 \mathrm{~km}^{2}$ \\
\hline \multicolumn{5}{|l|}{ Landaanwinning } \\
\hline Geen ( $2^{\text {de }}$ Maasvlakte is in periode voor 2012 ) & - & - & - & - \\
\hline Totaal & & & & $0,55 \mathrm{~km}^{2}$ \\
\hline
\end{tabular}

Fysieke verstoring wordt veroorzaakt door bodemberoerende visserij. Boomkorvisserij op tong en schol veroorzaakt het meeste verstoring van de ondergrond terwijl de meeste verstoring op het bodemoppervlak wordt veroorzaakt door flyshootvisserij (Figuur 44).

Zandwinning wordt nu nog beoordeeld als een activiteit die fysieke verstoring veroorzaakt en valt daarmee in het niet vergeleken met de effecten van visserij. Er is echter volop discussie over de criteria waarop het onderscheid tussen fysieke verstoring en fysiek verlies gebaseerd is. Dit kan er toe leiden dat zandwinning (zeker als de vraag verder toeneemt) voortaan gezien kan worden als een veroorzaker van fysiek verlies. Dit resulteert dan weer in een relatief grote toename van het totaal verlies aan zeebodem. 


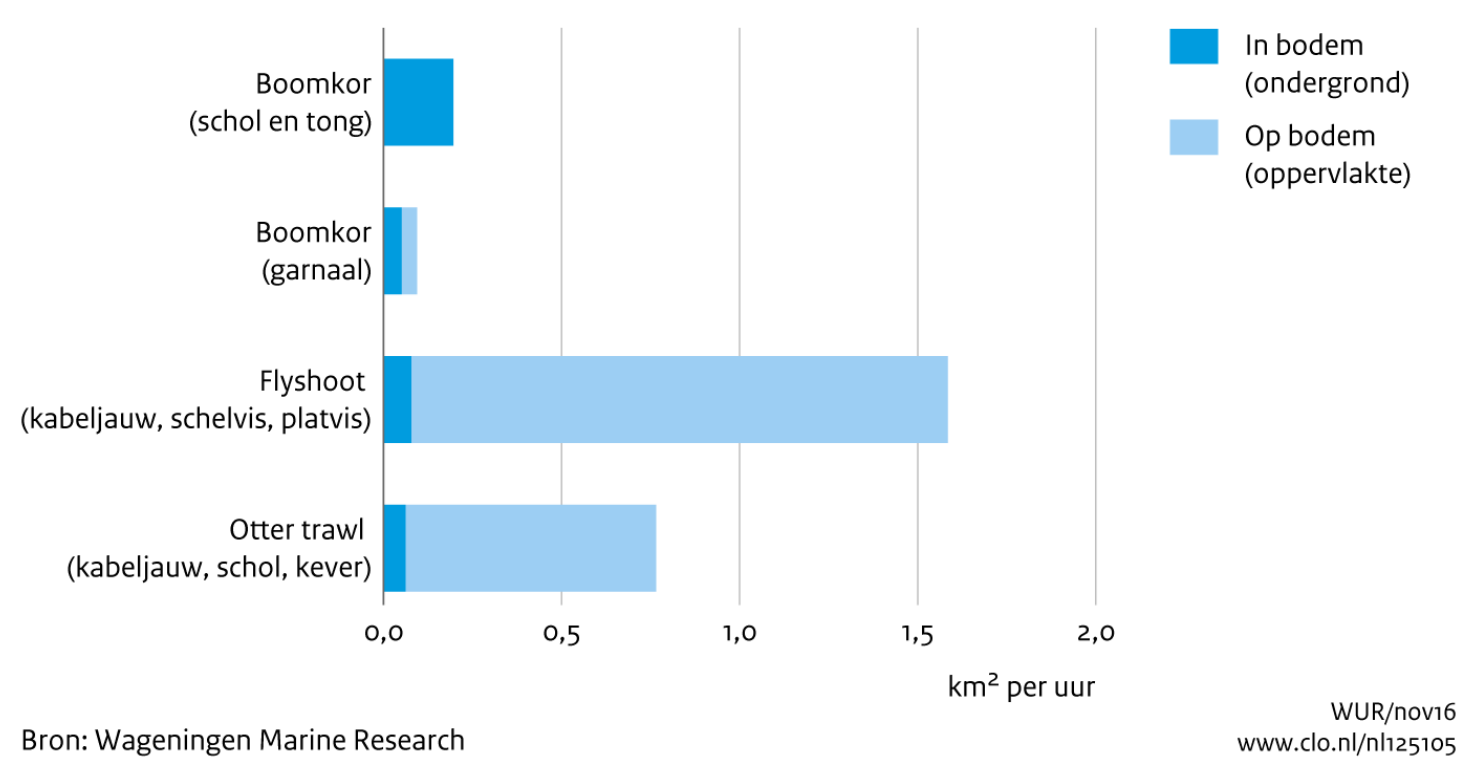

Figuur 44 De fysieke verstoring van de ondergrond en oppervlakte van de zeebodem door verschillende bodemvisserijtypen (CBS et al., 2017d).

\section{Milieudoelen en beleidsmaatregelen}

De milieudoelen om de voortgang tot GMT voor zeebodemintegriteit te begeleiden zijn (Ministerie van I\&W en LNV, 2018):

- D6T1: 10-15 procent van het oppervlak van het Nederlandse deel van de Noordzee wordt niet noemenswaardig beroerd door menselijke activiteiten.

- D6T3: geen toename in de fysieke verstoring door visserijactiviteiten in de tijd op de totale zeebodem van het NCP en op de habitats die in het kader van de KRM zijn beschreven.

- D1T3: realiseren instandhoudingsdoelstellingen voor habitattypen en soorten in de Natura 2000-gebieden op zee (VHR).

De selectie van maatregelen uit het programma van maatregelen (2015), zoals aangegeven door het Ministerie van I\&W en LNV (2018):

- Voor wat betreft fysiek verlies worden er voorwaarden gesteld aan vergunningverlening;

- $\quad$ Specifiek voor de Noordzeekustzone is op 31 mei 2017 een nieuw Noordzeekustvisserijakkoord (VIBEG-2) gesloten voor de periode 2017-2026;

- Zie de maatregelen in paragraaf 4.2.4 (zeebodem).

In de Mariene Strategie (Ministerie van I\&W en LNV, 2018) wordt aangenomen dat het bestaand beleid voldoet om de GMT voor zeebodemintegriteit te behalen. Wel bestaat er een kennisopgave met betrekking tot cumulatie.

\subsubsection{Hydrografische eigenschappen}

\section{Huidige toestand en trend}

Met de descriptor hydrografische eigenschappen wordt de toestand van de zeebodemligging, stromingen en golven beoordeeld. Veranderingen in hydrografische eigenschappen hebben invloed op fysische en chemische eigenschappen van de zee, bijvoorbeeld de bodemschuifspanning, het sedimenttransport, de saliniteit of de watertemperatuur. Dergelijke invloeden op mariene ecosystemen kunnen relevant zijn wanneer zij zich op grotere schaal voordoen en een permanent 
karakter hebben. De mariene habitats kunnen daardoor veranderen of geheel verdwijnen (Ministerie van I\&W en LNV, 2018).

De GMT voor deze descriptor is als volgt beschreven: Het mariene ecosysteem ondervindt geen negatieve effecten als gevolg van permanente wijzigingen in de hydrografische eigenschappen als gevolg van menselijke activiteiten. Deze GMT is gehaald in 2012 en behouden (Tabel 20; Ministerie van I\&W en LNV, 2018). Hierbij wordt aangegeven dat grootschalige hydrografische ingrepen uit het verleden (zoals de Deltawerken en de Maasvlakte I) als onomkeerbaar worden beschouwd en dat er de afgelopen periode geen nieuwe grootschalige ingrepen zijn geweest.

Aangezien de GMT voor deze descriptor bereikt is, zijn er in de Nederlandse implementatie van de KRM op criterium niveau geen GMT en doelen geformuleerd. Op Europees niveau zijn voor hydrografische eigenschappen de volgende (niet verplicht op te nemen) criteria aangegeven (EC, 2017):

- $\quad$ D7C1: De ruimtelijke omvang en spreiding van de permanente wijziging van de hydrografische omstandigheden (bv. wijzigingen van de golfslag, de stroming, het zoutgehalte, de temperatuur) van de zeebodem en de waterkolom, vooral in verband met het fysieke verlies van de natuurlijke zeebodem;

- D7C2: De ruimtelijke omvang van elk benthisch habitattype dat schade is berokkend (de fysieke en hydrografische kenmerken en de bijbehorende biologische gemeenschappen) door permanente wijziging van de hydrografische omstandigheden.

De KRM doelstelling voor hydrografische eigenschappen is gehaald.

Tabel 20 Toestandsbeoordeling KRM descriptor 7, hydrografische omstandigheden (gebaseerd op Ministerie van I\&W en LNV, 2018). De status geeft aan of de goede milieutoestand is gehaald (goed), niet gehaald (niet goed), nog niet bekend is vanwege bijvoorbeeld het ontbreken van vastgestelde grenswaarden/streefwaarden (onbekend).

\begin{tabular}{|l|l|l|l|}
\hline Criteria & Goede milieutoestand* & Indicator \\
\hline D7C1 & Het mariene ecosysteem ondervindt geen negatieve effecten & Geen & Goed \\
\cline { 4 - 4 } D7C2 & $\begin{array}{l}\text { als gevolg van permanente wijzigingen in de hydrografische } \\
\text { eigenschappen als gevolg van menselijke activiteiten. }\end{array}$ & Geen \\
\hline
\end{tabular}

* Op het niveau van de descriptor niveau en niet op criteria en/of indicator niveau

\section{Belangrijke activiteiten en drukfactoren}

De belangrijkste drukfactoren en activiteiten die bijdragen aan het risico voor hydrografische eigenschappen die geïdentificeerd zijn door gebruik te maken van de CEA zijn:

- verandering van de structuur/morfologie van het habitat door o.a. bodemberoerende visserij, zandsuppletie, delfstoffenwinning;

- verandering in golfslag en getij door o.a. getijdensluizen, kustverdediging, landaanwinning, zandsuppletie en havens;

- verandering van waterstroming door o.a. getijdensluizen, havens, kustverdediging, landaanwinning en baggeren;

- $\quad$ verkunstmatiging van habitat door o.a. kustverdediging, havens, kunstmatige riffen en landaanwinning.

De Nederlandse KRM gaat uit van slechts drie activiteiten (Figuur 45), waarbij de verschillende drukfactoren zijn samengevat onder de descriptor D7 'hydrografische eigenschappen'.

Aangezien de GMT is bereikt voor deze descriptor (zie hierboven) zijn deze bijdragen aan het huidige risico niet zo zeer van belang. Echter, voor de toekomst spelen deze activiteiten wel een rol vanwege de grootschalige ontwikkeling van windenergie op zee, zandwinning en kustverdediging, zie ook de rapportage NatuurVerkenning Noordzee (Jongbloed et al., in prep.). Deze activiteiten behoren namelijk tot de activiteiten die het meest bijdragen aan het risico voor hydrografische eigenschappen. In het beleid wordt rekening gehouden met mogelijke effecten van grootschalige ingrepen, zie beleidsmaatregelen hieronder. 


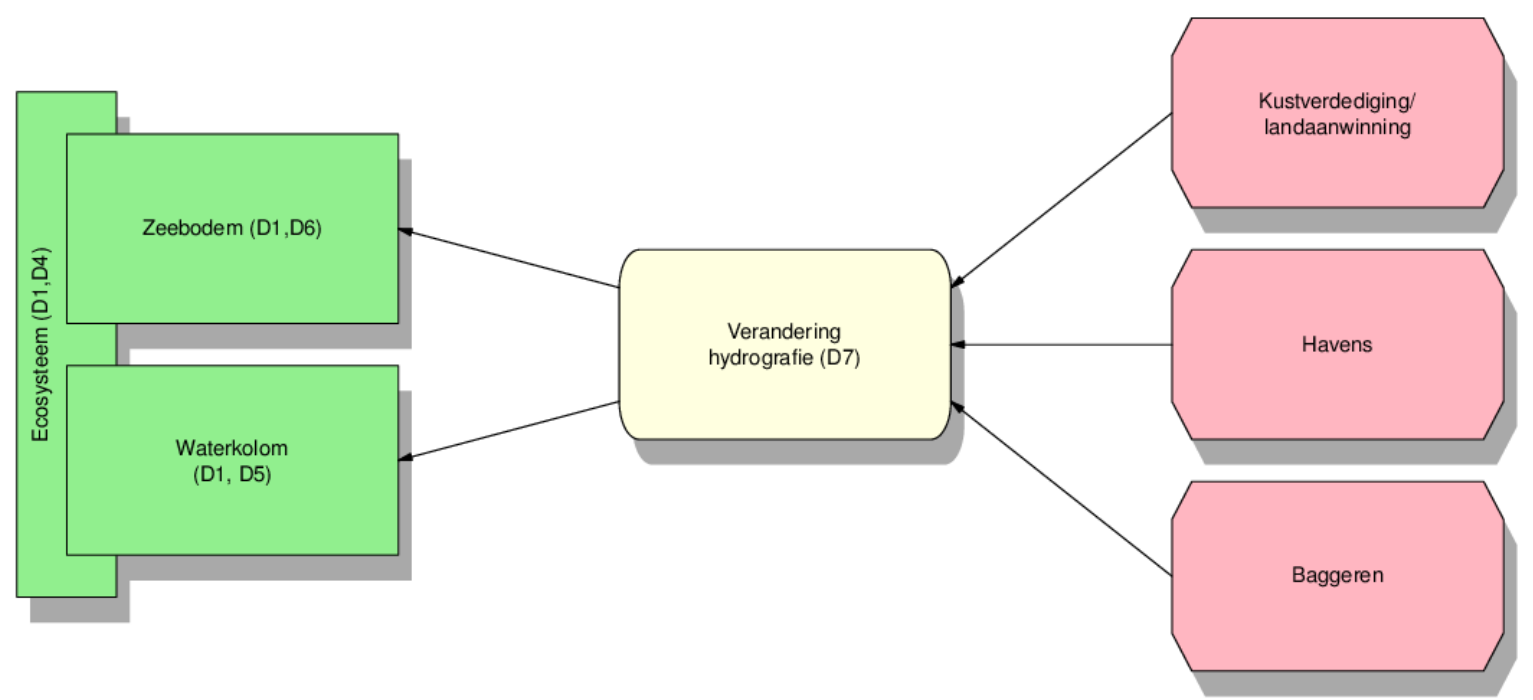

Figuur 45 De drukfactor 'verandering hydrografie', de activiteiten die daar invloed op hebben en de gerelateerde onderdelen van het Noordzee ecosysteem. De relaties zijn zoveel mogelijk gebaseerd op informatie vanuit de Nederlandse KRM (Ministerie van IenM en EZ, 2014; Ministerie van I\&W en LNV, 2018). D1 Biodiversiteit; D2 Niet-inheemse soorten; D3 Commerciële visbestanden; D4 Voedselweb; D5 Eutrofiering; D6 Bodemintegriteit; D7 Hydrografische eigenschappen; D8 Vervuilende stoffen; D9 Vervuilende stoffen in vis; D10 Zwerfvuil; D11 Energietoevoer, o.m. onderwatergeluid.

\section{Milieudoelen en beleidsmaatregelen}

De milieudoelen om de voortgang tot GMT voor hydrografische omstandigheden te begeleiden zijn (Ministerie van I\&W en LNV, 2018):

- D7T1: alle ontwikkelingen moeten voldoen aan de eisen van het bestaande wettelijke regime (bijvoorbeeld de Wet milieubeheer en de Wet natuurbescherming) en wettelijke beoordelingen moeten op zo'n wijze worden uitgevoerd, dat potentiële effecten van permanente wijzigingen in hydrografische eigenschappen, met inbegrip van cumulatieve effecten, in de beschouwing worden betrokken op het meest geëigende ruimtelijke schaalniveau op grond van de richtsnoeren die hiervoor zijn ontwikkeld (EUNIS-niveau 3, referentiejaar 2012).

De selectie van maatregelen uit het programma van maatregelen (2015), zoals aangegeven door het Ministerie van I\&W en LNV (2018):

- Beoordeling hydrografische ingrepen en compensatie ongewenste effecten.

In de Mariene Strategie (Ministerie van I\&W en LNV, 2018) is geconcludeerd dat het bestaand beleid voldoet om de GMT voor hydrografische omstandigheden te behalen. Wel is er een kennisopgave met betrekking tot de cumulatieve effecten van windenergie op zee, zandwinning en zandsuppletie (Ministerie van I\&W en LNV, 2018).

\subsubsection{Vervuilende stoffen}

\section{Huidige toestand en trend}

De KRM doelstelling voor vervuilende stoffen: "De concentraties van voor het mariene milieu relevante vervuilende stoffen, gemeten in het meest geëigende compartiment (water, sediment of biota), zijn lager dan de concentraties waarbij negatieve effecten kunnen optreden of laten een dalende trend zien", is nog niet gehaald (Tabel 21). Voor deze descriptor is een KRM Artikel 14 uitzondering gerapporteerd (Ministerie van I\&W en LNV, 2018), zie ook D5 eutrofiëring. Daarbij is gerapporteerd dat het KRM programma van maatregelen de maximale inzet geeft die mogelijk is om voor de descriptor gevaarlijke stoffen de goede milieutoestand te bereiken, zowel voor maatregelen op land (uitvoering KRW) als voor maatregelen op zee. Er zijn geen technische maatregelen mogelijk die 
aanwezigheid van gevaarlijke stoffen in het Nederlandse deel van de Noordzee teniet kunnen doen. Natuurlijke omstandigheden laten niet toe dat de toestand van dit deel van de Noordzee tijdig verbeterd (Ministerie van I\&W en LNV, 2018).

De KRM doelstelling voor vervuilende stoffen in vis(producten) is echter wel gehaald (Tabel 21).

In de beoordeling voor de KRM (Ministerie van I\&W en LNV, 2018) wordt geconcludeerd dat als gevolg van bestaand beleid de milieurisico's van ongewenste vervuilingseffecten op het mariene milieu verder zullen dalen en tussen 2020 en 2027 of daarna zelfs klein zijn. Daarmee zal naar verwachting in de jaren na 2020 de goede milieutoestand voor de meeste stoffen binnen handbereik liggen (Ministerie van I\&W en LNV, 2018).

Tabel 21 Toestandsbeoordeling KRM descriptor 8, vervuilende stoffen (gebaseerd op Ministerie van I\&W en LNV, 2018). De status geeft aan of de goede milieutoestand is gehaald (goed), niet gehaald (niet goed), nog niet bekend is vanwege bijvoorbeeld het ontbreken van vastgestelde grenswaarden/streefwaarden (onbekend).

\begin{tabular}{|c|c|c|c|}
\hline Criteria & Goede milieutoestand & Indicator & Status \\
\hline & \multicolumn{3}{|l|}{ Kustwateren } \\
\hline $\mathrm{D} 8 \mathrm{C} 1$ & $\begin{array}{l}\text { De concentraties van voor het mariene milieu relevante } \\
\text { vervuilende stoffen, gemeten in het meest geëigende } \\
\text { compartiment (water of biota) voldoen aan de Environmental } \\
\text { Quality Standards die bij de KRW worden gebruikt in de 12- } \\
\text { mijls zone (voor prioritaire stoffen) respectievelijk in de 1- } \\
\text { mijlszone (voor alle overige stoffen). }\end{array}$ & $\begin{array}{l}\mathrm{NL}-\mathrm{KRW} \text { specifiek } \\
\text { verontreinigende stoffen in } \\
\text { de } 1 \text {-mijlszone en prioritaire } \\
\text { stoffen in de } 12 \text {-mijlszone. }\end{array}$ & Onbekend \\
\hline & \multicolumn{3}{|l|}{ Offshore wateren } \\
\hline \multirow[t]{9}{*}{ D8C1 } & \multirow{9}{*}{$\begin{array}{l}\text { De concentraties van voor het mariene milieu relevante } \\
\text { vervuilende stoffen, gemeten in het meest geëigende } \\
\text { compartiment (sediment of biota) voldoen aan de milieu- } \\
\text { evaluatiecriteria (Environmental Assessment Criteria, EAC) } \\
\text { en/of achtergrondevaluatiecriteria (Background Assessment } \\
\text { Criteria, BAC) van OSPAR, of ze laten, waar deze } \\
\text { streefwaarden nog niet zijn geformuleerd, een dalende trend } \\
\text { zien (conform OSPAR). }\end{array}$} & OSPAR - PAK's in biota & Onbekend \\
\hline & & OSPAR - PAK's in sediment & Niet goed \\
\hline & & OSPAR - PCB's in biota & Goed \\
\hline & & OSPAR - PCB's in sediment & Goed \\
\hline & & OSPAR - PBDE's in biota & Niet goed \\
\hline & & OSPAR - PBDE's in sediment & Onbekend \\
\hline & & $\begin{array}{l}\text { OSPAR - organotin in } \\
\text { sediment }\end{array}$ & Goed \\
\hline & & OSPAR - metalen in biota & Niet goed \\
\hline & & OSPAR - metalen in sediment & Goed \\
\hline & \multicolumn{3}{|l|}{ Overkoepelend } \\
\hline \multirow[t]{2}{*}{ D8C1 } & \multirow{2}{*}{$\begin{array}{l}\text { De concentraties van voor het mariene milieu relevante } \\
\text { vervuilende stoffen, gemeten in het meest geëigende } \\
\text { compartiment (sediment of biota) voldoen aan de milieu- } \\
\text { evaluatiecriteria (Environmental Assessment Criteria, EAC) } \\
\text { en/of achtergrondevaluatiecriteria (Background Assessment } \\
\text { Criteria, BAC) van OSPAR, of ze laten, waar deze } \\
\text { streefwaarden nog niet zijn geformuleerd, een dalende trend } \\
\text { zien (conform OSPAR). }\end{array}$} & $\begin{array}{l}\text { OSPAR - Bronnen van zware } \\
\text { metalen }\end{array}$ & Onbekend \\
\hline & & NL-koperconcentraties* & Onbekend \\
\hline D8C2 & Dalende trend ten opzichte van 2012 van Imposex. & OSPAR D8C2 Imposex & Onbekend \\
\hline D8C3 & $\begin{array}{l}\text { De ruimtelijke omvang en de duur van de significante ernstige } \\
\text { verontreinigingen zijn tot een minimum beperkt. }\end{array}$ & $\begin{array}{l}\text { Acute verontreinigingen: } \\
\text { aantal olielozingen en het } \\
\text { volume per incident (Bonn } \\
\text { Agreement). }\end{array}$ & Niet goed \\
\hline \multicolumn{4}{|c|}{ Gevaarlijke stoffen in vis } \\
\hline D9C1 & $\begin{array}{l}\text { De niveaus van vervuilende stoffen (waaronder PAK's, dioxinen } \\
\text { en zware metalen) in vis en visproducten uit de Noordzee } \\
\text { overschrijden de in de EU verordening EG } 1881 / 2006 \\
\text { vastgestelde maximumgehalten niet. }\end{array}$ & $\begin{array}{l}\text { NL - Beoordeling volgens } \\
\text { EG1881/2006 }\end{array}$ & Goed \\
\hline
\end{tabular}

* koperconcentraties zijn nog niet opgenomen in het KRMmonitoringprogramma. Naar verwachting zal dit uiterlijk in 2020 gebeuren.

De criteria zijn gerelateerd aan de KRW, OSPAR, Bonn overeenkomst (acute verontreiniging) en vervuilende stoffen in vis. Deze worden hieronder kort toegelicht.

\section{Kaderrichtlijn Water (KRW)}

Volgens de prognoses worden de KRW-doelen op termijn gerealiseerd (Ministerie van I\&W en LNV, 2018). Dit geldt echter niet voor stoffen waarvan de productie of het gebruik al is verboden, maar die vanwege persistentie nog lang in het milieu zullen voorkomen, de zogenaamde ubiquitaire stoffen (Tabel 22).

Volgens de KRW-beoordeling overschrijdt kwik de EU-norm in water in het KRW-waterlichaam EemsDollard kustwater. Tributyltin overschrijdt de KRW EU-norm in water in de KRW waterlichamen Hollandse kust, Noordelijke Deltakust en Zeeuwse kust. Benzo[g,h,i]peryleen overschrijdt de KRW EUnorm in water in de KRW waterlichamen Hollandse kust, Noordelijke Deltakust, Zeeuwse kust, Waddenkust en Eems-Dollard kustwater. Analyse van kwik op normniveau is nog niet mogelijk (de rapportagegrens van kwik ligt boven de norm in water), daarom kan nog niet bepaald worden of alle wateren aan norm voldoen (Ministerie van I\&W en LNV, 2018). 
Tabel 22 KRW beoordeling chemie voor de kustwateren (Eems-Dollard; Hollandse kust; Noordelijke Deltakust; Waddenkust; Zeeuwse kust). Onder ubiquitaire stoffen wordt verstaan: stoffen waarvan de productie of het gebruik al is verboden, maar die vanwege persistentie nog lang in het milieu zullen voorkomen (Rijkswaterstaat, 2016).

\begin{tabular}{|c|c|c|c|c|c|c|}
\hline \multicolumn{2}{|c|}{ Eindoordeel } & $\begin{array}{c}\text { Toestand } \\
2009\end{array}$ & $\begin{array}{c}\text { Toestand } \\
2015\end{array}$ & $\begin{array}{c}\text { Toestand } \\
2016\end{array}$ & $\begin{array}{c}\text { Prognose } \\
2021\end{array}$ & $\begin{array}{c}\text { Prognose } \\
2027\end{array}$ \\
\hline \multirow[t]{3}{*}{ Chemie } & Chemie totaal & * & * & & & \\
\hline & Ubiquitaire stoffen & & & & & \\
\hline & Niet-Ubiquitaire stoffen & & * & & & \\
\hline \multicolumn{7}{|l|}{ Legenda: } \\
\hline - Chemie: & blauw = goed / voldoet & $\mathrm{d}=$ niet go & d / voldoet & niet & & \\
\hline
\end{tabular}

OSPAR

Concentraties van relevante vervuilende stoffen zijn over het algemeen onder niveaus waarbij effecten worden verwacht, zijn deze voor de meeste stoffen nog niet gedaald tot achtergrondniveau (OSPAR, 2017). Voor PAK's bijvoorbeeld, ligt de gemiddelde concentratie in schaal- en schelpdieren in alle beoordeelde OSPAR-subregio's boven de achtergrondwaarden maar onder de OSPAR milieuevaluatiecriteria beoordelingscriteria. Daarom mag worden aangenomen dat zij geen nadelige effecten Veroorzaken (OSPAR, 2017). Voor de Zuidelijke Noordzee is de trend stabiel (Ministerie van I\&W en LNV, 2018). Om de GMT te bereiken is een dalende trend nodig. De KRM D8C1 status voor PAK in biota is als onbekend gerapporteerd (Ministerie van I\&W en LNV, 2018).

De OSPAR indicator 'bronnen van zware metalen' is als KRM indicator voor D8 opgenomen maar er is in het KRM rapport (Ministerie van I\&W en LNV, 2018) niets gerapporteerd over de toestand van deze indicator. OSPAR geeft aan dat de OSPAR landen maatregelen hebben genomen om emissies van zware metalen naar zowel de lucht als water te reduceren wat voor de reductie van atmosferische input van lood naar de Noordzee het meest succesvol is geweest (Figuur 46). Hierbij wordt opgemerkt dat er grote onzekerheid bestaat in de schattingen van de input van zware metalen naar de Noordzee.

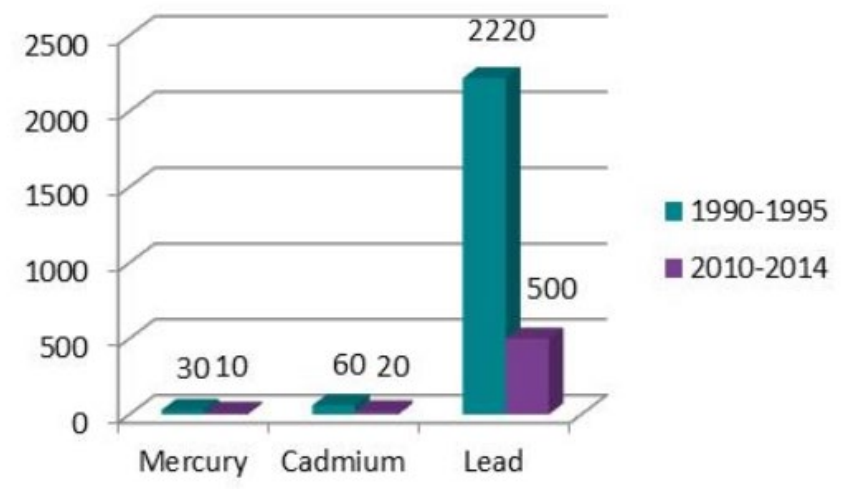

Figuur 46 Geschatte totale input (via rivieren en atmosfeer) van kwik (mercury), cadmium en lood (lead) naar de totale Noordzee in 1990-1995 en 2010-2014. Waarden zijn uitgedrukt in tonnen, afgerond tot 5 ton en voor lood afgerond tot 100 ton (OSPAR, 2017).

\section{Bonn Overeenkomst}

Acute verontreinigingen worden gemonitord binnen de Bonn Overeenkomst. De Bonn Overeenkomst regelt de samenwerking van de kuststaten van de Noordzee bij de opsporing, melding en bestrijding van verontreiniging van de Noordzee door olie en andere schadelijke stoffen. Het betreft hierbij dergelijke vervuiling afkomstig van schepen en installaties. De goede milieutoestand is pas behaald als er geen moedwillige of calamiteuze verontreinigingen meer zijn. Ondanks de sterke daling in de 
periode sinds 2000 is het aantal verontreinigingen niet nul (Ministerie van I\&W en LNV, 2018). Het criterium is dan ook nog niet bereikt.

Gevaarlijke stoffen in vis

De gehalten van dioxine-TEQ, som-TEQ, ndl-PCB's, cadmium, lood en kwik zijn onderzocht in monsters visserijproducten uit de Noordzee. De gehalten liggen in alle onderzochte monsters ruim onder de betreffende maximumgehalten, waarmee een goede milieutoestand is bereikt. $\mathrm{Bij}$ ongewijzigd beleid zal Nederland in 2020 en daarna deze toestand kunnen vasthouden (Ministerie van I\&W en LNV, 2018).

\section{Belangrijke activiteiten en drukfactoren}

Er zijn drie drukfactoren opgenomen in de huidige CEA die bijdragen aan het risico van vervuilende stoffen: introductie van niet-synthetische stoffen (metalen en koolwaterstoffen), radionucliden en synthetische stoffen. De belangrijkste activiteiten die daaraan bijdragen zijn scheepvaart, havens, activiteiten op land (waterzuivering, industrie en energiecentrales), toerisme en recreatie, militaire operaties, olie- en gasactiviteiten en delfstoffenwinning. Bij de Nederlandse KRM wordt uitgegaan van grotendeels dezelfde activiteiten (Figuur 47).

De toestand met betrekking tot niet-synthetische stoffen is voor sommige stofgroepen nog niet goed (PAK's in sediment en metalen in biota). Alleen metalen in biota voldoen aan het criterium. De toestand met betrekking tot synthetische stoffen is niet goed voor wat betreft PBDE's in biota. Voor PCB's in biota en sediment en voor organotin in sediment is de toestand wel voldoende.

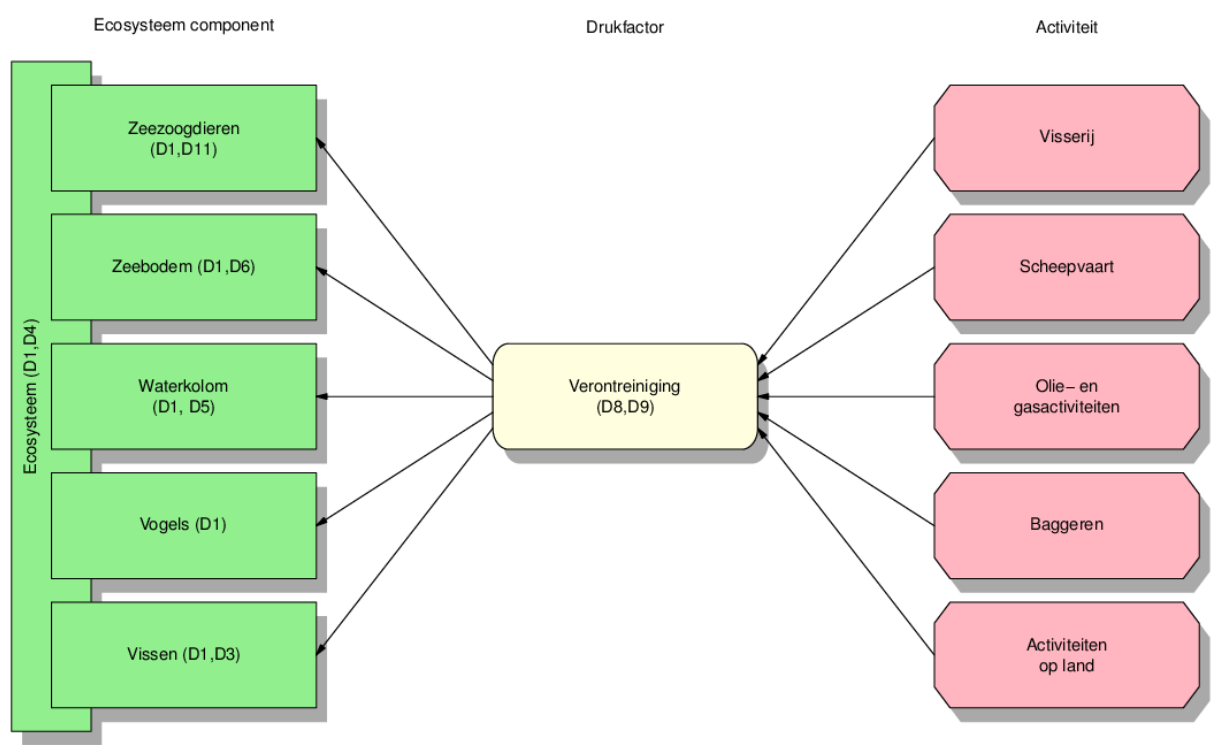

Figuur 47 De drukfactor 'vervuilende stoffen', de activiteiten die daar invloed op hebben en de gerelateerde onderdelen van het Noordzee ecosysteem. De relaties zijn zoveel mogelijk gebaseerd op informatie vanuit de Nederlandse KRM (Ministerie van IenM en EZ, 2014; Ministerie van I\&W en LNV, 2018). D1 Biodiversiteit; D2 Niet-inheemse soorten; D3 Commerciële visbestanden; D4 Voedselweb; D5 Eutrofiering; D6 Bodemintegriteit; D7 Hydrografische eigenschappen; D8 Vervuilende stoffen; D9 Vervuilende stoffen in vis; D10 Zwerfvuil; D11 Energietoevoer, o.m. onderwatergeluid.

\section{Milieudoelen en beleidsmaatregelen}

De milieudoelen om de voortgang tot GMT voor vervuilende stoffen te begeleiden zijn (Ministerie van I\&W en LNV, 2018):

- D8T1 (kustwateren): het verlagen van de toevoer van vervuilende stoffen die nog niet aan de KRW-normen voldoen, conform het tijdpad van de stroomgebied-beheerplannen.

Concentraties van vervuilende stoffen die al voldoen aan de KRW-normen niet laten toenemen;

- D8T2 (offshore): waar mogelijk verlagen van concentraties van vervuilende stoffen;

- D8T4: verlagen van de toevoer van zware metalen in het mariene milieu; 
- $\quad$ D8T3: het op regionaal niveau volgen van koperconcentraties, nu dit zware metaal wordt ingezet als vervanger voor TBT (OSPAR);

- $\quad$ D8T5: het zo snel mogelijk opruimen van acute ernstige verontreinigingen, waar nodig in samenwerking binnen de Bonn Agreement;

- D8T6: verminderen van gebruik lood, onder andere in de sportvisserij (KRW).

- D9T1: de gehalten van vervuilende stoffen in vis en visproducten die voldoen aan nationale en internationale wetgeving, niet laten toenemen en zo mogelijk verder verlagen.

De selectie van maatregelen uit het programma van maatregelen (2015), zoals aangegeven door het Ministerie van I\&W en LNV (2018):

- uitvoering maatregelen op grond van KRW met betrekking tot industriële emissies, gewasbestrijdingsmiddelen en lozingen binnenvaart;

- $\quad$ beperking lozing door incidenten en rampen;

- $\quad$ beperking lozing olie- en gasproductie (OSPAR);

- beperking lozingen scheepvaart (MARPOL) en;

- $\quad$ verbod TBT.

Voor wat betreft gevaarlijke stoffen in vis en visproducten zijn geen maatregelen noodzakelijk en geldt alleen de wettelijke normering (Ministerie van I\&W en LNV, 2018).

In de Mariene Strategie (Ministerie van I\&W en LNV, 2018) is geconcludeerd dat het bestaand beleid voldoet om de GMT voor vervuilende stoffen (inclusief de GMT voor vervuilende stoffen in vis en visproducten) te behalen. Wel is er een kennisopgave met betrekking tot opkomende stoffen en koper (Ministerie van I\&W en LNV, 2018).

\subsubsection{Zwerfvuil}

\section{Huidige toestand en trend}

Het overkoepelend doel voor zwerfvuil is drieledig:

- De hoeveelheid zwerfvuil op zee neemt in de loop van de tijd af;

- De hoeveelheid microafval op zee neemt op lange termijn af;

- De hoeveelheid door zeedieren opgenomen afval en microafval ligt op een niveau dat niet schadelijk is voor de gezondheid van de desbetreffende soorten.

Alleen het eerst genoemde overkoepelend doel is uitgewerkt binnen de KRM. Over de andere twee doelstellingen worden nog geen uitspraken gedaan. Voor D10C2 ontbreekt een kwantitatieve omschrijving vanwege het ontbreken van een indicator voor microplastics en bijbehorende baseline. Over effecten van afval en microafval is ook onvoldoende bekend. De KRM doelstelling voor zwerfvuil is niet gehaald (Tabel 23).

Tabel 23 Toestandsbeoordeling descriptor 10, zwerfvuil (gebaseerd op Ministerie van I\&W en LNV, 2018). De status geeft aan of de goede milieutoestand is gehaald (goed), niet gehaald (niet goed), nog niet bekend is vanwege bijvoorbeeld het ontbreken van vastgestelde grenswaarden/streefwaarden (onbekend).

\begin{tabular}{|l|l|l|l|}
\hline Criteria & Goede milieutoestand & Indicator & Status \\
\hline \multirow{5}{*}{ D10C1 } & $\begin{array}{l}\text { Voor afval op stranden: een significante dalende trend in het } \\
\text { totaal van de meest voorkomende categorieën afval (die } \\
\text { bijdragen aan } 80 \text { procent van de totale hoeveelheid afval) die } \\
\text { op het strand worden aangetroffen }\end{array}$ & OSPAR - Strandafval & NL - Strandafval \\
\cline { 2 - 4 } & $\begin{array}{l}\text { Voor drijvend afval, korte termijn: Een significant dalende } \\
\text { trend van het aantal noordse stormvogels met meer dan 0,1 } \\
\text { gr plastic deeltjes in de maag gedurende de afgelopen tien } \\
\text { jaar. }\end{array}$ & $\begin{array}{l}\text { OSPAR - Plastic in } \\
\text { zeevogelmagen }\end{array}$ & $\begin{array}{l}\text { NL - Plastic in } \\
\text { zeevogelmagen }\end{array}$ \\
\cline { 2 - 4 } & $\begin{array}{l}\text { Voor zeebodem afval: significante afname van de hoeveelheid } \\
\text { afval op de zeebodem }\end{array}$ & OSPAR - Zeebodemafval \\
\cline { 3 - 4 } & De hoeveelheid microafval op zee neemt op lange termijn af & Neen - Zeebodemafval \\
\hline (D10C2) & $\begin{array}{l}\text { De hoeveelheid door zeedieren opgenomen afval en microafval } \\
\text { ligt op een niveau dat niet schadelijk is voor de gezondheid } \\
\text { van de desbetreffende soorten }\end{array}$ & Geen & Onbekend \\
\hline \multirow{2}{*}{ (D10C3) } & Onbekend \\
\hline
\end{tabular}


De OSPAR-beoordeling van strandafval en plastic in magen van stormvogels laten zien dat er nog geen sprake is van significante afnames (Tabel 24 en Figuur 48, respectievelijk). Afval op de zeebodem is wijdverspreid (Figuur 49), maar is op bepaalde plaatsen op zee en langs de kust wel kansrijker aan te treffen dan op andere plaatsen. Deze indicator is echter nog niet voldoende ontwikkeld om uitspraken over de GMT mogelijk te maken. Er wordt dus nog niet voldaan aan de GMT voor zwerfvuil, maar de toestand verbetert wel. Zo is in de Nederland voor het eerst een significante afnemende trend (over 10 jaar) voor zowel het gewicht van gebruikersplastics als industriële plastics aangetoond voor de in Nederland aangespoelde stormvogels in de periode 2006-2015. Ook zijn in Nederland significante afnemende trends van strandafval op de Nederlandse stranden in de periode 2010-2015 en 2011-2016 (Ministerie van I\&W en LNV, 2018).

Tabel 24 OSPAR Indicator strandafval: resultaten per gebruikscategorie van afval van de strandsurveys van de zuidelijke Noordzee in de periode 2009-2014 (OSPAR, 2017)

$\begin{array}{lrr}\text { Categorie } & \begin{array}{c}\text { Gemiddeld aantal per } \\ \text { meter kustlijn }\end{array} & \begin{array}{c}\text { Relatieve trend \% toename of } \\ \text { afname per jaar }\end{array} \\ \text { Plastic/polystyreen } & 400,2 & -7,6 \\ \text { Hout } & 12,2 & -5,1 \\ \text { Rubber } & 8,2 & 5,3 \\ \text { Metaal } & 7,5 & -12,0 \\ \text { Glas } & 7,2 & 0,2 \\ \text { Papier/karton } & 6,4 & -17,5 \\ \text { Sanitair afval } & 6 & -5,7 \\ \text { Kleding/textiel } & 3 & -12,2 \\ \text { Keramiek } & 0,6 & -2,3 \\ \text { Medisch afval } & 0,3 & 1,5\end{array}$

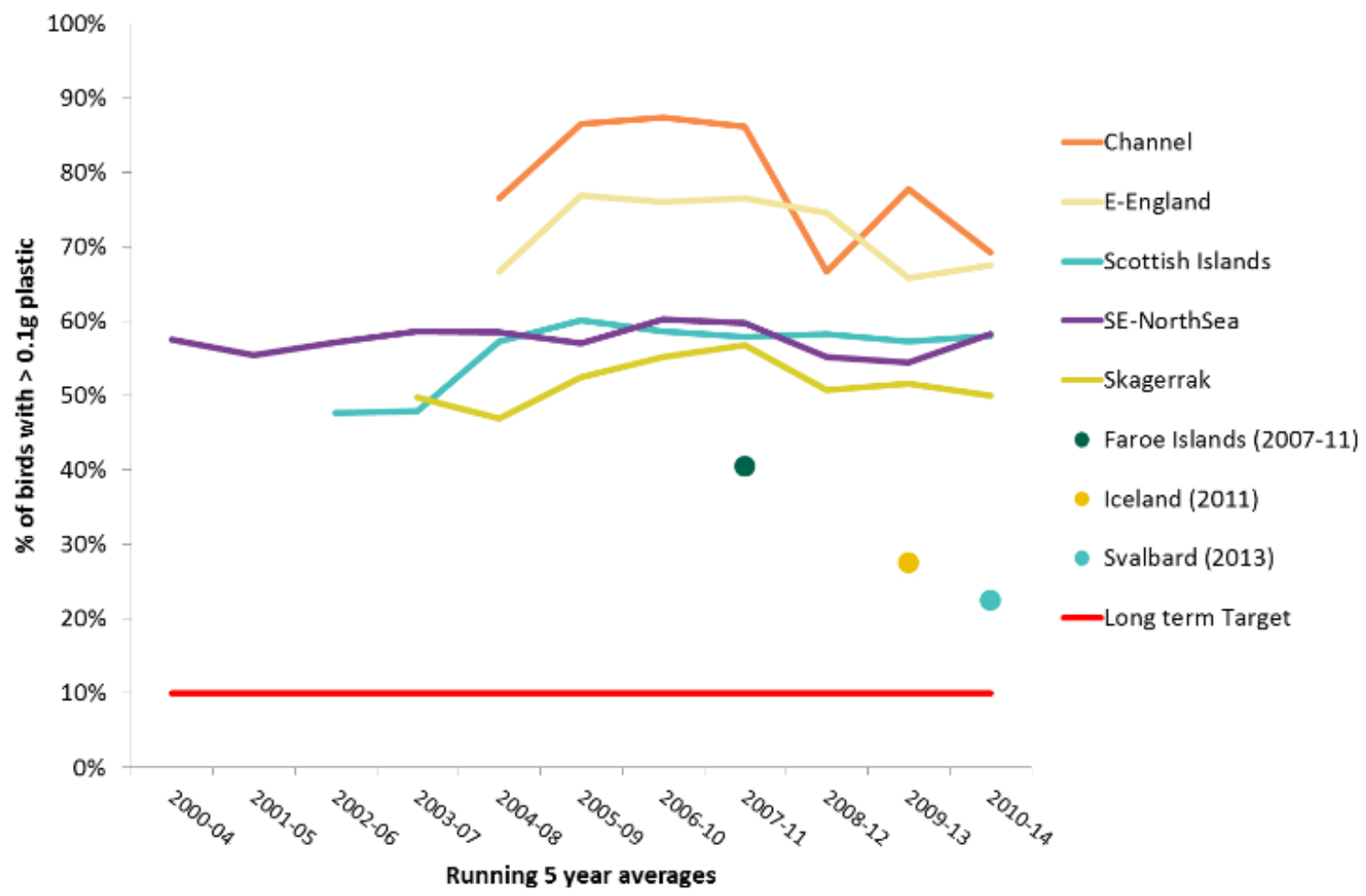

Figuur 48 OSPAR Indicator plastic in zeevogelmagen: vijf-jaargemiddelde aantal stormvogels (\%) met meer dan 0,1 g plastic in de maag sinds 2000 en/of het jaar van deelname aan het monitoringprogramma (OSPAR, 2017). 


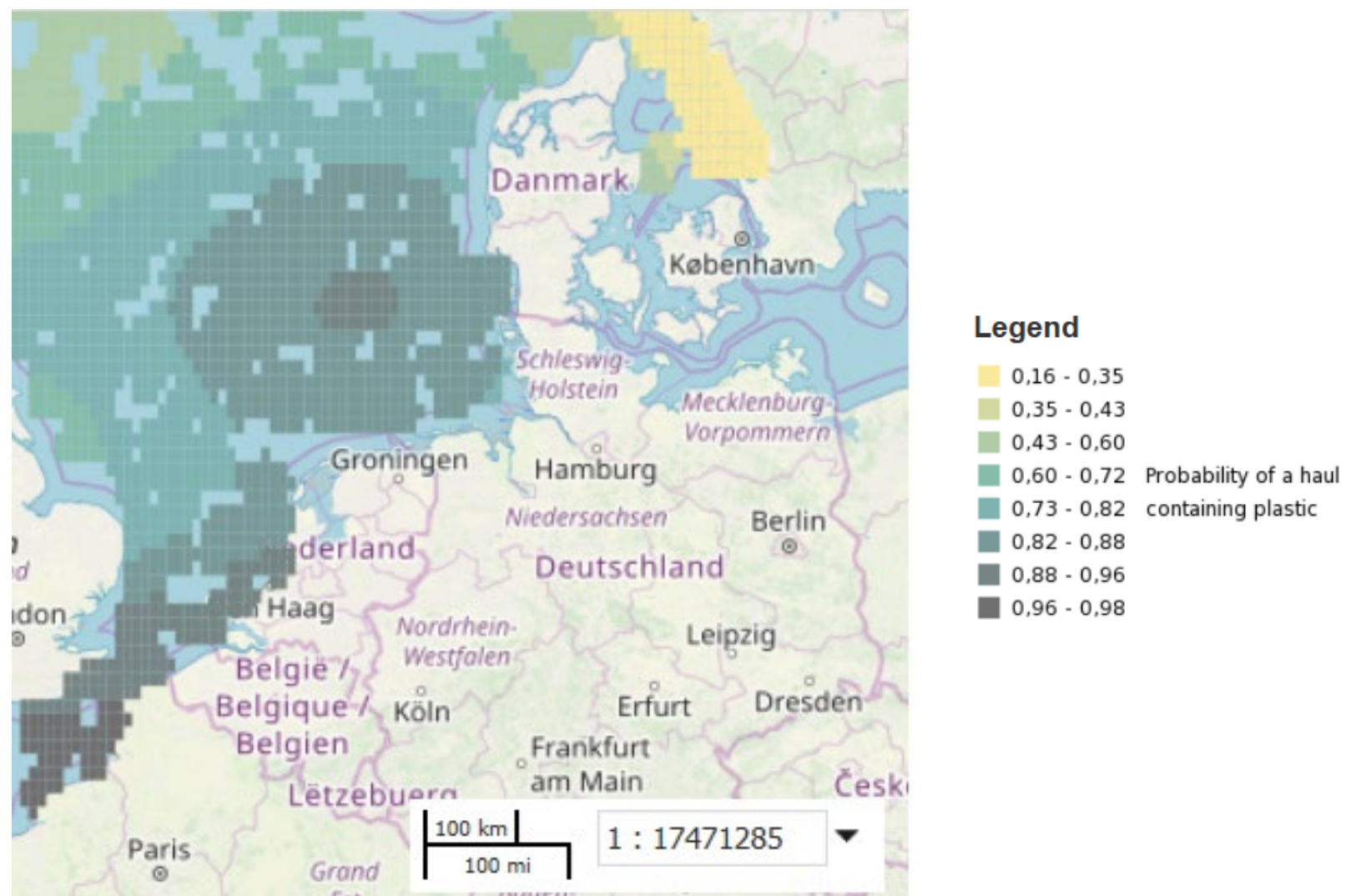

Figuur 49 OSPAR Indicator zeebodemafval: de kans dat afval wordt aangetroffen per $\mathrm{km}^{2}$ (https://odims.ospar.org).

\section{Belangrijke activiteiten en drukfactoren}

De belangrijkste activiteiten op zee die bijdragen aan het risico van zwerfvuil die geïdentificeerd zijn door gebruik te maken van de CEA zijn verschillende vormen van visserij, toerisme en recreatie, scheepvaart. De belangrijkste activiteiten die genoemd worden in de Nederlandse KRM komen hier mee overeen, waarbij ook scheepvaart en activiteiten op land worden aangeduid (Figuur 50).

Voor de visserij gaat het met name om het verlies van vistuig. Voor scheepvaart en recreatie gaat het om afval dat (per ongeluk) over boord gaat. Dit komt overeen met het type afval dat het meest wordt aangetroffen op alle onderzoekslocaties in het OSPAR-zeegebied, zijnde plastic fragmenten, gevolgd door verpakkingsmateriaal (van etenswaar, maar ook flessen) en vistuig (Ministerie van I\&W en LNV, 2018). 


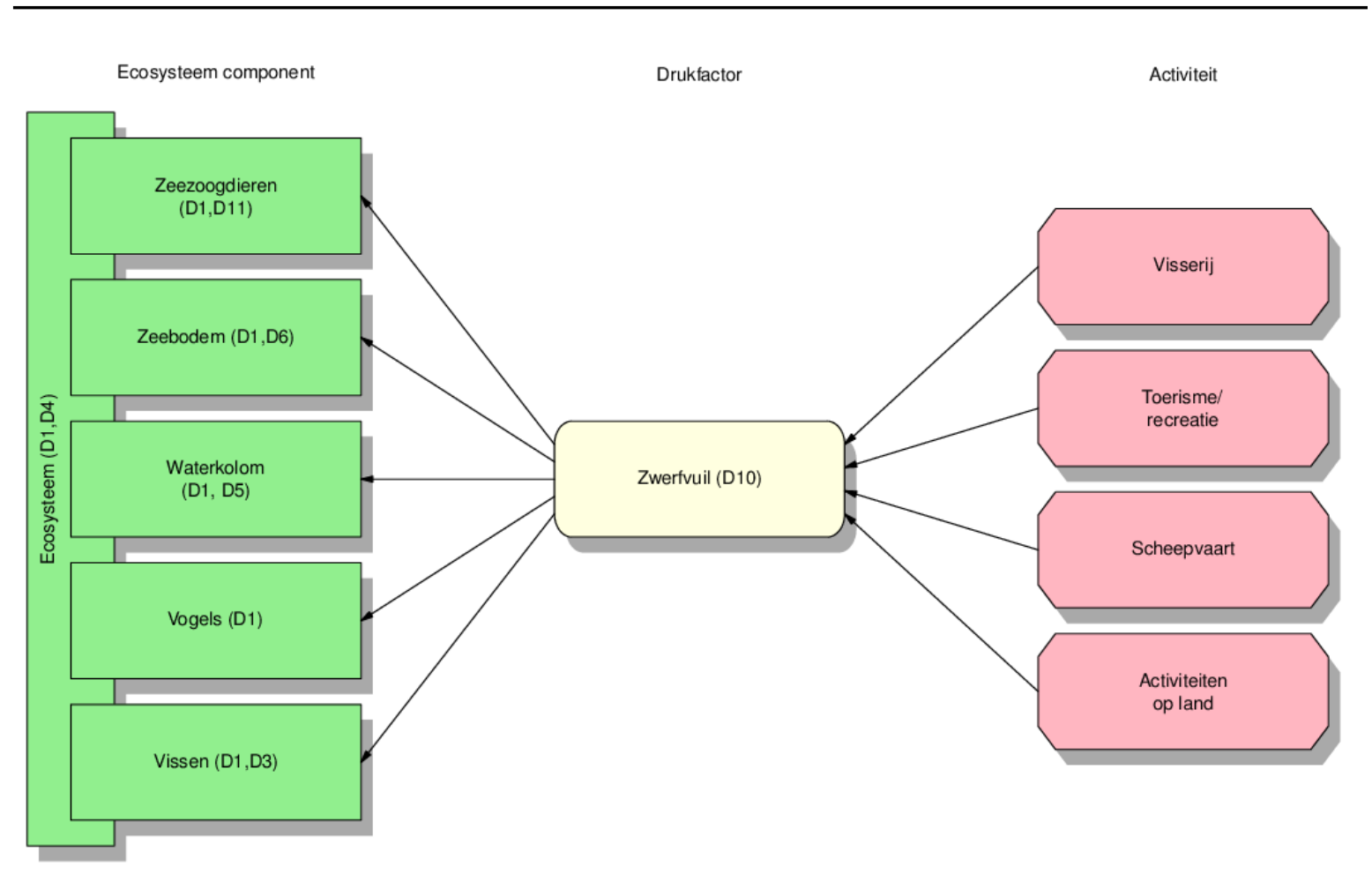

Figuur 50 De drukfactor 'zwerfvuil', de activiteiten die daar invloed op hebben en de gerelateerde onderdelen van het Noordzee ecosysteem. De relaties zijn zoveel mogelijk gebaseerd op informatie vanuit de Nederlandse KRM (Ministerie van IenM en EZ, 2014; Ministerie van I\&W en LNV, 2018). D1 Biodiversiteit; D2 Niet-inheemse soorten; D3 Commerciële visbestanden; D4 Voedselweb; D5 Eutrofiering; D6 Bodemintegriteit; D7 Hydrografische eigenschappen; D8 Vervuilende stoffen; D9 Vervuilende stoffen in vis; D10 Zwerfvuil; D11 Energietoevoer, o.m. onderwatergeluid.

\section{Milieudoelen en beleidsmaatregelen}

De milieudoelen om de voortgang tot GMT voor zwerfvuil te begeleiden zijn (Ministerie van I\&W en LNV, 2018):

- D10T1: op regionaal niveau toewerken naar kwantitatieve (regionale) streefdoelen voor strandafval (bv. 30 procent reductie) en plastic in magen van noordse stormvogels (10 procent van de vogels; OSPAR EcoQO).

- D10T2: op regionaal Noordzeeniveau werken aan de ontwikkeling van een indicator voor microplastics in sediment.

De selectie van maatregelen uit het programma van maatregelen (2015), zoals aangegeven door het Ministerie van I\&W en LNV (2018):

- $\quad$ agendering en bewustwording, cursuspakketten;

- schoonmaakacties stranden;

- Green Deal Schone Stranden;

- $\quad$ aanpak Schone Maas, uitbreiding naar andere stroomgebieden, ophaalregeling zwerfvuil;

- Green Deal Scheepsafvalketen, implementatie EU Richtlijn havenontvangstvoorzieningen;

- lozingsverbod zeeschepen (MARPOL);

- $\quad$ Fishing for Litter (visserij);

- Green Deal Visserij voor een Schone Zee;

- $\quad$ uitvoering afvalstoffenbeleid;

- terugdringing gebruik plastic tassen en ballonnen;

- vermindering microplastics in cosmetica en schoonmaakmiddelen.

In de Mariene Strategie (Ministerie van I\&W en LNV, 2018) staat aangegeven dat het aanvullend beleid uit 2012 moet worden gecontinueerd om de GMT voor zwerfvuil te behalen. De aanvullende beleidsopgave uit 2012 was als volgt geformuleerd (Ministerie van IenM \& ELenI, 2012): 
- Aanvullend brongericht beleid voor de aanpak van zwerfafval, afkomstig van strandrecreatie, de visserij, rivieren en de scheepvaart. Aan de afvalstroom in rivieren wil Nederland aandacht aanbesteden in het kader van het 'reframen' van de KRW.

- Bewustwording over de gevolgen van plastic afval in zee is een belangrijk onderdeel van preventie. Het kabinet zal daarom bewustwording over plastic afval in zee stimuleren.

- Productontwikkeling en duurzamer en efficiënter gebruik van in het bijzonder plastics moet meer onder de aandacht komen. Dit past in het concept van de 'groene groei' die het kabinet in de duurzaamheidsagenda voorstaat. Economie en milieu kunnen goed samengaan en dit biedt kansen aan de private sector. Het concept van 'cradle to cradle' kan in dit verband worden genoemd.

Gezien het internationale karakter van het probleem, zou worden gezocht naar internationale samenwerking om tot effectief beleid te komen (Ministerie van IenM \& ELenI, 2012). Aan de hand van de recente beoordeling is er ook een kennisopgave vastgesteld met betrekking tot rivierafval, microplastics en de effecten op het mariene ecosysteem (Ministerie van I\&W en LNV, 2018).

\subsubsection{Onderwatergeluid}

\section{Huidige toestand en trend}

Onderwatergeluid valt onder KRM descriptor 11, energietoevoer, waarvoor twee overkoepelende doelstellingen worden gehanteerd (Ministerie van I\&W en LNV, 2018):

- Impulsgeluid: ruimtelijke spreiding, tijdsduur en geluidsniveaus van luide impulsieve bronnen zijn zodanig dat directe en indirecte effecten van luid impulsieve geluid niet de gunstige staat van instandhouding van soorten in gevaar kan brengen.

- Continu geluid: ruimtelijke spreiding, tijdsduur en niveaus van achtergrondgeluid is zodanig dat dit niet de gunstige staat van instandhouding van soorten in gevaar kan brengen. Voor continu geluid is het nog niet mogelijk om een kwantitatieve omschrijving van de goede milieutoestand op te stellen, omdat gegevens over niveaus en trends van continu geluid (ook internationaal) nog niet beschikbaar zijn.

Het is onbekend of de KRM doelstelling voor onderwatergeluid is gehaald vanwege het ontbreken van grenswaarden en voldoende meetgegevens (Tabel 25).

Tabel 25 Toestandsbeoordeling descriptor 11, antropogeen geluid (gebaseerd op Ministerie van I\&W en LNV, 2018). De status geeft aan of de goede milieutoestand is gehaald (goed), niet gehaald (niet goed), nog niet bekend is vanwege bijvoorbeeld het ontbreken van vastgestelde grenswaarden/streefwaarden (onbekend).

\begin{tabular}{|l|l|l|l|}
\hline Criteria & Goede milieutoestand & Indicator & Status \\
\hline D11C1 & $\begin{array}{l}\text { Ruimtelijke spreiding, tijdsduur en geluidsniveaus van luide } \\
\text { impulsieve bronnen zijn zodanig dat directe en indirecte } \\
\text { effecten van luid impulsieve geluid niet de gunstige staat van } \\
\text { instandhouding van soorten in gevaar kan brengen. Voor } \\
\text { bruinvissen wordt reductie van populatiegrootte voorkomen } \\
\text { door het stellen van een limiet aan het aantal } \\
\text { bruinvisverstoringsdagen door het introduceren van } \\
\text { geluidsbudgetten voor de bouw van windparken. }\end{array}$ & OSPAR - Impulsgeluid & Aanvullende NL beoordeling \\
\hline D11C2 & $\begin{array}{l}\text { Voor continu geluid is het nog niet mogelijk om een } \\
\text { kwantitatieve omschrijving van de goede milieutoestand op te } \\
\text { stellen }\end{array}$ & $\begin{array}{l}\text { Nog geen indicator } \\
\text { beschikbaar }\end{array}$ \\
\hline
\end{tabular}

In OSPAR-verband is een gezamenlijk impulsgeluidregister opgezet, wat ook als KRM indicator is opgenomen. Het verwachtte impulsgeluid ten gevolge van seismisch onderzoek, explosies, heien en sonar wordt aan OSPAR gerapporteerd in pulsblokdagen (Pulse Block Days: het aantal dagen binnen een kalenderjaar waarbij impulsgeluid wordt veroorzaakt binnen een bepaald gebied, meestal ICES blokken) wordt uitgedrukt. Er is echter nog geen limiet ontwikkeld; er wordt in OSPAR verband nog gewerkt aan het verder ontwikkelen van deze indicator. Een eerste analyse van de gegevens over 2015 laat zien dat er in de tijd grote verschillen zijn in het aantal bronnen en in hun ruimtelijke spreiding (Figuur 51 en Figuur 52). De ruimtelijke spreiding van het impulsgeluid in 2016 (Figuur 53) verschilt sterk met de situatie in 2015. Weliswaar ontbreken nog meetgegevens over een langere periode, maar het is al wel duidelijk dat de activiteiten van jaar tot jaar sterk kunnen verschillen (Ministerie van I\&W en LNV, 2018). 


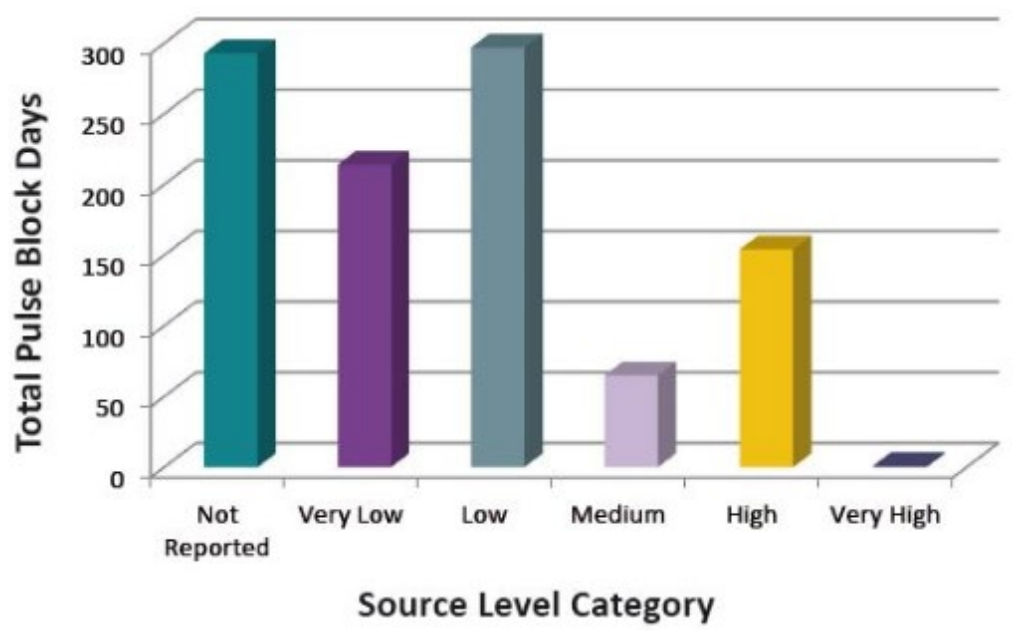

Figuur 51 OSPAR Indicator impulsgeluid: Pulse block days per bron categorie (relatieve intensiteit van geluid) voor de gehele Noordzee in 2015 (OSPAR, 2017).

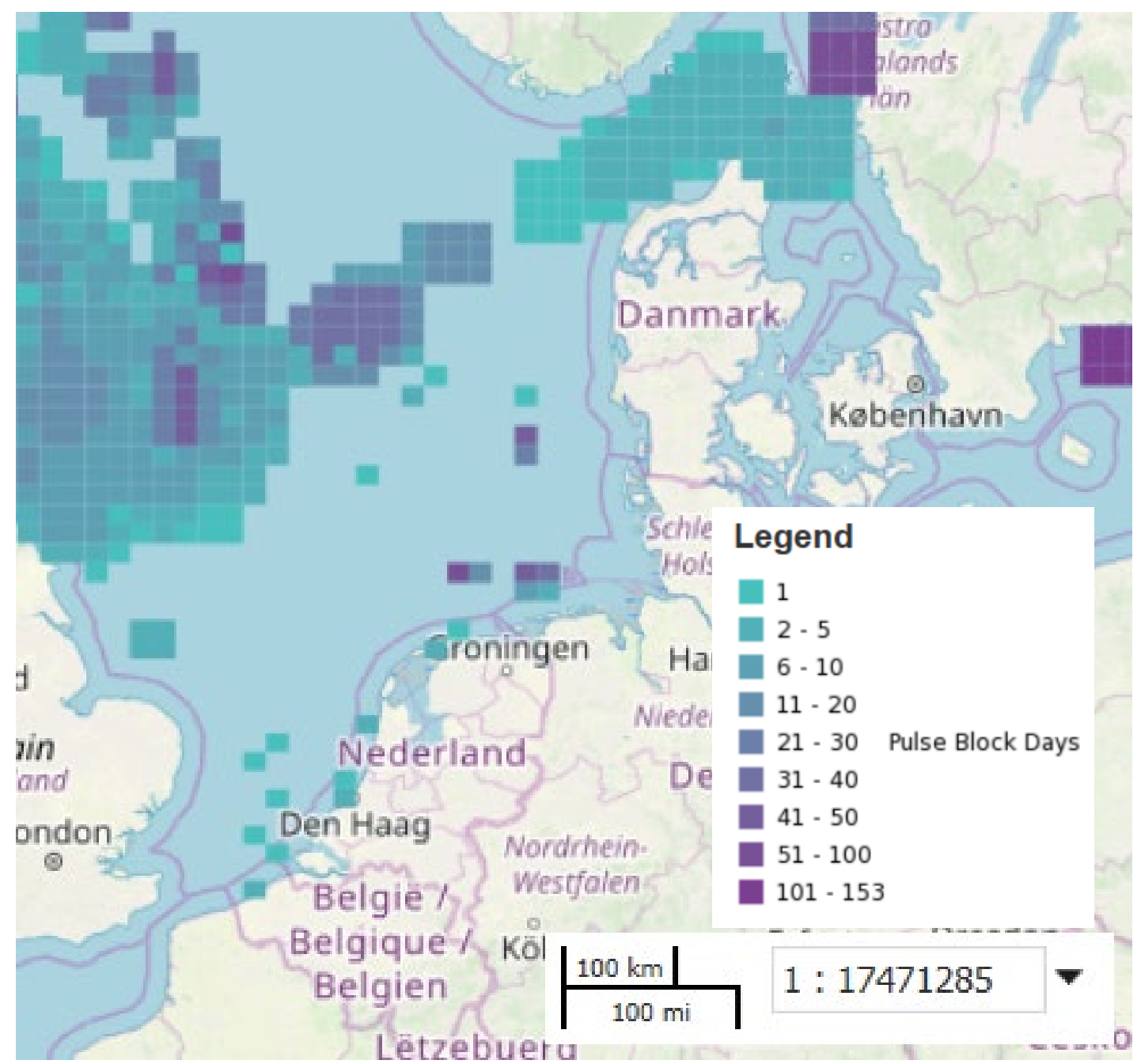

Figuur 52 OSPAR Indicator impulsgeluid: Pulse block days gerapporteerd in 2015 (https://odims.ospar.org). 


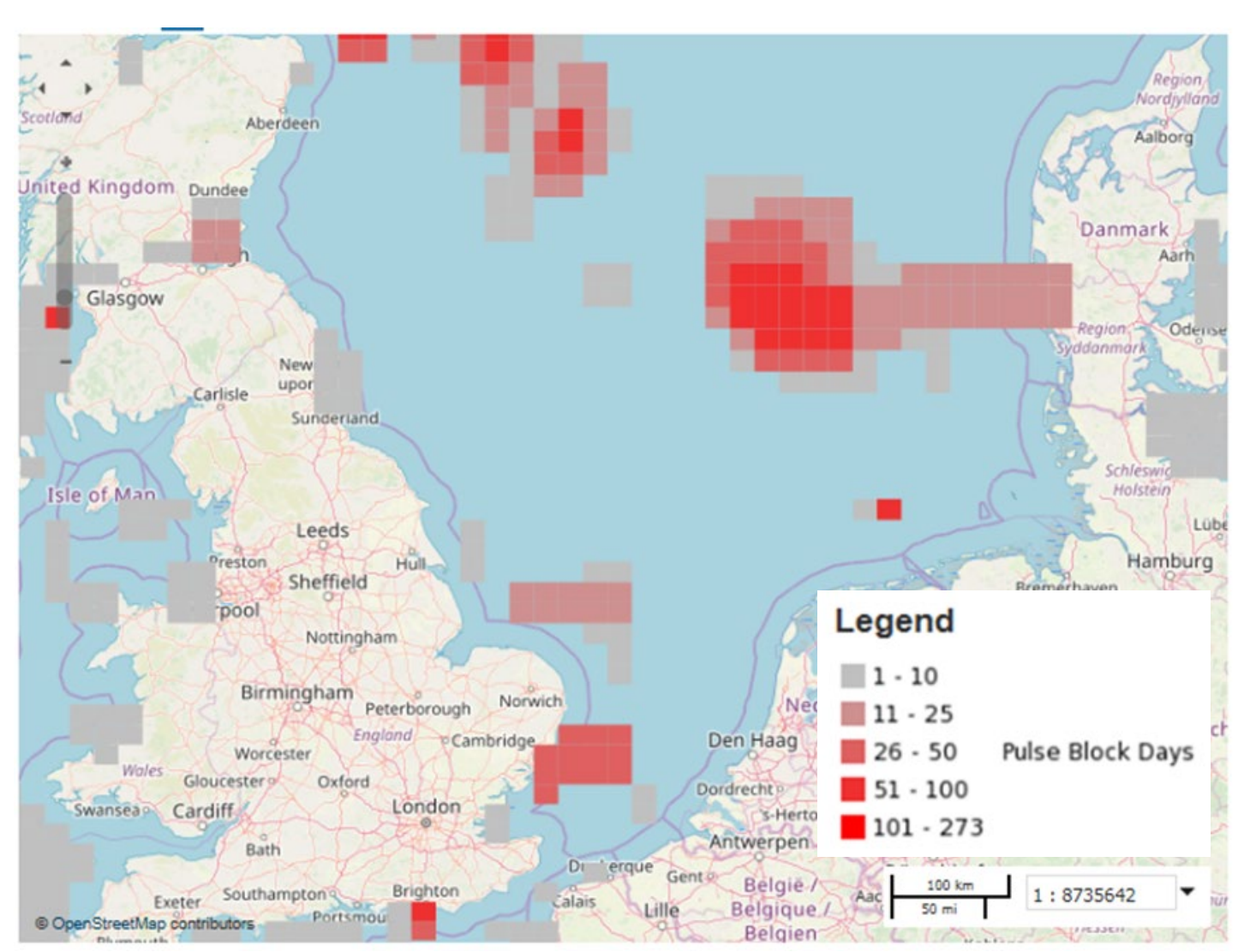

Figuur 53 OSPAR Indicator impulsgeluid: Pulse block days gerapporteerd in 2016 (https://odims.ospar.org).

Uit nationaal onderzoek blijkt dat de bouw van nieuwe windparken kan leiden tot een onaanvaardbare reductie van de bruinvispopulatie (TNO, 2015). Als reactie daarop is de regulering aangepast: er worden voorwaarden in de kavelbesluiten gesteld om significante effecten op het ecosysteem te voorkomen. Om specifiek voor de bruinvissen het aantal verstoringsdagen te beperken, zijn geluidsvoorschriften opgenomen in de kavelbesluiten (Ministerie van I\&W en LNV, 2018).

Ook de OSPAR Indicator "Abundantie en verspreiding walvisachtigen" is een relevante KRM indicator gerelateerd aan deze descriptor (Ministerie van I\&W en LNV, 2018). Deze is al eerder beschreven in paragraaf 4.2.1 (zeezoogdieren).

$\mathrm{Er}$ is nog onvoldoende bekend om de status voor onderwatergeluid te kunnen beoordelen. Dit gaat met name om het volgende (Ministerie van I\&W en LNV, 2018):

- $\quad \mathrm{Er}$ is nog geen internationale overeenstemming over de interpretatie van de gegevens en beoordeling van de effecten van impulsgeluid op ecosysteemniveau.

- De status op regionaal niveau is onbekend, omdat er slechts 1 jaar (2015) aan data beschikbaar is met daarin veel variatie.

- Voor het Nederlandse deel van de Noordzee zijn de gegevens van 2015 waarschijnlijk niet representatief (geen seismiek, bouw van windparken zonder reductie van geluidsniveaus, wat volgens de Kavelbesluiten vanaf 2016 niet meer mogelijk is).

- $\quad$ Een drempelwaarde zoals beschreven in het Commissiebesluit die alle impulsief geluid producerende activiteiten dekt moet op EU niveau worden afgestemd, dit proces is pas begonnen in 2017 en zal daarna worden voortgezet.

\section{Belangrijke activiteiten en drukfactoren}

De belangrijkste activiteiten die bijdragen aan het risico van onderwatergeluid die geïdentificeerd zijn door gebruik te maken van de CEA zijn militaire activiteiten, windmolenparken, olie- en gasactiviteiten, scheepvaart en delfstoffenwinning. Deze komen grotendeels overeen met de activiteiten die genoemd zijn in de Nederlandse implementatie van KRM (Figuur 54). 


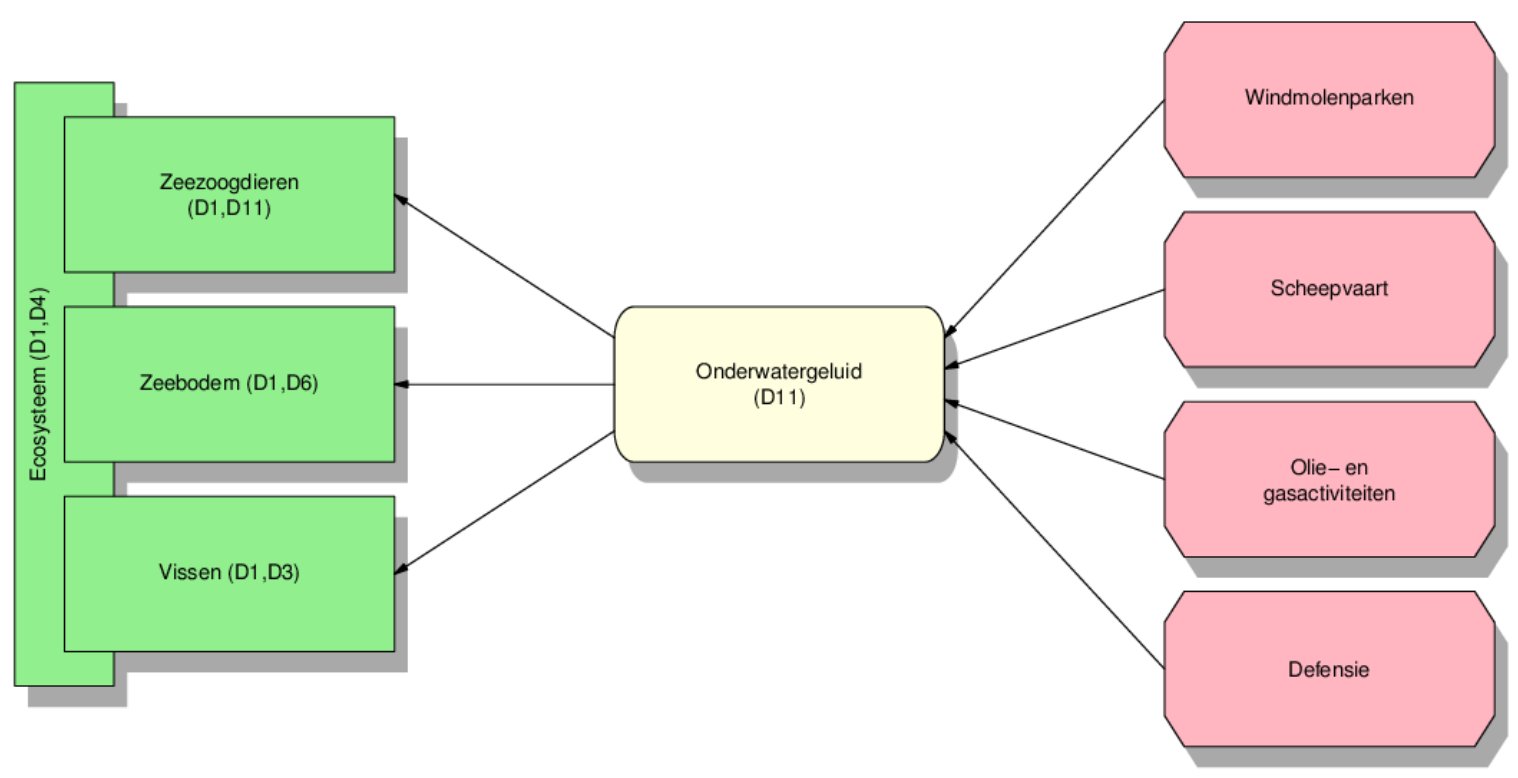

Figuur 54 De drukfactor 'onderwatergeluid', de activiteiten die daar invloed op hebben en de gerelateerde onderdelen van het Noordzee ecosysteem. De relaties zijn zoveel mogelijk gebaseerd op informatie vanuit de Nederlandse KRM (Ministerie van IenM en EZ, 2014; Ministerie van I\&W en LNV, 2018). D1 Biodiversiteit; D2 Niet-inheemse soorten; D3 Commerciële visbestanden; D4 Voedselweb; D5 Eutrofiering; D6 Bodemintegriteit; D7 Hydrografische eigenschappen; D8 Vervuilende stoffen; D9 Vervuilende stoffen in vis; D10 Zwerfvuil; D11 Energietoevoer, o.m. onderwatergeluid.

\section{Milieudoelen en beleidsmaatregelen}

De milieudoelen om de voortgang tot GMT voor onderwatergeluid te begeleiden zijn (Ministerie van I\&W en LNV, 2018):

- D11T1: het voortzetten van de aangescherpte regelgeving omtrent de preventie van schadelijke effecten door impulsgeluid.

- D11T2: ontwikkelen van een limiet voor het aantal verstoringsdagen op regionaal niveau (OSPAR).

- D11T3: het opstarten van een internationaal monitoring- programma voor continugeluid om het niveau en de verspreiding van continugeluid in kaart te brengen.

De selectie van maatregelen uit het programma van maatregelen (2015), zoals aangegeven door het Ministerie van I\&W en LNV (2018):

- vergunningvereisten aanleg windparken;

- gedragscode explosievenruiming;

- voorschriften sonargebruik Defensie;

- regelgeving seismisch onderzoek;

- uitvoering IMO-richtlijnen onderwatergeluid scheepvaart.

In de Mariene Strategie (Ministerie van I\&W en LNV, 2018) is geconcludeerd dat het bestaand beleid voldoet om de GMT voor onderwatergeluid te behalen. Wel is er een kennisopgave met betrekking tot cumulatie en continu geluid (Ministerie van I\&W en LNV, 2018). 


\subsection{Ecosysteemdiensten}

Ecosysteemdiensten zijn door de natuur aan mensen geleverde diensten en worden steeds vaker gebruikt om de kosten en baten van biodiversiteit door te rekenen. Als zodanig is er steeds meer aandacht voor ecosysteemdiensten als ordenend principe voor duurzaam beheer van natuurlijk kapitaal. Dit is terrestrisch verder ontwikkeld dan voor het mariene systeem maar in deze paragraaf toch een eerste aanzet om te laten zien hoe de verschillende ecosysteem componenten bijdrage aan de verschillende ecosysteem diensten. Daartoe hebben we gebruik gemaakt van de methodologie ontwikkeld om het risico voor de opbrengst van ecosysteemdiensten ("risk to ecosystem service supply") in te schatten voor aquatische systemen (zowel marien als binnenwateren) binnen Europa (Culhane et al., 2019; Teixeira et al., 2019) (Tabel 26). De ecosysteemdienst-benadering is ook opgenomen in beleidskaders zoals de KRM (EC, 2008) en de Biodiversiteitsstrategie (EC, 2011).

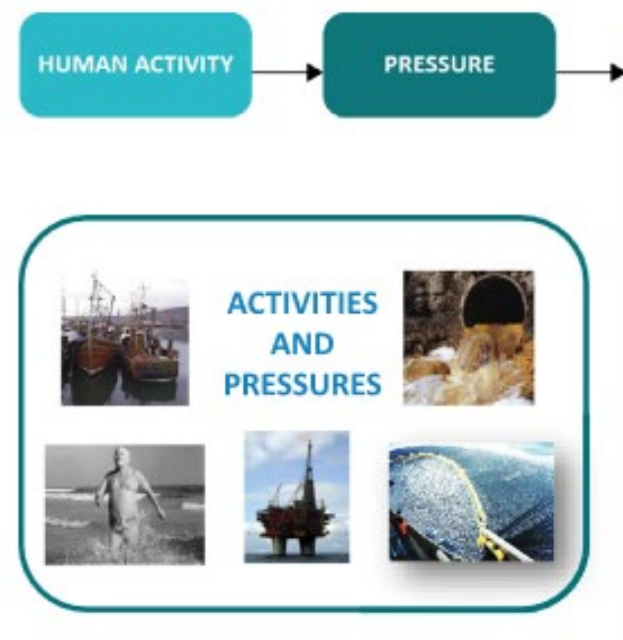

IMPACT RISK SCORE
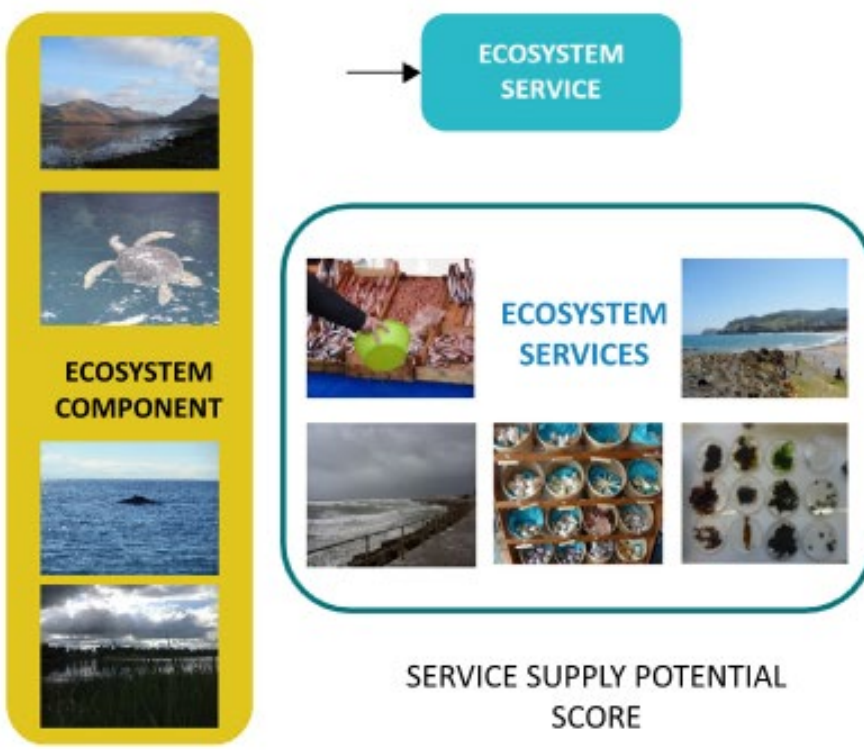

SERVICE SUPPLY POTENTIAL SCORE

Figuur 55 Schematische weergave van de methode om het risico voor de opbrengst van ecosysteemdiensten in te schatten (Culhane et al., 2019). 
Tabel 26 Bijdrage van Noordzee ecosysteem componenten aan ecosysteemdiensten ( $X$ = bijdrage; lege cel = geen bijdrage). Vanwege hun verschillende bijdrage aan ecosysteemdiensten zijn de voornaamste habitattypen onderscheiden voor de zeebodem.

Ecosysteemdiensten




\section{Integrale beoordeling}

\subsection{Introductie}

Deze integrale beoordeling voor de NatuurBalans Noordzee is gebaseerd op de informatie gepresenteerd in Hoofdstuk 4. Een samenvattende tabel van een deel van die informatie (alleen de toestandsbeoordeling) is hieronder opgenomen (Tabel 27). Voor een integrale toestandsbeoordeling kan de informatie zoals gepresenteerd in Tabel 27 op verschillende manieren geaggregeerd worden. We presenteren in dit rapport de resultaten van twee verschillende aggregaties gebaseerd op de karakterisering van het Noordzee ecosysteem zoals in Tabel 4 (Hoofdstuk 4) weergegeven. De aggregatie per descriptor (paragraaf 5.2) heeft een directe beleidsrelevantie omdat het direct laat zien of de beleidsdoelstellingen (in dit geval echter alleen KRM) gehaald zijn. De aggregatie per ecosysteemcomponent en drukfactor (paragraaf 4.3) is wat meer generiek en heeft het voordeel dat het conceptueel helder is en zich beter vertaalt naar beheer. Uiteraard zijn, afhankelijk van het beoogde doel, andere aggregaties ook mogelijk.

In dit hoofdstuk wordt de evaluatie gepresenteerd op een vergelijkbare manier als voor andere Balans van de leefomgeving rapportages. Daarin wordt geëvalueerd wat de effecten zijn van het beleid voor natuur, waarbij wordt aangegeven in hoeverre de beleidsdoelen zijn gehaald en of de overheid nog meer kan doen om de beleidsdoelen te halen. Hierbij wordt gebruik gemaakt van onderstaande stoplichten, die een bondig overzicht geven van de mate waarin doelen naar verwachting tijdig worden gehaald.

\footnotetext{
Symbool Betekenis

Uitvoering van het beleid leidt waarschijnlijk tot het halen van het doel

Geraamde ontwikkeling ligt rond het doel, beleid zou robuust gemaakt kunnen worden voor tegenvallers

Geraamde ontwikkeling leidt waarschijnlijk niet tot het halen van het doel, met intensivering van het beleid is het doel wel realiseerbaar

Geraamde ontwikkeling leidt waarschijnlijk niet tot het halen van het doel, vraagt fundamentele herziening van de huidige aanpak door andere beleidsinstrumenten in te zetten of door doelen aan te passen Op dit moment niet te bepalen

Deze analyse is niet uitgevoerd
}

Voor deze NatuurBalans Noordzee hebben we bovenstaand enigszins aangepast aan de bestaande mariene toetsingskaders en zijn de te gebruiken symbolen uitgebreid. Omdat deze integrale toestandbeoordeling specifiek gericht is op de KRM wordt de GMT gebruikt om te beoordelen of de beleidsdoelstellingen gehaald zijn. Hier zouden echter ook concepten uit andere beleidskaders voor gebruikt kunnen worden.

Beleidsevaluatie:

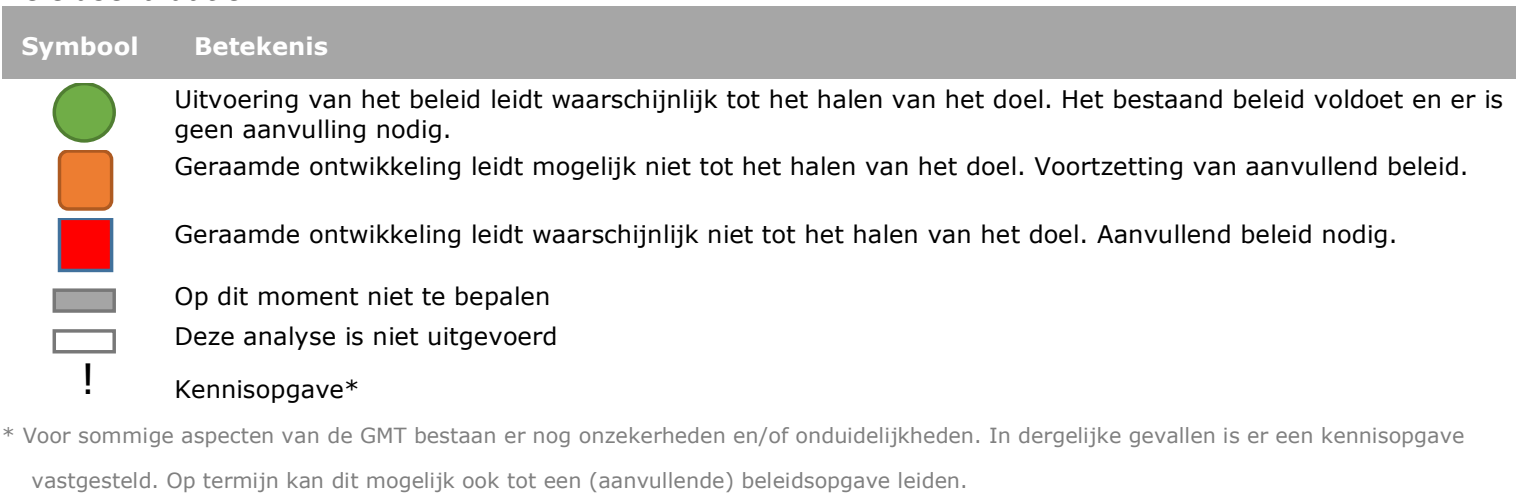


Beoordeling Goede Milieutoestand (GMT):

Bymbool Betekenis
GMT (nog) niet bereikt
Onduidelijk of GMT is bereikt / op dit moment niet te bepalen
Deze analyse is niet uitgevoerd

Volgens de KRM wordt de milieutoestand bepaald aan de hand van elf descriptoren, die de toestand van het mariene ecosysteem en verstoringen van het mariene ecosysteem als gevolg van menselijke activiteiten beschrijven. Per descriptor wordt aan de hand van criteria beoordeeld of de goede milieutoestand (GMT) is bereikt.

In Tabel 27 staat voor iedere KRM Descriptor de beoordeling per criterium en indicator vermeld.

Tabel 27 Toestandsbeoordeling KRM Descriptoren en criteria (gebaseerd op Ministerie van I\&W en $L N V$, 2018). De status geeft aan of de goede milieutoestand is gehaald (goed), niet gehaald (niet goed), nog niet bekend is vanwege bijvoorbeeld het ontbreken van vastgestelde grenswaarden/streefwaarden (onbekend). Voor sommige criteria is geen status gerapporteerd (-)

\begin{tabular}{|c|c|c|c|}
\hline Criteria & Goede milieutoestand & Indicator & Status \\
\hline \multicolumn{4}{|c|}{ Biodiversiteit: Vogels } \\
\hline $\mathrm{D} 1 \mathrm{C} 2$ & $\begin{array}{l}\text { Voor elke functionele groep is de populatieomvang van ten } \\
\text { minste } 75 \text { procent van de soorten boven de } \\
\text { drempelwaarde van } 1992 \text { (OSPAR beoordelingswaarde). }\end{array}$ & $\begin{array}{l}\text { OSPAR - Abundantie zeevogels } \\
\text { (Marine Bird Abundance) }\end{array}$ & Niet goed \\
\hline $\mathrm{D} 1 \mathrm{C} 2$ & $\begin{array}{l}\text { Populaties van zeevogels moeten voldoen aan de } \\
\text { landelijke doelen vanuit de VR. }\end{array}$ & NL - VR Beoordeling vogels & - \\
\hline D1C3 & $\begin{array}{l}\text { Voor iedere soort mag een gebrek aan broedsucces in niet } \\
\text { meer dan drie van zes jaar optreden (OSPAR- } \\
\text { beoordelingswaarde) }\end{array}$ & $\begin{array}{l}\text { OSPAR - Broedsucces of } \\
\text { broedfalen zeevogels (Marine } \\
\text { Bird breeding success or failure) }\end{array}$ & Niet goed \\
\hline \multicolumn{4}{|c|}{ Biodiversiteit: Visgemeenschap } \\
\hline D1C5 & $\begin{array}{l}\text { Vermindering barrières in de trekroutes, zodat deze } \\
\text { uiterlijk in } 2027 \text { geen belemmering zijn voor duurzame } \\
\text { populaties in het stroomgebied (KRW). }\end{array}$ & NL - KRW Vismigratieknelpunten & Niet goed \\
\hline $\mathrm{D} 1 \mathrm{C} 2$ & $\begin{array}{l}\text { Populatie van trekvissen fint (H1103), zalm }(\mathrm{H} 1106) \text {, } \\
\text { zeeprik (H1095), rivierprik ( } \mathrm{H} 1099) \text { en Elft }(\mathrm{H} 1102) \text { moet } \\
\text { voldoen aan gunstige referentiewaarde voor de populatie- } \\
\text { omvang (FRP) uit de habitatrichtlijn }\end{array}$ & $\mathrm{NL}$ - HR Beoordeling trekvissen & Niet goed \\
\hline D1C4 & $\begin{array}{l}\text { Verspreiding van trekvissen fint (H1103), zalm (H1106), } \\
\text { zeeprik (H1095), rivierprik (H1099) en Elft (H1102) in het } \\
\text { rivierengebied voldoet aan gunstige referentiewaarde voor } \\
\text { de verspreiding(FRR) uit de habitatrichtlijn. }\end{array}$ & $\mathrm{NL}$ - HR Beoordeling trekvissen & Niet goed \\
\hline D1C2 & $\begin{array}{l}\text { Toename van het aandeel kwetsbare soorten vissen in de } \\
\text { visgemeenschap (OSPAR). }\end{array}$ & $\begin{array}{l}\text { OSPAR - FC1 Herstel van } \\
\text { populaties van gevoelige soorten }\end{array}$ & Niet goed \\
\hline D4C3 & $\begin{array}{l}\text { Toename van het aandeel grote vissen in de } \\
\text { visgemeenschap (OSPAR). }\end{array}$ & $\begin{array}{l}\text { OSPAR - FC2 Aandeel grote } \\
\text { vissen in visgemeenschappen }\end{array}$ & Onbekend \\
\hline D1C2 & Commerciële vispopulaties conform D3 & GVB - FMSY en paaibiomassa. & Niet goed \\
\hline D1C2 & $\begin{array}{l}\text { Verbeteren van de populatieomvang van haaien en roggen } \\
\text { in de Noordzee en vooral in de kustzone. }\end{array}$ & Geen & Niet goed \\
\hline \multicolumn{4}{|c|}{ Biodiversiteit: Zeezoogdieren } \\
\hline \multirow[t]{2}{*}{ D1C4 } & \multirow{2}{*}{$\begin{array}{l}\text { Verspreiding van de bruinvis en de gewone zeehond } \\
\text { voldoet aan de gunstige referentiewaarde voor de } \\
\text { verspreiding (FRR) uit de habitatrichtlijn }\end{array}$} & $\begin{array}{l}\text { OSPAR - Zeehonden abundantie } \\
\text { en verspreiding (M3) }\end{array}$ & - \\
\hline & & $\begin{array}{l}\text { OSPAR - Walvisachtigen } \\
\text { abundantie en verspreiding (M4- } \\
\text { B) }\end{array}$ & - \\
\hline D1C3 & $\begin{array}{l}\text { Geen afname in het geboortecijfer van de grijze zeehond } \\
\text { van meer dan } 1 \text { procent sinds de laatste assessment en } \\
\text { niet meer dan } 25 \text { procent afname sinds } 1992 \text { (OSPAR). }\end{array}$ & $\begin{array}{l}\text { OSPAR - Pupaanwas grijze } \\
\text { zeehond (M5) }\end{array}$ & Goed \\
\hline D1C1 & $\begin{array}{l}\text { Bijvangst van bruinvissen is lager dan } 1 \text { procent van de } \\
\text { best bruikbare populatieschatting (ASCOBANS). }\end{array}$ & OSPAR - Bruinvisbijvangst (M6) & Goed \\
\hline D11C1 & $\begin{array}{l}\text { Voor impulsgeluid (D11C1): Ruimtelijke spreiding, } \\
\text { tijdsduur en geluidsniveaus van luide impulsieve bronnen } \\
\text { zijn zodanig dat directe en indirecte effecten van luid } \\
\text { impulsgeluid niet de gunstige staat van instandhouding } \\
\text { van soorten in gevaar kan brengen (zie verdere uitwerking } \\
\text { bij D11). }\end{array}$ & OSPAR - Impulsgeluid & Onbekend \\
\hline \multirow[t]{2}{*}{$\mathrm{D} 1 \mathrm{C} 2$} & \multirow{2}{*}{$\begin{array}{l}\text { De populatie van de grijze zeehond (H1364), gewone } \\
\text { zeehond (H1365) en de bruinvis (H1351) voldoen aan de } \\
\text { gunstige referentie- waarde voor de populatieomvang } \\
\text { (FRP) vanuit de Habitatrichtlijn }\end{array}$} & $\begin{array}{l}\text { OSPAR - Walvisachtigen } \\
\text { abundantie en verspreiding (M4- } \\
\text { B) }\end{array}$ & Goed \\
\hline & & $\begin{array}{l}\text { OSPAR - Zeehonden abundantie } \\
\text { en verspreiding (M3) }\end{array}$ & Goed \\
\hline D1C5 & $\begin{array}{l}\text { Behoud van de omvang en kwaliteit van het leefgebied } \\
\text { van de grijze zeehond (H1364), de gewone zeehond } \\
\text { (H1365) en de bruinvis ( } \mathrm{H} 1351) \text {. }\end{array}$ & $\begin{array}{l}\mathrm{NL}-\mathrm{HR} \text { - Beoordeling grijze en } \\
\text { gewone zeehond en bruinvis. }\end{array}$ & Niet goed \\
\hline \multicolumn{4}{|c|}{ Biodiversiteit: Pelagische habitats } \\
\hline D1C6 & $\begin{array}{l}\text { Voor pelagische habitats is de goede milieutoestand } \\
\text { bereikt wanneer de ruimtelijke en temporele variatie in de } \\
\text { plankton gemeenschap binnen de een langjarige }\end{array}$ & $\begin{array}{l}\text { OSPAR PH1/FW5 - } \\
\text { Veranderingen in fytoplankton- } \\
\text { en zoöplanktongemeenschappen }\end{array}$ & Onbekend \\
\hline
\end{tabular}




\begin{tabular}{|c|c|c|c|}
\hline D1C6 & $\begin{array}{l}\text { bandbreedte blijft die duidt op een goede milieutoestand. } \\
\text { De te gebruiken bandbreedtes moeten in de tweede cyclus } \\
\text { nog regionaal worden vastgesteld }\end{array}$ & $\begin{array}{l}\text { OSPAR PH2 - Veranderingen in } \\
\text { biomassa van fytoplankton en } \\
\text { abundantie van zoöplankton }\end{array}$ & Onbekend \\
\hline \multicolumn{4}{|c|}{ Biodiversiteit: Benthische habitats } \\
\hline D6C3 & $\begin{array}{l}\text { Voor de habitats die in het kader van de habitatrichtlijn } \\
\text { zijn beschreven, gelden de instandhoudingsdoelen voor } \\
\text { deze habitats. }\end{array}$ & $\begin{array}{l}\mathrm{NL}-\mathrm{HR} \text { beoordeling } \mathrm{H} 1110 \text { en } \\
\mathrm{H} 1170\end{array}$ & Niet goed* \\
\hline D6C3 & $\begin{array}{l}\text { Verbetering kwaliteit van de beoordeelde gebieden en } \\
\text { habitats op het NL deel van de Noordzee }\end{array}$ & $\begin{array}{l}\text { NL - Benthische Indicator } \\
\text { Soorten Index (BISI) }\end{array}$ & Onbekend \\
\hline D6C5 & $\begin{array}{l}\text { De diversiteit van benthos vertoont geen afnemende trend } \\
\text { in de beoordeelde gebieden (OSPAR) }\end{array}$ & $\begin{array}{l}\text { OSPAR - Conditie van } \\
\text { benthische gemeenschappen } \\
\text { (MMI) }\end{array}$ & Onbekend \\
\hline \multicolumn{4}{|c|}{ Niet-inheemse soorten } \\
\hline \multirow[t]{2}{*}{$\mathrm{D} 2 \mathrm{C} 1$} & \multirow[t]{2}{*}{$\begin{array}{l}\text { Dalende trend in het aantal introducties van niet-inheemse } \\
\text { soorten per beleidsperiode ( } 6 \text { jaar). }\end{array}$} & $\begin{array}{l}\text { OSPAR - Trends in nieuwe } \\
\text { gegevens over niet-inheemse } \\
\text { soorten (NIS) die zijn } \\
\text { geïntroduceerd door menselijke } \\
\text { activiteiten. }\end{array}$ & Onbekend \\
\hline & & $\begin{array}{l}\text { D2: Periodiek overzicht van } \\
\text { vastgestelde niet-inheemse } \\
\text { soorten van het Nederlandse } \\
\text { deel van de Noordzee en hun } \\
\text { transportvectoren; op basis van } \\
\text { de best beschikbare kennis. }\end{array}$ & Goed \\
\hline \multicolumn{4}{|c|}{ Commerciële visbestanden } \\
\hline $\mathrm{D} 3 \mathrm{C} 1$ & $\begin{array}{l}\text { Voor ieder commercieel bevist visbestand geldt dat de } \\
\text { sterfte door visserij (F) op de waarde of kleiner dan de } \\
\text { waarde blijft die behoort bij een maximale duurzame } \\
\text { oogst (Maximum Sustainable Yield, MSY): F } \text { Fmsy (CFP). }\end{array}$ & GVB - FMSY & Niet goed \\
\hline $\mathrm{D} 3 \mathrm{C} 2$ & $\begin{array}{l}\text { De biomassa van paaibestanden (Spawning Stock Biomass } \\
\text { of SSB) van commercieel beviste vis, schaal- of } \\
\text { schelpdieren ligt boven het voorzorgniveau MSY Btrigger } \\
\text { (in lijn met ICES-vangstadviezen; CFP). }\end{array}$ & GVB - paaibiomassa & Niet goed \\
\hline \multicolumn{4}{|c|}{ Voedselweb } \\
\hline D4C1 & $\begin{array}{l}\text { De diversiteit (soortsamenstelling en de abundantie) van } \\
\text { ten minste drie geselecteerde trofische gildes is op een } \\
\text { niveau of binnen de een normale bandbreedte die duidt op } \\
\text { een goede milieutoestand. De te gebruiken trofische gildes } \\
\text { en de niveaus en bandbreedtes moeten in de tweede } \\
\text { cyclus nog regionaal worden vastgesteld. }\end{array}$ & Geen & Onbekend \\
\hline D4C2 & $\begin{array}{l}\text { De verhouding in abundantie tussen ten minste drie } \\
\text { geselecteerde trofische gildes is op een niveau of binnen } \\
\text { de een normale bandbreedte die duidt op een goede } \\
\text { milieutoestand. De te gebruiken trofische gildes en de } \\
\text { niveaus en bandbreedtes moeten in de tweede cyclus nog } \\
\text { regionaal worden vastgesteld }\end{array}$ & Geen & Onbekend \\
\hline D4C3 & $\begin{array}{l}\text { De groottestructuur ( lengte) van de visgemeenschap blijft } \\
\text { boven de historische minimum waarde }\end{array}$ & $\begin{array}{l}\text { OSPAR - FW3 Grootteverdeling } \\
\text { in visgemeenschappen }\end{array}$ & Onbekend \\
\hline \multicolumn{4}{|c|}{ Eutrofiëring } \\
\hline \multicolumn{4}{|c|}{ Kustwateren } \\
\hline \multirow[t]{2}{*}{ D5C1 } & $\begin{array}{l}\text { De nutriëntenconcentraties in de winter voldoen in de } \\
\text { kustwateren aan de normen van de KRW }\end{array}$ & $\mathrm{NL}-\mathrm{KRW}$-beoordeling & Niet goed \\
\hline & $\begin{array}{l}\text { De nutriëntenconcentraties in de winter voldoen aan de } \\
\text { beoordelingswaarden van de OSPAR }\end{array}$ & OSPAR Nutriëntconcentraties & Niet goed \\
\hline \multirow[t]{2}{*}{ D5C2 } & $\begin{array}{l}\text { Algenbiomassa (vastgesteld op basis van chlorofyl-a } \\
\text { metingen) in de kustwateren is niet hoger dan de goede } \\
\text { toestand conform de KRW voor de desbetreffende } \\
\text { kustwatertypen }\end{array}$ & $\mathrm{NL}-\mathrm{KRW}$-beoordeling & Niet goed \\
\hline & $\begin{array}{l}\text { Algenbiomassa (vastgesteld op basis van chlorofyl-a } \\
\text { metingen) voldoen aan de beoordelingswaarden van } \\
\text { OSPAR. }\end{array}$ & OSPAR Chlorofylconcentraties & Goed \\
\hline \multirow[t]{2}{*}{ D5C5 } & $\begin{array}{l}\text { De onderste waterlaag (gestratificeerde wateren) of de } \\
\text { oppervlaktelaag van gemengde wateren in de kustwateren } \\
\text { is ten minste met } 60 \text { procent zuurstof verzadigd }\end{array}$ & $\mathrm{NL}-\mathrm{KRW}$-beoordeling & Goed \\
\hline & $\begin{array}{l}\text { In de kustwateren wordt in de onderste waterlaag } \\
\text { (stratified waters) of in de oppervlaktelaag van gemengde } \\
\text { wateren ten minste } 6 \mathrm{mg} / \mathrm{l} \text { zuurstof gevonden }\end{array}$ & $\begin{array}{l}\text { OSPAR Opgeloste } \\
\text { zuurstofconcentraties }\end{array}$ & Goed \\
\hline \multicolumn{4}{|c|}{ Offshore wateren } \\
\hline D5C1 & $\begin{array}{l}\text { De nutriëntenconcentraties in de winter voldoen aan de } \\
\text { beoordelingswaarden van de OSPAR }\end{array}$ & OSPAR Nutriëntconcentraties & Goed \\
\hline D5C2 & $\begin{array}{l}\text { Algenbiomassa (vastgesteld op basis van chlorofyl-a } \\
\text { metingen) in de offshore wateren voldoen aan de } \\
\text { beoordelingswaarden van OSPAR. }\end{array}$ & OSPAR Chlorofylconcentraties & Goed \\
\hline D5C5 & $\begin{array}{l}\text { In de offshore wateren wordt in de onderste waterlaag } \\
\text { (gestratificeerde wateren) of in de oppervlaktelaag van } \\
\text { gemengde wateren ten minste } 6 \mathrm{mg} / \mathrm{l} \text { zuurstof gevonden. }\end{array}$ & $\begin{array}{l}\text { OSPAR Opgeloste } \\
\text { zuurstofconcentraties }\end{array}$ & Goed \\
\hline \multicolumn{4}{|c|}{ Zeebodemintegriteit } \\
\hline \multicolumn{4}{|c|}{ ysiek verlies } \\
\hline D6C1 & $\begin{array}{l}\text { Geen significant verlies van de natuurlijke zeebodem ten } \\
\text { opzichte van de situatie in } 2012 \text { als gevolg van menselijke } \\
\text { activiteiten. }\end{array}$ & $\begin{array}{l}\mathrm{NL} \text { - D6 - Spreiding en } \\
\text { ruimtelijke omvang fysiek } \\
\text { verlies. }\end{array}$ & Goed \\
\hline D6C4 & $\begin{array}{l}\text { Geen significant verlies als gevolg van menselijke } \\
\text { activiteiten van de habitats die in het kader van de KRM } \\
\text { beschreven zijn. }\end{array}$ & $\begin{array}{l}\mathrm{NL} \text { - D6 - Spreiding en } \\
\text { ruimtelijke omvang fysiek } \\
\text { verlies. }\end{array}$ & $\begin{array}{l}\text { Waarschijn } \\
\text {-lijk goed }\end{array}$ \\
\hline
\end{tabular}




\begin{tabular}{|c|c|c|c|}
\hline D6C2 & $\begin{array}{l}\text { Geen toename in de fysieke verstoring in de tijd op de } \\
\text { totale zeebodem van de gehele Noordzee en het NCP. }\end{array}$ & $\begin{array}{l}\text { ICES/NLD6 - } \\
\text { Visserijdrukindicator. }\end{array}$ & Onbekend \\
\hline D6C3 & $\begin{array}{l}\text { Geen toename in de fysieke verstoring in de tijd over de } \\
\text { habitats die in het kader van de KRM zijn beschreven. }\end{array}$ & $\begin{array}{l}\text { ICES/NLD6 - } \\
\text { Visserijdrukindicator. }\end{array}$ & Onbekend \\
\hline D6C3 & $\begin{array}{l}\text { Voor de habitats die in het kader van de habitatrichtlijn } \\
\text { zijn beschreven, gelden de instandhoudingsdoelen voor } \\
\text { deze habitats. }\end{array}$ & $\begin{array}{l}\mathrm{NL}-\mathrm{HR} \text { beoordeling } \mathrm{H} 1110 \text { en } \\
\mathrm{H} 1170\end{array}$ & $\begin{array}{l}\text { Niet } \\
\text { goed** }\end{array}$ \\
\hline D6C3 & $\begin{array}{l}\text { Verbetering kwaliteit van de beoordeelde gebieden en } \\
\text { habitats op het NL deel van de Noordzee (Benthische } \\
\text { Indicator Soorten Index). }\end{array}$ & $\begin{array}{l}\text { NL - Benthische Indicator } \\
\text { Soorten Index (BISI) }\end{array}$ & Onbekend* \\
\hline D6C5 & $\begin{array}{l}\text { De diversiteit van benthos vertoont geen afnemende trend } \\
\text { in de beoordeelde gebieden (OSPAR) }\end{array}$ & $\begin{array}{l}\text { OSPAR - Conditie van } \\
\text { benthische gemeenschappen } \\
\text { (MMI) }\end{array}$ & Onbekend \\
\hline \multicolumn{4}{|c|}{ Hydrografische eigenschappen } \\
\hline D7C1 & \multirow{2}{*}{$\begin{array}{l}\text { Het mariene ecosysteem ondervindt geen negatieve } \\
\text { effecten als gevolg van permanente wijzigingen in de } \\
\text { hydrografische eigenschappen als gevolg van menselijke } \\
\text { activiteiten. }\end{array}$} & Geen & \multirow[t]{2}{*}{ Goed } \\
\hline D7C2 & & Geen & \\
\hline \multicolumn{4}{|c|}{ Vervuilende stoffen } \\
\hline \multicolumn{4}{|c|}{ Kustwateren } \\
\hline $\mathrm{D} 8 \mathrm{C} 1$ & $\begin{array}{l}\text { De concentraties van voor het mariene milieu relevante } \\
\text { vervuilende stoffen, gemeten in het meest geëigende } \\
\text { compartiment (water of biota) voldoen aan de } \\
\text { Environmental Quality Standards die bij de KRW worden } \\
\text { gebruikt in de } 12 \text {-mijls zone (voor prioritaire stoffen) } \\
\text { respectievelijk in de 1-mijlszone (voor alle overige } \\
\text { stoffen). }\end{array}$ & $\begin{array}{l}\mathrm{NL} \text { - KRW specifiek } \\
\text { verontreinigende stoffen in de } \\
\text { 1-mijlszone en prioritaire } \\
\text { stoffen in de } 12 \text {-mijlszone. }\end{array}$ & Onbekend \\
\hline \multicolumn{4}{|c|}{ Offshore wateren } \\
\hline \multirow[t]{9}{*}{$\mathrm{D} 8 \mathrm{C} 1$} & \multirow{9}{*}{$\begin{array}{l}\text { De concentraties van voor het mariene milieu relevante } \\
\text { vervuilende stoffen, gemeten in het meest geëigende } \\
\text { compartiment (sediment of biota) voldoen aan de milieu- } \\
\text { evaluatiecriteria (Environmental Assessment Criteria, EAC) } \\
\text { en/of achtergrondevaluatiecriteria (Background } \\
\text { Assessment Criteria, BAC) van OSPAR, of ze laten, waar } \\
\text { deze streefwaarden nog niet zijn geformuleerd, een } \\
\text { dalende trend zien (conform OSPAR). }\end{array}$} & OSPAR - PAK's in biota & Onbekend \\
\hline & & OSPAR - PAK's in sediment & Niet goed \\
\hline & & OSPAR - PCB's in biota & Goed \\
\hline & & OSPAR - PCB's in sediment & Goed \\
\hline & & OSPAR - PBDE's in biota & Niet goed \\
\hline & & OSPAR - PBDE's in sediment & Onbekend \\
\hline & & OSPAR - organotin in sediment & Goed \\
\hline & & OSPAR - metalen in biota & Niet goed \\
\hline & & OSPAR - metalen in sediment & Goed \\
\hline \multicolumn{4}{|c|}{ Overkoepelend } \\
\hline \multirow[t]{2}{*}{ D8C1 } & \multirow{2}{*}{$\begin{array}{l}\text { De concentraties van voor het mariene milieu relevante } \\
\text { vervuilende stoffen, gemeten in het meest geëigende } \\
\text { compartiment (sediment of biota) voldoen aan de milieu- } \\
\text { evaluatiecriteria (Environmental Assessment Criteria, EAC) } \\
\text { en/of achtergrondevaluatiecriteria (Background } \\
\text { Assessment Criteria, BAC) van OSPAR, of ze laten, waar } \\
\text { deze streefwaarden nog niet zijn geformuleerd, een } \\
\text { dalende trend zien (conform OSPAR). }\end{array}$} & $\begin{array}{l}\text { OSPAR - Bronnen van zware } \\
\text { metalen }\end{array}$ & Onbekend \\
\hline & & NL-koperconcentraties* & Onbekend \\
\hline $\mathrm{D} 8 \mathrm{C} 2$ & Dalende trend ten opzichte van 2012 van Imposex & OSPAR D8C2 Imposex. & Onbekend \\
\hline $\mathrm{D} 8 \mathrm{C} 3$ & $\begin{array}{l}\text { De ruimtelijke omvang en de duur van de significante } \\
\text { ernstige verontreinigingen zijn tot een minimum beperkt. }\end{array}$ & $\begin{array}{l}\text { Acute verontreinigingen: aantal } \\
\text { olielozingen en het volume per } \\
\text { incident (Bonn Agreement). }\end{array}$ & Niet goed \\
\hline \multicolumn{4}{|c|}{ Vervuilende stoffen in vis } \\
\hline $\mathrm{D} 9 \mathrm{C} 1$ & $\begin{array}{l}\text { De niveaus van vervuilende stoffen (waaronder PAK's, } \\
\text { dioxinen en zware metalen) in vis en visproducten uit de } \\
\text { Noordzee overschrijden de in de EU verordening EG } \\
1881 / 2006 \text { vastgestelde maximumgehalten niet. }\end{array}$ & $\begin{array}{l}\text { NL - Beoordeling volgens } \\
\text { EG1881/2006 }\end{array}$ & Goed \\
\hline \multicolumn{4}{|c|}{ Zwerfvuil } \\
\hline \multirow[t]{6}{*}{$\mathrm{D} 10 \mathrm{C} 1$} & \multirow{2}{*}{$\begin{array}{l}\text { Voor afval op stranden: een significante dalende trend in } \\
\text { het totaal van de meest voorkomende categorieën afval } \\
\text { (die bijdragen aan } 80 \text { procent van de totale hoeveelheid } \\
\text { afval) die op het strand worden aangetroffen }\end{array}$} & OSPAR - Strandafval & Niet goed \\
\hline & & NL - Strandafval & Goed \\
\hline & \multirow{2}{*}{$\begin{array}{l}\text { Voor drijvend afval, korte termijn: Een significant dalende } \\
\text { trend van het aantal noordse stormvogels met meer dan } \\
0,1 \text { gr plastic deeltjes in de maag gedurende de afgelopen } \\
\text { tien jaar. }\end{array}$} & $\begin{array}{l}\text { OSPAR - Plastic in } \\
\text { zeevogelmagen }\end{array}$ & Niet goed \\
\hline & & NL - Plastic in zeevogelmagen & Goed \\
\hline & \multirow{2}{*}{$\begin{array}{l}\text { Voor zeebodem afval: significante afname van de } \\
\text { hoeveelheid afval op de zeebodem }\end{array}$} & OSPAR - Zeebodemafval & Onbekend \\
\hline & & NL - Zeebodemafval & Onbekend \\
\hline D10C2 & $\begin{array}{l}\text { De hoeveelheid microafval op zee neemt op lange termijn } \\
\text { af }\end{array}$ & Geen & Onbekend \\
\hline D10C3 & $\begin{array}{l}\text { De hoeveelheid door zeedieren opgenomen afval en } \\
\text { microafval ligt op een niveau dat niet schadelijk is voor de } \\
\text { gezondheid van de desbetreffende soorten }\end{array}$ & Geen & Onbekend \\
\hline \multicolumn{4}{|c|}{ Onderwatergeluid } \\
\hline \multirow[t]{2}{*}{$\mathrm{D} 11 \mathrm{C} 1$} & \multirow[b]{2}{*}{$\begin{array}{l}\text { Ruimtelijke spreiding, tijdsduur en geluidsniveaus van } \\
\text { luide impulsieve bronnen zijn zodanig dat directe en } \\
\text { indirecte effecten van luid impulsieve geluid niet de } \\
\text { gunstige staat van instandhouding van soorten in gevaar } \\
\text { kan brengen. Voor bruinvissen wordt reductie van } \\
\text { populatiegrootte voorkomen door het stellen van een } \\
\text { limiet aan het aantal bruinvisverstoringsdagen door het } \\
\text { introduceren van geluidsbudgetten voor de bouw van } \\
\text { windparken. }\end{array}$} & OSPAR - Impulsgeluid & Onbekend \\
\hline & & Aanvullende NL beoordeling & Onbekend \\
\hline D11C2 & $\begin{array}{l}\text { Voor continu geluid is het nog niet mogelijk om een } \\
\text { kwantitatieve omschrijving van de goede milieutoestand } \\
\text { op te stellen }\end{array}$ & Nog geen indicator beschikbaar & Onbekend \\
\hline
\end{tabular}




\subsection{Evaluatie per KRM Descriptor}

Een manier om de toestand te evalueren is om een samenvatting te geven op grond van de descriptoren en bijhorende status (GMT/niet GMT/onbekend). Een dergelijke samenvatting is weergegeven in Figuur 56. Die laat zien dat voor 22 criteria de GMT is gehaald, voor 14 criteria (nog) niet is gehaald terwijl het voor 16 criteria nog onbekend is, bijvoorbeeld vanwege het gebrek aan een beoordelingsmethodiek en/of grenswaarden. Momenteel is slechts voor 2 descriptoren (D9: vervuilende stoffen in vis en D7: hydrografische eigenschappen)) de GMT gehaald.

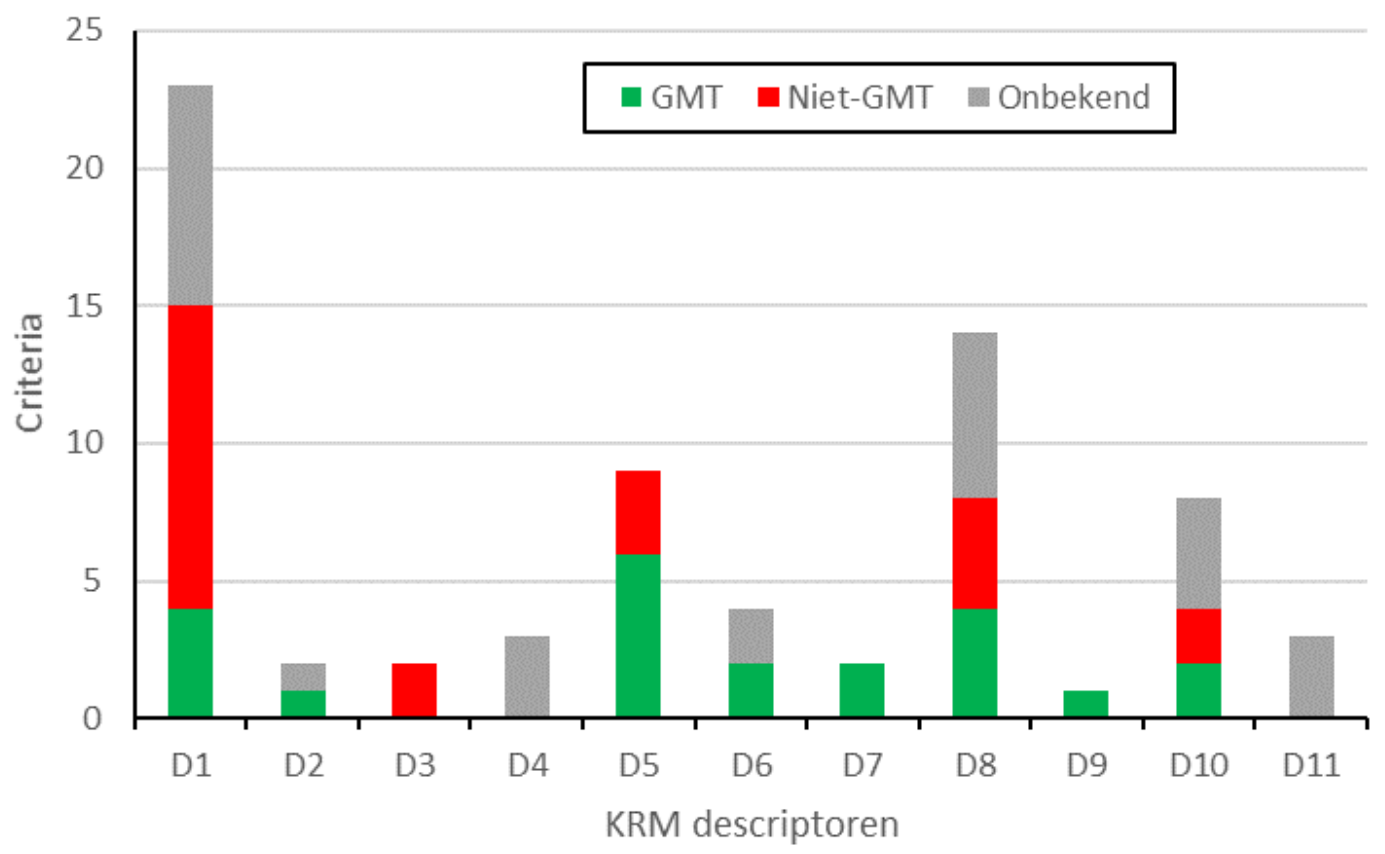

Figuur 56 Aantal criteria per descriptor waarvoor de goede milieutoestand (GMT) is bereikt, GMT niet is bereikt, of onduidelijk is (onbekend). D1 Biodiversiteit; D2 Niet-inheemse soorten; D3 Commerciële visbestanden; D4 Voedselweb; D5 Eutrofiering; D6 Bodemintegriteit; D7 Hydrografische eigenschappen; D8 Vervuilende stoffen; D9 Vervuilende stoffen in vis; D10 Zwerfvuil; D11 Energietoevoer, o.m. onderwatergeluid.

De evaluatie van het beleid aan de hand van de stoplichten staat weergeven in Tabel 28. Voor de meeste descriptoren wordt door IenM aangenomen dat het huidig beleid voldoende zou moeten zijn om het doel (de goede milieutoestand) te halen (zie ook hoofdstuk 4). Alleen voor benthische habitats en zwerfvuil is het aanvullend beleid uit 2012 noodzakelijk (de initiële beoordeling: Ministerie van IenM \& ELenI, 2012). Dat gaat om de aanvullende bodembescherming op het Friese Front en de Centrale Oestergronden en het terugdringen van zwerfvuil op zee, waaronder ook microplastics. 
Tabel 28 Evaluatie huidige toestand KRM (op basis van het Ministerie van I\&W en LNV, 2018).

Uitvoering van het beleid leidt waarschijnlijk tot het halen van het doel. Het bestaand beleid voldoet en er is geen aanvulling nodig; Geraamde ontwikkeling leidt mogelijk niet tot het halen van het doel. Voortzetting van aanvullend beleid; $\square$ Geraamde ontwikkeling leidt waarschijnlijk niet tot het halen van het doel. Aanvullend beleid nodig; $\square$ Op dit moment niet te bepalen / onduidelijk; $X$ GMT (nog) niet bereikt; $\sqrt{ }$ GMT bereikt; ! Kennisopgave, op termijn kan dit mogelijk ook tot een (aanvullende) beleidsopgave leiden

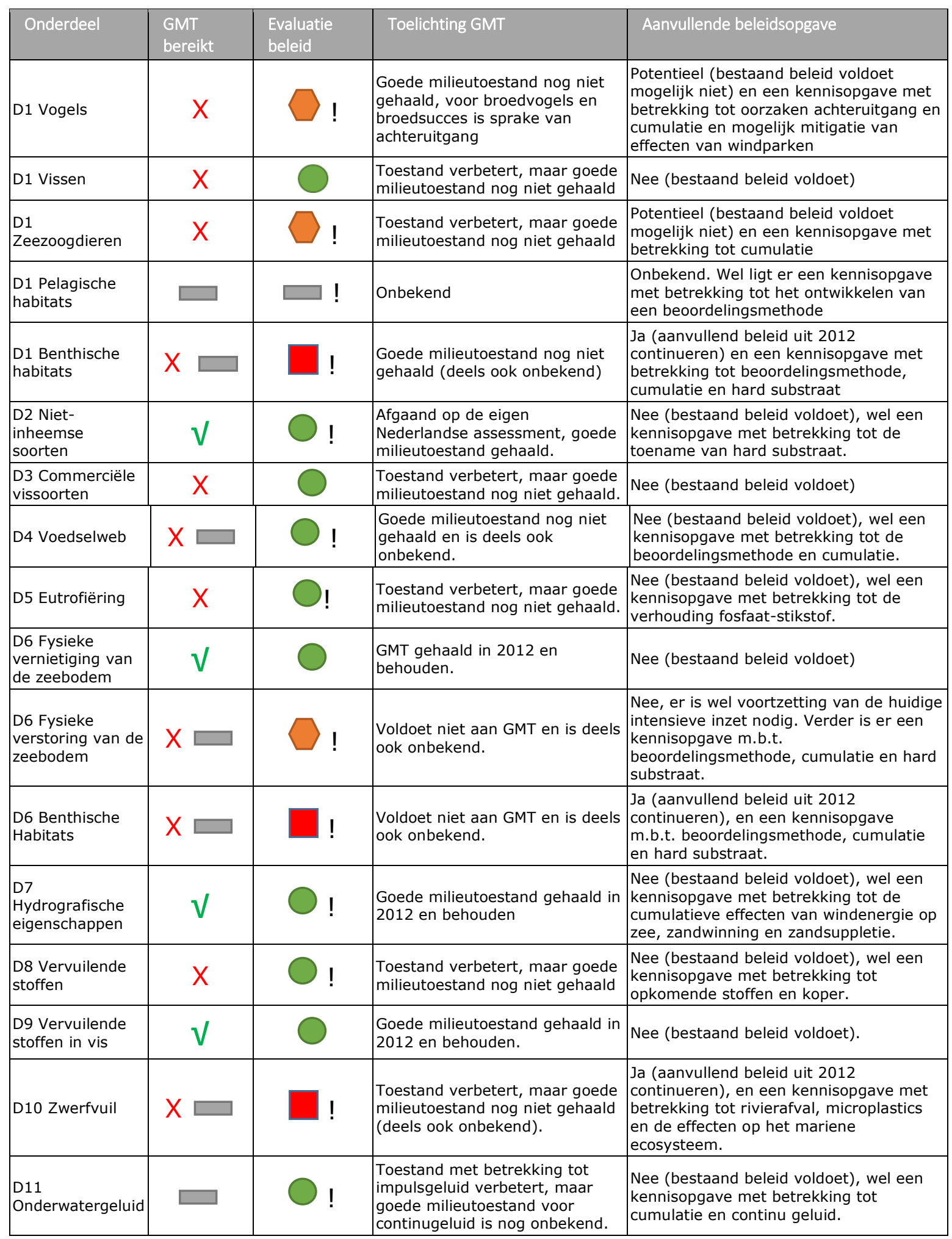

Bovenstaande tabel (Tabel 28) wordt hieronder per descriptor nader toegelicht waarbij kort wordt ingegaan op de doelstelling, huidige status en het (nodige) beleid. 


\section{D1 Biodiversiteit}

Het overkoepelend doel van de KRM biodiversiteitsdoelstelling (D1) is dat de populatiedichtheden en demografie van vogel-, vis- en zeezoogdierpopulaties duiden op gezonde populaties. Dit doel is uitgewerkt in verschillende criteria voor verschillende onderdelen (vogels, vissen, zeezoogdieren, pelagische- en benthische habitats), waarbij aan de hand van indicatoren wordt beoordeeld of aan de criteria wordt voldaan. Dit zijn indicatoren vanuit OSPAR, KRW, VHR, GVB en een aanvullende Nederlandse indicator (BISI), zie Tabel 27. De biodiversiteitsdoelstelling is nog niet bereikt (Tabel 29). Inherent aan de brede scope van deze descriptor is ook het risico wijdverspreid over verschillende activiteiten en drukfactoren. De belangrijkste drukfactoren die bijdragen aan het risico voor biodiversiteit zijn op grond van de CEA: toevoer van vervuilende stoffen, zwerfvuil, extractie van organismen en habitatverlies. Daarbij moet worden opgemerkt dat de CEA alleen directe effecten beoordeeld. Het risico door indirecte effecten blijft dus buiten beschouwing. Dit speelt met name bij visserij een belangrijke rol vanwege effecten op de voedselbeschikbaarheid, zowel door het verminderen van geschikte prooidieren als het overboord zetten van bijvangst (discards). Veel zeevogels gebruiken discards als belangrijke voedselbron. De verspreiding van tenminste de grote mantelmeeuw, kleine mantelmeeuw en zilvermeeuw wordt gestuurd door de aanwezigheid van visserij (Camphuysen et al., 1995). Voor kleine mantelmeeuw populaties is het ook aangetoond dat ze veel baat hebben gehad bij het terugzetten van ondermaatse vangst door de vissers (Camphuijsen, 2013). De aanlandplicht zal er naar verwachting voor zorgen dat er veel minder vis overboord zal gaan, en dat kan gevolgen hebben voor die soorten die momenteel gebruik maken van die vis als voedselbron. Maar hoe groot die effecten in de praktijk zullen zijn, is op basis van de huidige beperkte kennis van prooi-predator interacties niet te voorspellen (Steins et al., 2018).

Het beleid behoeft nog verdere aanpassing om de GMT voor biodiversiteit te bereiken. De kans bestaat namelijk dat de GMT verder onder druk komt te staan als gevolg van de Nederlandse en buitenlandse opgaven voor de ontwikkeling van duurzame energie op zee (Ministerie van I\&W en LNV, 2018). Dit geldt voor zeezoogdieren, vogels en benthische habitats. Alleen voor vissen, waarvoor de toestand in de afgelopen periode (2012-2018) is verbeterd, lijkt het bestaand beleid voldoende om de GMT te bereiken. Dit kan echter nog veranderen als de D4 voedselwebben verder wordt uitgewerkt. Voor zeezoogdieren is een verbetering van de toestand waargenomen, maar het bestaand beleid voldoet mogelijk niet om de GMT te bereiken. Er is daarom een kennisopgave vastgesteld om beter inzicht te krijgen in de cumulatieve effecten van nieuwe windparken op het ecosysteem (en mogelijk mitigatie) en meer specifiek op de populaties van zeezoogdieren en zeevogels en op de benthische en pelagische habitats (Ministerie van I\&W en LNV, 2018). Dit kan mogelijk tot aanvullende beleidsopgaven leiden. De (cumulatieve) effecten van aanleg en gebruik van windparken op de beschermde habitats en soortgroepen (en leefgebieden) van zeezoogdieren (bruinvis en twee soorten zeehonden), zee- en kustvogels, trekkende landvogels, onderwaterhabitats (voor bodemfauna en vis) en over de Noordzee trekkende vleermuizen worden nader onderzocht in het kader van Wozep ${ }^{3}$. Voor vogels speelt naast de ontwikkeling van windenergie op zee de aanlandplicht (geen bijvangst meer overboord) een grote rol in het bereiken van de GMT. Doordat de overboord gegooide vis een belangrijke voedselbron is voor een aantal zeevogelsoorten (vooral meeuwen), zullen de populaties van deze soorten door de aanlandplicht waarschijnlijk afnemen.

\footnotetext{
${ }^{3}$ Wozep (Windenergie op zee ecologisch programma) is een vijfjarig onderzoeksprogramma dat in 2016 is opgestart om de kennisleemtes rond de ecologische effecten van windenergie op zee te onderzoeken
} 
Tabel 29 Evaluatie huidige toestand biodiversiteit (op basis van het Ministerie van I\&W en LNV, 2018)

Onderdeel
Vogels
Vissen
Zeezoogdieren
Pelagische habitats

\section{D2 Niet-inheemse soorten}

Het overkoepelend doel voor niet-inheemse soorten (D2) is dat door menselijke activiteiten geïntroduceerde niet-inheemse soorten (exoten) voorkomen op een niveau waarbij het ecosysteem niet verandert. Daarvoor geldt het criterium D2C1: Dalende trend in het aantal introducties van nietinheemse soorten per beleidsperiode ( 6 jaar). Beschikbare indicatoren zijn de OSPAR indicator: "Trends in nieuwe gegevens over niet-inheemse soorten (NIS) die zijn geïntroduceerd door menselijke activiteiten" en de Nederlandse indicator "D2: Periodiek overzicht van vastgestelde niet-inheemse soorten van het Nederlandse deel van de Noordzee en hun transportvectoren; op basis van de best beschikbare kennis". In de huidige beleidsperiode heeft Nederland alleen gebruik gemaakt van de Nederlandse indicator (uitgewerkt door Gittenberger et al., 2017a en 2017b) op basis waarvan een dalende trend in het aantal nieuwe introducties is waargenomen (Ministerie van I\&W en LNV, 2018). Op grond van deze beoordeling is de GMT bereikt (Tabel 30).

Een belangrijke vector in de vestiging van niet-inheemse soorten is het aanbod van hard substraat. Een aandachtspunt is het inbrengen van gebiedsvreemd hard substraat in de Noordzee voor bijvoorbeeld erosiebeschermende bestorting van (nieuwe) windparken met als risico de primaire of secundaire introductie van niet-inheemse soorten in de Noordzee. Hiervoor is een kennisopgave vastgelegd.

Tabel 30 Evaluatie huidige toestand niet-inheemse soorten (op basis van het Ministerie van I\&W en $L N V, 2018)$

$\begin{array}{ll}\text { Onderdeel } & \begin{array}{l}\text { GMT } \\ \text { bereikt } \\ \text { Niet-inheemse soorten }\end{array}\end{array}$

\section{D3 Commerciële visbestanden}

Het overkoepelend doel voor commerciële visbestanden is een reductie van de visserijmortaliteit die moet leiden tot een geleidelijk herstel en behoud van populaties van visbestanden boven een biomassaniveau dat de maximale duurzame opbrengst kan opleveren. Dit zijn tevens de twee criteria waaraan moet worden voldaan (visserijmortaliteit F $\leq F M S Y$ en paaibiomassa SSB $\geq S S B M S Y$ ). De doelstelling is nog niet bereikt (Tabel 31). $\mathrm{Er}$ is wel een verbetering van de toestand waargenomen en de verwachting is dat het GVB op termijn voldoet om de GMT te bereiken (Ministerie van I\&W en LNV, 2018). Er zijn echter wel aandachtspunten bij de invoering van de aanlandplicht: er bestaat een kans dat de maatregel niet goed wordt geïmplementeerd en dus niet tot minder discards zal leiden (i.e. dat de visserij gewoon zal doorgaan en dat de vangst boven de quota komt en de minst waardevolle maten overboord gaan) (Batsleer et al., 2016); en/of dat de visserijsterfte toeneemt voor nietdoelsoorten, zoals bijvoorbeeld voor schar (van Helmond \& Steins, 2016). 
Tabel 31 Evaluatie huidige toestand commerciële visbestanden (op basis van het Ministerie van I\&W en LNV, 2018)

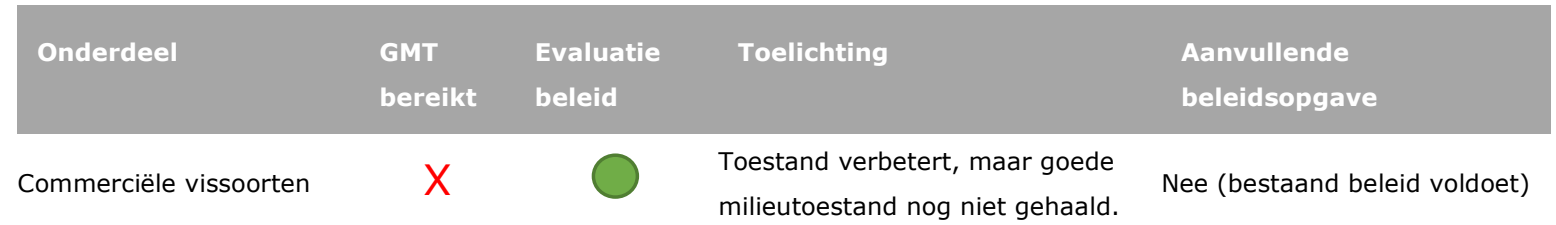

\section{D4 Voedselweb}

Het overkoepelend doel voor het voedselweb is dat het effect van menselijke interventies op interacties tussen verschillende trofische niveaus in het voedselweb wordt verminderd. Het is onduidelijk of deze doelstelling is bereikt (Tabel 32). Voedselwebben zijn complex en vormen één van de moeilijkst te beoordelen descriptoren van de KRM (Ministerie van I\&W en LNV, 2018). Er zijn drie criteria waarop de toestand van het voedselweb wordt beoordeeld: Van ten minste drie geselecteerde trofische gildes moet de diversiteit (soortsamenstelling en de abundantie) (D4C1) en de verhouding in abundantie (D4C2) op een niveau of binnen een normale bandbreedte zijn die duidt op een goede milieutoestand. Het derde criterium (D4C3) is dat de groottestructuur (lengte) van de visgemeenschap boven het historische minimum blijft.

De te gebruiken trofische gildes en de niveaus en bandbreedtes moeten in de tweede cyclus nog regionaal worden vastgesteld zodat er voor de eerste twee criteria nog geen geschikte indicatoren beschikbaar zijn. Alleen voor D4C3 is momenteel een indicator beschikbaar (OSPAR - FW3 Grootteverdeling in visgemeenschappen). Hierdoor is het niet mogelijk om te beoordelen of het voedselweb van het Nederlandse deel van de Noordzee voldoet aan de GMT. Binnen OSPAR is een actieplan ${ }^{4}$ ontwikkeld om de kennishiaten te adresseren en de beoordelingsmethoden verder te ontwikkelen en toe te passen. OSPAR heeft wel al een set van negen voedselweb indicatoren beschikbaar, waarvan drie indicatoren momenteel zijn aangenomen als 'OSPAR common indicator', zijnde FW3 Grootteverdeling in visgemeenschappen, FW4 veranderingen in gemiddeld trofisch niveau van mariene predatoren en PH1/FW5 Veranderingen in fytoplankton- en zoöplanktongemeenschappen (Haraldsson et al., 2017). Om de beoordeling van indicator- naar ecosysteem niveau te brengen is o.a. in internationaal verband gewerkt aan het integreren van voedselweb indicatoren om de KRM implementatie te ondersteunen (Haraldsson et al., 2017). Hoe de beoordeling uiteindelijk geïmplementeerd zal worden moet in de loop van de komende 6-jaarscyclus van de KRM (2018-2024) duidelijk worden.

Tabel 32 Evaluatie huidige toestand voedselweb (op basis van het Ministerie van I\&W en LNV, 2018)

\begin{tabular}{llll} 
Onderdeel & $\begin{array}{l}\text { GMT } \\
\text { bereikt }\end{array}$ & $\begin{array}{l}\text { Evaluatie } \\
\text { beleid }\end{array}$ & \multicolumn{1}{c}{ Toelichting } \\
Voedselweb & Aanvullende beleidsopgave
\end{tabular}

Er wordt vooralsnog aangenomen in de Mariene Strategie (Ministerie van I\&W en LNV, 2018) dat het bestaand beleid gericht op herstel van biodiversiteit (voor zeezoogdieren, vogels, vissen, benthische en pelagische habitats) ook voldoet om de GMT voor het voedselweb te behalen. Wel is er een kennisopgave met betrekking tot de beoordelingsmethode en cumulatie (Ministerie van I\&W en LNV, 2018).

\section{D5 Eutrofiëring}

Het overkoepelend doel voor eutrofiëring is dat door de mens teweeggebrachte eutrofiëring tot een minimum is beperkt, vooral de schadelijke effecten ervan zoals verlies van de biodiversiteit, aantasting van het ecosysteem, en zuurstofgebrek in de bodemwateren. Deze doelstelling is niet bereikt (Tabel 33). Indien de (internationaal) in KRW-verband afgesproken maatregelen ten behoeve

\footnotetext{
${ }^{4}$ zie bijvoorbeeld https://www.ospar.org/work-areas/bdc/ecaprha/about-ecaprha
} 
van de reductie van nutriënten worden uitgevoerd is de inschatting dat de GMT in de jaren na 2020 binnen handbereik ligt. Bovendien is het verder terugdringen van nutriënten ook een van de prioriteiten van de Delta-aanpak waterkwaliteit en zoetwater (o.a. het Deltaplan Agrarisch Waterbeheer en het zesde actieprogramma Nitraatrichtlijn voor de periode 2018 tot en met 2021 (Ministerie van I\&W en LNV (2018). Een aanvullende beleidsopgave boven op het huidige beleid lijkt niet noodzakelijk (Ministerie van I\&W en LNV (2018). Wel is er een kennisopgave met betrekking tot de verhouding fosfaat-stikstof. De concentraties fosfaat in oppervlaktewater zijn namelijk veel sterker gereduceerd dan de concentraties stikstof. Hierdoor is in de kustwateren van de Noordzee een overschot aan stikstof en een tekort aan fosfaat ontstaan, met negatieve gevolgen voor de algengroei en de productiviteit van het Noordzee-ecosysteem (Burson et al., 2016).

Ook zijn een aantal factoren genoemd waardoor effecten van beleid onduidelijk kunnen zijn (Ministerie van I\&W en LNV (2018):

- $\quad$ eutrofiëringsverschijnselen zijn al dermate afgenomen in de afgelopen periode;

- het na-ijlen van stoffen als fosfaat en stikstof uit de waterbodem, lang nadat maatregelen zijn genomen;

- $\quad$ effecten van klimaatverandering;

- toenemende atmosferische depositie (door bronnen op het land, maar ook op zee, zoals de scheepvaart);

- emissiereductie in bovenstrooms gelegen landen.

Tabel 33 Evaluatie huidige toestand eutrofiëring (op basis van het Ministerie van I\&W en LNV, 2018)

\begin{tabular}{|c|c|c|c|c|}
\hline Onderdeel & $\begin{array}{l}\text { GMT } \\
\text { bereikt }\end{array}$ & $\begin{array}{l}\text { Evaluatie } \\
\text { beleid }\end{array}$ & Toelichting & Aanvullende beleidsopgave \\
\hline Eutrofiëring & $x$ & & $\begin{array}{l}\text { Toestand verbetert, maar goede } \\
\text { milieutoestand nog niet } \\
\text { gehaald. }\end{array}$ & $\begin{array}{l}\text { Nee (bestaand beleid voldoet), wel een } \\
\text { kennisopgave met betrekking tot de } \\
\text { verhouding fosfaat-stikstof. }\end{array}$ \\
\hline
\end{tabular}

\section{D6 Bodemintegriteit}

Het overkoepelend doel voor zeebodemintegriteit is drieledig:

- $\quad$ Fysiek verlies van de zeebodem door menselijke activiteiten wordt beperkt om te waarborgen dat de omvang, conditie en globale verspreiding van populaties van de gemeenschap van kenmerkende benthische soorten toeneemt en doelen voor specifieke habitats worden gehaald.

- $\quad$ Fysieke verstoring van de zeebodem door menselijke activiteiten wordt beperkt om te waarborgen dat de omvang, conditie en globale verspreiding van populaties van de gemeenschap van kenmerkende benthische soorten toeneemt en doelen voor specifieke habitats worden gehaald.

- Verbetering van de omvang, conditie en globale verspreiding van populaties van de gemeenschap van benthische soorten.

Deze doelstelling is niet bereikt (Tabel 34). Alleen wat betreft fysieke vernietiging is de doelstelling bereikt maar doelstellingen voor verstoring en de omvang en kwaliteit van benthische habitats zijn nog niet bereikt. De Nederlandse zeebodem is dus nog steeds substantieel verstoord en GMT is niet behaald. Er zijn maatregelen genomen om dit te verbeteren, zoals het aanwijzen van Natura 2000gebieden waarvoor beheerplannen en bodembeschermingsmaatregelen zijn opgesteld. In 2012 is aanvullend beleid ingezet om de GMT voor benthische habitats te behalen. Dit betreft de aanvullende bodembescherming in het Friese Front en Centrale Oestergronden (Ministerie van I\&W en LNV, 2018). In de loop van 2017 is een voorstel gedaan om op drie gebieden met een totale omvang van 2000 $\mathrm{km}^{2}$ geen bodemberoerende visserij toe te staan (zie paragraaf 4.2.4, Figuur 25). Voorstellen om de bodemvisserij in deze gebieden te beperken of te weren zullen aan de Europese Commissie worden voorgelegd om in een Europese verordening om te zetten (Ministerie van I\&W en LNV, 2018). Pas als deze maatregelen worden geïmplementeerd kan er een effect worden verwacht. Er wordt in internationaal (OSPAR) verband gewerkt aan indicatoren die de toestand van de zeebodem in beeld kunnen brengen, zodat op grond hiervan een regionale beoordeling van benthische habitats kan worden gemaakt. Met de nationale benthosindicator (BISI) kan de goede milieutoestand scherper worden omschreven en kan het effect van de (voor)genomen beschermingsmaatregelen worden vastgesteld (Ministerie van I\&W en LNV, 2018). 
Er zijn kennisopgaven met betrekking tot: beoordelingsmethode, cumulatie en hard substraat (Ministerie van I\&W en LNV, 2018).

Tabel 34 Evaluatie huidige toestand zeebodemintegriteit (op basis van het Ministerie van I\&W en LNV, 2018)

$\begin{aligned} & \text { Onderdeel } \\ & \text { Fysieke } \\ & \text { vernietiging van de } \\ & \text { zeebodem }\end{aligned}$
$\begin{aligned} & \text { Fysieke verstoring } \\ & \text { van de zeebodem } \\ & \text { beleid }\end{aligned}$
$\begin{aligned} & \text { Benthische } \\ & \text { Habitats }\end{aligned}$

\section{D7 Hydrografische eigenschappen}

Het overkoepelend doel voor hydrografische eigenschappen is dat het mariene ecosysteem geen negatieve effecten ondervindt als gevolg van permante wijzigingen in de hydrografische eigenschappen als gevolg van menselijke activiteiten. Aangezien grootschalige hydrografische ingrepen uit het verleden (zoals de Deltawerken en de Maasvlakte I) als onomkeerbaar worden beschouwd en dat er de afgelopen periode geen nieuwe grootschalige ingrepen zijn geweest is geconcludeerd dat de doelstelling is bereikt (Tabel 35). Er zijn verder geen kwantitatieve criteria verbonden aan de descriptor waaraan de GMT moet worden voldaan. Wel is er een kennisopgave met betrekking tot de cumulatieve effecten van windenergie op zee, zandwinning en zandsuppletie op hydrografische eigenschappen.

Tabel 35 Evaluatie huidige toestand hydrografische eigenschappen (op basis van het Ministerie van I\&W en LNV, 2018)

\begin{tabular}{|c|c|c|c|c|}
\hline Onderdeel & $\begin{array}{l}\text { GMT } \\
\text { bereikt }\end{array}$ & $\begin{array}{l}\text { Evaluatie } \\
\text { beleid }\end{array}$ & Toelichting & Aanvullende beleidsopgave \\
\hline $\begin{array}{l}\text { Hydrografische } \\
\text { eigenschappen }\end{array}$ & $\sqrt{ }$ & & $\begin{array}{l}\text { Goede milieutoestand gehaald in } \\
2012 \text { en behouden }\end{array}$ & $\begin{array}{l}\text { Nee (bestaand beleid voldoet), } \\
\text { wel een kennisopgave met } \\
\text { betrekking tot de cumulatieve } \\
\text { effecten van windenergie op } \\
\text { zee, zandwinning en } \\
\text { zandsuppletie. }\end{array}$ \\
\hline
\end{tabular}

\section{D8 Vervuilende stoffen}

Het overkoepelend doel voor vervuilende stoffen is dat de concentraties van voor het mariene milieu relevante vervuilende stoffen, gemeten in het meest geëigende compartiment (water, sediment of biota), lager zijn dan de concentraties waarbij negatieve effecten kunnen optreden of laten een dalende trend zien. De gezondheid van de soorten wordt niet geschaad door vervuilende stoffen. De doelstelling is nog niet bereikt (Tabel 36). Er zijn al veel maatregelen getroffen waardoor voor de meeste stoffen (uitgezonderd de persistente stoffen die nog lang in het milieu aanwezig blijven) de GMT in de jaren na 2020 gehaald zullen worden (Ministerie van I\&W en LNV, 2018). Om deze reden is geen aanvullende beleidsopgave nodig boven op het huidige beleid en blijft het preventiebeleid (conform de KRW) van toepassing (Ministerie van I\&W en LNV, 2018). Er is een kennisopgave met betrekking tot koper: koperconcentraties zijn nog niet opgenomen in het KRM monitoringprogramma, maar naar verwachting zal dit uiterlijk in 2020 gebeuren. Ook de aanwezigheid van geneesmiddelen en andere nieuwe microverontreinigingen in het oppervlaktewater vraagt de komende jaren extra aandacht en is als kennisopgave vastgelegd. 
Tabel 36 Evaluatie huidige toestand vervuilende stoffen (op basis van het Ministerie van I\&W en LNV, 2018)

\begin{tabular}{lll} 
Onderdeel & $\begin{array}{l}\text { GMT } \\
\text { bereikt } \\
\text { beleid }\end{array}$ & \multicolumn{1}{c}{ Toelichting }
\end{tabular}

\section{D9 Vervuilende stoffen in vis}

Het overkoepelend doel voor vervuilende stoffen in vis is dat de niveaus van vervuilende stoffen (waaronder PAK's, dioxinen en zware metalen) in vis en visproducten uit de Noordzee de in de EU verordening EG 1881/2006 vastgestelde maximumgehalten niet overschrijden. Deze doelstelling is bereikt en er is geen aanvullend beleid nodig (Tabel 37).

Tabel 37 Evaluatie huidige toestand vervuilende stoffen in vis (op basis van het Ministerie van I\&W en $L N V, 2018)$

\begin{tabular}{|c|c|c|c|c|}
\hline Onderdeel & $\begin{array}{l}\text { GMT } \\
\text { bereikt }\end{array}$ & $\begin{array}{l}\text { Evaluatie } \\
\text { beleid }\end{array}$ & Toelichting & Aanvullende beleidsopgave \\
\hline
\end{tabular}

\section{D10 Zwerfvuil}

Het overkoepelend doel voor zwerfvuil is:

- de hoeveelheid zwerfvuil op zee neemt in de loop van de tijd af;

- de hoeveelheid microafval op zee neemt op lange termijn af; en

- de hoeveelheid door zeedieren opgenomen afval en microafval ligt op een niveau dat niet schadelijk is voor de gezondheid van de desbetreffende soorten.

De doelstelling is nog niet bereikt en deels onbekend (Tabel 38). Er is dan ook een aanvullende beleidsopgave (zie paragraaf 4.3.7) en een kennisopgave vastgelegd. De kennisopgave heeft betrekking op rivierafval, microplastics en de effecten op het mariene ecosysteem. Er is steeds meer bekend over de bronnen van (micro)plastics en over de aanwezigheid en effecten van (micro)plastics in zee (Besseling, 2018; Deltares, 2013; GESAMP, 2015; Leslie et al., 2017). Rivieren zijn een grote bron van zwerfvuil. Over de exacte omvang van deze bronnen is nog weinig bekend, maar onderzoek geeft al wel een eerste indicatie van de omvang van de aanvoer vanuit de Nederlandse rivieren (Deltares, 2013). Er blijft meer onderzoek nodig naar rivierafval en de aanwezigheid en de milieueffecten van microplastics.

Tabel 38 Evaluatie huidige toestand zwerfvuil (op basis van het Ministerie van I\&W en LNV, 2018)

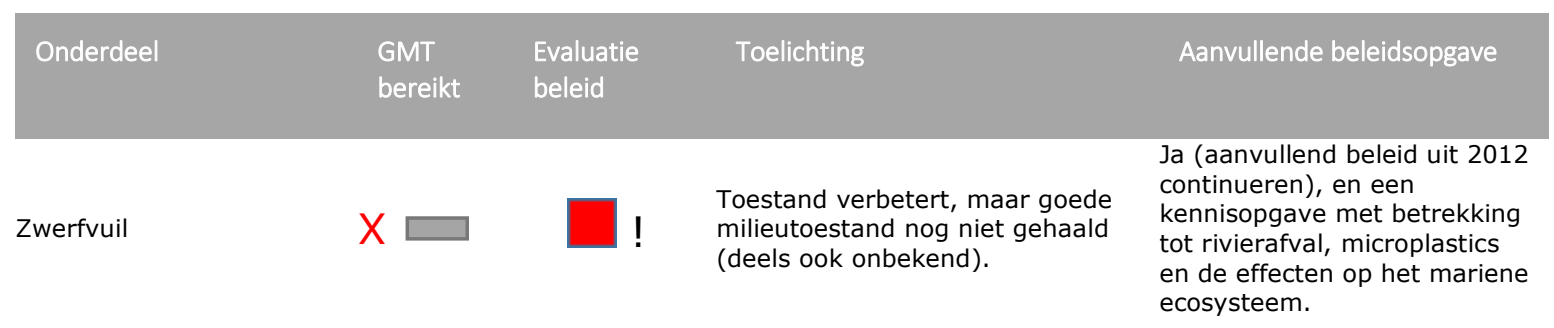

\section{D11 Onderwatergeluid}

Descriptor D11 omvat de toevoer van energie, waaronder onderwatergeluid. De Nederlandse KRM richt zich echter uitsluitend op onderwatergeluid. Het overkoepelend doel voor onderwatergeluid is:

- Impulsgeluid: ruimtelijke spreiding, tijdsduur en geluidsniveaus van luide impulsieve bronnen zijn zodanig dat directe en indirecte effecten van luid impulsieve geluid niet de gunstige staat van instandhouding van soorten in gevaar kan brengen. 
- $\quad$ Continu geluid: ruimtelijke spreiding, tijdsduur en niveaus van achtergrondgeluid is zodanig dat dit niet de gunstige staat van instandhouding van soorten in gevaar kan brengen.

Het is onbekend of de doelstelling is bereikt (Tabel 39). Voor continu geluid is het nog niet mogelijk om een kwantitatieve omschrijving van de goede milieutoestand op te stellen, omdat gegevens over niveaus en trends van continu geluid (ook internationaal) nog niet beschikbaar zijn. Er is een kennisopgave met betrekking tot cumulatie en continu geluid.

Tabel 39 Evaluatie huidige toestand onderwatergeluid (op basis van het Ministerie van I\&W en LNV, 2018)

$\begin{array}{ll}\text { Onderdeel } & \begin{array}{l}\text { GMT } \\ \text { bereikt } \\ \text { beleid }\end{array}\end{array}$

\subsection{Relevantie voor beheer}

\subsubsection{Risico versus status}

Een mogelijke wijze om inzicht te geven in de prioriteiten voor beheer ter verbetering van de toestand van de Noordzee is door het risico op impact per descriptor (op basis van de CEA) te combineren met de huidige GMT status (op basis van de geactualiseerde Mariene Strategie deel 1 (Ministerie van I\&W en LNV, 2018)), zie Figuur 57.

Voor wat betreft de GMT-status zijn er maar twee mogelijkheden: indien voor een criterium de GMT is gehaald is de status goed (1) terwijl de status slecht (0) is indien de GMT niet is gehaald of onbekend is. Voor deze uitwerking is vooralsnog gekozen om per criterium een binaire score aan te houden.

- $\quad$ Per descriptor zijn er meerdere criteria/indicatoren waarbij de status per descriptor wordt gemiddeld.

- Het risico is uitgedrukt als totaal gesommeerd risico.

- De risico scores zijn vervolgens verdeeld in hoog en laag risico door de schaal in tweeën te delen. Hierbij moet worden opgemerkt dat dit een arbitraire keuze is en geen daadwerkelijk onderscheid maakt tussen wel of geen acceptabel risico. Het is hier alleen bedoeld om te kunnen prioriteren.

In de figuren zijn daardoor 4 kwadranten zichtbaar, die de status in combinatie met het risico aangeven: status goed - risico laag; status goed - risico hoog; status slecht - risico laag; status slecht - risico hoog. Deze kwadranten informeren het beheer met betrekking tot de prioriteiten, waarbij bijvoorbeeld kan worden gesteld dat:

- $\quad$ Status goed - risico laag (groen):

Lage prioriteit. Geen actie, alleen monitoring

- $\quad$ Status goed - risico hoog (geel):

Gemiddelde prioriteit. Monitoring, 'hand aan de kraan-principe' en onderzoek naar risico's;

- Status slecht - risico laag (geel):

Gemiddelde prioriteit. Vooral onderzoek naar risico's en oorzaken slechte status en (mogelijk) herstelmaatregelen;

- $\quad$ Status slecht - risico hoog (rood):

Hoge prioriteit. Maximale inzet van maatregelen en nader onderzoek naar risico's en oorzaken slechte status. 
Hoge prioriteit: Visserij, zwerfvuil en vervuilende stoffen zijn de drukfactoren met het hoogste risico op het Noordzee ecosysteem. De GMT voor deze drukfactoren is tevens nog niet bereikt. Voor visserij en vervuiling wordt aangenomen dat het bestaand beleid voldoet om de GMT te behalen. Er zijn beleidsmaatregelen genomen waardoor in de toekomst nog verbetering wordt verwacht (herstel visbestanden en reductie van verontreinigende stoffen). Wel is er voor vervuilende stoffen een kennisopgave met betrekking tot opkomende stoffen en koper. Voor zwerfvuil voldoet het huidig beleid (mogelijk) niet en is voortzetting van het aanvullend beleid uit 2012 noodzakelijk (zie paragraaf 4.3.7). Ook is er een kennisopgave met betrekking tot rivierafval, microplastics en de effecten op het mariene ecosysteem vastgesteld. Tezamen met deze drukfactoren geldt dat de cumulatieve effecten van alle menselijke activiteiten tezamen een hoog risico veroorzaken en ertoe geleid hebben dat de ecosysteem componenten de GMT niet bereikt hebben.

Gemiddelde prioriteit: In termen van het behalen van GMT scoren de zeezoogdieren het hoogst van alle ecosysteem componenten. Er is een verbetering van de toestand van zeezoogdieren waargenomen en de populatieomvang van de grijze- en gewone zeehond en bruinvis voldoen aan de gunstige referentiewaarde vanuit de Habitatrichtlijn. Toch is de risico score relatief hoog (Figuur 57) en voldoet het bestaand beleid mogelijk niet om de GMT te bereiken. De kans bestaat namelijk dat de GMT verder onder druk komt te staan als gevolg van de Nederlandse en buitenlandse opgaven voor de ontwikkeling van duurzame energie op zee. Daarom is er een kennisopgave met betrekking tot cumulatie. Voor onderwatergeluid zijn er nog geen criteria die aan de GMT voldoen vanwege het ontbreken van grenswaarden en voldoende meetgegevens. Vandaar de relatief slechte status van deze descriptor.

Lage prioriteit: Eutrofiëring en niet-inheemse soorten (exoten) scoren relatief hoog qua GMT. Het bestaand beleid voldoet om de GMT van deze drukfactoren te bereiken. Wel is er een kennisopgave met betrekking tot de toename van hard substraat (exoten) en de verhouding fosfaat-stikstof (eutrofiëring)- zie paragraaf 4.3 en 5.2 . 


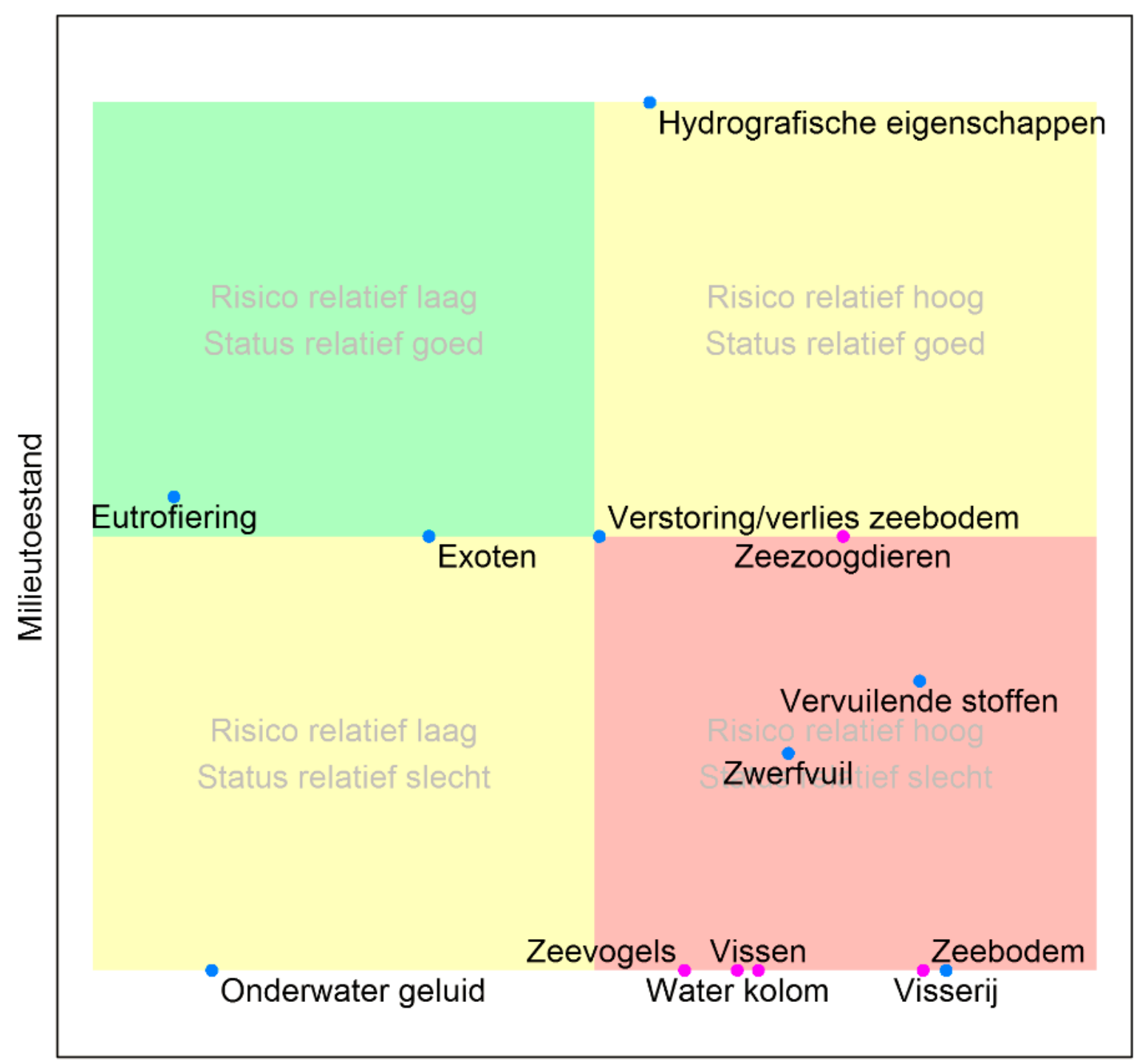

\section{Risico score}

Figuur 57 Prioriteiten voor beheer op basis van de weergave van de status (Status goed: GMT voor meer dan de helft van de criteria behaald; Status slecht: GMT voor minder dan de helft van de criteria behaald) en de risico score (het relatieve risico op impact door gebruik te maken van de CEA), waarbij het gesommeerde totaal risico is weergegeven per ecosysteem onderdeel (roze stippen) en drukfactor (blauwe stippen). Er zijn 4 kwadranten zichtbaar, die de status in combinatie met het risico aangeven: status goed - risico laag (groene vlak links boven); status goed - risico hoog (gele vlak rechts boven); status slecht - risico laag (gele vlak links onder); status slecht - risico hoog (rode vlak rechts onder).

\subsubsection{Belangrijkste drukfactoren en activiteiten}

Voor de weergave van de belangrijkste drukfactoren (Figuur 587) en activiteiten (Figuur 598) in deze paragraaf is gebruik gemaakt van de risico scores die middels een CEA zijn geschat voor de internationale Noordzee. Hierbij moet worden opgemerkt dat er een mogelijk artefact in de analyse is dat door betere modellen (zie ModellenVisie Noordzee) waarschijnlijk geëlimineerd kan worden. Er zijn alvast enige aanpassingen gedaan om de risicoschatting beter geschikt te maken voor dit rapport (o.a. meer specifiek gericht op de Nederlandse Noordzee met betrekking tot de ruimtelijke omvang en intensiteit). De resultaten moeten daarom met enige voorzichtigheid worden beschouwd.

Vervuilende stoffen, onttrekking van soorten en zwerfvuil zijn de drukfactoren die het meest bijdragen aan de cumulatieve effecten op het Noordzee ecosysteem (Figuur 587). Visserij (demersaal, vaste 
vistuigen en pelagisch) en scheepvaart behoren tot de activiteiten die het meeste bijdragen aan de cumulatieve effecten (Figuur 598).

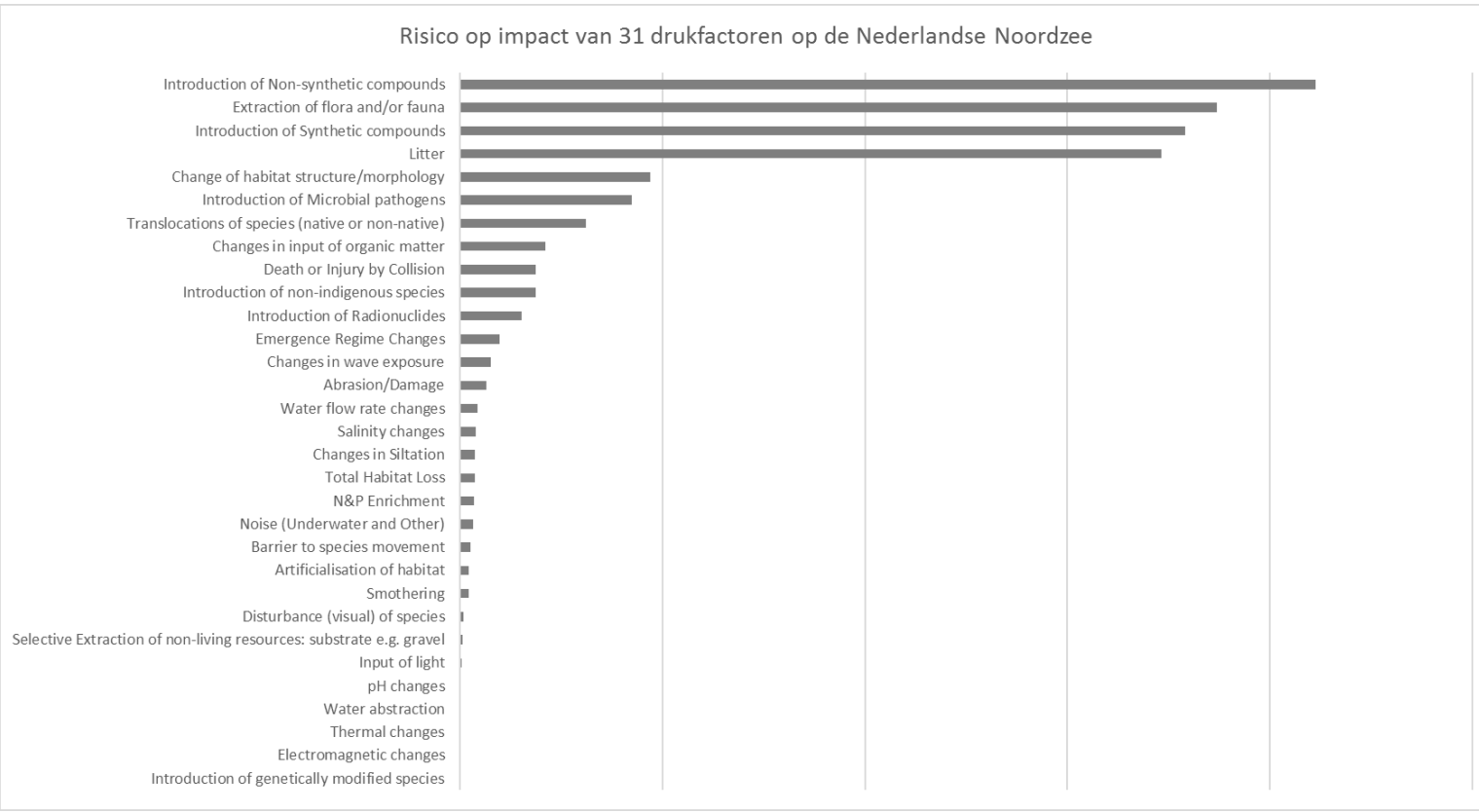

Figuur 58 Relatieve bijdrage van drukfactoren aan de cumulatieve effecten op de Nederlandse Noordzee. Vanwege de uitwerking van de huidige CEA moet dit gezien worden als een ranglijst. De verhouding tussen de lengte van de staven is niet relevant.

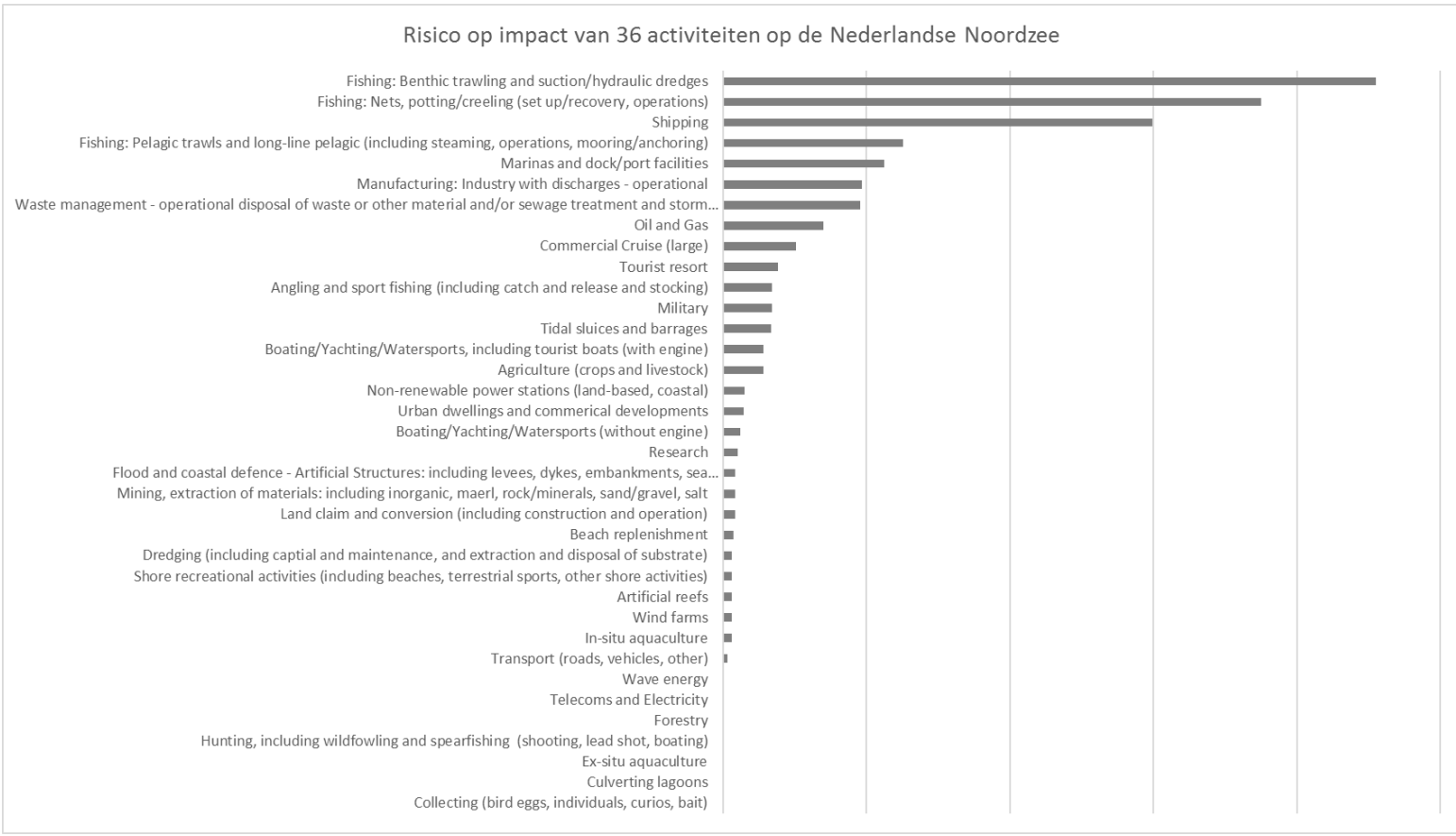

Figuur 59 Relatieve bijdrage van activiteiten aan de cumulatieve effecten op de Nederlandse Noordzee. Vanwege de uitwerking van de huidige CEA moet dit gezien worden als een ranglijst. De verhouding tussen de lengte van de staven is niet relevant. 


\section{Evaluatie beleid en beheer}

Het huidige voor de Noordzee relevante beleid en beheer wordt hier geëvalueerd in relatie tot de beleidsdoelstellingen. Daartoe wordt achtereenvolgens de toestandbeoordeling van de KRM nog eens samengevat (paragraaf 6.1), het KRM Programma van Maatregelen beoordeeld (paragraaf 6.2), een opsomming gegeven van alle kennisvragen die in de KRM zijn gesteld (paragraaf 6.3) en tenslotte wordt in paragraaf 6.4 de Noordzee geëvalueerd in relatie tot de beleidsdoelen voor de leefomgeving.

\subsection{Beoordeling KRM}

De belangrijkste bevindingen van de Nederlandse beoordeling 2018 voor de KRM zijn (Ministerie van I\&W en Ministerie van LNV, 2018):

- $\quad$ De goede milieutoestand is niet behaald maar verbeteringen zijn zichtbaar.

- Bestaand beleid resulteert in een aanzienlijke afname van de vervuiling van het mariene milieu, in groei van commerciële visbestanden, in toename van het aantal zeezoogdieren en in afname van het aantal nieuwe niet-inheemse soorten.

- Voortzetting van het bestaand beleid moet wel gepaard gaan met de aanpak van kennisleemten en onzekerheden.

- $\quad$ Toekomstige ontwikkelingen zoals de aanleg van nieuwe windparken en klimaatverandering kunnen de milieutoestand beïnvloeden. Windparken bieden daarentegen mogelijk ook kansen voor ecosysteemherstel.

- Inspanningen om de goede milieutoestand te bereiken, zijn vooral - of zelfs uitsluitend effectief wanneer ze het resultaat zijn van internationale samenwerking en afstemming.

Als onderdeel van de KRM heeft Nederland een reeks milieudoelen vastgesteld om de kloof te overbruggen tussen de huidige situatie van de Noordzee en de gewenste situatie (GMT) in 2020. Deze milieudoelen zijn per onderdeel beschreven in Hoofdstuk 4. Voor acht van de elf KRM Descriptoren voldoet het huidig beleid waarschijnlijk om de doelstellingen en daarmee de GMT te bereiken (zie Hoofdstuk 4 en 5). Voor D1 (biodiversiteit), D6 (zeebodemintegriteit) en D10 (zwerfvuil) voldoet het huidig beleid (mogelijk) niet en is aanvullend beleid noodzakelijk (Figuur 6060). 


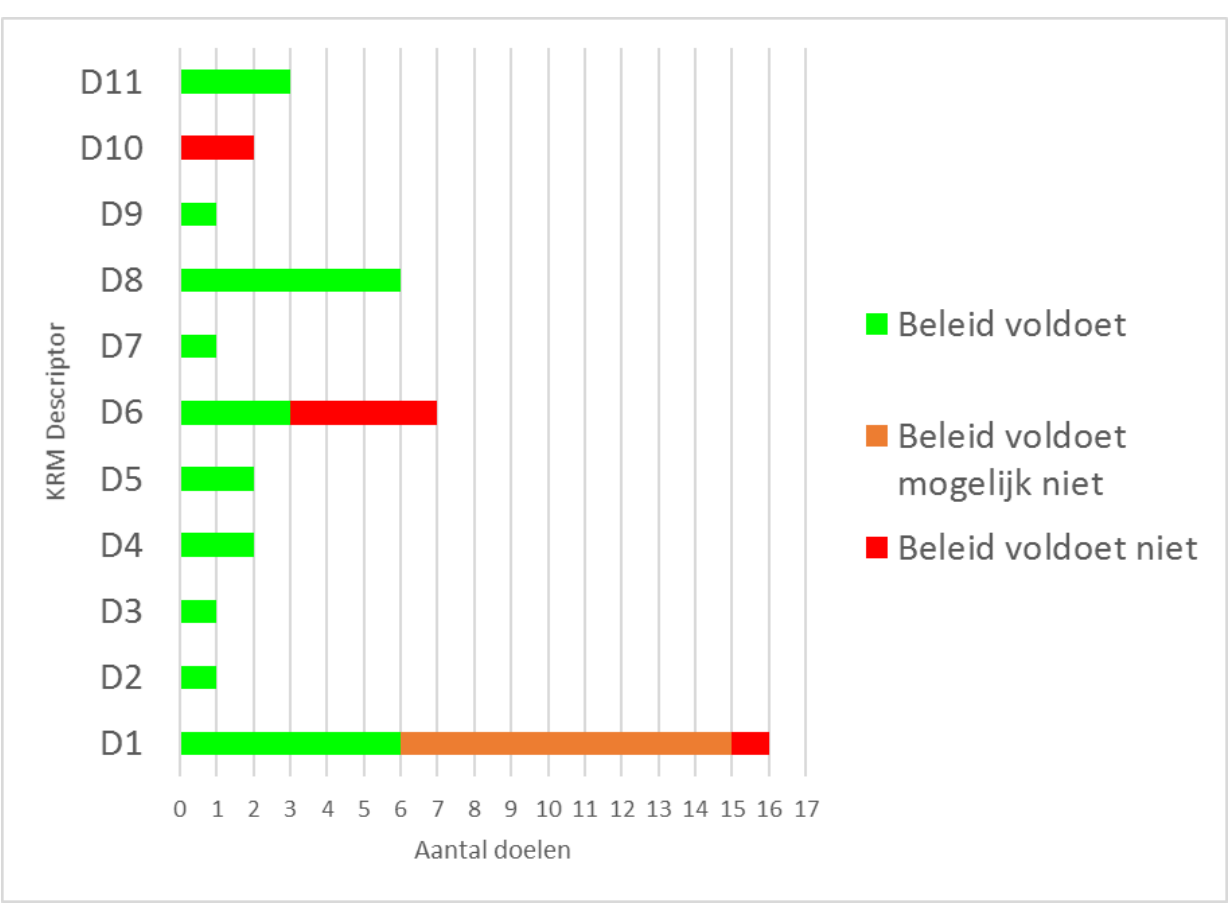

Figuur 60 Beleidsevaluatie per KRM Descriptor en milieudoelen (gebaseerd op Ministerie van I\&W en LNV, 2018). D1 Biodiversiteit; D2 Niet-inheemse soorten; D3 Commerciële visbestanden; D4 Voedselweb; D5 Eutrofiering; D6 Bodemintegriteit; D7 Hydrografische eigenschappen; D8 Vervuilende stoffen; D9 Vervuilende stoffen in vis; D10 Zwerfvuil; D11 Energietoevoer, o.m. onderwatergeluid.

\subsection{Programma van Maatregelen}

Het meest recente Programma van Maatregelen is door Piet et al (2014) geëvalueerd op grond van de mate waarin al de potentiële effectketens voor de Nederlandse Noordzee zijn afgedekt door het voorgestelde programma van maatregelen. De analyse van Piet et al. (2014) laat zien dat het risico op het niet behalen van de KRM milieudoelen potentieel geheel afgedekt kan worden door het maatregelenpakket. Maar de analyse laat ook zien dat dit nog geen garantie inhoudt dat daarmee de doelen gerealiseerd worden omdat deze evaluatie niet beoordeelt of de mate waarin de verschillende maatregelen uitgevoerd worden, afdoende is. Verder wordt genoemd dat de zeggingskracht van de CEA enigszins beperkt wordt door enkele zeer generieke maatregelen (bijvoorbeeld "implementatie OSPAR-lijst bedreigde diersoorten en habitats"). Doordat vrijwel alle ecosysteem componenten (alleen waterkolom niet) deze kenmerken omvat, en daarmee dus de meeste effectketens erin besloten liggen, resulteert een dergelijke generieke maatregel ook in een grote potentiele reductie van de cumulatieve effecten (Piet et al., 2014). Additionele analyses die de vijf meest generieke maatregelen uitsluiten en dus alleen de meest specifieke maatregelen meenemen, laten een meer genuanceerd beeld zien van de mate waarin de cumulatieve effecten op het Noordzee ecosysteem door het KRM Programma van Maatregelen afgedekt zijn.

De top 5 meest generieke maatregelen, die het hoogste aantal effect-ketens afdekt, zijn (Piet et al., 2014):

- Implementatie OSPAR-lijst bedreigde diersoorten en habitats (868 ketens, 92\%)

- Aanmelding beschermde gebieden OSPAR (782 ketens, 83\%)

- Uitbreiding werkingsgebied Nb-wet en Ff-wet (501 ketens, 53\%)

- Regulering van andere activiteiten in de kustzone (474 ketens, 50\%)

- Beoordeling van en compensatie bij (grootschalige) ingrepen (322 ketens, 34\%) 
Wanneer gekeken wordt naar de totale risico reductie (TR), ziet de top 5 er als volgt uit (Piet et al., 2014):

- Implementatie OSPAR-lijst bedreigde diersoorten en habitats (TR=100\%)

- Aanmelding beschermde gebieden OSPAR (TR=92\%)

- $\quad$ Regulering van andere activiteiten in de kustzone (TR=70\%)

- $\quad$ Uitbreiding werkingsgebied $\mathrm{Nb}$-wet en Ff-wet $(\mathrm{TR}=68 \%)$

- Voorbereiding, samenwerking en coördinatie bij rampenbestrijding en incidentenaanpak op zee $(T R=56 \%)$

De beoordeling van de huidige milieutoestand in 2018 heeft niet geleid tot andere of aanvullende speerpunten voor het beleid voor de periode tot 2024. Het kabinet continueert daarom de bestaande (aanvullende) beleidsopgaven (Ministerie van I\&W en LNV, 2018). Daarbij zijn wel enkele aandachtspunten geformuleerd:

- de effectiviteit van het bestaande beleid (onder andere voor vogels);

- $\quad$ het realiseren van de opgave voor duurzame energie op zee en;

- de ontwikkeling van de Strategische Agenda Noordzee 2030.

Deze aandachtspunten zijn verder uitgewerkt in de kennisprogrammering, zie paragraaf 6.3.

\subsection{Kennisvragen}

Voorafgaand aan de actualisatie van het KRM monitoringprogramma (15 juli 2020) en het KRM programma van maatregelen (eind 2021) is het belangrijk dat de voornaamste kennishiaten ingevuld zijn. De prioriteiten voor de kennisprogrammering zijn (Ministerie van I\&W en LNV, 2018):

- Bijdrage van nieuwe windparken en andere menselijke activiteiten aan de cumulatieve effecten op het Noordzee ecosysteem. Voor windparken zijn dat vooral de effecten op zeevogels en de gevolgen van onderwatergeluid tijdens de bouwfase voor zeezoogdieren. Bij andere activiteiten gaat het vooral om de effecten van de (verplaatsing van) visserij op zeezoogdieren, haaien en roggen.

- Bijdrage van verhoogde zandwinning en strandsuppleties aan de cumulatieve effecten op het bodemleven.

- Mogelijkheden voor actief herstel van (verdwenen) biogene riffen, zoals schelpenbanken, onder andere in windparken.

- Het broedsucces van zeevogels en factoren die hierop van invloed kunnen zijn.

- Beoordelingsmethoden voor benthische en pelagische habitats.

- Relaties in het voedselweb in de Noordzee, gevormd door een netwerk van zeebodemflora en fauna (benthos), kleine en grote vissen en zeezoogdieren.

- Gevolgen van verzuring.

- De fosfaat-stikstofverhouding.

- Microplastics, koper, medicijnresten en andere (opkomende) stoffen.

- Beoordelingskader voor samenhangend en representatief netwerk van beschermde gebieden op zee.

De ontwikkelde kennis kan leiden tot bijstelling van de beleidsopgaven. Dit wordt vervolgens geagendeerd in kader van de Strategische Agenda Noordzee 2030 (Ministerie van I\&W en LNV, 2018).

\subsection{Beleidsdoelen voor de leefomgeving}

Het PBL heeft in de Balans van de leefomgeving 2018 geëvalueerd wat de effecten zijn van het beleid voor natuur. Daarbij zijn 6 beleidsdoelen gekozen (zie Tabel 40). Daarvoor is nagegaan in hoeverre deze zijn behaald of mogelijk worden behaald, en of de overheid nog meer kan doen om de beleidsdoelen alsnog te behalen. De mate waarin beleidsdoelen naar verwachting tijdig worden gehaald werd met zgn. stoplichtcodering aangegeven. In onderstaande tabel is het resultaat hiervan overgenomen, waaraan wij in deze notitie ook het resultaat voor de milieutoestand hebben toegevoegd met soortgelijke kleurcodering (stoplicht), zie voor een verklaring van de symbolen paragraaf 5.1 . 
Tabel 40 Evaluatie van beleidsdoelen Natuur

\begin{tabular}{|l|c|c|}
\hline Beleidsdoel Natuur van PBL (onderwerp) & Doel bereikt? & Beleidseffectiviteit \\
\hline Natuurnetwerk Nederland (2027) & $\mathrm{X}$ & \\
\hline Milieucondities natuur & $\mathrm{X}$ & \\
\hline Rode Lijst van bedreigde soorten & $\mathrm{X}$ & \\
\hline Staat van instandhouding EU-soorten en habitattypen (2020) & $\mathrm{X}$ & \\
\hline Ecosysteemkwaliteit land en water & $\mathrm{X}$ & \\
\hline Ecologische barrières door aanleg nationale infrastructuur & $\mathrm{X}$ & \\
\hline
\end{tabular}

De Noordzee is echter geen onderdeel van ieder van deze beleidsdoelen en wanneer dit wel zo is, dan is deze geïntegreerd met het landelijk gebied (land en zoetwater). We hebben dit hieronder per beleidsdoel nader geanalyseerd door een aantal stappen te doorlopen. Uiteindelijk willen we hiermee duidelijk krijgen per beleidsdoel of er meer aandacht aan de toestand en ontwikkeling van de natuur in de Noordzee zou kunnen en moeten worden gegeven en op welke wijze. Er worden daarvoor enkele suggesties gedaan.

\section{Natuurnetwerk Nederland}

\begin{tabular}{|c|c|}
\hline $\begin{array}{l}\text { Beleidsdoel Natuur van } \\
\text { PBL }\end{array}$ & Natuurnetwerk Nederland (2027) \\
\hline oelstelling & Tussen 2011 en 2027 minimaal 80.000 hectare nieuwe natuur te realiseren \\
\hline $\begin{array}{l}\text { Resultaat Balans } \\
018\end{array}$ & $\begin{array}{l}\text { Met de huidige provinciale plannen is ruim in de gestelde opgave van } 80.000 \\
\text { hectare voorzien, maar de verwachting is dat verwerving en functiewijziging van } \\
\text { gronden voor nieuwe natuur nog lastig zullen worden, onder andere vanwege de } \\
\text { afhankelijkheid van medewerking van grondeigenaren. }\end{array}$ \\
\hline $\begin{array}{l}\text { Behalen van } \\
\text { doelstelling in balans } \\
2018\end{array}$ & $\begin{array}{l}\text { Geraamde ontwikkeling ligt rond het doel, beleid zou robuust gemaakt kunnen } \\
\text { worden voor tegenvallers }\end{array}$ \\
\hline $\begin{array}{l}\text { Aandacht voor } \\
\text { Noordzee }\end{array}$ & $\begin{array}{l}\text { Marginaal; beoordeling alleen voor landnatuur; Alle grote wateren, waaronder } \\
\text { Waddenzee, IJsselmeer, Zeeuwse delta en Noordzee aangewezen als onderdeel } \\
\text { van het NNN. Op de Noordzee zijn } 6 \text { Natura2000-gebieden aangewezen: de } \\
\text { Voordelta en de Noordzeekustzone (VHR-gebieden), de Vlakte van de Raan, de } \\
\text { Doggersbank en de Klaverbank (HR-gebieden), en het Friese Front (VR-gebied). } \\
\text { Voor deze gebieden zijn (of worden) beheerplannen opgesteld, waarin is } \\
\text { aangegeven op welke manier activiteiten niet ten koste gaan van de natuur of } \\
\text { daarin zelfs mogelijk verbetering kunnen brengen. Andere waardevolle gebieden } \\
\text { in de Noordzee zijn (de bodems van) het Friese Front, de Centrale } \\
\text { Oestergronden en de Bruine Bank. Het instellen van een samenhangend en } \\
\text { representatief netwerk van beschermde gebieden op de zee is één van de doelen } \\
\text { van de KRM. In het kader van de KRM is voor een areaal van } 2000 \text { km² van het } \\
\text { Friese Front en Centrale Oestergronden de status 'bodembeschermingsgebied' } \\
\text { voorgesteld. Het is nog niet bekend wanneer de Europese Commissie hierover } \\
\text { een besluit neemt, en wat de concrete maatregelen zullen zijn. Het besluit over } \\
\text { de mogelijke aanwijzing van de Bruine Bank als Vogelrichtlijngebied wordt in de } \\
\text { komende periode genomen. Tot die tijd wordt de status van het gebied als } \\
\text { mogelijk ecologisch waardevol' gehandhaafd. }\end{array}$ \\
\hline $\begin{array}{l}\text { Suggestie voor extra } \\
\text { ditwerking voor } \\
\text { Noordzee }\end{array}$ & $\begin{array}{l}\text { Wat is het doel voor omvang Natura } 2000 \text {-gebieden op de Noordzee? Is er met } \\
\text { de huidige Natura } 2000 \text {-gebeiden op de Noordzee voldaan aan de doelstelling } \\
\text { voor oppervlakte van marine habitattypen, zoals zandbanken (H1110b en c) en } \\
\text { riffen (H1170)? Voor de bescherming van de biodiversiteit dient minimaal } 10 \% \\
\text { van het oppervlak van de Noordzee te worden aangewezen (Biodiversity } \\
\text { Directive). Hoe verhoudt het beheer voor N2000 gebieden zich tot de beoogde }\end{array}$ \\
\hline
\end{tabular}




\section{Milieucondities natuur}

\begin{tabular}{|c|c|}
\hline $\begin{array}{l}\text { Beleidsdoel Natuur van } \\
\text { PBL }\end{array}$ & Milieucondities natuur \\
\hline Doelstelling & $\begin{array}{l}\text { Verbetering van bodem-, water- en luchtcondities om biodiversiteit te herstellen } \\
\text { en te behouden. }\end{array}$ \\
\hline $\begin{array}{l}\text { Resultaat Balans } \\
2018\end{array}$ & $\begin{array}{l}\text { In grote delen van de Nederlandse landnatuur zijn milieu- en ruimtelijke } \\
\text { condities nog matig of slecht voor duurzaam voorkomen van soorten en } \\
\text { ecosystemen. Dit is gebaseerd op resultaten voor stikstofdepositie, zuurgraad, } \\
\text { grondwaterstand, ruimtelijke conditie. }\end{array}$ \\
\hline $\begin{array}{l}\text { Behalen van } \\
\text { doelstelling in balans } \\
2018\end{array}$ & $\begin{array}{l}\text { Geraamde ontwikkeling leidt waarschijnlijk niet tot het halen van het doel, } \\
\text { vraagt fundamentele herziening van de huidige aanpak door andere } \\
\text { beleidsinstrumenten in te zetten of door doelen aan te passen }\end{array}$ \\
\hline $\begin{array}{l}\text { Aandacht voor } \\
\text { Noordzee }\end{array}$ & Nee; alleen landnatuur \\
\hline $\begin{array}{l}\text { Suggestie voor extra } \\
\text { uitwerking voor } \\
\text { Noordzee }\end{array}$ & $\begin{array}{l}\text { Verschillende activiteiten op zee hebben een impact op de zeebodem (verlies of } \\
\text { verstoring). Mitigatie van die impact kan leiden tot verbetering. Daarnaast kan } \\
\text { er gekozen worden extra natuurwaarde te creëren met die activiteiten } \\
\text { (bijvoorbeeld extra hard substraat in windmolenparken die biodiversiteit } \\
\text { verbeteren). Eutrofiering (N, P) op Noordzee is beoordeeld, want dit is een } \\
\text { descriptor (D5) met criteria en indicatoren. Zie daarvoor paragraaf } 4.3 .3 \text { en } 5.2 \\
\text { in het voorliggende rapport. Zuurgraad(verandering) en de effecten ervan kan } \\
\text { nog nader worden onderzocht voor de Noordzee. }\end{array}$ \\
\hline
\end{tabular}

Rode Lijst

\begin{tabular}{|l|l|}
\hline $\begin{array}{l}\text { Beleidsdoel Natuur } \\
\text { van PBL }\end{array}$ & Rode Lijst van bedreigde soorten \\
\hline Doelstelling & Rode Lijsten van bedreigde soorten worden korter en 'minder rood' . \\
\hline $\begin{array}{l}\text { Resultaat Balans } \\
2018\end{array}$ & $\begin{array}{l}\text { Ongeveer een derde van alle soorten is bedreigd. In } 2017 \text { is het aantal bedreigde } \\
\text { soorten licht gestegen. }\end{array}$ \\
\hline $\begin{array}{l}\text { Behalen van } \\
\text { doelstelling in } \\
\text { balans 2018 }\end{array}$ & $\begin{array}{l}\text { Ontwikkeling leidt waarschijnlijk niet tot het halen van het doel, en vraagt } \\
\text { fundamentele herziening van de huidige aanpak door andere beleidsinstrumenten } \\
\text { in te zetten of door doelen aan te passen }\end{array}$ \\
\hline $\begin{array}{l}\text { Aandacht voor } \\
\text { Noordzee }\end{array}$ & $\begin{array}{l}\text { la alleen bij (kustgebonden) broedvogels en zoogdieren, maar die dan over NL } \\
\text { geïntegreerd. }\end{array}$ \\
\hline $\begin{array}{l}\text { Suggestie voor } \\
\text { extra uitwerking } \\
\text { voor Noordzee }\end{array}$ & $\begin{array}{l}\text { Rode lijst doelstelling van het PBL kan nader worden onderzocht op het } \\
\text { voorkomen van zeevissen, zeezoogdieren en zeevogels die de Noordzee als } \\
\text { leefgebied hebben. Er staan 26 zoutwatervissoorten op de Nederlandse Rode Lijst } \\
\text { die is gebaseerd op het achtergrond document dat is opgesteld door Tien et al. } \\
\text { (2016). Vier zoogdiersoorten van de Noordzee staan op de Nederlandse Rode } \\
\text { Lijst met in totaal 24 zoogdiersoorten (Zoogdiervereniging VZZ, 2007). Er staan 8 } \\
\text { broedvogelsoorten en } 2 \text { niet-broedvogelsoorten van de Noordzee op de Rode Lijst } \\
\text { met vogelsoorten (Van Kleunen et al., 2016). }\end{array}$ \\
\hline
\end{tabular}

Vogel- en Habitatrichtlijn

\begin{tabular}{|l|l|}
\hline $\begin{array}{l}\text { Beleidsdoel Natuur } \\
\text { van PBL }\end{array}$ & Staat van instandhouding EU-soorten en habitattypen (2020) \\
\hline Doelstelling & $\begin{array}{l}\text { Het lange termijndoel van de Europese Vogel- en Habitatrichtlijnen is een gunstige } \\
\text { staat van instandhouding van soorten en habitattypen. Daarnaast is vanuit de }\end{array}$ \\
\hline
\end{tabular}




\begin{tabular}{|c|c|}
\hline & $\begin{array}{l}\text { Europese Biodiversiteitsstrategie de doelstelling voor de korte termijn (2020) dat } \\
\text { de achteruitgang van soorten en habitattypen wordt gestopt en hun staat } \\
\text { significant verbetert. Doel van de Europese Vogel- en Habitatrichtlijnen is het } \\
\text { bereiken van een gunstige staat van instandhouding van soorten en habitattypen }\end{array}$ \\
\hline $\begin{array}{l}\text { Resultaat Balans } \\
2018\end{array}$ & $\begin{array}{l}\text { In de periode } 2007 \text { t/m } 2012 \text { had in Nederland } 4 \% \text { van de habitattypen een } \\
\text { gunstige staat van instandhouding. Van de habitatrichtlijnsoorten heeft } 23 \% \text { een } \\
\text { gunstige staat van instandhouding. } 10 \% \text { van de habitattypen met een ongunstige } \\
\text { staat van instandhouding laat verbetering zien, terwijl in bijna } 27 \% \text { de status } \\
\text { verslechterd is. Voor habitatrichtlijnsoorten met een ongunstige staat laat } \\
\text { Nederland de sterkste verbeterende trend in staat van instandhouding zien. Voor } \\
\text { Nederland laten populatietrends over } 2001-2012 \text { een wisselend beeld zien: } 39 \% \\
\text { van de broedvogels en } 37 \% \text { van de overwinterende populaties laten een } \\
\text { verbetering zien. Daar staat tegenover dat } 37 \% \text { van de broedvogels en } 21 \% \text { van } \\
\text { de overwinterende populaties juist een afnemende trend vertonen. }\end{array}$ \\
\hline $\begin{array}{l}\text { Behalen van } \\
\text { doelstelling in } \\
\text { balans } 2018 \\
\end{array}$ & $\begin{array}{l}\text { Geraamde ontwikkeling leidt waarschijnlijk niet tot het halen van het doel, vraagt } \\
\text { fundamentele herziening van de huidige aanpak door andere beleidsinstrumenten } \\
\text { in te zetten of door doelen aan te passen }\end{array}$ \\
\hline $\begin{array}{l}\text { Aandacht voor } \\
\text { Noordzee }\end{array}$ & Ja, maar opgenomen in landelijk beeld \\
\hline $\begin{array}{l}\text { Suggestie voor } \\
\text { extra uitwerking } \\
\text { voor Noordzee }\end{array}$ & $\begin{array}{l}\text { Kan specifiek worden uitgewerkt voor de Noordzee Natura } 2000 \text {-gebieden. Voor de } \\
\text { periode } 2013 \text { t/m } 2018 \text { is een beoordeling gemaakt voor Noordzee- } \\
\text { habitatrichtlijnsoorten. Deze is nu nog in concept en zal definitief worden gemaakt } \\
\text { in } 2019 \text { voor de indiening van de artikel } 17 \text { rapportage. WMR heeft aan deze } \\
\text { beoordeling meegewerkt voor de soorten in de mariene gebieden. De staat van } \\
\text { instandhouding van broedvogels en van de overwinterende vogelpopulaties is } \\
\text { gebaseerd op de gegevens van SOVON. De trends kunnen worden aangegeven. } \\
\text { Het aantal vogels per soort wordt gemonitord op de Noordzee vanwege de } \\
\text { monitoringeisen die voortvloeien uit de Vogelrichtlijn (art } 12 \text { rapportage en Natura } \\
\text { 2000-gebieden) en de Kaderrichtlijn Mariene Strategie (Van Roomen et al., 2013). }\end{array}$ \\
\hline
\end{tabular}

\section{Ecosysteemkwaliteit land en water}

\begin{tabular}{|c|c|}
\hline $\begin{array}{l}\text { Beleidsdoel Natuur van } \\
\text { PBL }\end{array}$ & Ecosysteemkwaliteit land en water \\
\hline Doelstelling & Verbeteren van de natuurkwaliteit \\
\hline $\begin{array}{l}\text { Resultaat Balans } \\
2018\end{array}$ & $\begin{array}{l}\text { De gemiddelde natuurkwaliteit van landnatuur is afgenomen, maar de laatste } \\
\text { jaren is de achteruitgang gestopt. De natuurkwaliteit van zoetwater verbetert } \\
\text { sinds } 1990 .\end{array}$ \\
\hline $\begin{array}{l}\text { Behalen van } \\
\text { doelstelling in balans } \\
2018\end{array}$ & $\begin{array}{l}\text { Geraamde ontwikkeling leidt waarschijnlijk niet tot het halen van het doel, met } \\
\text { intensivering van het beleid is het doel wel realiseerbaar }\end{array}$ \\
\hline $\begin{array}{l}\text { Aandacht voor } \\
\text { Noordzee }\end{array}$ & Nee, alleen voor landnatuur en zoetwaternatuur \\
\hline $\begin{array}{l}\text { Suggestie voor extra } \\
\text { uitwerking voor } \\
\text { Noordzee }\end{array}$ & $\begin{array}{l}\text { Deze kan worden uitgebreid met zeevissen en zeevogels en zeezoogdieren } \\
\text { a.d.h.v. voorkomen van een set van kenmerkende soorten van de Noordzee } \\
\text { (\%), eventueel opgesplitst per habitattype of regio. Voor de zeebodem habitats } \\
\text { is in } 2016 \text { is een benthische indicator soorten index (BISI) ontwikkeld als } \\
\text { nationale benthos indicator die specifiek is bedoeld voor evaluaties en } \\
\text { beoordelingen van de habitat-kwaliteitstoestand van de zeebodem voor o.a. de } \\
\text { Kaderrichtlijn Mariene Strategie (KRM) en de Habitatrichtlijn (Natura 2000) } \\
\text { (Wijnhoven et al., 2013; Wijnhoven \& Bos, 2017). } \\
\text { In } 2015 \text { is de Nederlandse Noordzee voor het eerst volgens het KRM-benthos } \\
\text { monitoringprogramma bemonsterd (T0-meetpunt).Wijnhoven (2018) } \\
\text { presenteerde de kwaliteitstoestand van de habitats van de zeebodem van de } \\
\text { Nederlandse Noordzee in } 2015 \text { evenals de ontwikkeling van de }\end{array}$ \\
\hline
\end{tabular}




\section{Ecologische barrières}

\begin{tabular}{|c|c|}
\hline $\begin{array}{l}\text { Beleidsdoel Natuur van } \\
\text { PBL }\end{array}$ & Ecologische barrières door aanleg nationale infrastructuur \\
\hline Doelstelling & $\begin{array}{l}\text { Verbetering van de ruimtelijke samenhang tussen natuurgebieden en daarnaast } \\
\text { het oplossen van lokale knelpunten door versnippering binnen gebieden als } \\
\text { gevolg van rijksinfrastructuur }\end{array}$ \\
\hline $\begin{array}{l}\text { Resultaat Balans } \\
2018\end{array}$ & $\begin{array}{l}\text { Eind } 2018 \text { zijn naar verwachting } 159 \text { van de } 178 \text { in het Meerjarenprogramma } \\
\text { Ontsnippering opgenomen knelpunten opgelost. De herziene doelstelling wordt } \\
\text { niet tijdig gehaald (eind } 2018 \text { ) maar beleid is ingezet om het merendeel van de } \\
\text { resterende knelpunten na } 2018 \text { op te lossen. }\end{array}$ \\
\hline $\begin{array}{l}\text { Behalen van } \\
\text { doelstelling in balans } \\
2018\end{array}$ & $\begin{array}{l}\text { Geraamde ontwikkeling ligt rond het doel, beleid zou robuust gemaakt kunnen } \\
\text { worden voor tegenvallers }\end{array}$ \\
\hline $\begin{array}{l}\text { Aandacht voor } \\
\text { Noordzee }\end{array}$ & Nee, alleen voor landnatuur en zoetwaternatuur \\
\hline $\begin{array}{l}\text { Specifiek over } \\
\text { Noordzee }\end{array}$ & $\begin{array}{l}\text { Ook op de Noordzee kan infrastructuur en andere activiteiten een barrière } \\
\text { vormen. Dit wordt o.a. veroorzaakt door windparken, kustverdediging, statische } \\
\text { visserijnetten en militaire activiteiten. Deze activiteiten en hun drukfactoren zijn } \\
\text { semi-kwantitatief beoordeeld in een risicoschatting voor Europese regionale } \\
\text { zeeën (Knights et al, 2015; Piet et., 2018). De eenheid voor dit beleidsdoel } \\
\text { ecologische barrières is anders dan bij land en zoetwater, namelijk potentiele } \\
\text { risico's voor soorten in plaats van aantal knelpunten. }\end{array}$ \\
\hline
\end{tabular}

Een zeer bruikbare bron van informatie, waarin in bovenstaande tabellen al is gerefereerd, is het resultaat van een project dat door WMR is uitgevoerd in opdracht van Ministerie van Economische Zaken (Edo Knegtering). Dit had als doel een complete lijst van soorten en hun verspreiding in Nederlandse zoute wateren, met nadruk op de Noordzee, op te stellen (gerapporteerd in Bos et al., 2016). Daarbij is tevens aandacht besteed aan de soorten die relevant zijn voor het beleid in Nederland. Dit gaat om:

- Habitatrichtlijnsoorten (Habitat Directive species) van de Nederlandse Noordzee (bijl. II, IV en V HR).

- Typische soorten van habitattypen behorend tot "kusthabitats en halofytenvegetaties" (i.e. H1110, H1140, H1170, H1310, H1320, H1330; cumulatieve tabel)

- Vogelrichtlijnsoorten (Bird Directive species) van de Nederlandse Noordzee

- Nederlandse Noordzee-soorten op de OSPAR lijst van bedreigde en/of achteruitgaande soorten en habitats bedreigde en kwetsbare soorten en habitats (2008)

- Nederlandse mariene soorten van de Rode lijst vissen (2015) en zoogdieren (2009)

- Door Nederland gemonitorde indicatorsoorten voor de EU-Kaderrichtlijn Mariene Strategie

- Soorten van beleidsplannen

De Noordzee en de andere zoutwatergebieden omvatten samen ca. $62 \%$ van het totale Nederlandse oppervlak (inclusief NCP). Het aantal mariene soorten in de Noordzee is 1284 en vormt daarmee slechts 4 tot $5 \%$ van de totale Nederlandse soortenrijkdom (Bos et al., 2016). Dit is voor een belangrijk deel in verband te brengen met de grote verscheidenheid aan habitats op land en de grotere habitatcomplexiteit. Op een hoger taxonomisch niveau is de biodiversiteit van de zee juist groter. Zo komen verschillende dierfyla uitsluitend-en-alleen in zout water voor, en niet op land.

OSPAR lijst van bedreigde en/of afnemende soorten en habitats

Van de 123 OSPAR aanbevelingen (o.a. met betrekking tot monitoring, onderzoek, de mogelijkheden tot het aanwijzen van beschermde gebieden) voor soorten en habitats die voor Nederland relevant zijn 
waren er in 201646 geïmplementeerd. Voor 19 aanbevelingen is beargumenteerd dat deze niet zijn geïmplementeerd terwijl het merendeel van de aanbevelingen nog niet specifiek zijn geadresseerd.

Tabel 411 Implementatie van aanbevelingen voor de OSPAR lijst van bedreigde en/of afnemende soorten en habitats (OSPAR, 2008) die voor Nederland relevant zijn (op basis van Bos et al., 2012) volgens de situatie in 2016

\begin{tabular}{|c|c|c|c|c|}
\hline \multirow{3}{*}{ Soorten en habitats } & \multicolumn{4}{|c|}{ Aantal aanbevelingen } \\
\hline & \multirow{2}{*}{ Total| } & \multicolumn{2}{|c|}{ Geilmplementeerd } & \multirow{2}{*}{$\begin{array}{c}\text { Nog } \\
\text { onbekend }\end{array}$} \\
\hline & & Wel & Niet & \\
\hline \multicolumn{5}{|l|}{ Vis } \\
\hline Elft & 8 & 3 & 5 & \\
\hline Kortsnuitzeepaardje & 7 & & & 7 \\
\hline Langsnuitzeepaardje & 7 & & & 7 \\
\hline Stekelrog & 8 & 7 & 1 & \\
\hline Zalm & 13 & & & 13 \\
\hline Zeeprik & 10 & 6 & 4 & \\
\hline \multicolumn{5}{|l|}{ Habitats } \\
\hline Getijdenplaten & 11 & & & 11 \\
\hline Zandkokerwormriffen & 9 & 5 & 4 & \\
\hline Zeegrasvelden & 11 & & & 11 \\
\hline $\begin{array}{l}\text { Zeeveer en gravende megafauna } \\
\text { gemeenschappen }\end{array}$ & 9 & & & 9 \\
\hline \multicolumn{5}{|l|}{ Invertebraten } \\
\hline Noordkromp & 8 & 6 & 2 & \\
\hline Platte oester & 12 & 9 & 3 & \\
\hline \multicolumn{5}{|l|}{ Zeezoogdieren } \\
\hline Bruinvis & 10 & 10 & & \\
\hline Totaal & 123 & 46 & 19 & 58 \\
\hline
\end{tabular}




\section{Discussie en aanbevelingen}

\subsection{Toestandsbeschrijving}

Als eerste aanzet tot een mogelijke Noordzee bijdrage aan de Balans van de Leefomgeving is de toestandsbeschrijving van de Noordzee in dit rapport zo opgezet dat het aansluit bij de meest relevante beleidskaders. Vanwege de gekozen focus op de KRM is het nu grotendeels gebaseerd op de geactualiseerde Mariene Strategie deel 1 (Ministerie van I\&W en LNV, 2018). Er is voor deze focus gekozen omdat:

- Het aansluit bij zowel het nationale als het Europese beleid om een goede milieutoestand (GMT) van het mariene milieu te bereiken en te behouden;

- $\quad B i j$ het actualiseren van de Mariene Strategie deel 1 rekening is gehouden met beleid, randvoorwaarden en ambities vanuit verschillende beleidsvelden die relevant zijn voor de goede milieutoestand, met name het Gemeenschappelijk Visserijbeleid (GVB), de Kaderrichtlijn Water (KRW), de Vogelrichtlijn (VR), Habitatrichtlijn (HR), en de Biodiversiteit Strategie. Hiermee wordt dus direct een breder beleidsveld meegenomen;

- $\quad$ Er afstemming is met andere Noordzeelanden wat betreft beoordeling van de toestand, het stellen van doelen en het nemen van maatregelen.

Kanttekeningen hierbij zijn:

- De beoordelingscyclus van de KRM is 6-jaarlijks, terwijl de Natuurbalans 2-jaarlijks is met een jaarlijkse tussenrapportage. Veel van de informatie in dit rapport komt uit de geactualiseerde Mariene Strategie deel 1 (Ministerie van I\&W en LNV, 2018) en er is slechts deels gebruik gemaakt van andere bronnen (OSPAR, Informatiehuis Marien, CLO). Om tot een (2-)jaarlijkse toestandsbeoordeling te komen is het nodig om een vaste toegang te hebben tot de monitoringsgegevens en deze op een gestructureerde wijze te kunnen opslaan, verwerken en beoordelen. De mogelijkheden hiertoe zijn in dit stadium niet onderzocht. Indien de rapportage NatuurBalans Noordzee gecontinueerd wordt zal dit opvolging moeten krijgen.

- Veel van de KRM-indicatoren zijn momenteel nog niet voldoende uitgewerkt. Verdere ontwikkeling verloopt vaak in internationaal (OSPAR, ICES) verband en actualisatie zal pas over 6 jaar gepubliceerd worden. Een optie is om voor de NatuurBalans Noordzee tijdelijk te kiezen voor alternatieve indicatoren en uit te breiden met indicatoren die in de aanloop naar de volgende beoordeling beschikbaar komen. In deze rapportage is daar soms al een eerste aanzet toe gegeven maar deze optie zou nader kunnen worden onderzocht.

Mogelijkheden

In hoofdstuk 5 is de milieutoestand geaggregeerd weergegeven, waarbij er voor wat betreft de KRM status maar twee mogelijkheden zijn: indien voor een criterium de GMT is gehaald is de status goed (1) terwijl de status slecht (0) is indien de GMT niet is gehaald of onbekend is. Voor een aantal criteria zal het mogelijk zijn een meer kwantitatief doelbereik op te nemen. Bijvoorbeeld voor commerciële vissoorten is de GMT ( $100 \%$ van de soorten voldoen aan een visserijsterfte F $\leq$ Fmsy en een paaibiomassa boven het voorzorgniveau MSY Btrigger) niet gehaald en krijgt dus de status slecht (0). Echter, 26\% van de soorten voldoen wel aan de criteria (zie paragraaf 4.3.2), zodat een score van 0,26 in plaats van 0 een meer realistische weergave van de status geeft. De mogelijkheid om de status zo kwantitatief mogelijk op te nemen is momenteel nog niet onderzocht maar kan, indien gewenst, wel worden uitgewerkt.

\subsection{Evaluatie beleid}

Voor de evaluatie van het beleid zijn bovenstaande opmerkingen ook van toepassing. Daarnaast is de stoplichtbenadering van het PBL voor de Noordzee uitgebouwd. Waar de beleidsevaluatie voor het land 
en zoetwater uitsluitend ingaat op de vraag of het huidig beleid voldoende is, is in dit rapport de beleidsevaluatie tweeledig toegepast:

- Is het beleidsdoel bereikt (GMT wel/niet gehaald);

- Is het huidig beleid voldoende om de GMT te behouden of in de toekomst te bereiken.

Hierbij zijn ook de kennisopgaven betrokken die voor sommige aspecten van de GMT zijn vastgesteld indien er nog onzekerheden en/of onduidelijkheden bestaan. Op termijn kan dit mogelijk ook tot een (aanvullende) beleidsopgave leiden. De kennisvragen zijn per descriptor genoemd in hoofdstuk 4 en staan ook opgesomd weergegeven in paragraaf 6.3 .

Naast de stoplichtbenadering en kennisvragen is ook een aanzet gegeven dit samen te vatten tot iets wat relevant is voor beleid wat vervolgens de basis kan zijn van een mogelijke een prioritering van beheer(maatregelen) (zie paragraaf 5.3). Hiervoor zijn de resultaten uit de CEA gecombineerd met de resultaten uit de geactualiseerde Mariene Strategie deel 1 (Ministerie van I\&W en LNV, 2018). Dit zou mogelijk uitgebreid en/of aangepast kunnen worden met bijvoorbeeld inzichten per criterium/indicator in plaats van op descriptor niveau of risico per activiteit, drukfactor en/of ecosysteem component.

\subsection{Evaluatie van maatregelen}

Door Piet et al. (2014) is enkele jaren geleden voor het Nederlandse KRM Programma van Maatregelen de CEA methodiek toegepast. Hierbij is per maatregel inzichtelijk gemaakt via hoeveel effectketens deze ingrijpt op het ecosysteem, en daarnaast is de potentiele risico reductie weergegeven. De gebruikte CEA methodiek is inmiddels verbeterd en geactualiseerd waardoor de analyse van het programma van maatregelen (Piet et al., 2014), opnieuw zou kunnen worden uitgevoerd, met daarbij een geactualiseerde set van maatregelen. Dit zou het huidige programma van maatregelen kunnen zijn (Ministerie van IenM \& EZ, 2015) of een herziene versie welke wordt verwacht in 2021.

De Bow-tie methodiek sluit goed aan bij de huidige CEA methodiek en komt voort uit het ISO 31000 risicomanagement en wordt o.a. binnen OSPAR gepropageerd omdat het bruikbaar is voor sturing van integraal beheer. Er is voorlopig gekozen het niet uitgebreid te behandelen in dit rapport. Een voorbeeld van een Bow-tie analyse is ter illustratie opgenomen in Bijlage 8. De Bow-tie analyse inclusief de mogelijkheden daarvan voor de NatuurBalans Noordzee, kan in een eventueel vervolg onderzoek worden uitgewerkt. 


\section{Kwaliteitsborging}

Wageningen Marine Research beschikt over een ISO 9001:2015 gecertificeerd kwaliteitsmanagementsysteem. Dit certificaat is geldig tot 15 december 2021. De organisatie is gecertificeerd sinds 27 februari 2001. De certificering is uitgevoerd door DNV GL. 


\section{Literatuur}

Batsleer, J., Rijnsdorp, A. D., Hamon, K. G., van Overzee, H. M. J., \& Poos, J. J. (2016). Mixed fisheries management: Is the ban on discarding likely to promote more selective and fuel efficient fishing in the Dutch flatfish fishery? Fisheries Research, 174, 118-128. https://doi.org/10.1016/j.fishres.2015.09.006

Besseling E. (2018). Micro- and nanoplastic in the aquatic environment - From rivers to whales. PhD thesis, Wageningen University, Wageningen. DOI: https://doi.org/10.18174/441167

Borgwardt F., L. Robinson, D. Trauner, H. Teixeira, A.J.A. Nogueira, A.I. Lillebø, G. Piet, M. Kuemmerlen, T. O'Higgins, H. McDonald, J. Arevalo-Torres, A. Luisa Barbosa, A. Iglesias-Campos, T. Hein, F. Culhane (2019). Exploring variability in environmental impact risk from human activities across aquatic ecosystems. Science of The Total Environment Volume 652, Pages 13961408, https://doi.org/10.1016/j.scitotenv.2018.10.339.

Bos, O.G., A. Gittenberger, I. de Boois, M. van Asch, J.T van der Wal, J. Cremer, B. van der Hoorn, S. Pieterse, P.A.J. Bakker (2016). Soortenlijst Nederlandse Noordzee. Wageningen Marine Research rapport C125/16. DOI: https://doi.org/10.18174/401117

Bos, O.G., R. van Hal, R. van Bemmelen, A.J. Paijmans, M.T. van der Sluis (2012): OSPAR threatened and/or declining species and habitats in the Netherlands. WMR Report number C134/12. http://edepot.wur.nl/248714

Camphuijsen, C.J. (2013). A historical ecology of two closely related gull species (Laridae): Multiple adaptations to a man-made environment. Rijksuniversiteit Groningen.

Camphuysen CJ (1995). Herring gull Larus argentatus and Lesser Black-backed Gull L. fuscus feeding at fishing vessels in the breeding season: competitive scavenging versus efficient flying. Ardea 83(2): 365-380.

Catchpole, T. L., Ribeiro-Santos, A., Mangi, S. C., Hedley, C., \& Gray, T. S. (2017). The challenges of the landing obligation in EU fisheries. Marine Policy, 82, 76-86. https://doi.org/10.1016/j.marpol.2017.05.001

CBS, PBL, RIVM, WUR (2017a). Fauna in de kustzone, 1990-2015 (indicator 1596, versie 01,27 oktober 2017 ). www.clo.nl. Centraal Bureau voor de Statistiek (CBS), Den Haag; PBL Planbureau voor de Leefomgeving, Den Haag; RIVM Rijksinstituut voor Volksgezondheid en Milieu, Bilthoven; en Wageningen University and Research, Wageningen.

CBS, PBL, RIVM, WUR (2017b). Zeevogels in de Noordzee buiten de kustzone, 1991-2013 (indicator 1576, versie 01 , 30 oktober 2017 ). www.clo.nl. Centraal Bureau voor de Statistiek (CBS), Den Haag; PBL Planbureau voor de Leefomgeving, Den Haag; RIVM Rijksinstituut voor Volksgezondheid en Milieu, Bilthoven; en Wageningen University and Research, Wageningen.

CBS, PBL, RIVM, WUR (2017c). Roggen en haaien, 1945-2016 (indicator 1249, versie 10 , 30 oktober 2017 ). www.clo.nl. Centraal Bureau voor de Statistiek (CBS), Den Haag; PBL Planbureau voor de Leefomgeving, Den Haag; RIVM Rijksinstituut voor Volksgezondheid en Milieu, Bilthoven; en Wageningen University and Research, Wageningen.

CBS, PBL, RIVM, WUR (2017d). Bodemfauna Noordzee en bodemvisserij (indicator 1251, versie 05 , 26 januari 2017 ). www.clo.nl. Centraal Bureau voor de Statistiek (CBS), Den Haag; PBL Planbureau voor de Leefomgeving, Den Haag; RIVM Rijksinstituut voor Volksgezondheid en Milieu, Bilthoven; en Wageningen University and Research, Wageningen.

CBS, PBL, RIVM, WUR (2018). Migratiemogelijkheden voor trekvissen, 2018 (indicator 1350, version 09 , 19 april 2018 ). www.environmentaldata.nl. Statistics Netherlands (CBS), The Hague; PBL Netherlands Environmental Assessment Agency, The Hague; RIVM National Institute for Public Health and the Environment, Bilthoven; and Wageningen University and Research, Wageningen.

Cormier, R., Elliott, M., and Kannen, A. (2018). IEC/ISO Bow-tie analysis of marine legislation: A case study of the Marine Strategy Framework Directive. ICES Cooperative Research Report No. 342. 56 pp. https://doi.org/10.17895/ices.pub.4504 
Cremer, J.S.M., S.M.J.M. Brasseur., A. Meijboom, J. Schop \& J.P. Verdaat (2017). Monitoring van gewone en grijze zeehonden in de Nederlandse Waddenzee, 2002-2017. Wageningen, Wettelijke Onderzoekstaken Natuur \& Milieu, WUR. WOt-technical report 104 (WMR-rapport: C095/17).

Deltares (2013). Summary report Plastic litter in Rhine, Meuse and Scheldt, contribution to plastic litter in the North Sea. http://www.kenniswijzerzwerfafval.nl/download_document/570

Ecoauthor (2018), T0 beoordeling kwaliteitstoestand NCP op basis van de Benthische Indicator Soorten Index (BISI). Te downloaden via: http://ecoauthor.net/wpcontent/uploads/2018/09/Eindrapport-T0-kwaliteit-benthische-habitats-KRM-Noordzee.pdf

European Commission (2011). Commission staff working paper. Relationship between the initial assessment of marine waters and the criteria for good environmental status. SEC(2011) 1255 final. Beschikbaar via: http://ec.europa.eu/environment/marine/pdf/SEC_2011_1255_F_DTS.pdf

Europese Commissie (2014). Het gemeenschappelijk visserijbeleid (GVB). Brussel, Commissie van de Europese Gemeenschappen.

Europese Commissie (2017). Besluit (EU) 2017/848 van de Commissie van 17 mei 2017 tot vaststelling van criteria en methodologische standaarden inzake de goede milieutoestand van mariene wateren en specificaties en gestandaardiseerde methoden voor monitoring en beoordeling, en tot intrekking van Besluit 2010/477/EU. Te downloaden via: https://publications.europa.eu/en/publication-detail/-/publication/a7523a58-3b91-11e7-a08e01aa75ed71a1/language-nl

Europese Unie (2011): De biodiversiteitsstrategie van de EU voor de periode tot 2020. Beschikbaar via:

http://ec.europa.eu/environment/pubs/pdf/factsheets/biodiversity_2020/2020\%20Biodiversity\%2 OFactsheet_NL.pdf

Europese Unie (2016): Feiten en cijfers over het gemeenschappelijk visserijbeleid. Statistische basisgegevens. Gedownload op 8 januari 2019 via: https://ec.europa.eu/fisheries/sites/fisheries/files/docs/body/pcp_nl.pdf

GESAMP (2015). Sources, occurrence and effects in marine environment; a global assessment. http://ec.europa.eu/environment/marine/good-environmental-status/descriptor10/pdf/GESAMP_microplastics\%20full\%20study.pdf

Gittenberger, A., Rensing, M. \& Wesdorp, K.H. (2017a). Uitheemse mariene soorten in Nederland. GiMaRIS-rapport 2017_19. Leiden: GiMaRIS. (Nederlandstalige versie.) https://www.noordzeeloket.nl/publish/pages/138275/uitheemse_mariene_soorten_in_nederland.p df

Gittenberger, A., Rensing, M. \& Wesdorp, K.H. (2017b). Nonindigenous marine species in the Netherlands. GiMaRIS report 2017_13. Leiden, the Netherlands: GiMaRIS. (Engelstalige versie.) https://www.noordzeeloket.nl/publish/pages/138273/nonindigenous_marine_species_in_the_netherlands.pdf

Haraldsson M., N.L. Arroyo, E. Capuzzo, P. Claquin, J. Kromkamp, N. Niquil, C. Ostle, I. Preciado, G. Safi (2017). Report on the integration of OSPAR Food Webs Indicators into the NEAT tool EcApRHA Deliverable WP 3.5. EcApRHA 3.5/2017

Haraldsson M., N.L. Arroyo, E. Capuzzo, P. Claquin, J. Kromkamp, N. Niquil, C. Ostle, I. Preciado, G. Safi (2017). Report on the integration of OSPAR Food Webs Indicators into the NEAT tool EcApRHA Deliverable WP 3.5

ICES (2017). ICES Special Request Advice sr.2017.13. EU request on indicators of the pressure and impact of bottom-contacting fishing gear on the seabed, and of trade-offs in the catch and the value of landings. Published 6 July 2017. Available at: http://www.ices.dk/sites/pub/Publication\%20Reports/Advice/2017/Special_requests/eu.2017.13.p df

ICES (2018). ICES Fisheries Overviews. Greater North Sea Ecoregion. Published 30 November 2018. https://doi.org/10.17895/ices.pub.4647

Jongbloed R.H., P. de Vries, J.E. Tamis, G. Piet (in prep.). Natuurverkenning van de Noordzee. Mogelijkheden en voorbeelden. Concept versie. Wageningen Marine Research, Den Helder

Knights, A.M., Piet, G.J., Jongbloed, R., Tamis, J.E., Robinson, L.A., et al., 2015. An exposure-effect approach for evaluating ecosystem-wide risks from human activities. ICES J. Mar. Sci. 72, 11051115. https://doi.org/10.1093/icesjms/fsu245.

Leslie, H.A., et al. (2017). Microplastics en route: Field measurements in the Dutch river delta and Amsterdam canals, wastewater treatment plants, North Sea sediments and biota. https://ac.els- 
cdn.com/S0160412017301654/1-s2.0-S0160412017301654-main.pdf?_tid=77d88556-e0c3-

11e7-a518-00000aacb361\&acdnat=1513251759_29b94a2d2d977c40171ab7bf1b790c7d

Matthijsen J., E. Dammers \& H. Elzenga (2018). De toekomst van de Noordzee. De Noordzee in 2030 en 2050: een scenariostudie, Den Haag: PBL.

Ministerie van Infrastructuur en Milieu \& Ministerie van Economische Zaken, Landbouw en Innovatie (2012). Mariene Strategie voor het Nederlandse deel van de Noordzee 2012-2020, Deel 1.

Ministerie van Infrastructuur en Milieu \& Ministerie van Economische Zaken (2014). Mariene Strategie voor het Nederlandse deel van de Noordzee 2012-2020, Deel 2 KRM-monitoringprogramma. Den Haag. Te downloaden via:

https://www.noordzeeloket.nl/beleid/europese/achtergrond/documenten-mariene/

Ministerie van Infrastructuur en Milieu \& Ministerie van Economische Zaken (2015). Mariene Strategie voor het Nederlandse deel van de Noordzee 2012-2020 (deel 3). KRM-programma van maatregelen. Bijlage 5 bij het Nationaal Waterplan 2016-2021. Te downloaden via: https://www.noordzeeloket.nl/beleid/europese/achtergrond/documenten-mariene/

Ministerie van Infrastructuur en Milieu (2015a). Beleidsnota Noordzee 2016-2021 https://www.rijksoverheid.nl/binaries/rijksoverheid/documenten/beleidsnota-s/2015/12/14/ beleidsnota-noordzee-2016-2021/nz-nl-beeldscherm.pdf

Ministerie van Infrastructuur en Milieu (2015b). Nationaal Waterplan 2016-2021 https://www.rijksoverheid.nl/binaries/rijksoverheid/documenten/beleidsnotas/2015/12/14/nationaal- waterplan-2016-2021/nwp-2016-2021.pdf

Ministerie van Infrastructuur en Milieu en Ministerie van Economische Zaken (2014): Ontwerp Beleidsnota Noordzee 2016-2021, Bijlage 2 bij het Nationaal Waterplan 2016-2021

Ministerie van Infrastructuur en Waterstaat \& Ministerie van Landbouw, Natuur en Voedselkwaliteit (2018): Mariene Strategie (deel 1). Actualisatie van huidige milieutoestand, goede milieutoestand, milieudoelen en indicatoren. 2018-2024. Juni 2018. Te downloaden via: https://www.rijksoverheid.nl/regering/bewindspersonen/cora-vannieuwenhuizen/documenten/rapporten/2018/06/21/bijlage-5-mariene-strategie

Ministerie van Infrastructuur en Waterstaat \& Ministerie van Landbouw, Natuur en Voedselkwaliteit (2018): Mariene Strategie (deel 1). Actualisatie van huidige milieutoestand, goede milieutoestand, milieudoelen en indicatoren. 2018-2024. Juni 2018. Te downloaden via:

https://www.rijksoverheid.nl/regering/bewindspersonen/cora-van-

nieuwenhuizen/documenten/rapporten/2018/06/21/bijlage-5-mariene-strategie

OSPAR (2008): OSPAR List of Threatened and/or Declining Species and Habitats (Reference Number: 2008-6). Available at: https://www.ospar.org/work-areas/bdc/species-habitats/list-of-threateneddeclining-species-habitats

OSPAR Commission 2000. Quality Status Report 2000. OSPAR Commission, London. Available at: https://qsr2010.ospar.org/media/assessments/QSR_2000.pdf

OSPAR Commission 2010. Quality Status Report 2010. OSPAR Commission, London. Available at: https://qsr2010.ospar.org/en/media/chapter_pdf/QSR_complete_EN.pdf

OSPAR (2017). Intermediate Assessment 2017. Available at: https://oap.ospar.org/en/osparassessments/intermediate-assessment-2017

PBL (2018). Balans voor de Leefomgeving 2018. Digitale Balans: http://themasites.pbl.nl/balansvandeleefomgeving/jaargang-2018/themas/natuur

Piet, G., F. Culhane, R. Jongbloed, L. Robinson, B. Rumes, J. Tamis (2018): An integrated risk-based assessment of the North Sea to guide ecosystem-based management. Science of the Total Environment 654 (2019) 694-704. https://doi.org/10.1016/j.scitotenv.2018.11.001

Piet, G. K. Wolfshaar, P. de Vries, A. Asjes, R.H. Jongbloed, J.E. Tamis (in prep.) Modellenvisie Wageningen Marine Research. Relevante modellen voor toestand beoordeling en beleidsadvies Noordzee. Draft versie. Wageningen Marine Research, IJmuiden

Polet, H., \& Depestele, J. (2010). Impact assessment of the effects of a selected range of fishing gears in the north sea. ILVO Technisch Visserijonderzoek, 110.

Polet, H., Depestele, J., Craeynest, K. Van, Andersen, B. S., Madsen, N., Marlen, B. van, et al. (2010). Draft Final Report. Scientific advice concerning the impact of the gears used to catch plaice and sole.

Rijkswaterstaat (2016). Factsheets ten behoeve van het opstellen van het Stroomgebiedbeheerplan 2021 en de daaraan gerelateerde waterplannen. Beschikbaar via: 
https://www.waterkwaliteitsportaal.nl/Beheer/Data/Publiek?viewName=Factsheets\&year=2016\&m onth $=$ December

Röckmann, C., Quirijns, F., \& Van Overzee, H. (2011). Discards in fisheries - a summary of three decades of research at IMARES and LEI.

Scheidat M., B. Couperus, M. Siemensma (2018). Electronic monitoring of incidental bycatch of harbour porpoise (Phocoena phocoena) in the Dutch bottom set gillnet fishery (September 2013 to March 2017). Wageningen Marine Research report C102/18. IJmuiden. https://doi.org/10.18174/466450

Schultz van Haegen-Maas Geesteranus, M. H. (2016). Mariene Strategie voor het Nederlandse deel van de Noordzee; Brief regering; Bodembescherming Friese Front en Centrale Oestergronden. Parlementaire monitor: Parlementaire monitor. Retrieved from https://www.parlementairemonitor.nl/9353000/1/j9vvij5epmj1ey0/vk4xg9dbeuy5

Steins N., M. Kraan, R. Verkempynck, P. Molenaar en A. Rijnsdorp (2018). Q\&A Europese aanlandplicht visserij, Wageningen Marine Research, februari 2018. Available at: https://www.wur.nl/nl/Dossiers/dossier/Discards-Ongewenste-bijvangst.htm

Steins, N., Kraan, M., \& Verkempynck, R. (2018). Q \& A Europese aanlandplicht visserij.

Teixeira H., A.I. Lillebø, F. Culhane, L. Robinson, D. Trauner, F. Borgwardt, M. Kuemmerlen, A. Barbosa, H. McDonald, A. Funk, T. O'Higgins, J.T. Van der Wal, G. Piet, T. Hein, J. Arévalo-Torres, A. Iglesias-Campos, J. Barbière, A.J.A. Nogueira (2019). Linking biodiversity to ecosystem services supply: Patterns across aquatic ecosystems, Science of The Total Environment, Volume 657, Pages 517-534, https://doi.org/10.1016/j.scitotenv.2018.11.440

Tien, N.S.H., Heessen, H., Kranenbarg, J. \& Trapman, B. (2016) Achtergronddocument Rode lijst vissen 2011: zoutwatervissen. IJmuiden: IMARES Wageningen UR. IMARES-rapport C021/16. (http://library.wur.nl/WebQuery/wurpubs/fulltext/378196).

TNO (2015). Cumulatieve effecten van impulsief onderwatergeluid op zeezoogdieren.

Van Duren, L.A., Gittenberger A., Smaal A.C., Koningsveld M. van, Osinga R., Cado van der Lelij J.A., Vries M.B. de (2016) Rijke riffen in de Noordzee: verkenning naar het stimuleren van natuurlijke riffen en gebruik van kunstmatig hard substraat. Deltares Report: 1221293-000-ZKS-0009. Deltares, Delft. http://publications.deltares.nl/1221293_000.pdf

Van Helmond, A. T. M., \& Steins, N. A. (2016). Vangstsamenstelling per tuigcategorie Herziening contingentenstelsel visserij in Nederland in het kader van de aanlandplicht.

Van Kleunen A., van Winden E., Dreef C., Foppen R. \& van Roomen M. 2016. Rode, Oranje en Blauwe Lijst van doortrekkende en overwinterende vogelpopulaties in Nederland - technische rapportage. Sovon-rapport 2016/01, Sovon Vogelonderzoek Nederland, Nijmegen.

Van Kooten T. (2017) The Wozep Monitoring and Research Programme; An evaluation in light of research results and policy developments. IJmuiden, Wageningen Marine Research, Wageningen Marine Research report C084/17.

Van Roomen, M., Stahl, J, Schekkerman, H, Van Turnhout, C \& Vogel, R. (2013) Advies ten behoeve van het opstellen van een monitoringsplan voor vogels van het Nederlandse Noordzeegebied. Nijmegen: Sovon Vogelonderzoek Nederland. Sovon-rapport 2013/22. (https://www.sovon.nl/sites/default/files/doc/Rap_2013-22_monitoringplan_noordzee.pdf).

Vrooman, J., van Sluis, C., van Hest, F. (2018.) Gebiedsbescherming op de Nederlandse Noordzee. De stand van zaken in relatie tot visserij. Stichting De Noordzee, Utrecht

Wijnhoven, S. (2018). T0 beoordeling kwaliteitstoestand NCP op basis van de Benthische Indicator Soorten Index (BISI) Toestand en ontwikkelingen van benthische habitats en KRM-gebieden op de Noordzee in en voorafgaand aan 2015. Ecoauthor Report Series 2018 - 01.

Wijnhoven, S., Bos, O. (2017). Benthische Indicator Soorten Index (BISI). Ontwikkelingsproces en beschrijving van de Nationale Benthos Indicator Noordzee inclusief protocol voor toepassing. Rapport Ecoauthor \& Wageningen Marine Research. Ecoauthor Report Series 2017 - 02, Heinkenszand, the Netherlands.

Wijnhoven, S., Duineveld, G., Lavaleye, M., Craeymeersch, J., Troost, K., van Asch, M. (2013). Kaderrichtlijn Marien indicatoren Noordzee. Naar een uitgebalanceerde selectie van indicatorsoorten ter evaluatie van habitats en gebieden en scenario's hoe die te monitoren. Monitor Taskforce Publication Series 2013-02. NIOZ, Den Hoorn \& Yerseke, 105 pp.

Zoogdiervereniging VZZ, 2007. Basisrapport voor de Rode Lijst Zoogdieren volgens Nederlandse en IUCN-criteria. VZZ rapport 2006.027. Tweede, herziene druk. Zoogdiervereniging VZZ, Arnhem. 


\section{Verantwoording}

Rapport C034/19

Projectnummer: 4318300085 en 4318200052

Dit rapport is met grote zorgvuldigheid tot stand gekomen. De wetenschappelijke kwaliteit is intern getoetst door een collega-onderzoeker en het verantwoordelijk lid van het managementteam van Wageningen Marine Research

Akkoord:

Dr. Diana Slijkerman

Onderzoekster

Handtekening:

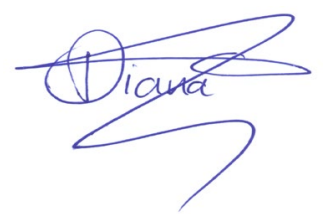

Datum:

4 april 2019

Akkoord:

Drs. Jakob Asjes

MT lid

Handtekening

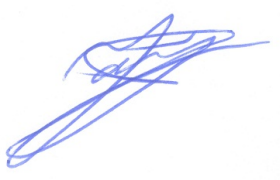

Datum:

4 april 2019 


\section{Bijlage 1 Relatie CLO indicatoren en KRM}

In onderstaande tabel staat aangegeven in hoeverre de Noordzee indicatoren van het CLO informatie kunnen geven over de milieutoestand in het kader van de KRM. Per Noordzee indicator staat aangegeven of er een relatie is tot een KRM criteria en/of indicator.

\section{Relatie CLO indicatoren met criteria en indicatoren van de KRM}

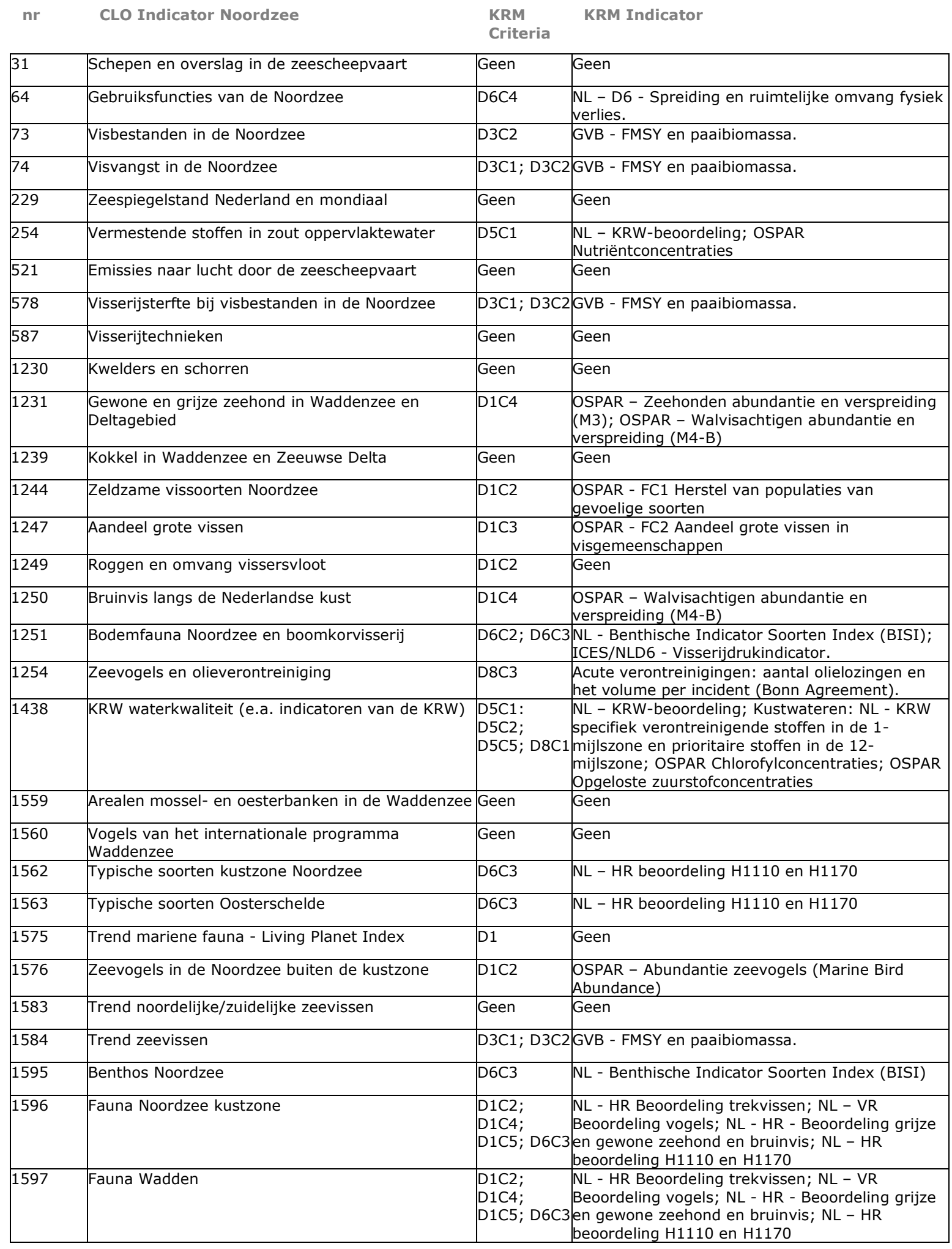




\begin{tabular}{|c|c|c|c|}
\hline 1598 & Fauna Oosterschelde & \begin{tabular}{l|} 
D1C2; \\
D1C4; \\
D1C5; D6C3
\end{tabular} & $\begin{array}{l}\mathrm{NL} \text { - HR Beoordeling trekvissen; NL - VR } \\
\text { Beoordeling vogels; NL - HR - Beoordeling grijze } \\
\text { en gewone zeehond en bruinvis; NL - HR } \\
\text { beoordeling } \mathrm{H} 1110 \text { en } \mathrm{H} 1170\end{array}$ \\
\hline 1602 & Zoutwatervissen - kinderkamersoorten & Geen & Geen \\
\hline 2153 & $\begin{array}{l}\text { Toegevoegde waarde zeehavengerelateerde } \\
\text { activiteiten }\end{array}$ & Geen & Geen \\
\hline 2159 & Biodiversiteit Noordzee & D6C3; D6C5 & $\begin{array}{l}\text { NL - Benthische Indicator Soorten Index (BISI); } \\
\text { OSPAR - Conditie van benthische } \\
\text { gemeenschappen (MMI) }\end{array}$ \\
\hline
\end{tabular}

Van de CLO indicatoren waarbij een relatie tot de KRM bestaat, is vervolgens gekeken over welke descriptor de indicator informatie geeft (zie tabel hieronder).

Vooral de descriptoren D1 (biodiversiteit) en D6 (zeebodemintegriteit) worden goed vertegenwoordigd door de CLO indicatoren. Voor de descriptoren D2 (niet-inheemse soorten). D4 (voedselweb), D9 (vervuilende stoffen in vis), D10 (zwerfvuil) en D11 (energietoevoer, o.m. onderwatergeluid) zijn er geen CLO indicatoren beschikbaar.

Relatie tussen CLO indicatoren die relevant zijn voor de KRM met descriptoren van de KRM: D1 Biodiversiteit; D2 Niet-inheemse soorten; D3 Commerciële visbestanden; D4 Voedselweb; D5 Eutrofiering; D6 Bodemintegriteit; D7 Hydrografische eigenschappen; D8 Vervuilende stoffen; D9 Vervuilende stoffen in vis; D10 Zwerfvuil; D11 Energietoevoer, o.m. onderwatergeluid.

\begin{tabular}{|c|c|c|c|c|c|c|c|c|c|c|c|}
\hline Indicator Noordzee & D1 & D2 & D3 & D4 & D5 & D6 & D7 & D8 & D9 & D10 & D11 \\
\hline Aandeel grote vissen & $\mathrm{X}$ & & & & & & & & & & \\
\hline Benthos Noordzee & & & & & & $\mathrm{X}$ & & & & & \\
\hline Biodiversiteit Noordzee & & & & & & $\mathrm{X}$ & & & & & \\
\hline Bodemfauna Noordzee en boomkorvisserij & & & & & & $\mathrm{X}$ & & & & & \\
\hline Bruinvis langs de Nederlandse kust & $\mathrm{X}$ & & & & & & & & & & \\
\hline Fauna Noordzee kustzone & $\mathrm{X}$ & & & & & $\mathrm{X}$ & & & & & \\
\hline Fauna Oosterschelde & $\mathrm{X}$ & & & & & $\mathrm{X}$ & & & & & \\
\hline Fauna Wadden & $\mathrm{X}$ & & & & & $\mathrm{X}$ & & & & & \\
\hline Fauna Westerschelde & $\mathrm{X}$ & & & & & $\mathrm{X}$ & & & & & \\
\hline Gebruiksfuncties van de Noordzee & & & & & & $\mathrm{X}$ & & & & & \\
\hline $\begin{array}{l}\text { Gewone en grijze zeehond in Waddenzee en } \\
\text { Deltagebied }\end{array}$ & $\mathrm{x}$ & & & & & & & & & & \\
\hline KRW waterkwaliteit (e.a. indicatoren van de KRW) & & & & & $\mathrm{X}$ & & $\mathrm{X}$ & $\mathrm{X}$ & & & \\
\hline Roggen en omvang vissersvloot & $\mathrm{X}$ & & & & & & & & & & \\
\hline Trend zeevissen & & & $\mathrm{X}$ & & & & & & & & \\
\hline Typische soorten kustzone Noordzee & & & & & & $\mathrm{X}$ & & & & & \\
\hline Typische soorten Oosterschelde & & & & & & $\mathrm{x}$ & & & & & \\
\hline Vermestende stoffen in zout oppervlaktewater & & & & & $\mathrm{X}$ & & & & & & \\
\hline Visbestanden in de Noordzee & & & $\mathrm{X}$ & & & & & & & & \\
\hline Visserijsterfte bij visbestanden in de Noordzee & & & $\mathrm{X}$ & & & & & & & & \\
\hline Visvangst in de Noordzee & & & $\mathrm{X}$ & & & & & & & & \\
\hline Vogels Grevelingen & $\mathrm{X}$ & & & & & & & & & & \\
\hline Zeevogels en olieverontreiniging & & & & & & & & $\mathrm{X}$ & & & \\
\hline Zeevogels in de Noordzee buiten de kustzone & $\mathrm{X}$ & & & & & & & & & & \\
\hline Zeldzame vissoorten Noordzee & $\mathrm{X}$ & & & & & & & & & & \\
\hline
\end{tabular}




\section{Bijlage 2 Relevantie AQUACROSS voor Nederlandse Noordzee}

In dit rapport is gebruik gemaakt van resultaten uit het Europese AQUACROSS project (Piet et al., 2018; Culhane et al., 2018; Borgwardt et al., 2019). Binnen het AQUACROSS project is voor de internationale Noordzee van elke impact keten het risico geschat aan de hand van criteria voor overlap (extent), verspreiding (dispersal), persistentie (persistence), frequentie (frequency) en type effect (severity). De impactketens zijn geïdentificeerd op zowel een gedetailleerd niveau als op een geaggregeerd niveau van activiteiten (specifieke activiteiten versus geaggregeerde activiteiten) en ecosysteem componenten (EUNIS niveau 3 versus EUNIS niveau 2). De uiteindelijke risico score is geschat op het geaggregeerde niveau voor activiteiten en EUNIS-2. De ecosysteem componenten zijn binnen AQUACROSS onderverdeeld per realm (Birds, Coastal, CoastalTerr, Fish \& Cephalopods, Inlets Transitional, Mammals, Oceanic, Reptiles, Shelf), zie tabel 2A. Eenzelfde EUNIS klasse kan dus meerdere keren voorkomen.

Tabel 2A. Voorkomen (aangegeven met een ' $X$ ') van de ecosysteem componenten (EUNIS-2, in kolommen) in de verschillende biogeografische eenheden (realms, in regels). Een vetgedrukte $X$ geeft aan dat deze voorkomt in de Nederlandse Noordzee en is geselecteerd voor dit rapport

\begin{tabular}{|c|c|c|c|c|c|c|c|c|c|c|c|}
\hline Realm & 蒡 & 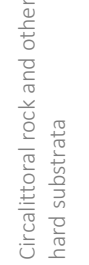 & 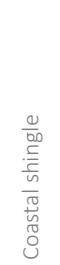 & 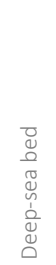 & 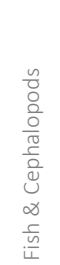 & 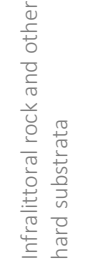 & 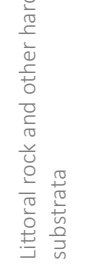 & 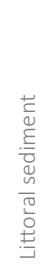 & 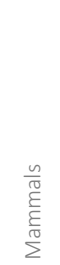 & 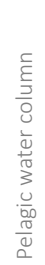 & $\begin{array}{l}\frac{\tilde{u}}{\overline{\underline{z}}} \\
\widetilde{\alpha}\end{array}$ \\
\hline Birds & $\mathbf{x}$ & & & & & & & & & & \\
\hline Coastal & & $\mathbf{x}$ & & $x$ & & $\mathrm{x}$ & $\mathrm{x}$ & $\mathbf{x}$ & & $\mathbf{x}$ & \\
\hline CoastalTerr & & & $\mathrm{x}$ & & & & & & & & \\
\hline Fish \& Cephalopods & & & & & $\mathbf{x}$ & & & & & & \\
\hline Inlets Transitional & & $x$ & & $x$ & & $x$ & $x$ & $x$ & & $x$ & \\
\hline Mammals & & & & & & & & & $\mathbf{x}$ & & \\
\hline Oceanic & & & & $\mathrm{x}$ & & & & & & $\mathbf{x}$ & \\
\hline Reptiles & & & & & & & & & & & $\mathrm{x}$ \\
\hline Shelf & & $\mathbf{x}$ & & & & & & & & $\mathbf{x}$ & \\
\hline
\end{tabular}

Niet alle EUNIS habitat typen die voor de Noordzee zijn meegenomen komen voor op het Nederlands deel (Tabel 2B2B). Daarom is voor dit rapport een selectie gemaakt, welke vetgedrukt staan weergegeven in de tabel hierboven. 
Tabel 2B Habitattypen van het Nederlands deel van de Noordzee (Ministerie van I\&W en LNV, 2018)

\begin{tabular}{|c|c|c|c|c|c|c|}
\hline EUNIS code & MB5 & $\mathrm{MC} 1,2$ & MC3 & MC5 & MD5 & MD6 \\
\hline $\begin{array}{l}\text { Breed } \\
\text { habitattype } \\
\text { KRM }\end{array}$ & $\begin{array}{l}\text { infralitoraal } \\
\text { zand }\end{array}$ & $\begin{array}{l}\text { circalitoraal } \\
\text { gesteente en } \\
\text { biogene riffen }\end{array}$ & $\begin{array}{l}\text { circalitoraal grof } \\
\text { sediment }\end{array}$ & circalitoraal zand & $\begin{array}{l}\text { circalitoraal zand } \\
\text { in zee }\end{array}$ & $\begin{array}{l}\text { circalitorale } \\
\text { modder in zee }\end{array}$ \\
\hline Diepte & ca. $0-20 \mathrm{~m}$ & ca. $20-40 \mathrm{~m}$ & ca. $20-40 \mathrm{~m}$ & ca. $20-40 \mathrm{~m}$ & ca. $40-70 \mathrm{~m}$ & ca. $40-70 \mathrm{~m}$ \\
\hline Korrelgrootte & $\begin{array}{l}\text { zand }<1 \mathrm{~mm} \text {, } \\
<30 \% \text { klei en silt } \\
(<63 \mu \mathrm{m})\end{array}$ & $\begin{array}{l}\text { niet mobiele } \\
\text { stenen }\end{array}$ & $\begin{array}{l}\text { zand > } 1 \mathrm{~mm} \text {, } \\
>5 \% \text { grind, } \\
\text { schelpen }\end{array}$ & $\begin{array}{l}\text { zand< } 1 \mathrm{~mm} \text {, } \\
<30 \% \text { klei en silt } \\
(<63 \mu \mathrm{m})\end{array}$ & $\begin{array}{l}\text { zand }<1 \mathrm{~mm} \text {, } \\
<30 \% \text { klei en silt } \\
(<63 \mu \mathrm{m})\end{array}$ & $\begin{array}{l}>30 \% \text { klei en silt } \\
(<63 \mu \mathrm{m})\end{array}$ \\
\hline Getijstroom & sterk & zwak & zwak & zwak tot sterk & zwak & zwak \\
\hline $\begin{array}{l}\text { Belangrijkste } \\
\text { voorkomen }\end{array}$ & kustzone & Klaverbank & $\begin{array}{l}\text { Doggersbank } \\
\text { Klaverbank }\end{array}$ & $\begin{array}{l}\text { Zuidelijke bocht } \\
\text { buiten de kust } \\
\text { Doggersbank }\end{array}$ & $\begin{array}{l}\text { Oestergronden } \\
\text { Klaverbank }\end{array}$ & Oestergronden \\
\hline
\end{tabular}

* deze indeling is gebaseerd op tabel 2 van het KRM Commissiebesluit en wijkt af van de indeling volgens de Habitatrichtlijn

Hieronder is een overzicht gegeven van de drukfactoren die zijn genoemd in de Nederlandse KRM beoordeling (Ministerie van I\&W en LNV, 2018) met daarnaast gerelateerde drukfactoren zoals opgenomen in de AQUACROSS analyse (Borgwardt et al., 2019).

Drukfactoren NL Noordzee (Ministerie van I\&W en LNV, 2018)

Fysieke vernietiging

Fysieke verstoring van de zeebodem

Introductie of verspreiding van niet-inheemse soorten

Onttrekking van of sterfte/letsel van in het wild levende soorten Onttrekking van of sterfte/letsel van in het wild levende soorten (directe sterfte)

Onttrekking van voedselweb)

Temperatuurstijging door klimaatverandering

Toevoer van andere stoffen (incl. olie, acute incidenten en radioactieve stoffen)

Toevoer van andere stoffen (olie: operationele lozingen en incidenten)

Toevoer van antropogeen geluid (achtergrondgeluid)

Toevoer van antropogeen geluid (luid impulsief geluid en

achtergrondgeluid)

Toevoer van antropogeen geluid (luid impulsief geluid)

Toevoer van nutriënten en organisch materiaal

Toevoer van zwerfvuil

Verstoring van soorten door menselijke aanwezigheid

Wijzigingen van hydrologische omstandigheden

Wijzigingen van hydrologische omstandigheden (doorzicht)

Wijzigingen van hydrologische omstandigheden (migratiebarrières zoet-zout)

Wijzigingen van hydrologische omstandigheden (verandering van slibgehalte)

\section{Drukfactor AQUACROSS (Borgwardt et al., 2019)}

Total Habitat Loss

Abrasion/Damage

Selective extraction of non-living resources: substrate e.g. gravel

Smothering

Artificialisation of habitat

Change of habitat structure/morphology

Introduction of non-indigenous species

Translocations of species (native or non-native)

Extraction of flora and/or fauna

Extraction of flora and/or fauna

Death or Injury by Collision

ia GEEN

Thermal changes

Introduction of Non-synthetic compounds

Introduction of Radionuclides

Introduction of Synthetic compounds

Introduction of Non-synthetic compounds

Noise (Underwater and Other)

Noise (Underwater and Other)

Noise (Underwater and Other)

N\&P Enrichment

Changes in input of organic matter

Litter

Disturbance (visual) of species

Water flow rate changes

Changes in wave exposure

Emergence Regime Changes

Changes in Siltation

Barrier to species movement

Changes in Siltation

Tenslotte is hieronder een overzicht gegeven van de activiteiten die zijn genoemd in de Nederlandse KRM beoordeling (Ministerie van I\&W en LNV, 2018) met daarnaast gerelateerde activiteiten zoals opgenomen in de AQUACROSS analyse (Borgwardt et al., 2019). Voor consistentie is de formulering van sommige van de Nederlandse activiteiten aangepast.

Activiteiten NL Noordzee (Ministerie van I\&W en LNV, 2018)

Activiteiten op land: landbouw Activiteiten op land: industrie Activiteiten op land: steden

\section{Activiteiten AQUACROSS (Borgwardt et al., 2019)}

Agriculture (crops and livestock)

Manufacturing: Industry with discharges - operational

Urban dwellings and commercial developments 
Activiteiten op land: waterzuivering

\section{Baggeren}

Kustverdediging

Landaanwinning

Mariene aquacultuur

Mariene aquacultuur (import schelpdieren)

Militaire operaties

Mondiale uitstoot broeikasgassen

Olie- en gasactiviteiten

Onttrekking van mineralen

Scheepvaart

Toerisme en recreatie

Vervoer op land

Vervoersinfrastructuur (havens)

Hengelsport

Visserij: bodemberoerend of demersaal

Visserij: pelagisch

Visserij: staandwant

Visserij: schelpdieren

Waterloopwijzigingen

Windturbines installatie (heien)

Windturbines operationeel

Zandsuppleties

Zandwinning (diep)
Waste management - operational disposal of waste or other material and/or sewage treatment and storm overflows

Dredging (including captial and maintenance, and extraction and disposal of substrate)

Flood and coastal defence - Artificial Structures: including levees, dykes, embankments, sea walls/breakwaters/groynes

Land claim and conversion (including construction and operation)

In-situ aquaculture

In-situ aquaculture

Military

GEEN

Oil and Gas

Mining, extraction of materials: including inorganic, maerl, rock/minerals, sand/gravel, salt

Shipping

Boating/Yachting/Watersports (without engine)

Boating/Yachting/Watersports, including tourist boats (with engine)

Commercial Cruise (large)

Transport (roads, vehicles, other)

Marinas and dock/port facilities

Angling and sport fishing (including catch and release and stocking)

Fishing: Benthic trawling and suction/hydraulic dredges

Fishing: Pelagic trawls and long-line pelagic (including steaming, operations, mooring/anchoring)

Fishing: Nets, potting/creeling (set up/recovery, operations)

Tidal sluices and barrages

Wind farms

Wind farms

Beach replenishment

Mining, extraction of materials: including inorganic, maerl, rock/minerals, sand/gravel, salt 


\section{Bijlage 3 KRM indicatoren: initiële opzet}

Overzicht 32 KRM indicatoren (Ministerie van IenM \& EZ, 2014), inclusief bijbehorende descriptoren

$\mathrm{Nr} \quad$ Indicator

D1 Biodiversiteit: Benthos

1 Geaggregeerde indicatoren voor verspreiding, voorkomen en conditie van representanten van langlevende en voor bodemberoering gevoelige benthische soorten en biogene structuren

D1 Biodiversiteit: Vissen

2 De primaire indicator voor de visserijdruk op commerciële visbestanden is de vissterfte van commercieel gevangen vis (= F). Waar waarden voor $F$ niet beschikbaar zijn, kan de (verandering in) vangst per visserij-inspanningseenheid worden genomen (Catch Per Unit of Effort)

3 De biomassa van de paaibestanden (SSB van commercieel gevangen vis)

$4 \quad$ Grootteverdeling van visbestanden, zowel van commerciële als van kwetsbare soorten. Per soort de 95\%-percentiel van de vislengtedistributie, waargenomen in onderzoeken van researchschepen

5 Geaggregeerde indicatoren voor populatieomvang, verspreiding en conditie van haaien en roggen, vissoorten met een langdurige negatieve trend en trekvissen

6 Discards bij visserij

D1 Biodiversiteit: Vogels

7 Verspreiding, omvang, conditie en toekomstperspectief van populaties kwetsbare vogelsoorten en de kwaliteit van het leefgebied

D1 Biodiversiteit: Zeezoogdieren

8 Verspreiding, omvang en conditie en toekomstperspectief van populaties zeezoogdieren en de kwaliteit van het leefgebied

D1 Biodiversiteit: Demografische kenmerken

9 Relevante indicatoren zijn al onder 'soorten' genoemd

D4 Voedselwebben

10 Aandeel grote vissen in vangsten van bodemsoorten (IBTS): lengte-frequentieverdeling

11 Indicatoren voor zeevogels, zeezoogdieren en haaien en roggen als toppredatoren

12 Voedselrelatie van sleutelsoorten

D6 Habitats

13 Verspreiding en omvang van algemeen voorkomende habitats (EUNIS-niveau 3) en habitats onder de Habitatrichtlijn

14 Zeebodemareaal dat niet wordt verstoord

15 Indices voor de samenstelling van bodemleefgemeenschappen

16 Indicatoren voor de kwaliteit van de verschillende habitats op EUNIS-niveau 3

D2 Niet-inheemse soorten

17 Aantal aanwezige exoten: het aantal aanwezige invasieve exotensoorten

18 Aantal nieuwe exoten: het aantal nieuwe invasieve exotensoorten per jaar

19 Ratio inheems/exoot: de ratio tussen a) dichtheden of biomassa van inheemse soorten voor een selectie van specifieke soortengroepen (fytoplankton, macrobenthos, vis) in Natura 2000-gebieden

D5 Eutrofiëring

20 Nutriënten: Nutriëntenniveaus

21 Directe effecten

22 Indirecte effecten

D7 Hydrografische eigenschappen*

P1 Omvang van het beïnvloede (zeebodem)areaal

P2 Omvang van permanente veranderde habitattypen

P3 Veranderde functies van habitats

D8 Vervuilende stoffen

23 Polaire stoffen in water: concentraties van vervuilende stoffen

24 Apolaire stoffen in biota: concentraties van vervuilende stoffen

25 Imposex en intersex: effecten van TBT (de mate van voorkomen van imposex bij zeeslakken)

26 Olievogels: effecten van olie (het percentage met olie besmeurde aangespoelde vogels) 
Vervuilende stoffen in visproducten voor menselijke consumptie

27 De frequentie van overschrijdingen van de geldende limieten

28 De daadwerkelijke gehalten die zijn gemeten

29 Het aantal vervuilende stoffen waarvoor overschrijdingen tegelijkertijd zijn gemeten

D10 Zwerfvuil

30 De bron van de vervuiling: zwerfvuil

31 Zwerfvuil op het strand: trends in hoeveelheden, samenstelling, verspreiding en bronnen van zwerfvuil aangetroffen op de stranden

32 Plastic in stormvogels: trends in de hoeveelheid en samenstelling van plastics, aangetroffen in de magen van mariene organismen

D11 Onderwatergeluid**

O1 Spreiding in tijd en plaats van luide impulsgeluiden met een lage of middenfrequentie

O2 Ononderbroken geluid met een lage frequentie

*De monitoring voor hydrografische eigenschappen is slechts aan de orde, indien door (grote) ingrepen de hydrografische eigenschappen

veranderen en levert geen structurele monitoringinspanning op voor het KRMmonitoringprogramma. In voorkomende gevallen wordt de monitoring afgedekt met projectmonitoring voor deze specifieke ingrepen.

**Daarnaast zijn er in de Mariene Strategie nog twee indicatoren voor onderwatergeluid gedefinieerd, waaraan in een separaat onderzoeksprogramma aandacht wordt besteed. 


\section{Bijlage 4 KRM indicatoren: geactualiseerd}

Dit overzicht is gebaseerd op informatie uit het rapport van het Ministerie van I\&W en LNV (2018).

Descriptor

\begin{tabular}{|c|c|c|c|c|c|c|c|c|c|c|}
\hline Indicator & 1 & 2 & 3 & 4 & 5 & 6 & 8 & 9 & 10 & 11 \\
\hline $\begin{array}{l}\text { Acute verontreinigingen: aantal olielozingen en het volume per } \\
\text { incident (Bonn Agreement). }\end{array}$ & & & & & & & $\mathrm{x}$ & & & \\
\hline Bronnen van zware metalen: OSPAR - Bronnen van zware metalen & & & & & & & $\mathrm{X}$ & & & \\
\hline GVB - FMSY en paaibiomassa. & $\mathrm{X}$ & & $\mathrm{X}$ & & & & & & & \\
\hline ICES/NLD6 - Visserijdrukindicator. & & & & & & $\mathrm{X}$ & & & & \\
\hline $\begin{array}{l}\text { Kustwateren: NL - KRW specifiek verontreinigende stoffen in de 1- } \\
\text { mijlszone en prioritaire stoffen in de } 12 \text {-mijlszone. }\end{array}$ & & & & & & & $\mathrm{x}$ & & & \\
\hline Kustwateren: OSPAR D8C2 Imposex. & & & & & & & $\mathrm{X}$ & & & \\
\hline $\mathrm{NL}$ - Benthische Indicator Soorten Index (BISI) & & & & & & $\mathrm{X}$ & & & & \\
\hline NL - Beoordeling volgens EG1881/2006 & & & & & & & & $\mathrm{X}$ & & \\
\hline NL - D6 Spreiding en ruimtelijke omvang fysiek verlies. & & & & & & $\mathrm{X}$ & & & & \\
\hline NL - HR Beoordeling grijze en gewone zeehond en bruinvis. & $\mathrm{X}$ & & & & & & & & & \\
\hline $\mathrm{NL}-\mathrm{HR}$ beoordeling $\mathrm{H} 1110$ en $\mathrm{H} 1170$ & & & & & & $\mathrm{X}$ & & & & \\
\hline $\mathrm{NL}$ - HR Beoordeling trekvissen & $\mathrm{X}$ & & & & & & & & & \\
\hline $\mathrm{NL}$ - KRW Vismigratieknelpunten & $\mathrm{X}$ & & & & & & & & & \\
\hline $\mathrm{NL}-$ KRW-beoordeling & & & & & $\mathrm{X}$ & & & & & \\
\hline NL - VR Beoordeling vogels. & $\mathrm{X}$ & & & & & & & & & \\
\hline Offshore wateren: OSPAR - metalen in biota en sediment & & & & & & & $\mathrm{X}$ & & & \\
\hline Offshore wateren: OSPAR - organotin in sediment & & & & & & & $\mathrm{X}$ & & & \\
\hline Offshore wateren: OSPAR - PAK's in biota en sediment & & & & & & & $\mathrm{X}$ & & & \\
\hline Offshore wateren: OSPAR - PBDE's in biota en sediment & & & & & & & $\mathrm{X}$ & & & \\
\hline Offshore wateren: OSPAR - PCB's in biota en sediment & & & & & & & $\mathrm{X}$ & & & \\
\hline OSPAR - Abundantie en verspreiding walvisachtigen & & & & & & & & & & $\mathrm{X}$ \\
\hline OSPAR - Abundantie zeevogels (Marine Bird Abundance) & $\mathrm{X}$ & & & & & & & & & \\
\hline $\begin{array}{l}\text { OSPAR - Broedsucces of broedfalen zeevogels (Marine Bird breeding } \\
\text { success or failure) }\end{array}$ & $\mathrm{x}$ & & & & & & & & & \\
\hline OSPAR - Bruinvisbijvangst (M6) & $\mathrm{X}$ & & & & & & & & & \\
\hline OSPAR - Conditie van benthische gemeenschappen (MMI) & & & & & & $\mathrm{X}$ & & & & \\
\hline OSPAR - FC1 Herstel van populaties van gevoelige soorten & $\mathrm{X}$ & & & & & & & & & \\
\hline OSPAR - FC2 Aandeel grote vissen in visgemeenschappen & $\mathrm{X}$ & & & & & & & & & \\
\hline OSPAR - FW3 Grootteverdeling in visgemeenschappen & & & & $\mathrm{X}$ & & & & & & \\
\hline OSPAR - Impulsgeluid & $\mathrm{X}$ & & & & & & & & & $\mathrm{X}$ \\
\hline OSPAR - Plastic in zeevogelmagen & & & & & & & & & $\mathrm{x}$ & \\
\hline OSPAR - Pupaanwas grijze zeehond (M5) & $\mathrm{X}$ & & & & & & & & & \\
\hline OSPAR - Strandafval & & & & & & & & & $\mathrm{X}$ & \\
\hline $\begin{array}{l}\text { OSPAR - Trends in nieuwe gegevens over niet-inheemse soorten } \\
\text { (NIS) die zijn geïntroduceerd door menselijke activiteiten. }\end{array}$ & & $\mathrm{x}$ & & & & & & & & \\
\hline OSPAR - Walvisachtigen abundantie en verspreiding (M4-B) & $\mathrm{X}$ & & & & & & & & & \\
\hline OSPAR - Zeebodemafval & & & & & & & & & $\mathrm{X}$ & \\
\hline OSPAR - Zeehonden abundantie en verspreiding (M3) & $\mathrm{X}$ & & & & & & & & & \\
\hline OSPAR Chlorofylconcentraties & & & & & $\mathrm{X}$ & & & & & \\
\hline $\begin{array}{l}\text { OSPAR Common Procedure for identification of the eutrophication } \\
\text { status of the OSPAR maritime area (COMP) }\end{array}$ & & & & & $\mathrm{x}$ & & & & & \\
\hline OSPAR Nutriëntconcentraties & & & & & $\mathrm{X}$ & & & & & \\
\hline OSPAR Opgeloste zuurstofconcentraties & & & & & $\mathrm{X}$ & & & & & \\
\hline $\begin{array}{l}\text { OSPAR PH1/FW5 - Veranderingen in fytoplankton- en } \\
\text { zoöplanktongemeenschappen. }\end{array}$ & $\mathrm{X}$ & & & & & & & & & \\
\hline $\begin{array}{l}\text { OSPAR PH } 2 \text { - Veranderingen in biomassa van fytoplankton en } \\
\text { abundantie van zoöplankton }\end{array}$ & $\mathrm{x}$ & & & & & & & & & \\
\hline OSPAR Toevoer van nutriënten & & & & & $x$ & & & & & \\
\hline
\end{tabular}




\section{Bijlage 5 KRM indicatoren: parameters en drempelwaarden}

Bron: Ministerie van Infrastructuur en Waterstaat \& Ministerie van Landbouw, Natuur en Voedselkwaliteit (2018): Mariene Strategie (deel 1). Actualisatie van huidige milieutoestand, goede milieutoestand, milieudoelen en indicatoren. 2018-2024. Juni 2018. Te downloaden via: https://www.rijksoverheid.nl/regering/bewindspersonen/cora-vannieuwenhuizen/documenten/rapporten/2018/06/21/bijlage-5-mariene-strategie

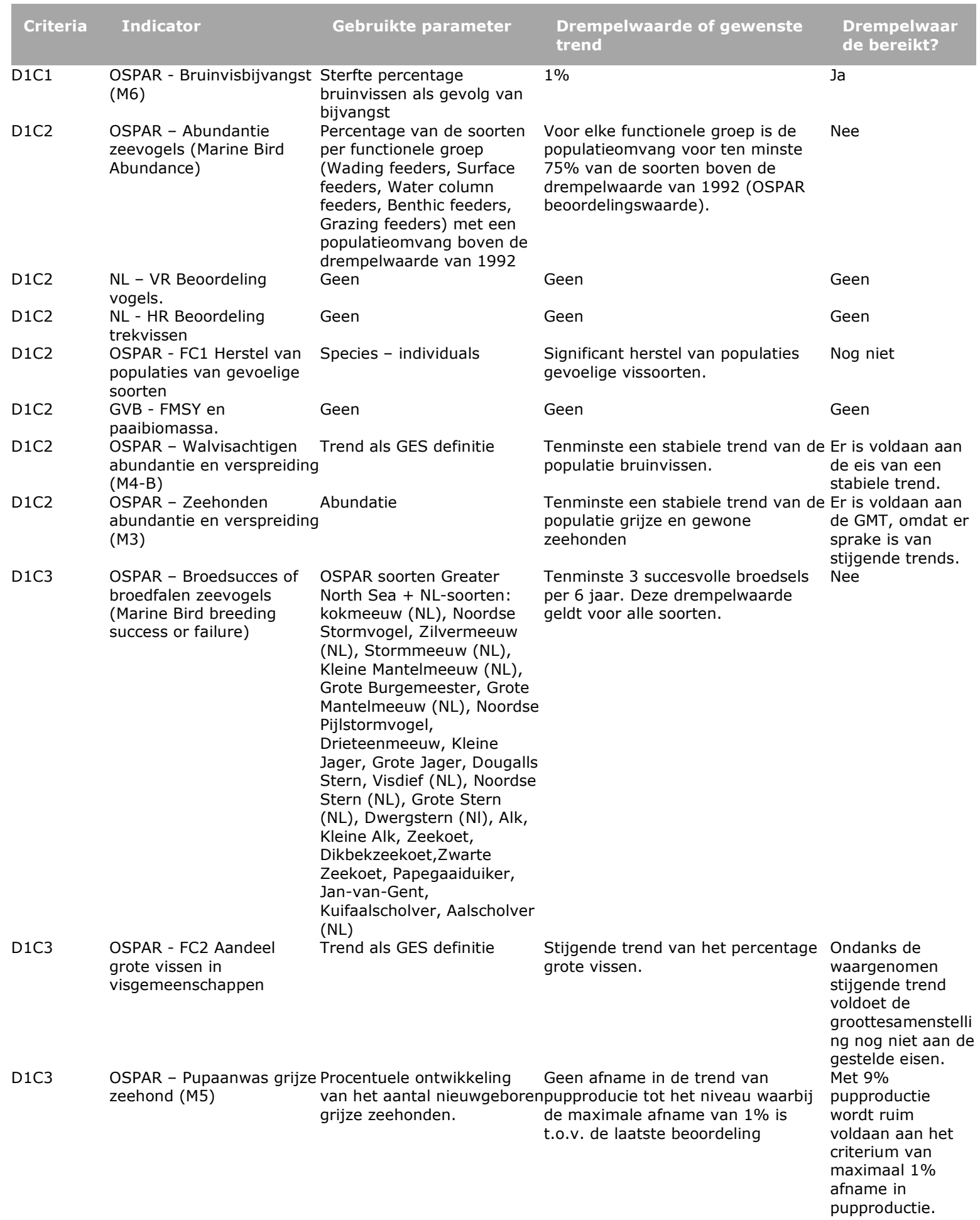




\begin{tabular}{|c|c|c|c|c|}
\hline Criteria & Indicator & Gebruikte parameter & $\begin{array}{l}\text { Drempelwaarde of gewenste } \\
\text { trend }\end{array}$ & $\begin{array}{l}\text { Drempelwaar } \\
\text { de bereikt? }\end{array}$ \\
\hline D1C4 & $\begin{array}{l}\mathrm{NL}-\mathrm{HR} \text { Beoordeling } \\
\text { trekvissen }\end{array}$ & Geen & Geen & Geen \\
\hline D1C4 & $\begin{array}{l}\text { OSPAR - Zeehonden } \\
\text { abundantie en verspreiding } \\
\text { (M3) }\end{array}$ & Geen & Geen & Geen \\
\hline D1C4 & $\begin{array}{l}\text { OSPAR - Walvisachtigen } \\
\text { abundantie en verspreiding } \\
\text { (M4-B) }\end{array}$ & Geen & Geen & Geen \\
\hline D1C5 & $\begin{array}{l}\mathrm{NL}-\mathrm{KRW} \\
\text { Vismigratieknelpunten }\end{array}$ & Geen & Geen & Geen \\
\hline D1C5 & $\begin{array}{l}\mathrm{NL}-\mathrm{HR} \text { - Beoordeling } \\
\text { grijze en gewone zeehond } \\
\text { en bruinvis. }\end{array}$ & Geen & Geen & Geen \\
\hline D1C6 & $\begin{array}{l}\text { OSPAR PH1/FW5 - } \\
\text { Veranderingen in } \\
\text { fytoplankton- en } \\
\text { zoöplanktongemeenschapp } \\
\text { en. }\end{array}$ & $\begin{array}{l}\text { Holoplankton versus } \\
\text { meroplankton, diatoms } \\
\text { versus dinoflagelates en } \\
\text { small copepods versus large } \\
\text { copepods }\end{array}$ & $\begin{array}{l}\text { De NL Noordzee bestaat uit } \\
\text { verschillende planktonhabitats } \\
\text { (ecohydrodynamic zones). Voor elke } \\
\text { zone is voor zover mogelijk een } \\
\text { index uitgerekend, maar die zones } \\
\text { houden niet op bij de zeegrens. } \\
\text { Verder geldt dat de indicator nog } \\
\text { niet af is, resultaten kunnen nog niet } \\
\text { geïnterpreteerd worden, aldus de } \\
\text { tekst van OSPAR. }\end{array}$ & Nog niet bekend \\
\hline D1C6 & $\begin{array}{l}\text { OSPAR PH2 - } \\
\text { Veranderingen in biomassa } \\
\text { van fytoplankton en } \\
\text { abundantie van } \\
\text { zoöplankton }\end{array}$ & $\begin{array}{l}\text { Biomassa van fytoplankton } \\
\text { en abundantie van } \\
\text { zoöplankton }\end{array}$ & $\begin{array}{l}\text { Er zijn nog geen drempelwaarden } \\
\text { vastgesteld }\end{array}$ & Nog niet bekend \\
\hline $\mathrm{D} 2 \mathrm{C} 1$ & $\begin{array}{l}\text { OSPAR - Trends in nieuwe } \\
\text { gegevens over niet- } \\
\text { inheemse soorten (NIS) } \\
\text { die zijn geïntroduceerd } \\
\text { door menselijke } \\
\text { activiteiten. }\end{array}$ & Geen & Geen & Geen \\
\hline $\mathrm{D} 2 \mathrm{C} 1$ & $\begin{array}{l}\text { D2: Periodiek overzicht } \\
\text { van vastgestelde niet- } \\
\text { inheemse soorten van het } \\
\text { Nederlandse deel van de } \\
\text { Noordzee en hun } \\
\text { transportvectoren; op } \\
\text { basis van de best } \\
\text { beschikbare kennis. }\end{array}$ & Aanwezigheid & $\begin{array}{l}\text { dalende trend in het aantal nieuwe } \\
\text { introducties }\end{array}$ & Ja \\
\hline D3C1 & $\begin{array}{l}\text { GVB - FMSY en } \\
\text { paaibiomassa. }\end{array}$ & $\begin{array}{l}\text { Aantal visbestanden } \\
\text { waarvan visserijsterfte } \\
\text { F<F }\end{array}$ & $\begin{array}{l}100 \% \text { (Voor alle soorten moeten } \\
\text { beide criteria, dus zowel de sterfte } \\
\text { door visserij als de paaibiomassa } \\
\text { van commerciële bestanden, in de } \\
\text { goede milieutoestand verkeren) }\end{array}$ & $\begin{array}{l}\text { Nee (momenteel } \\
26 \% \text { ) }\end{array}$ \\
\hline D3C2 & $\begin{array}{l}\text { GVB - FMSY en } \\
\text { paaibiomassa. }\end{array}$ & $\begin{array}{l}\text { Aantal visbestanden } \\
\text { waarvan paaibiomassa (ton) } \\
>\text { MSY }\end{array}$ & $\begin{array}{l}100 \% \text { (Voor alle soorten moeten } \\
\text { beide criteria, dus zowel de sterfte } \\
\text { door visserij als de paaibiomassa } \\
\text { van commerciële bestanden, in de } \\
\text { goede milieutoestand verkeren) }\end{array}$ & $\begin{array}{l}\text { Nee (momenteel } \\
26 \%)\end{array}$ \\
\hline D4C1 & Geen & Geen & Geen & Geen \\
\hline D4C2 & Geen & Geen & Geen & Geen \\
\hline D4C3 & $\begin{array}{l}\text { OSPAR - FW3 } \\
\text { Grootteverdeling in } \\
\text { visgemeenschappen }\end{array}$ & Typical Length (TyL) & Onbekend & $\begin{array}{l}\text { Niet van } \\
\text { toepassing }\end{array}$ \\
\hline $\begin{array}{l}\text { D5C1 } \\
\text { (kustwatere } \\
\text { n) }\end{array}$ & NL - KRW-beoordeling & Concentratie in water & $\begin{array}{l}\text { DIN KRW kustwater: } 0,46 \mathrm{mg} \mathrm{N} / \mathrm{l} \\
\text { DIN (OSPAR kustzone): } 30 \mu \mathrm{mol} / \mathrm{l} \\
\text { DIP (OSPAR kustzone): } 0,8 \mu \mathrm{mol} / \mathrm{l} \text {. }\end{array}$ & $\begin{array}{l}\text { DIN KRW } \\
\text { kustwater: nee } \\
\text { DIN (OSPAR } \\
\text { kustzone): nee } \\
\text { DIP (OSPAR } \\
\text { kustzone): nee }\end{array}$ \\
\hline $\begin{array}{l}\text { D5C1 } \\
\text { (kustwatere } \\
\text { n) }\end{array}$ & $\begin{array}{l}\text { OSPAR } \\
\text { Nutriëntconcentraties }\end{array}$ & Concentratie in water & $\begin{array}{l}\text { DIN KRW kustwater: } 0,46 \mathrm{mg} \mathrm{N} / \mathrm{l} \\
\text { DIN (OSPAR kustzone): } 30 \mu \mathrm{mol} / \mathrm{l} \\
\text { DIP (OSPAR kustzone): } 0,8 \mu \mathrm{mol} / \mathrm{l} \text {. }\end{array}$ & $\begin{array}{l}\text { DIN KRW } \\
\text { kustwater: nee } \\
\text { DIN (OSPAR } \\
\text { kustzone): nee } \\
\text { DIP (OSPAR } \\
\text { kustzone): nee }\end{array}$ \\
\hline $\begin{array}{l}\text { D5C1 } \\
\text { (offshore } \\
\text { wateren) }\end{array}$ & $\begin{array}{l}\text { OSPAR } \\
\text { Nutriëntconcentraties }\end{array}$ & Concentratie in water & $\begin{array}{l}\text { DIN (buiten OSPAR kustzone): } 15 \\
\mu \text { mol/I DIP (buiten OSPAR } \\
\text { kustzone): } 0,8 \mu \mathrm{mol} / \mathrm{l} \text {. }\end{array}$ & $\begin{array}{l}\text { DIN (buiten } \\
\text { OSPAR kustzone): } \\
\text { ja DIP (buiten } \\
\text { OSPAR kustzone): } \\
\text { ja }\end{array}$ \\
\hline $\begin{array}{l}\text { D5C2 } \\
\text { (kustwatere } \\
\text { n) }\end{array}$ & $\begin{array}{l}\text { OSPAR } \\
\text { Chlorofylconcentraties }\end{array}$ & Concentratie in water & $\begin{array}{l}\text { Niet hoger dan } 50 \text { procent boven } \\
\text { achtergrondwaarde conform de } \\
\text { doelen van de OSPAR COMP, 2,25 } \\
\mu \mathrm{g} / \mathrm{l} \text {. }\end{array}$ & $\mathrm{Ja}$ \\
\hline $\begin{array}{l}\text { D5C2 } \\
\text { (offshore } \\
\text { wateren) }\end{array}$ & $\begin{array}{l}\text { OSPAR } \\
\text { Chlorofylconcentraties }\end{array}$ & Concentratie in water & $\begin{array}{l}\text { Niet hoger dan } 50 \text { procent boven } \\
\text { achtergrondwaarde conform de } \\
\text { doelen van de OSPAR COMP, 2,25 } \\
\mu \mathrm{g} / \mathrm{l} \text {. }\end{array}$ & Ja \\
\hline
\end{tabular}




\begin{tabular}{|c|c|c|c|c|}
\hline Criteria & Indicator & Gebruikte parameter & $\begin{array}{l}\text { Drempelwaarde of gewenste } \\
\text { trend }\end{array}$ & $\begin{array}{l}\text { Drempelwaar } \\
\text { de bereikt? }\end{array}$ \\
\hline $\begin{array}{l}\text { D5C2 } \\
\text { (kustwatere } \\
\text { n) }\end{array}$ & $\mathrm{NL}$ - KRW-beoordeling & Concentratie in water & \multicolumn{2}{|l|}{$\begin{array}{l}6,7 \mu \mathrm{g} / \mathrm{I} \text { of } 9,3 \mu \mathrm{g} / \mathrm{I} \text { (afhankelijk van Ja } \\
\text { het kustwatertype). }\end{array}$} \\
\hline $\begin{array}{l}\text { D5C5 } \\
\text { (kustwatere } \\
\text { n) }\end{array}$ & $\mathrm{NL}$ - KRW-beoordeling & Concentratie in water & \multicolumn{2}{|l|}{$\begin{array}{l}\text { In dit geval een TV lower (niet onder Ja } \\
\text { deze waarde komen) } 60 \% \text { zuurstof } \\
\text { verzadigd. }\end{array}$} \\
\hline $\begin{array}{l}\text { D5C5 } \\
\text { (kustwatere } \\
\text { n) }\end{array}$ & $\begin{array}{l}\text { OSPAR Opgeloste } \\
\text { zuurstofconcentraties }\end{array}$ & Concentratie in water & \multicolumn{2}{|l|}{$\begin{array}{l}\text { In dit geval een TV lower (niet onder Ja } \\
\text { deze waarde komen) } 6 \mathrm{mg} / \mathrm{l} \\
\text { zuurstof. }\end{array}$} \\
\hline $\begin{array}{l}\text { D5C5 } \\
\text { (offshore } \\
\text { wateren) }\end{array}$ & $\begin{array}{l}\text { OSPAR Opgeloste } \\
\text { zuurstofconcentraties }\end{array}$ & Concentratie in water & \multicolumn{2}{|l|}{$\begin{array}{l}\text { In dit geval een TV lower (niet onder Ja } \\
\text { deze waarde komen) } 6 \mathrm{mg} / \mathrm{l} \\
\text { zuurstof. }\end{array}$} \\
\hline $\mathrm{D} 6 \mathrm{C} 1$ & $\begin{array}{l}\mathrm{NL} \text { - D6 - Spreiding en } \\
\text { ruimtelijke omvang fysiek } \\
\text { verlies. }\end{array}$ & Oppervlakte & Niet vastgesteld & $\begin{array}{l}\text { Niet van } \\
\text { toepassing }\end{array}$ \\
\hline D6C2 & $\begin{array}{l}\text { ICES/NLD6 - } \\
\text { Visserijdrukindicator. }\end{array}$ & \multicolumn{2}{|c|}{$\begin{array}{l}\text { Visserijdruk en de impact op Nog niet vastgesteld } \\
\text { de zeebodem }\end{array}$} & Onbekend \\
\hline D6C3 & $\begin{array}{l}\text { NL - Benthische Indicator } \\
\text { Soorten Index (BISI) }\end{array}$ & Trend als GMT definitie & $\begin{array}{l}\text { De kwaliteit van de beoordeelde } \\
\text { gebieden en habitats op het } \\
\text { Nederlandse deel van de Noordzee } \\
\text { (Benthische Indicator Soorten } \\
\text { Index) neemt toe (stijgende trend } \\
+1) \text {. HabBenCircalitCoarSed - } \\
\text { kwaliteit moet toenemen }(+1) \\
\text { HabBenCircalitSand - kwaliteit moet } \\
\text { toenemen }(+1) \text { HabBenCircalitMud - } \\
\text { kwaliteit moet toenemen }(+1) \\
\text { HabBenOffshCoarSed - kwaliteit } \\
\text { moet toenemen }(+1) \\
\text { HabBenOffshSand - kwaliteit moet } \\
\text { toenemen }(+1) \text { HabBenOffshMud - } \\
\text { kwaliteit moet toenemen (+1) } \\
\text { H1110b - kwaliteit moet toenemen } \\
(+1) \text { H1110c - kwaliteit moet } \\
\text { toenemen }(+1) \text { H1170 - kwaliteit } \\
\text { moet toenemen }(+1)\end{array}$ & Nog niet bekend \\
\hline D6C3 & $\begin{array}{l}\text { ICES/NLD6 - } \\
\text { Visserijdrukindicator. }\end{array}$ & $\begin{array}{l}\text { Visserijdruk en de impact op } \\
\text { de zeebodem }\end{array}$ & Nog niet vastgesteld & Onbekend \\
\hline D6C3 & $\begin{array}{l}\mathrm{NL}-\mathrm{HR} \text { beoordeling } \\
\mathrm{H} 1110 \text { en } \mathrm{H} 1170\end{array}$ & Geen & Geen & Geen \\
\hline D6C4 & $\begin{array}{l}\mathrm{NL} \text { - D6 - Spreiding en } \\
\text { ruimtelijke omvang fysiek } \\
\text { verlies. }\end{array}$ & Oppervlakte & Geen drempelwaarde vastgesteld & Onbekend \\
\hline D6C5 & $\begin{array}{l}\text { OSPAR - Conditie van } \\
\text { benthische } \\
\text { gemeenschappen (MMI) }\end{array}$ & $\begin{array}{l}\text { Margelef index } \\
\text { (soortenrijkdom } \\
\text { gecorrigeerd voor totale } \\
\text { abundantie) }\end{array}$ & Nog niet vastgesteld & Niet bekend \\
\hline D7C1 & Geen & Geen & Geen & Geen \\
\hline D7C2 & Geen & Geen & Geen & Geen \\
\hline $\mathrm{D} 8 \mathrm{C} 1$ & $\begin{array}{l}\text { Kustwateren: NL - KRW } \\
\text { specifiek verontreinigende } \\
\text { stoffen in de } 1 \text {-mijlszone } \\
\text { en prioritaire stoffen in de } \\
12 \text {-mijlszone. }\end{array}$ & Geen & Geen & Geen \\
\hline $\mathrm{D} 8 \mathrm{C} 1$ & $\begin{array}{l}\text { Offshore wateren: OSPAR } \\
\text { - PAK's in biota en } \\
\text { sediment }\end{array}$ & $\begin{array}{l}\text { Concentratie in biota }(\mu \mathrm{g} / \mathrm{kg} \\
\text { natgewicht) }\end{array}$ & $\begin{array}{l}\text { Zuidelijke Noordzee gewenste trend: } \\
\text { dalend (Naphthaleen, fenantreen, } \\
\text { anthracene, fluorantheen, pyreen, } \\
\text { benzo[a]anthracene, chrysene, } \\
\text { benzo[a]pyreen, } \\
\text { benzo[g,h,i]peryleen, indeno[123- } \\
\text { c,d]pyreen) }\end{array}$ & Geen \\
\hline $\mathrm{D} 8 \mathrm{C} 1$ & $\begin{array}{l}\text { Offshore wateren: OSPAR } \\
\text { - PCB's in biota en } \\
\text { sediment }\end{array}$ & $\begin{array}{l}\text { Concentratie in biota }(\mu \mathrm{g} / \mathrm{kg} \\
\text { natgewicht) }\end{array}$ & $\begin{array}{l}\text { Zuidelijke Noordzee gewenste trend: } \\
\text { dalend (CB 28;52;101; 118; } 138 ; \\
158 ; 180)\end{array}$ & Geen \\
\hline $\mathrm{D} 8 \mathrm{C} 1$ & $\begin{array}{l}\text { Offshore wateren: OSPAR } \\
\text { - PBDE's in biota en } \\
\text { sediment }\end{array}$ & $\begin{array}{l}\text { Concentratie in biota }(\mu \mathrm{g} / \mathrm{kg} \\
\text { natgewicht) }\end{array}$ & $\begin{array}{l}\text { Zuidelijke Noordzee gewenste trend: } \\
\text { dalend (BDE 28;47;99;100;153) }\end{array}$ & Geen \\
\hline $\mathrm{D} 8 \mathrm{C} 1$ & $\begin{array}{l}\text { Offshore wateren: OSPAR - } \\
\text { organotin in sediment }\end{array}$ & $\begin{array}{l}\text {-Concentratie in sediment } \\
(\mu \mathrm{g} / \mathrm{kg})\end{array}$ & $\begin{array}{l}\text { Zuidelijke Noordzee gewenste trend: } \\
\text { dalend (Monobutyltin, dibutyltin, } \\
\text { tributyltin) }\end{array}$ & \\
\hline $\mathrm{D} 8 \mathrm{C} 1$ & $\begin{array}{l}\text { Offshore wateren: OSPAR - } \\
\text { metalen in biota en } \\
\text { sediment }\end{array}$ & $\begin{array}{l}\text { - Concentratie in biota }(\mu \mathrm{g} / \mathrm{kg} \\
\text { natgewicht) }\end{array}$ & $\begin{array}{l}\text { Zuidelijke Noordzee gewenste trend: } \\
\text { dalend (Cadmium, Kwik, Lood); niet } \\
\text { van toepassing (Koper, Zink) }\end{array}$ & Geen \\
\hline $\mathrm{D} 8 \mathrm{C} 1$ & $\begin{array}{l}\text { Bronnen van zware } \\
\text { metalen: OSPAR - Bronnen } \\
\text { van zware metalen }\end{array}$ & Geen & Geen & Geen \\
\hline $\mathrm{D} 8 \mathrm{C} 1$ & $\begin{array}{l}\text { NL-koperconcentraties: } \\
\text { koperconcentraties zijn } \\
\text { nog niet opgenomen in het } \\
\text { KRMmonitoringprogramma } \\
\text {. Naar verwachting zal dit } \\
\text { uiterlijk in } 2020 \text { gebeuren. }\end{array}$ & Geen & Geen & Geen \\
\hline
\end{tabular}




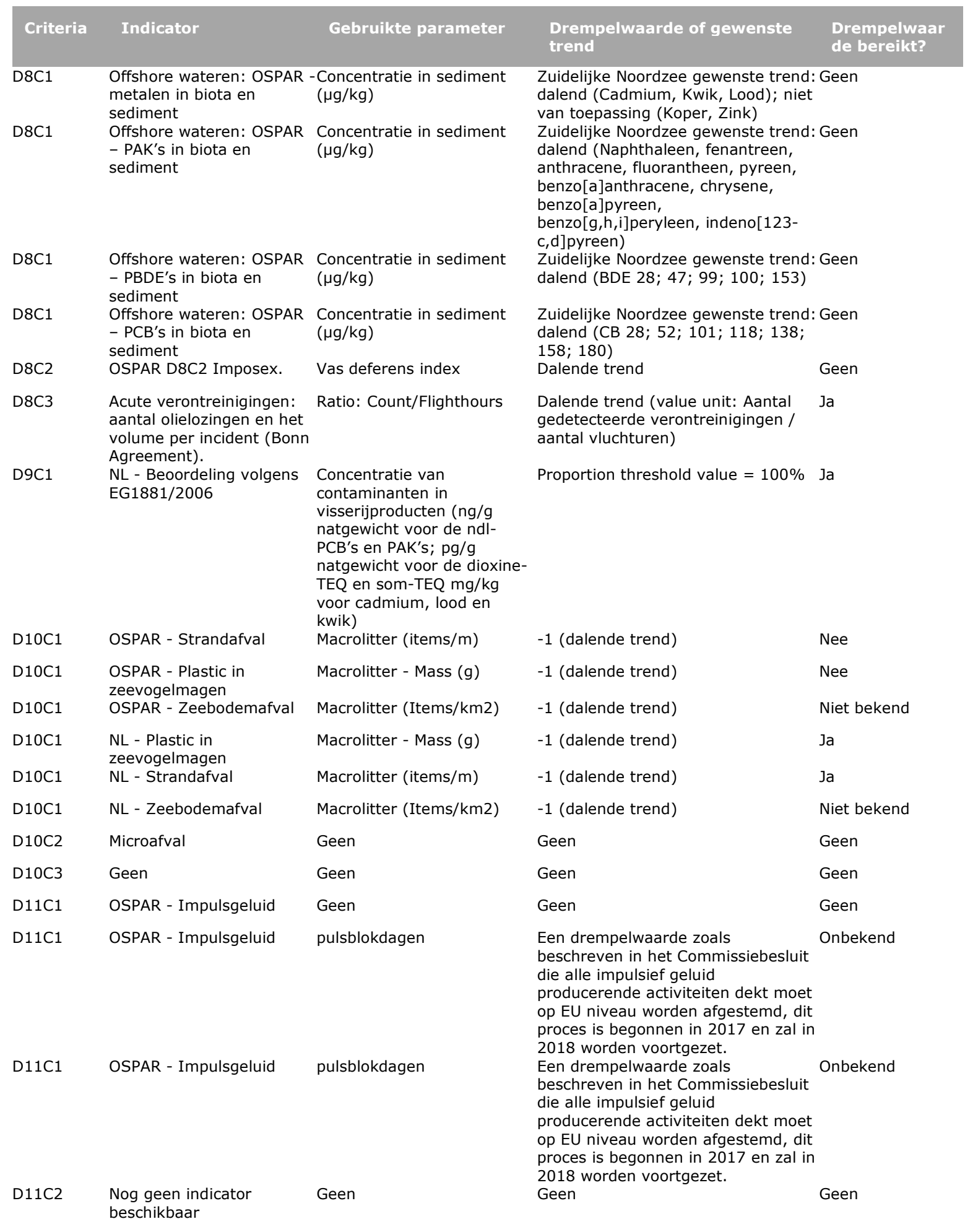




\section{Bijlage 6 Habitatrichtlijnsoorten}

Overzicht van soorten die genoemd zijn in bijlage II, IV en/of V van de Habitatrichtlijn en die na 1900 in het wild in Nederland zijn waargenomen

(http://minez.nederlandsesoorten.nl/content/habitatrichtlijn). Met uitzondering van een aantal vleermuissoorten* zijn alleen de mariene soorten hier weergegeven, inclusief het voorkomen in de Nederlandse Noordzee (de status volgens het Nederlands soortregister van het ministerie van EZ (http://minez.nederlandsesoorten.nl/soorten), uitgezonderd vleermuissoorten)

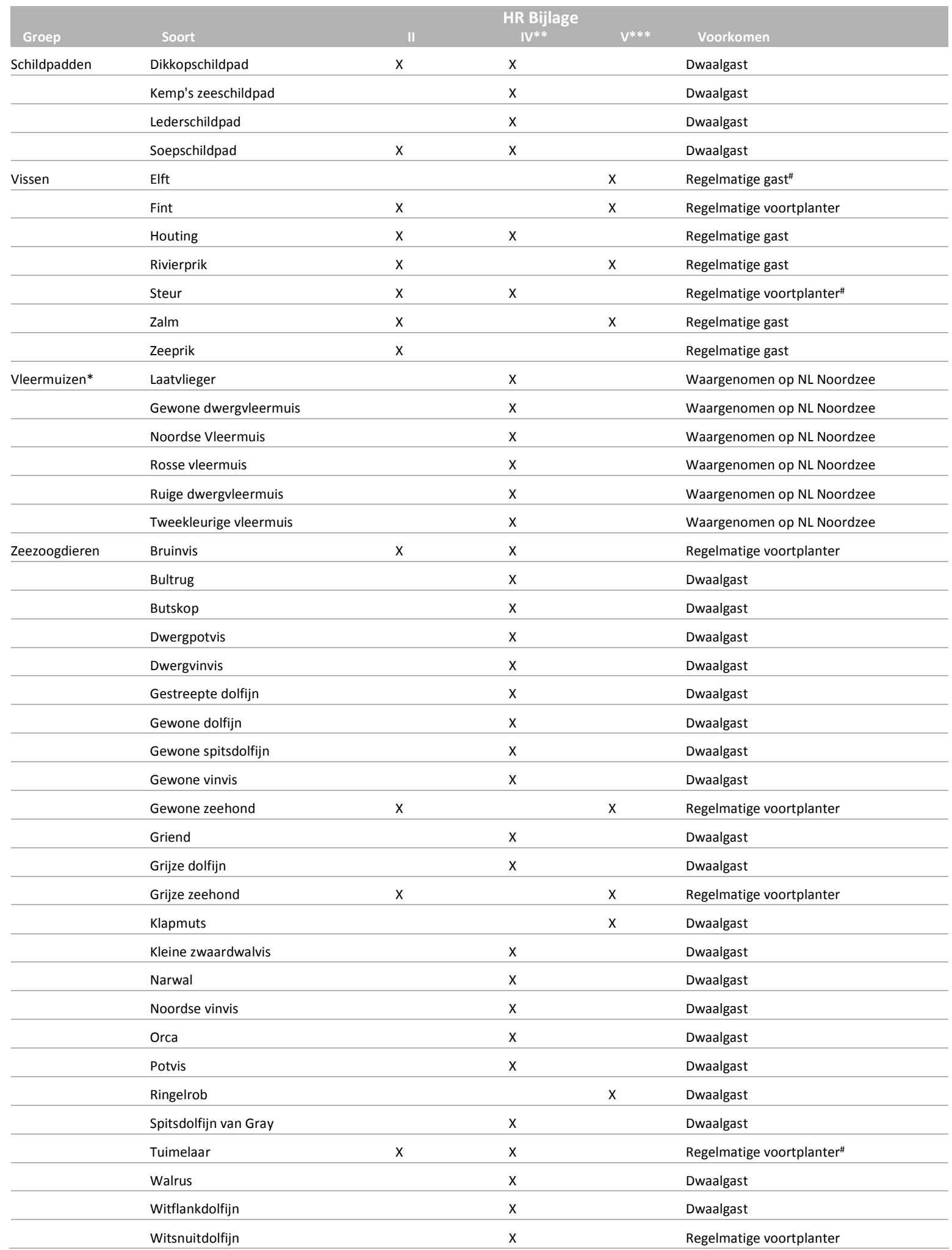




\begin{tabular}{lllll}
\hline & & & \\
Soort & HR Bijlage & & \\
Groep & Witte dolfijn & $\mathrm{X}$ & Voorkomen \\
\hline Zadelrob & & $\mathrm{X}$ & Dwaalgast \\
\hline
\end{tabular}

*Voor wat betreft vleermuizen zijn alleen de soorten weergegeven die zijn waargenomen op de Nederlandse Noordzee, op basis van Leopold et al. (2014); ** incl. Bern annex II en Bonn annex I; *** incl. Bern annex III en Bonn annex II ; \#Status ter discussie 


\section{Bijlage 7 OSPAR biodiversity indicators}

Bron: https://www.ospar.org/work-areas/bdc/biodiversity-monitoring-assessment-1/biodiversitycommon-indicators

$\begin{array}{lll}\text { Code } & \text { Common indicator name } & \text { Common in } \\ & & \begin{array}{l}\text { OSPAR } \\ \text { Region }\end{array} \\ \text { M3 } & \text { Seal Abundance and Distribution } & \text { II } \\ \text { M4 } & \text { Abundance and Distribution of marine mammals } & \text { II, III, IV } \\ \text { M5 } & \text { Grey seal pup production } & \text { II, III } \\ \text { M6 } & \text { Marine mammal bycatch } & \text { II } \\ \text { B1 } & \text { Marine bird abundance } & \text { II, III, IV } \\ \text { B3 } & \text { Marine Bird Breeding Success / Failure } & \text { II, III, IV } \\ \text { FC1 } & \text { Recovery in the population abundance of sensitive fish species } & \text { II, III } \\ \text { FC2 } & \text { Proportion of large fish (Large Fish Index) } & \text { II, III } \\ \text { BH1 } & \text { Typical species composition } & \text { IV } \\ \text { BH2 } & \text { Condition of Benthic Habitat Communities } & \text { II, III, IV } \\ \text { BH3 } & \text { Extent of Physical Damage to Predominant and Special Habitats } & \text { II, III, IV } \\ \text { PH1/FW5 } & \text { Changes in plankton functional types (life form) index Ratio } & \text { II, III, IV } \\ \text { PH2 } & \text { Plankton biomass and/or abundance } & \text { II, III, IV } \\ \text { PH3 } & \text { Changes in biodiversity index(s) } & \text { III } \\ \text { NIS } & \text { Trends in New Records of Non-Indigenous Species (NIS) Introduced by } & \text { II, III, IV } \\ & \text { Human Activities } & \end{array}$




\section{Bijlage 8 Bow tie analyses}

Bron:

Cormier, R., Elliott, M., and Kannen, A. (2018). IEC/ISO Bow-tie analysis of marine legislation: A case study of the Marine Strategy Framework Directive. ICES Cooperative Research Report No. 342. 56 pp. https://doi.org/10.17895/ices.pub.4504

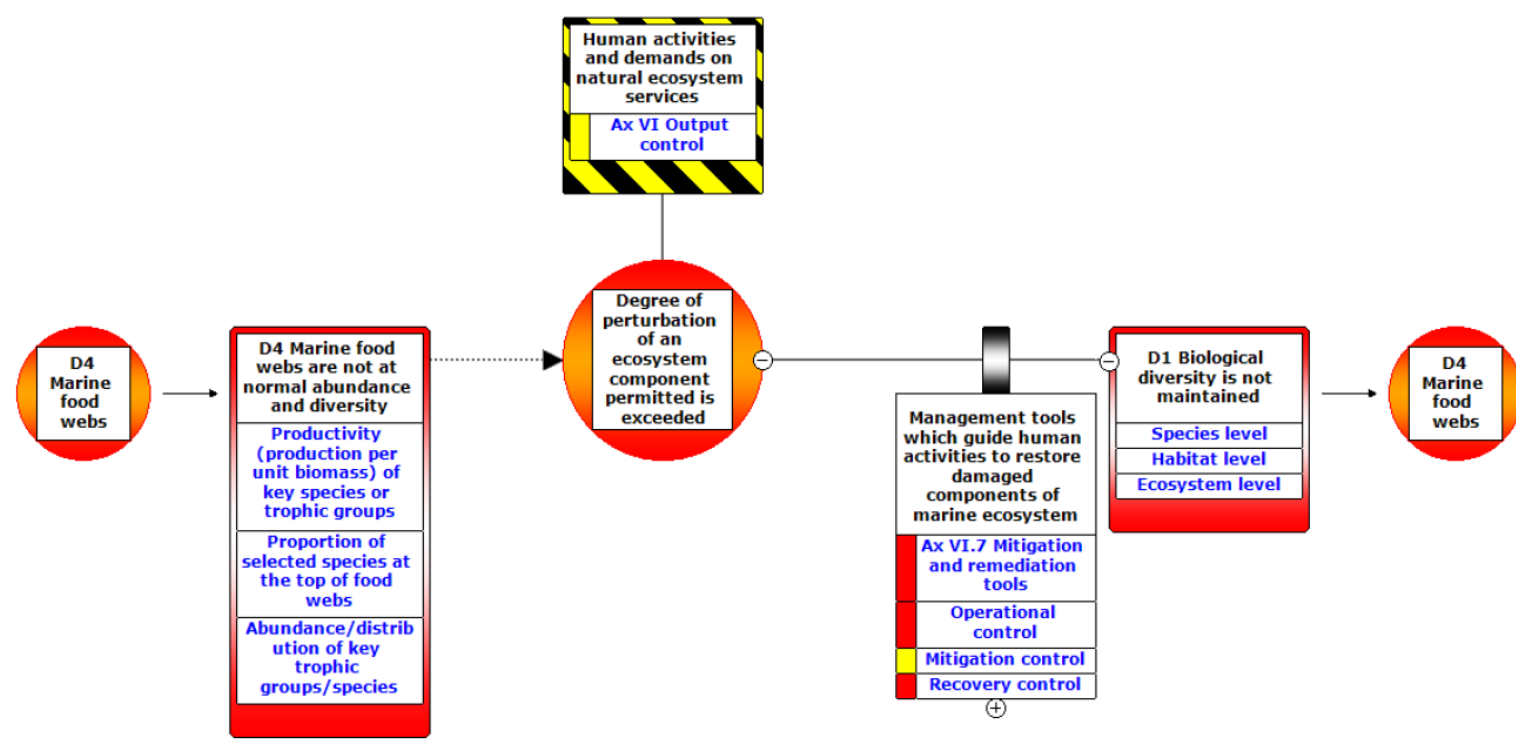

Bow-tie analyse van D1: Biodiversiteit (Cornier et al., 2018). 
Wageningen Marine Research

T: $+31(0) 317480900$

E: marine-research@wur.nl

www.wur.nl/marine-research

Bezoekers adres:

- Ankerpark 271781 AG Den Helder

- Korringaweg 7, 4401 NT Yerseke

- Haringkade 1, 1976 CP IJmuiden
Wageningen Marine Research levert met kennis, onafhankelijk wetenschappelijk onderzoek en advies een wezenlijke bijdrage aan een duurzamer, zorgvuldiger beheer, gebruik en bescherming van de natuurlijke rijkdommen in zee-, kust- en zoetwatergebieden.
Wageningen Marine Research is onderdeel van Wageningen University \& Research. Wageningen University \& Research is het samenwerkingsverband tussen Wageningen University en Stichting Wageningen Research en heeft als missie: 'To explore the potential of nature to improve the quality of life' 